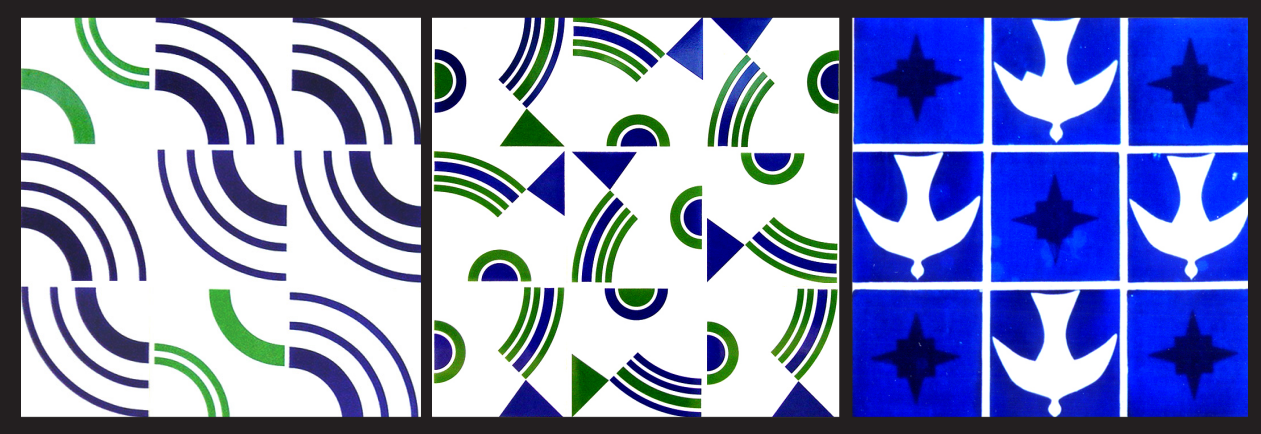

azulejo na arquitetura brasileira os painéis de athos bulcão ingrid moura wanderley eesc-usp 2006 
UNIVERSIDADE DE SÃO PAULO ESCOLA DE ENGENHARIA DE SÃO CARLOS

DEPARTAMENTO DE ARQUITETURA E URBANISMO DISSERTAÇÃO DE MESTRADO

\section{azulejo na arquitetura brasileira os painéis de athos bulcão}

INGRID MOURA WANDERLEY ORIENTADOR PROF. DR. EDUVALDO P. SICHIERI

Agosto, 2006 


\section{agradecimentos}

Aos meus avós Moura (in memoriam) e Vasinha, por existirem;

Aos meus pais Geraldo e Astrid, pelos valores e pelo apoio na realização dos meus projetos;

Ao meu irmão Carlos Eduardo e minha cunhada Natércia, pela importante acolhida e hospedagem

no primeiro ano em São Paulo;

À Irmã Leonilda do Pensionato Santa Marcelina;

À Lamartine pela ajuda no primeiro projeto de pesquisa;

À Daniela e Felipe que trouxeram tanta alegria;

À toda minha família e amigos de Recife, São Paulo e São Carlos;

Aos professores da FAU/USP Profa. Dra. Maria Cecília, Prof. Dr. Rafael Perrone e Profa. Dra. Elide Monzeglio (in memoriam), pelas primeiras orientações durante as disciplinas que fiz lá;

Aos professores do Departamento de Arquitetura e Urbanismo da Escola de Engenharia de São Carlos, principalmente: ao meu orientador Prof. Dr. Eduvaldo Sichieri, pela liberdade e confiança em mim e no meu trabalho; à Profa. Dra. Telma de Barros pela amizade e pela hospedagem nos primeiros dias em São Carlos; ao Prof. Dr. Fábio Lopes por despertar meu interesse pelo trabalho do Athos Bulcão; à Profa. Dra. Maria Ângela Bortolucci, pelo carinho e pelas orientações que muito contribuíram para a finalização do trabalho;

Aos professores membros da banca de qualificação e defesa da dissertação Prof. Dr. Carlos Roberto Monteiro de Andrade e Profa. Dra. Daici Ceribeli Antunes de Freitas pela minuciosa leitura e valiosas sugestões;

Aos funcionários do Departamento de Arquitetura e Urbanismo e da Biblioteca Central da Escola de Engenharia de São Carlos, Marcelinho, Geraldo, Paulo Ceneviva, Zanardi, Oswaldo, Serginho, Fátima, Lucinda, João e Eleninha;

Aos colegas, pela convivência em São Carlos, principalmente: Carolina Rossetti, Tatiana Sakurai, Mayara Dias, Marina Rahal, Cecília Almeida, Gizela Peralta, Anna Raquel, Luciana Mascaro, Mateus Rosada, Vladimir Benincasa, Renata La Rocca, Clarissa Ribeiro, Thaís Cruz, Luis, Rosana Folz, Ana Paula Costa, Sara Grubert, em especial à Sales Trajano pelas orientações e pelas leituras atentas;

À Petrônio Cunha e Luís Domingues dos Santos, pelas entrevistas;

Às pessoas que encontrei e conheci em Brasília, principalmente Valéria Cabral, Eduardo Cabral, Sérgio Parada, e Haroldo Pinheiro pelas entrevistas, pelo carinho e admiração em falar sobre 0 Athos Bulcão e pelo material concedido;

À Sandrinha, leda e Patrícia, pela amizade e hospedagem em Brasília;

Ao CNPq - Conselho Nacional de Desenvolvimento Científico e Tecnológico, pelo apoio financeiro. 


\section{sumário}

Resumolabstract 4

introdução 5

o azulejo 11

O azulejo e suas origens 11

$\begin{array}{ll}\text { Azulejaria portuguesa e sua introdução no Brasil } & 17\end{array}$

Azulejaria no Brasil - aplicações e evolução $\quad 28$

O azulejo como revestimento cerâmico para fachadas 34

Indústria de revestimentos cerâmicos no Brasil 36

Processos de produção 41

Técnicas de decoração 43

o azulejo na arquitetura moderna brasileira 45

Arte e política no Brasil (1930-1950) 45

O mural, o painel e a síntese das artes 51

O azulejo como elemento de tradição e os modernos 54

Painéis do MES e a Osiarte 63

Azulejos de Delfim Amorim $\quad 68$

$\begin{array}{ll}\text { azulejos de athos bulcão } & 73\end{array}$

$\begin{array}{ll}O \text { artista Athos Bulcão } & 73\end{array}$

Integração na arquitetura e anonimato da obra pública 84

Composição, processo criativo, temas e cores na azulejaria de Athos Bulcão 87

Execução e instalação dos painéis de azulejos de Athos Bulcão 94

$\begin{array}{ll}\text { Afinidades contemporâneas } & 97\end{array}$

$\begin{array}{ll}\text { considerações finais } & 101\end{array}$

$\begin{array}{ll}\text { referências } & 105\end{array}$

$\begin{array}{ll}\text { acervos pesquisados } & 115\end{array}$

$\begin{array}{ll}\text { apêndice 1: Entrevistas Sérgio Parada e Haroldo Pinheiro } & 117\end{array}$

apêndice 2: Lista de painéis do Athos Bulcão 133

apêndice 3: Levantamento iconográfico/fichas de catalogação 139

apêndice 4: Características de locais azulejados $\quad 155$

$\begin{array}{ll}\text { apêndice 5:Glossário } & 157\end{array}$ 


\section{resumo}

Estuda a presença do azulejo na arquitetura brasileira desde uma perspectiva histórica e de seu processo produtivo, conferindo particular atenção à obra azulejar do artista plástico Athos Bulcão. O azulejo como material de revestimento percorre a arquitetura brasileira desde suas origens. Forte traço da herança construtiva portuguesa no Brasil, de uso corrente nas edificações coloniais, o azulejo é recuperado no começo do século XX no movimento de formação de uma arquitetura brasileira de caráter nacional, primeiro no neocolonial, e depois pelos modernos. A obra de Athos Bulcão parte dessa retomada e avança em elaborações formais geométrico-abstratas, que atualiza o sentido do azulejo como um protagonista da obra arquitetônica.

\section{abstract}

This research studies the presence of wall tile in Brazilian architecture from a historical point of view and its productive process, granting special attention to Athos Bulcão wall tiles work. The use of wall tiles as a covering material goes back to the origins of Brazilian architecture. Strong feature of Portuguese architecture inheritance in Brazil, usual in colonial buildings, the use of wall tile recovered at the begin of $20^{\text {th }}$ century with the creation of an authentic Brazilian architecture with a strong national character, from the neo colonial style to the modern movement. Athos Bulcão's work begins with this restart and move forward to the development of geometric abstract forms, bringing wall tiles back as a protagonist in architecture. 


\section{introdução}

Esta pesquisa de mestrado articula-se em duas diferentes áreas do conhecimento: tecnologia e história o que, de certa forma, a diferencia tanto dos trabalhos acadêmicos pertencentes à área de história, como também daqueles da área tecnológica. O tema está na interface da história e da tecnologia. A pesquisa relaciona, ao mesmo tempo, questões históricas e culturais com questões tecnológicas, para estudar o uso do azulejo como revestimento integrado na arquitetura no Brasil.

Tanto o uso do azulejo na arquitetura brasileira, como os painéis de azulejo de Athos Bulcão foram pouco estudados. Devido à importância e relevância, no cenário brasileiro, o tema merece ser estudado com maiores cuidados e maior aprofundamento. Não é objetivo deste trabalho esgotar 0 assunto, pretende-se colaborar numa lacuna observada e contribuir com discussões para maior conhecimento do tema.

O azulejo é um material decorativo que se diferencia pela sua aplicação na arquitetura, pela configuração espacial que promove e pela adequação aos espaços para os quais é concebido (MANGUCCI, 1998). A parte da azulejaria que nos interessa estudar e destacar é aquela na qual o azulejo é pensado para um local específico, em áreas externas onde se ajusta às superfícies, valorizando, assim, o espaço arquitetônico.

O azulejo está ligado à arquitetura, é concebido para ser usado, visto e, portanto, analisado depois de aplicado nas paredes dos espaços a que se destina. Não é fácil isolá-lo das superfícies a que pertence, pois perderia todo o sentido e não poderia ser devidamente apreciado (CALADO, 1998). Ele pode ser analisado sob vários aspectos: o histórico, o técnico e o estético, contemplados neste trabalho para dar visão geral e ampla do objeto estudado.

No período colonial, foi bastante usado em fachadas de casas e sobrados e no início do século XX, o neocolonial começa e retomar o seu uso, ainda que timidamente, em frontões de fachadas ou como detalhes em muros e paredes externas. Notamos, portanto, que em alguns períodos da história brasileira, o azulejo foi relegado ao esquecimento, até a segunda vinda de Le Corbusier ao Brasil, em 1936. O Moderno não assimilava o uso do azulejo, mas o arquiteto francês 
${ }^{1}$ Ver mais sobre este assunto em: BOSCHI, Anselmo. Uma análise do setor de revestimentos cerâmicos.Cerâmica Industrial, 7 (2) mar.labr., p.8 a 13, 2002; SEIBEL, Silene, MEYERSTAMER, Joerg e MAGGI,Cláudio. Globalização e os desafios para as indústrias italiana, espanhola e brasileira de revestimentos cerâmicos. Cerâmica Industrial, 6 (6) nov.l dez., p.28 a 38, 2001. sugeriu que no Brasil, país tropical de clima quente e úmido, ele podia e deveria ser usado como material de proteção.

Posteriormente, foi usado como elemento ligado à arquitetura moderna; vários arquitetos contaram com a colaboração de artistas plásticos favoráveis à idéia da síntese das artes, porém, com diferentes interpretações. Depois dessa fase, os primeiros abandonaram o uso do azulejo como revestimento de áreas externas, sendo seu uso voltado quase que exclusivamente às áreas internas, como revestimento de cozinhas e banheiros, as também chamadas áreas molhadas.

Apesar deste uso restrito, com este estudo, queremos enfatizar que o azulejo é um produto também viável e com forte potencial para uso em fachadas e áreas externas, considerando-se que a indústria brasileira de revestimento cerâmico vem se desenvolvendo fortemente nesse segmento.

A bibliografia encontrada sobre azulejos portugueses é bem extensa, tanto contamos com obras de autores portugueses como Santos Simões, quanto com autores brasileiros como Dora Alcântara, Mário Barata, Sylvia Tigre de Hollanda Cavalcanti, entre outros.

Portugal mantém ainda atualmente extensa literatura abordando sua produção azulejar, é um país que adotou o azulejo como ícone de sua cultura e mantém essa tradição. Entre eles, citamos João Miguel dos Santos Simões que pode ser considerado um dos mais importantes pesquisadores da azulejaria portuguesa. Realizou vasta e séria pesquisa ao longo de vários anos. Com o apoio da Fundação Calouste Gulbenkian, de Lisboa, elaborou um plano de publicações sobre azulejaria portuguesa, resultando o "Corpus" do azulejo português.

Itália e Espanha são os países que detêm tecnologia de ponta na produção industrial de revestimentos cerâmicos, com algumas particularidades. A Itália é a principal responsável pelo desenvolvimento de novos produtos e equipamentos, investe na 'tradição' para agregar valor, enquanto que a Espanha tem o predomínio nos esmaltes, enfatiza o aspecto custo/benefício e trabalha com preços mais baixos. ${ }^{1}$

A bibliografia sobre azulejos no Brasil ainda é restrita e escassa e embora os dois volumes de Azulejaria Contemporânea no Brasil, de Frederico Morais apresentem ótimo panorama geral do assunto e tenham-nos fornecido subsídios para esta pesquisa, é obra que carece de rigor científico. A mesma carência foi constatada em relação à obra azulejar de Athos Bulcão, nota-se como exceção a publicação Athos Bulcão da Fundação Athos Bulcão de 2001, com densos textos 
de Agnaldo Farias e Severino Francisco, oferecendo uma visão completa e introspecção do trabalho geral do artista, não apenas dos seus azulejos.

O interesse inicial para a realização desta pesquisa surgiu em 2001, quando cursava disciplinas na Faculdade de Arquitetura e Urbanismo da Universidade de São Paulo e preparava o projeto de pesquisa para o mestrado. Nesse primeiro momento foi discutida com professores da FAU/USP a escolha do tema. Optamos pelo estudo do azulejo, como objeto de desenho industrial, considerando-se a minha experiência anterior de quatro anos de trabalho na IASA Indústria de Azulejos S. A., em Recife, onde realizava desenvolvimento de novos produtos.

Foi nessa época que surgiu a hipótese: por que no Brasil o azulejo deixou de ser 0 revestimento mais usado em fachadas? Qual o motivo do abandono, ou discriminação do uso do azulejo como revestimento de áreas externas?

Chamou-me a atenção também o trabalho de alguns arquitetos e artistas plásticos que utilizaram o azulejo em suas obras, entre eles Athos Bulcão, e a maneira peculiar com que integravam artes plásticas e arquitetura.

É curioso um certo anonimato e desconhecimento mais generalizado em torno da obra de Athos Bulcão, que de certa forma me fez acreditar que sua obra seria bom objeto de estudo, já que extremamente rica, fascinante, múltipla e não apenas na azulejaria. Desconhecimento que em parte decorre de uma atitude do próprio artista, induzindo a um anonimato de suas obras por não assiná-las, sua obra de arte pública se confunde com a paisagem da cidade.

A escassez de trabalhos acadêmicos sobre a obra de Athos Bulcão, juntamente com a inquietação e a vontade de questionar e discutir sobre o abandono do azulejo na arquitetura brasileira, justificam a escolha do tema desta pesquisa. A opção por estudar os painéis de Athos Bulcão não foi aleatória. Dentro da produção moderna e contemporânea brasileira de painéis de azulejos, o artista se destaca com obra diferenciada, possuidora de qualidade e quantidade suficientes.

Além de responder a hipótese formulada, um dos objetivos deste trabalho é que esta pesquisa contribua para a preservação da riqueza dos azulejos no Brasil e também desperte 0 interesse pelo trabalho criativo dos artistas do azulejo contemporâneo.

Uma das preocupações iniciais da pesquisa era investigar o escasso uso de azulejo como material de revestimento externo. Em seus desdobramentos o contato com a obra de Athos Bulcão acabou por levantar atenção e reorientar os propósitos originais. 
Primeiramente resgatamos a evolução da azulejaria no Brasil, com seus usos, seu desenvolvimento, seus processos de fabricação e suas ligações com os movimentos artísticos e arquitetônicos; depois, discute-se o uso do azulejo como elemento no "Movimento Moderno" no Brasil; traçamos o perfil biográfico do artista Athos Bulcão, contextualizando seu período de atuação e buscando compreendê-lo; e por fim, analisamos o processo criativo e a produção de painéis de azulejos de Athos Bulcão, ilustrando o uso de azulejos integrados de maneira artística à arquitetura, inclusive em áreas externas.

A primeira etapa da pesquisa concentrou-se na revisão bibliográfica do histórico do aparecimento do azulejo na arquitetura, na busca das raízes da azulejaria no Brasil, que inclui a origem do azulejo, seus diversos tipos e estilos desde o século XVII ao XX, enfatizando como 0 azulejo aparece na arquitetura moderna. Foram consultadas referências bibliográficas como teses, dissertações, artigos e livros com relação a trabalhos relevantes de azulejos e azulejaria em murais e fachadas na arquitetura brasileira, entre elas as obras de João Miguel dos Santos Simões, Dora Alcântara, Frederico Morais e Sylvia Tigre de Hollanda Cavalcanti. Em relação à análise da obra do artista plástico Athos Bulcão os textos mais significativos foram de Agnaldo Farias e de Severino Francisco.

No primeiro capítulo encontra-se a revisão bibliográfica sobre o azulejo e seu uso na arquitetura brasileira, mostrando como chegou ao país, como se deu seu desenvolvimento, como foram suas aplicações e sua evolução. Aqui se inclui também o azulejo como revestimento cerâmico para fachadas, um rápido contexto da indústria de revestimentos cerâmicos no Brasil abordando, inclusive os processos de produção mais usados e algumas técnicas de decoração.

O segundo capítulo inicia-se com um breve contexto das artes plásticas e da política nos anos 40/50, período de grandes mudanças e importância no cenário nacional. Discute-se o uso do azulejo como elemento de tradição na arquitetura brasileira, como apareceu na arquitetura moderna, como foi recuperado pelos modernos, como se integrou à arquitetura brasileira e à identidade nacional, destacando-se os painéis do prédio do Ministério da Educação e Saúde, no Rio de Janeiro, o caso da empresa Osiarte e os azulejos do arquiteto Delfim Amorim. Mostra-se também certa relação do azulejo com o painel e a síntese das artes.

Apesar da multiplicidade da obra do artista plástico Athos Bulcão, que se desdobra em desenhos, pinturas, fotomontagens, programações visuais, divisórias, relevos e painéis de azulejos; no terceiro capítulo, discute-se com maior destaque o seu trabalho de integração da arte na 
arquitetura, especialmente seus painéis de azulejos. Sua obra toma novo rumo, nova dimensão quando se estuda o processo criativo do artista, analisando suas composições, temas, cores e também execução e instalação dos seus painéis de azulejos.

Dentre os arquivos consultados, os que tiveram maior importância para esta pesquisa foram os da: Biblioteca da Faculdade de Arquitetura e Urbanismo da Universidade de São Paulo, Biblioteca Central da Escola de Engenharia de São Carlos e Acervo da Fundação Athos Bulcão.

Como a literatura encontrada foi insuficiente para atender os objetivos, foi necessário agregar outras metodologias de pesquisa tais como visitas a prédios com revestimentos em azulejos e procedimentos de entrevistas para entender a postura profissional de Delfim Amorim, Petrônio Cunha e Athos Bulcão. Estas seguiram roteiros específicos, considerando-se a relação do entrevistado com o objeto de estudo e visaram a informações adicionais e inéditas esclarecendo pontos relevantes.

A primeira entrevista foi realizada em julho de 2003, em Recife, com o Senhor Luiz Domingos dos Santos, artesão que trabalhou executando a pintura de azulejos para o arquiteto Delfim Amorim. No momento inicial, a pesquisa tinha também como objetivo estudar e analisar os projetos de fachadas com azulejos do arquiteto Delfim Amorim. Devido à dificuldade encontrada para obtenção de material referente ao arquiteto, não foi possível incluí-lo como gostaria neste trabalho.

A segunda entrevista foi realizada em fevereiro de 2004, em Olinda, com o artista plástico e arquiteto Petrônio Cunha, que usa o azulejo como módulo de composição em seus projetos para murais e revestimentos externos.

Em abril de 2005 foram realizadas entrevistas com Valeria Cabral, responsável pelo acervo de Athos Bulcão, Eduardo Cabral, criador e idealizador da Fundação Athos Bulcão; Haroldo Pinheiro, e Sergio Parada, arquitetos que trabalharam com Athos, estas últimas, transcritas no Apêndice 1.

No Apêndice 2 encontra-se a listagem dos painéis projetados por Athos Bulcão, contendo 0 ano de execução, o edifício, a cidade, o endereço, a localização no edifício, 0 arquiteto autor da obra onde o painel está inserido, o material, as medidas do material e as cores. A sua elaboração teve como modelo inicial, uma lista das obras do artista plástico, cedida por ocasião da pesquisa no acervo da Fundação Athos Bulcão. Nova listagem foi elaborada com dados complementares e atualizados. 
A partir de 2001 tanto em viagens acadêmicas para apresentação de trabalhos e participação em congressos, como em viagens turísticas, foram fotografados os exemplares encontrados de revestimentos externos em azulejos. Foram registrados alguns marcos como a Igreja da São Francisco de Assis na Pampulha, Capela Nossa Senhora de Fátima em Brasília, Museu Oscar Niemeyer e murais de Poty em Curitiba, prédio do MES no Rio de Janeiro, mas também azulejos e fachadas de projetos de autores não identificados, com a finalidade de ilustrar determinados textos, no decorrer da pesquisa.

As visitas a sítios e prédios onde se encontram azulejos como revestimentos externos foram consideradas como pesquisa de campo com levantamento fotográfico. Em julho de 2003 foi feita uma catalogação das obras de Delfim Amorim, no Recife, nas quais estão presentes, ainda hoje, azulejos revestindo fachadas. Em fevereiro de 2004 foi feito, em Recife, um levantamento fotográfico de quatro projetos de azulejaria do artista plástico Petrônio Cunha. Em Brasília, em abril de 2005, foram feitas visitas a algumas obras de integração arquitetônica de Athos Bulcão, além dos projetos de painéis de azulejos.

$\mathrm{Na}$ execução deste trabalho foram separadas e identificadas imagens de interesse para ilustrar textos da dissertação. As imagens escaneadas foram inseridas ao longo dos textos dos capítulos com as respectivas referências das fontes pesquisadas e as que foram feitas durante as visitas de campo para a formulação do banco de dados do levantamento iconográfico, incluindo a ficha de levantamento de cada projeto, estão organizadas por cidades, no Apêndice 3. A organização e ordenação dos projetos catalogados tiveram prioridade, pela finalidade e relação direta com o objeto de estudo.

A partir do levantamento iconográfico da pesquisa foi possível montar um quadro, que se encontra no Apêndice 4, contendo o resumo das características das construções onde o azulejo é usado como revestimento de paredes. 


\section{o azulejo}

\section{O azulejo e suas origens}

O azulejo é um elemento de forma conhecida ao qual se pode aplicar, com liberdade, e por intermédio do processo de impressão silk screen, desenhos de traços, planos, retículas, conservando relativa fidelidade nas texturas. Vem sendo utilizado e defendido por alguns, e esquecido e menosprezado por outros. Algumas de suas características e vantagens são: impermeabilidade adquirida pela aplicação do esmalte na superfície; resistência ao ataque dos ácidos, álcalis, umidade e vapores, nas condições normais de utilização; resistência a manchas (facilidade de limpeza); ausência de pintura; facilidade de aplicação; substituição a baixo custo; possibilidade de ser obtido em várias cores e diferentes desenhos, como, também, baixa expansão térmica (EGON, et al,1972).

A artista Maria Keil2 ${ }^{2}$ diz que muita gente tende a colocar o azulejo no plano do artesanato, concebendo-0, apenas, como material utilitário. Ela, no entanto, compreendeu que a função essencial do azulejo era envolver os espaços que revestia de qualidade e requinte, dar brilho e frescura, tornar agradáveis os lugares onde as pessoas viviam. Os azulejos ainda hoje continuam vistos como arte menor, mas, segundo a artista é bom "acautelarem-se com eles. Às vezes, para se divertirem com quem os trata como tal, combinam-se entre si malevolamente e fingem de casa de banho, ou de papel de embrulho, ou de qualquer outra coisa, etc., e ali ficam solidamente seguros nas paredes, a rir-se dos incautos" (SAPORITI, 1998, p.67).

Os significados da palavra azulejo são variados e, às vezes, confusos. Segundo a maioria das definições, a palavra azulejo, originária do árabe, significa uma placa pintada e vidrada em uma das faces, possuindo na outra, fendas ou um tipo de relevo para facilitar 0 assentamento.

O termo chegou a Portugal junto com os primeiros exemplares importados da Andaluzia e do Levante. Os escritos mais antigos onde foi encontrada a palavra azulejo ou azuleijo são do início do século XVI nos forais manuelinos. Os etimologistas que discordam quanto à origem da palavra azulejo concordam, porém, quanto à origem persa da palavra azul, vinda da Mesopotâmia e que define uma pedra semi-preciosa, de coloração intensa, o lápis-lazúli. Em resumo, o termo

2 Maria Keil, artista plástica portuguesa, já trabalhou com artes gráficas, cerâmicas, figurinos, ilustrações, fez poemas, tapeçarias e gravura. Optou pela azulejaria onde tem um trabalho reconhecido, renova o uso do azulejo e the restitui lugar de destaque na arquitetura e na arte portuguesa. 

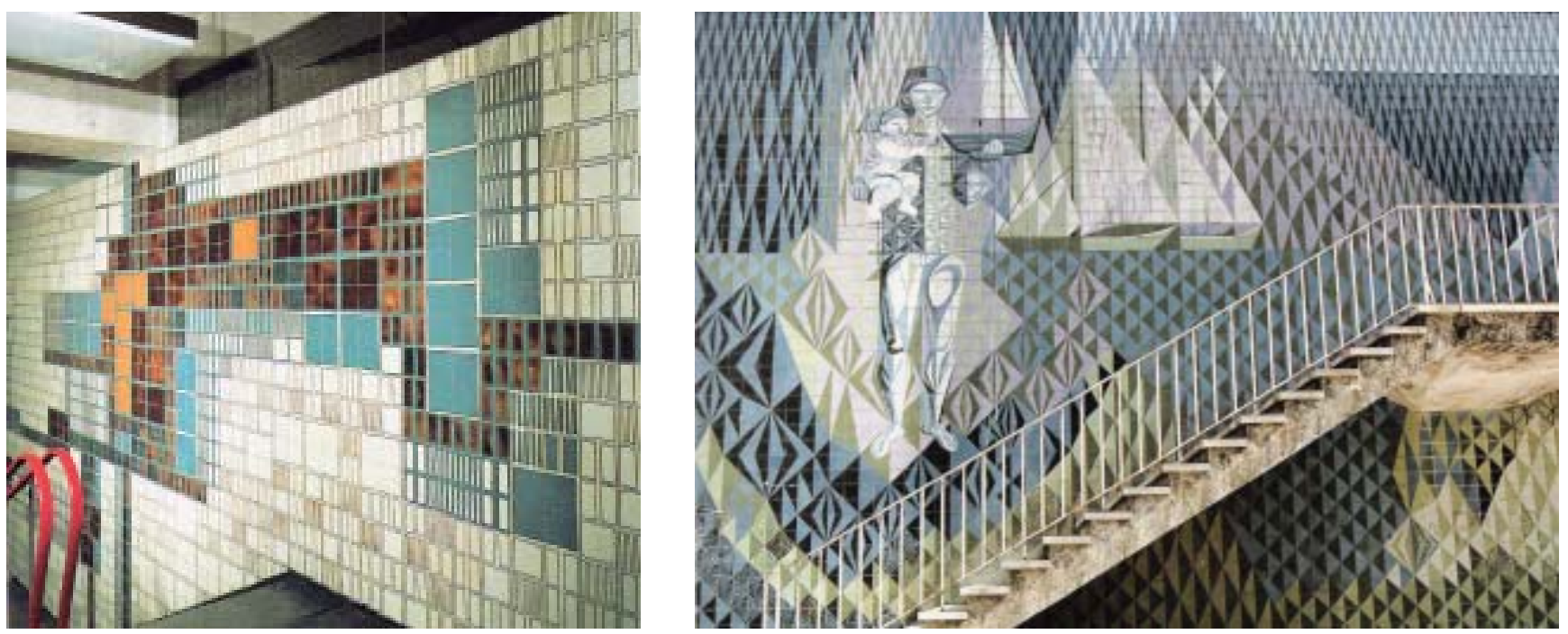

01. Painel de Maria Keil Estação Intendemte do Metrô de Lisboa, 1966. Fonte: SAPORITI, 98, p.79

02. Painel de Maria Keil Av. Infante Santo, Lisboa, 1956/58. Fonte: SAPORITI, 98, p.5.

azulejo contém a idéia de "pedra lisa e escorregadia" e também a idéia de coloração azul que lhe dá qualidades decorativas (SIMÕES, 1990).

Da palavra azulejo são derivados vários termos relativos à sua produção e aplicação, como, por exemplo, azulejar, decorar com azulejos; azulejado e azulejando, flexões verbais; azulejador, o artesão que faz azulejos; azulejeiro, o operário que coloca ou instala os azulejos, também conhecido como ladrilhador; azulejaria, vem sendo o termo usado para definir a arte do azulejo. "A azulejaria é o ramo da cerâmica cujos produtos se destinam à decoração, no sentido estrito do termo, e cuja aplicação é especificamente o revestimento de superfícies parietais, pavimentares, etc." (SIMÕES, 1990, p.35).

O azulejo é um produto cerâmico, isto é, um subproduto da cerâmica. O termo cerâmica, por sua vez, é usado para definir uma atividade e caracterizar os seus produtos. Implica o emprego de uma matéria prima: o barro e de uma técnica específica: a ação do fogo.

Cavalcanti (1963), presume que entre os mesopotâmicos a invenção e uso do azulejo não resultaram de causas artísticas, mas de necessidades construtivas de proteção contra umidade. Com o tempo, e entre outros povos, o azulejo se enriqueceu naturalmente de valores decorativos e sua utilidade prática ficou em segundo plano, superada por sua finalidade ornamental. Na Mesopotâmia, devido à escassez da pedra e pela abundância de solo úmido, os povos babilônicos tornaram-se ceramistas contumazes. Fabricavam tijolos com resistência e durabilidade e aperfeiçoaram a técnica da vitrificação. "Desenvolveram a técnica de fabricação de azulejos, com os quais revestiam suas paredes de tijolos. Assim as protegiam, fortaleciam e embelezavam". Os babilônios também revestiam de azulejos as torres dos seus templos (zigurates), com finalidade 
de proteção da ação de agentes químicos e físicos da atmosfera e dos ventos e das chuvas. Os Árabes, então, difundiram seus costumes pela Europa, principalmente na Espanha e Portugal. É interessante lembrar que esses primitivos azulejos eram em relevo, o que contradiz a explicação etimológica da palavra azulejo. Na Babilônia, as Portas de cidades eram monumentos importantes, com finalidades decorativas e defensivas, eram recobertas de azulejos, com representações de gênios protetores, dragões, touros alados, animais fantásticos e desenhos geométricos e florais.

Na Península Ibérica, a partir do século XII, Málaga tornou-se grande produtora e exportadora de azulejos. Depois, surgiram fábricas em outros lugares, como Granada e Sevilha, espalhando o uso desse revestimento ainda conservando suas características originais de relevo (CORONA e LEMOS, 1989).

Segundo Alcântara (2001), em Granada usavam a técnica do alicatado, que era o recorte de placas cerâmicas esmaltadas, com várias cores, em pequenas formas poligonais variadas, que eram agrupadas, formando desenhos. O alicatado era uma técnica de aplicação de cerâmica esmaltada, na qual as peças eram cortadas com alicates ou talhadas a golpes de pico, requerendo mão de obra altamente qualificada e especializada para sua aplicação.

Já em Sevilha, eram produzidos os azulejos em placas quadradas com colorido esmaltado, com efeito semelhante ao dos alicatados, porém, de mais fácil aplicação. Com a necessidade de reduzir os custos do alicatado, por volta de 1500, surgiu a técnica denominada "de corda". Sobre a peça biscoitada (cerâmica queimada) era feito o traço do desenho, que em seguida era reforçado com a cor escura de uma tinta graxa obtida com óleo de linhaça e manganês. Depois, preenchiase os espaços separados pela tinta graxa, com cores formadas a partir de óxidos dissolvidos em água (VALLADARES, 1982).

A técnica "de aresta ou concha" era um tipo de estampagem por pressão de um molde sobre a argila fresca. As saliências ou relevos, resultantes da pressão, eram divisórias que impediam a mistura das cores nas cavidades, acelerando o processo de fabricação.

Da Espanha a arte do azulejo foi para a ilha de Majorca, de onde vem o termo maiólica, técnica produtiva que usa o vidrado estanífero com técnicas pictóricas policromáticas pintadas sobre o azulejo. De Majorca o azulejo foi para a Itália de onde se espalhou para o restante da Europa. Apesar de a maiólica ter origem espanhola, a Itália foi o centro produtor mais importante. A técnica do branco estanífero surgiu, provavelmente, no Islã, durante a metade do século XII. Nesse processo aplicava-se o estanho sobre a superfície cerâmica, depois a peça era 
queimada para formar a camada vítrea metálica branca prateada. Os motivos decorativos eram então trabalhados em duas cores formadas a partir dos óxidos de cobre e magnésio, além da cor preta para fazer o contorno do desenho.

Segundo as fontes consultadas, a maioria das descrições feitas pelos estudiosos revela que o produto azulejo deve ter surgido na Pérsia, que foi o centro das técnicas de produção de azulejos empregados na Europa. Do oriente, o azulejo foi levado pelos árabes para a Itália e Espanha e de lá para Portugal, país onde mais se apreciou e mais se desenvolveu tal arte, estando presentes, principalmente, nas paredes como elementos decorativos, valorizando a arquitetura, tornando-se, assim, uma constante estética da arte decorativa portuguesa. Sendo o Brasil colonizado por portugueses, não é de se estranhar o nosso gosto pela azulejaria. No Brasil Colônia, foram muito apreciados e empregados azulejos portugueses na decoração arquitetônica, apesar das dificuldades de transporte e dos altos preços. Este teria sido o caminho mais provável percorrido pelo azulejo desde o seu aparecimento até sua chegada ao Brasil.

Segundo Alcântara (2001), o estudo sobre o azulejo e sua linguagem tem sua importância garantida pelo papel que este material representa em nossa cultura e deve ser feito como troca de experiência entre pesquisadores de diversas regiões do Brasil e também Portugal. Este intercâmbio é fundamental para melhor entendimento da linguagem do azulejo e de sua história.

Os azulejos foram usados de várias maneiras diferentes, criando estilos decorativos. Algumas vezes seguindo algum estilo arquitetônico, outras vezes agrupando estilos diferentes em um. Muitos estilos e tipos de azulejos serão explicados no decorrer dos textos.

O tipo de azulejaria de "tapetes" é um estilo decorativo que revela uma tradição mediterrânea bastante antiga. Foi assimilado pela civilização islâmica, introduzido na Península Ibérica, aplicado no Palácio de Alhambra, em Granada, chamado então, técnica do "alicatado", que era o recorte das placas cerâmicas esmaltadas, com diversas cores, em polígonos pequenos e variados, agrupados para formar desenhos como um mosaico cerâmico decorado (ALCÂNTARA, 2001).

Os azulejos, porém, não são exclusivos dos países tropicais, nem na utilização, nem na fabricação. A azulejaria desenvolveu-se plenamente nos países baixos. Bem famosos são os azulejos de Delft, na Holanda. Havendo também significativa produção no México, Península Ibérica, África do Norte e Oriente Próximo (BARATA, 1986). 

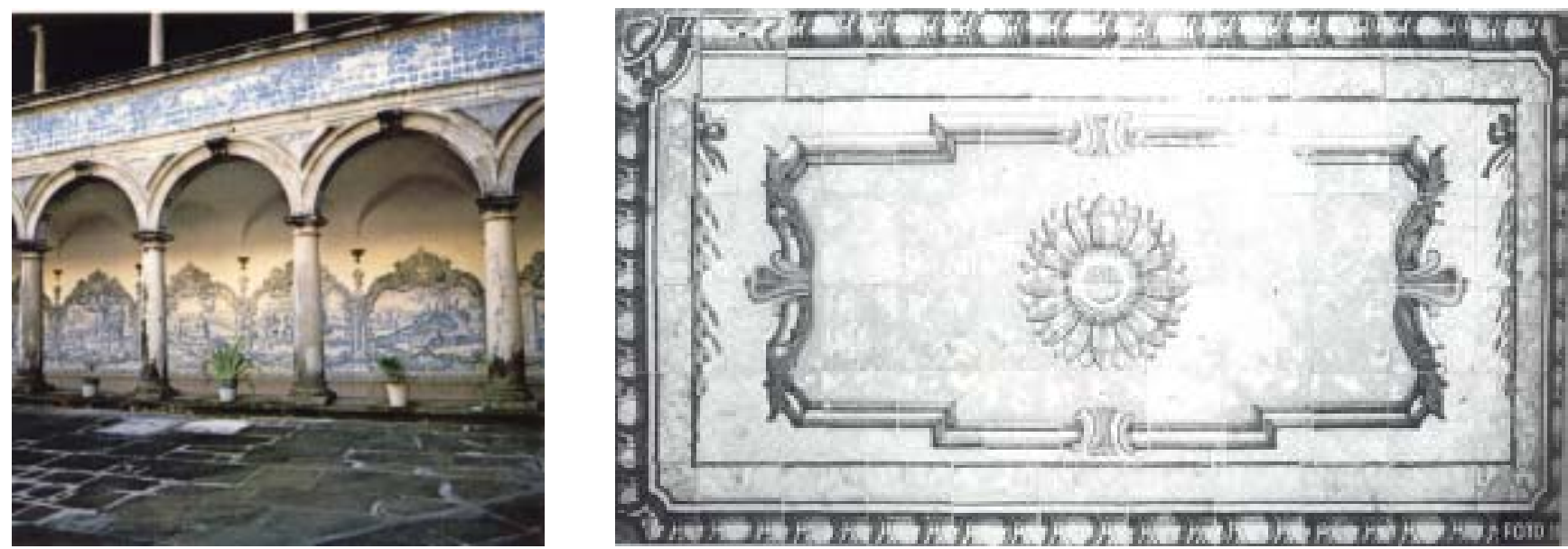

Alcântara (2001) revela que, as "alegorias" foram usadas por muito tempo, gênero decorativo romano bastante valorizado. Eram caracterizadas pelo aparecimento de formas híbridas: vegetais, animais, formas humanas e abstratas. Eram conhecidas como "grotescos", que como forma de decoração, estão presentes na história do azulejo português e da arte decorativa. A mesma autora destaca ainda o papel importante que a gravura teve na história. As obras de arte reproduzidas em gravuras permitiram difundir o conhecimento pelo mundo. Em Portugal, pintores de azulejos baseavam-se nessas gravuras para realizarem suas composições. Nas gravuras registravam-se informações sobre modas e hábitos da classe nobre e também dos povos em diversos países. Algumas gravuras registravam trajes típicos como as saias longas, os adornos de cabeça femininos, os penteados, trajes masculinos, as senhoras acompanhadas por pajens negros, como também músicos e seus instrumentos. Todas essas informações podem ser vistas através da azulejaria que serviu de suporte a essas gravuras. Assim, os azulejos tiveram papel importante na divulgação de um conhecimento geral para boa parte da população, uma vez que eram freqüentemente encontrados em lugares públicos muito freqüentados como igrejas e conventos. Alcântara ainda faz referência a um gênero de painel com marmoreados, medalhões e guirlandas. Por tradição cultural, em Portugal, foi mais comum o uso de azulejos pintados para dar a impressão de mármore, do que a utilização da própria pedra.

Apesar da moda do azulejo ter sido importada, foi em Portugal que desde as primeiras aplicações o azulejo foi utilizado com um sentido de monumentalidade e de integração arquitetônica, desconhecidos por outros povos. Os portugueses tiveram a ousadia de revestir paredes inventando composições e ritmos originais, enquanto que na Andaluzia, no Levante e no norte da África o

03. Claustro do Convento de São Francisco, Salvador, 1951 Fonte: BARDI, 1980, p.81.

04. Painel de azulejo "almofada marmoreada" (imitação de mármore) Portugal.

Fonte: ALCÂNTARA, 2001, p.60. 

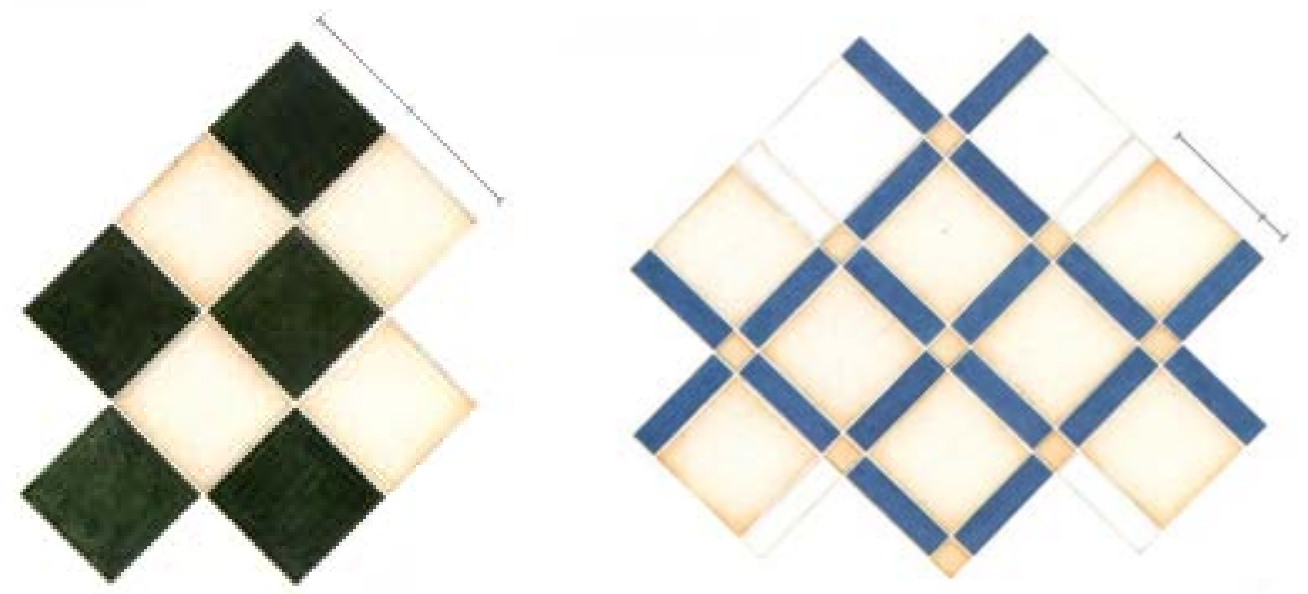

emprego do azulejo limitou-se à cobertura de silhares. Em Lisboa, as primeiras tentativas de fabricar ladrilhos vidrados datam do início do século XVI. Dessas experiências resultaram os primeiros azulejos lisos, esmaltados, pintados de verde-cobre, para serem usados em composição de enxadrezados na época manuelina. Também durante esse período, admite-se a instalação dos primeiros fornos do tipo Veneza, com capacidade de cozer o esmalte estanífero (CAVALCANTI, 2002).

É importante citar o terremoto ocorrido em Lisboa, em 1755, depois do qual, segundo Alcântara (1980) foi necessário organização e racionalização da produção de materiais de construção, inclusive de azulejos, para rapidamente reconstruir a cidade e abrigar os que perderam suas casas. 0 azulejo teve que se adaptar à nova exigência de industrialização. $O$ azulejo de tapete foi o tipo escolhido para ser fabricado por ser fácil e barata a sua produção, porém, com qualidade inferior. Com a Revolução Industrial, no século XIX, houve perda de atributos tradicionais e essenciais nos azulejos. A inadequação formal ao novo tipo de produção mecânica e 0 rebaixamento das qualidades artísticas dos azulejos industrializados foram as maiores perdas identificadas. Surgiu então, grande procura e a proliferação do azulejamento das fachadas, o que caracterizava não apenas o crescimento da indústria e do mercado consumidor, mas também a tentativa de os proprietários de casas e armazéns que ascendiam econômica e socialmente, exibirem seu novo status social, enobrecendo suas propriedades. 

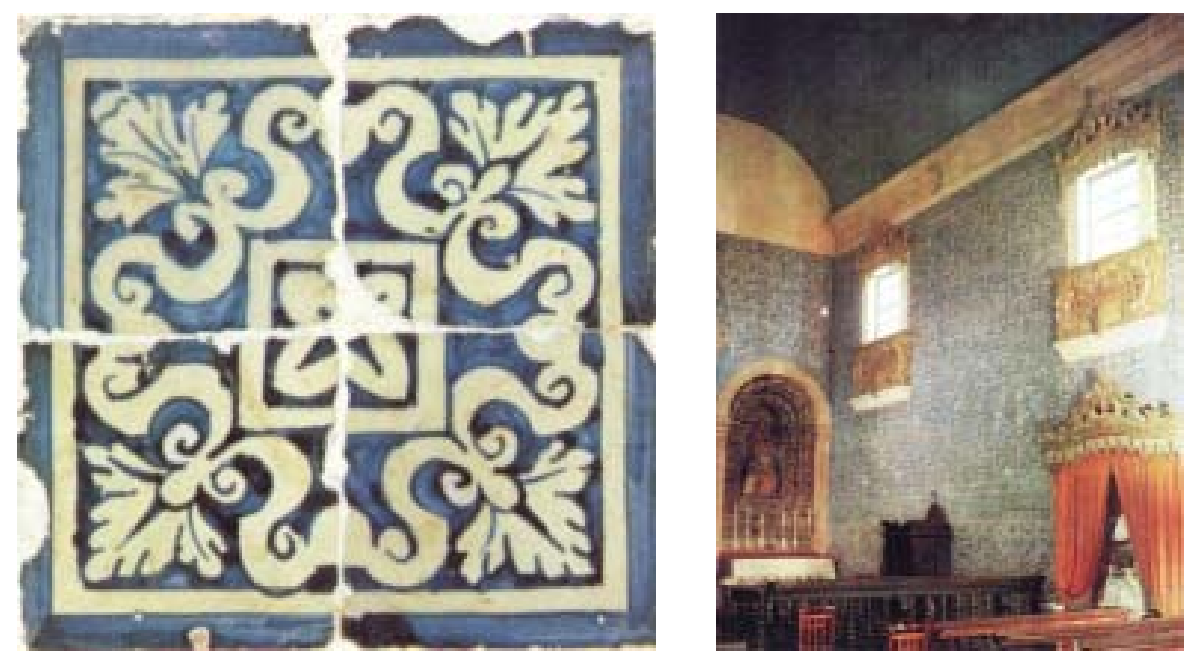

\section{Azulejaria portuguesa e sua introdução no Brasil}

De acordo com Simões (1980), as principais características que diferenciam a azulejaria portuguesa nos primeiros 25 anos do século XVII como monumentalidade, adequação à arquitetura e modernidade. $O$ azulejo chegou ao Brasil em sincronia com as demais artes e seguiu o mesmo processo de aculturação existente em Portugal. Ou seja, para o Brasil foi transportado o mesmo gosto, a mesma técnica e os mesmos materiais de Portugal.

Durante o século XVII, a azulejaria se desenvolveu nos dois países e atingiu altos níveis decorativos. No Brasil, os revestimentos com azulejos de padrões em policromia, formando tapetes enquadrados por cercaduras, não atingiram a monumentalidade de exemplos portugueses, mas foram bem representados em Pernambuco e Bahia.

Os gostos, modas, costumes, enfim, quase tudo o que a Corte produzia era trazido ao mesmo tempo para a Colônia. Aconteceu o mesmo com a azulejaria. No final do século XVII, a cerâmica policrômica no estilo italiano perdeu lugar para a novidade da porcelana azul, importada da China, e então copiada na Holanda, Inglaterra e na própria Itália. Os azulejos portugueses passaram a reproduzir em dois tons de azul os velhos padrões policrômicos. Para o Brasil eram mandados os melhores exemplares desse gênero, como por exemplo, os azulejos de padrão azul que forram o interior da igreja de Nossa Senhora dos Prazeres nos Montes Guararapes, em Pernambuco (SIMÕES, 1980).

Tecnicamente, essa mudança para monocromia azul representou uma simplificação dos processos produtivos. $\mathrm{O}$ emprego do cobalto, que produz as tonalidades azuis, era mais fácil que as outras cores, como também era melhor o seu comportamento nas operações de queima. No
06. Azulejo de cercadura. Fonte: BARDI, 1980, p.83

07. Igreja Nossa Senhora dos Prazeres, Monte dos Guararapes, Jaboatão.

Fonte: SIMÕES, 1965, estampa L.

08. Desenho de Wasth Rodriges retratando cercaduras de folhagens do Convento de Santa Teresa, Bahia. Fonte: RODRIGUES, fascículo VII estampa 138, 1975 

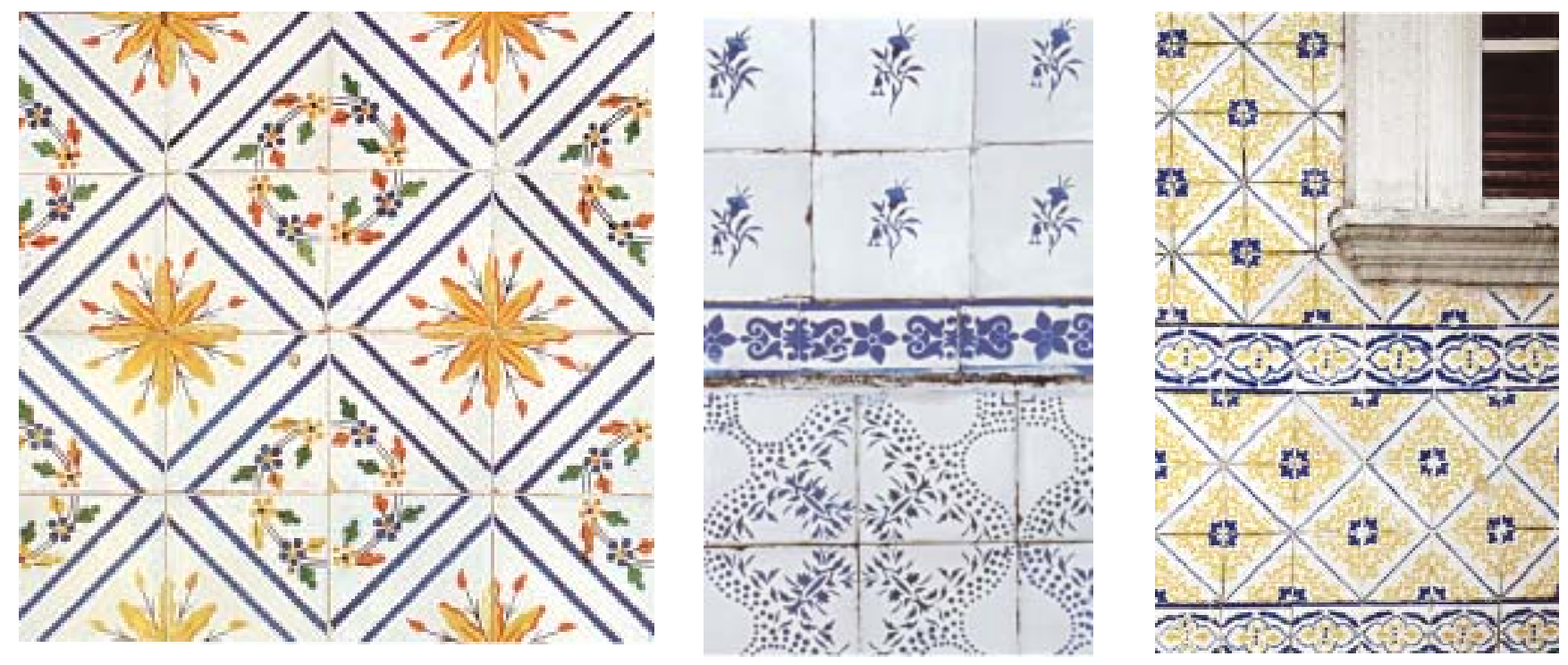

9. Azulejos portugueses de 13,5×13,5cm, no módulo 4x4, Recife, séc. XIX..

Fonte: CAVALCANTI, 2002, p.102.

10. Azulejos e frisos portugueses, inferior no módulo $4 \times 4$, e superior do tipo figura avulsa, Recife, séc. XIX.

Fonte: CAVALCANTI, 2002, p.33.

11. Azulejos padrão e cercadura franceses, Recife, séc. XIX. Fonte: CAVALCANTI, 2002, 26.

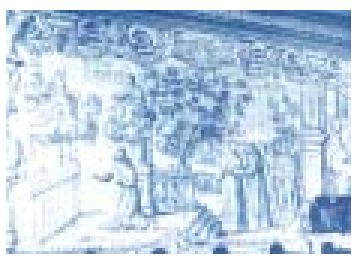

12. Painel na capela-mor do Convento de São Francisco, Salvador. Fonte: SIMÕES, 1965, estampa XXXI.

final do século XVII existiram, ao mesmo tempo, azulejos em policromia e monocromia, porém, estes últimos ganharam popularidade. Durante esse século, os azulejos mais utilizados nos interiores de templos e casas nobres foram as grandes composições de tapete, conseguidas com a repetição da padronagem em policromia (elemento). Eram usados tanto esquemas de quatro azulejos (2x2), quanto esquemas de dezesseis $(4 \times 4)$ a trinta e seis $(6 \times 6)$ azulejos. Os padrões eram definidos pelo módulo da repetição. Por exemplo, um padrão 2x2/1, significava repetição de quatro azulejos a um elemento.

Para revestir superfícies maiores, passou-se a fabricar e utilizar padrões de repetições

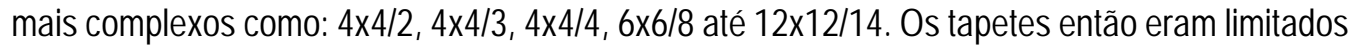
por frisos (frações retangulares de azulejos), cercaduras (azulejo total) ou barras (dois azulejos sobrepostos). Esses elementos acessórios dos tapetes tinham cantos próprios para dar continuidade ornamental aos ângulos de ligação (SIMÕES, 1980). Bardi (1980) explica que a aplicação em forma de tapete podia também ser composta de figuras, onde era preparado 0 cartão quadriculado e os artistas transferiam o desenho para os azulejos. Nos temas figurativos apareciam as vidas dos santos, cenas de misericórdia, temas civis, marítimos, mitológicos e episódios da vida doméstica.

Durante a ocupação dos holandeses em Pernambuco (1630 a 1654) vieram azulejos da Holanda para os palácios construídos na época do príncipe Nassau. Geralmente, as peças tinham uma figura central dentro de algum tipo de friso, ou apenas uma figura popular e os cantos contendo desenhos de aranhiços, labirintos chineses, cabeças de boi ou flores-de-lis. As peças não eram 

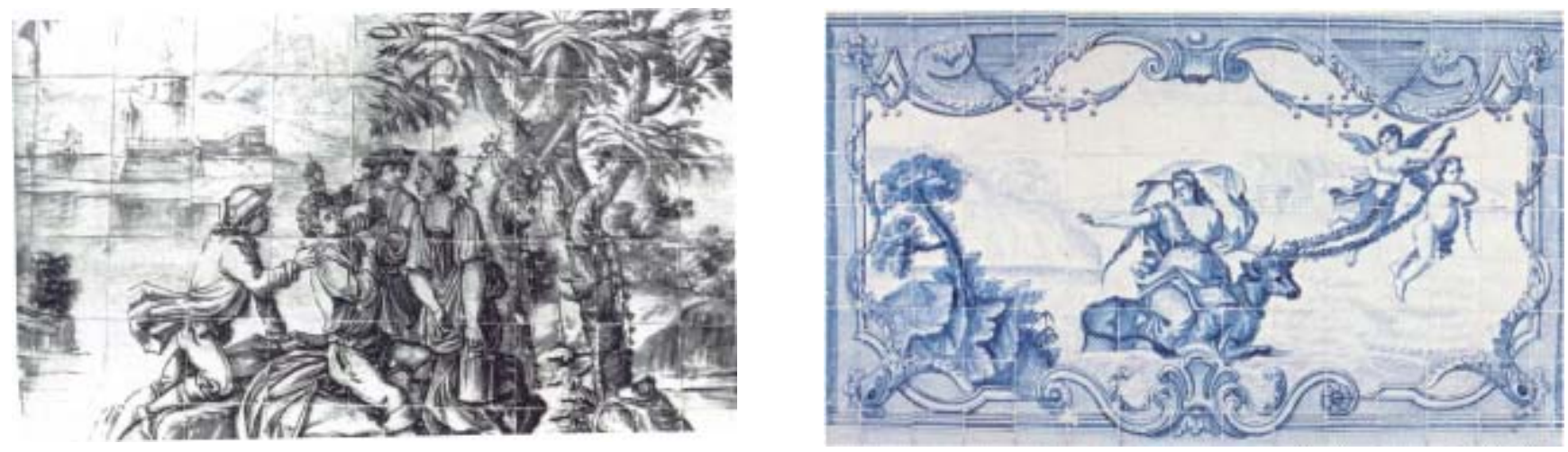

13. Painel no claustro do Convento de tão bem acabadas como as portuguesas e apresentavam dimensões menores (CAVALCANTI, 2002).

É interessante observar que já neste século (XVII), em Setúbal, Portugal, os revestimentos parietais começaram a mostrar preocupação com a escala. Quando o azulejo estava mais próximo da visão, o enxadrezado era menor. Na parte mais elevada do painel, era aumentada a escala do enxadrezado, compensando a distância. A composição sugeria tapetes e barras e existia uma preocupação em acompanhar as formas existentes, como por exemplo, de uma escada (ALCÂNTARA, 2001).

No século XVIII, o Marquês de Pombal, Primeiro Ministro de D. João VI, implantou um programa de industrialização manufatureira em Portugal. Criou-se a fábrica de Loiça do Rato, que simplificava os padrões de azulejos existentes. Os produtos eram feitos em série por processos artesanais, o que aumentou a produção, tornando o preço do azulejo mais acessível a um público maior (ALCÂNTARA, 1997).
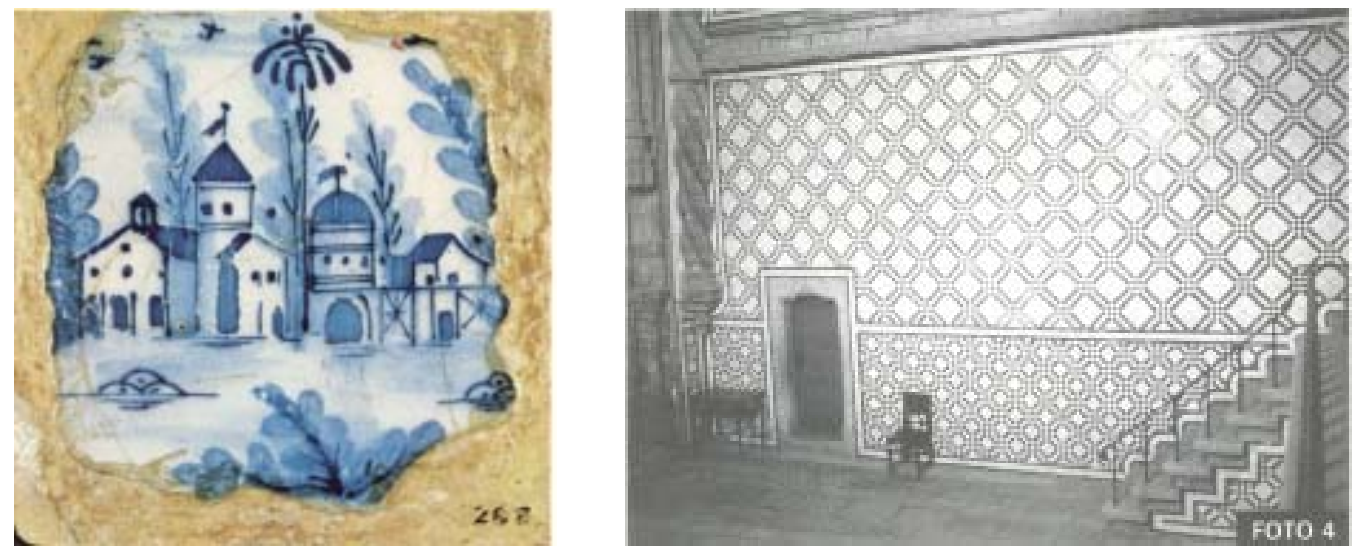

15. Azulejo holandês, fim do séc. XVIII.

Fonte: BARDI, 1980, p.87.

16. Nave da Igreja de Jesus de Setúbal. Revestimento de azulejo de caixilho.

Fonte: ALCÂNTARA, 2001, p.31. 

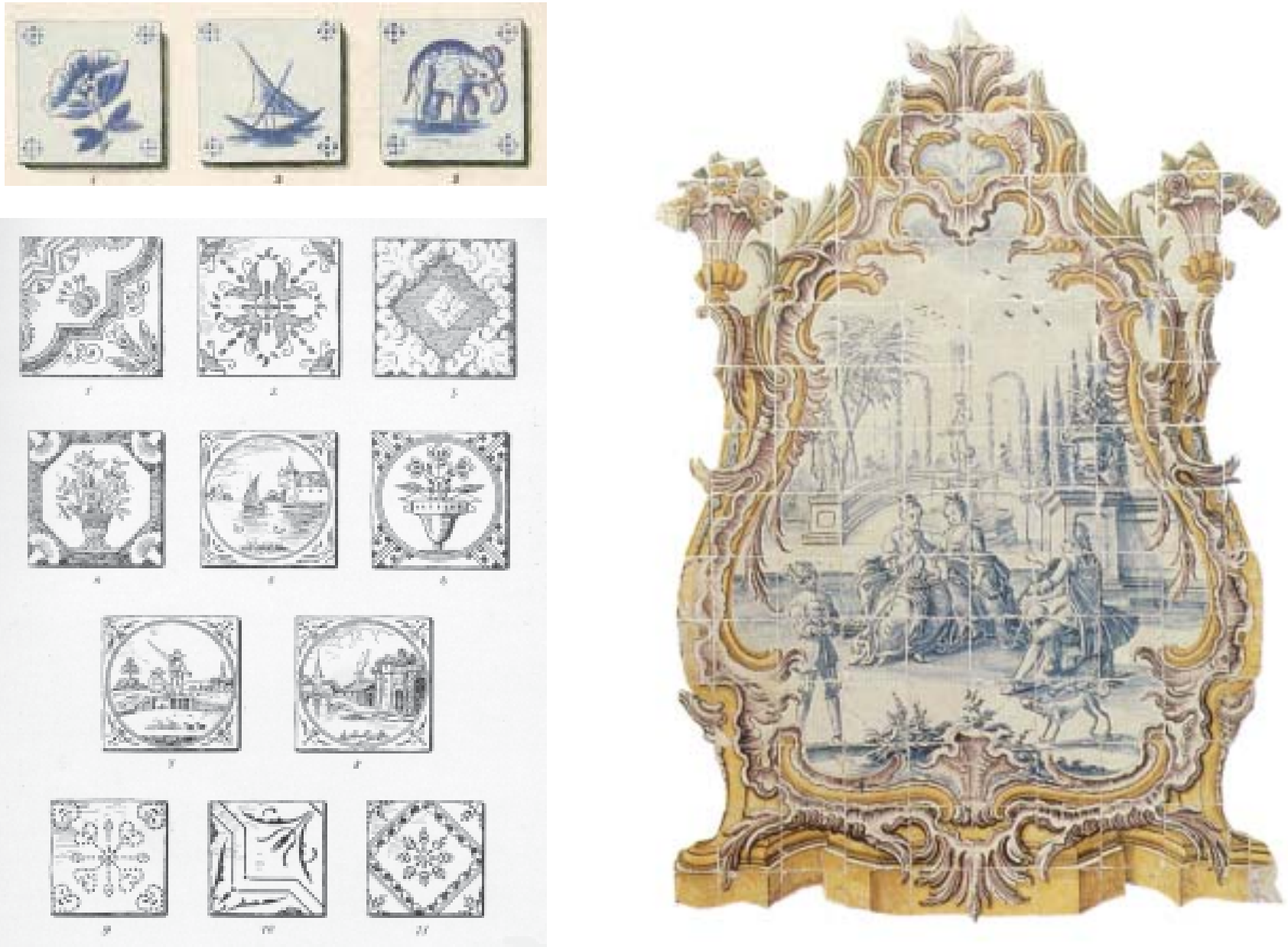

17. Desenho de Wasth Rodrigues retratando azulejos portugueses, séc. XVII, Rio de Janeiro. Fonte: RODRIGUES, 1975, fascículo VI, estampa 109.

18. Desenho de Wasth Rodrigues retratando azulejos portugueses, séc. XIX (1, 2 e 3); holandeses, séc. XIX e XVIII $(4,5,6,7$ e 8); francese, séc. XIX (9,10 e 11). Fonte: RODRIGUES, 1975, fascículo VI, estampa 110.

19. Painel com emulduramento rococó policromático, Museu do Açude. Fonte: ALCÂNTARA, 1997, p.72.
Segundo Simões (1965), o século XVIII caracteriza-se por ter sido um período também de técnicas artesanais, onde se destacaram alguns mestres portugueses de pintura de azulejos. Foram os chamados 'artistas pintores', que utilizaram o azulejo com intenção de fazer obra de arte e geralmente pintavam grandes composições figurativas e assinadas, fixando o gênero de pintura monumental, muito usada também no Brasil. O autor informa ainda que, o século XVIII, período de grande exportação de produtos portugueses para o Brasil, foi o século no qual o Brasil tornou-se 0 grande provedor de Portugal. Este proporcionou à Colônia um grande aumento no seu patrimônio artístico e a presença da azulejaria portuguesa no Brasil foi bem significativa, tanto na quantidade como na qualidade dos exemplares, onde a utilização do azul de cobalto incorporado nos fundos brancos continuou existindo.

"Pode-se dizer, com verdade, que o Reino devolveu ao Brasil em barro esmaltado parte do ouro e das pedras que de lá recebeu e, se o ouro desapareceu há muito dos cofres do 

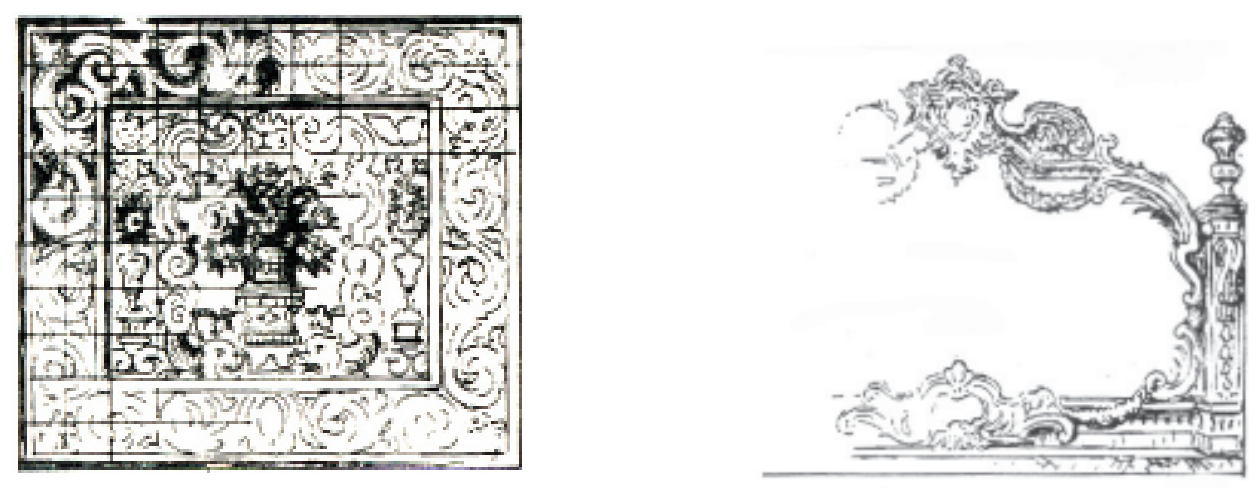

estado, ele está representado para sempre nos monumentos, nas talhas, nas imagens, nas alfaias, nos paramentos, nas pratarias e... nos azulejos, que de um e do outro lado do Atlântico, afirma a presença magnânima de D. João V e de sua esplendorosa época!" (SIMÕES, 1965, p.29).

Ainda segundo Simões (1965 e 1980) nesse período o azulejo estava definitivamente ligado à arquitetura, tornando-se indispensável para embelezar templos e solares e eram encomendados tanto no Reino como na Colônia com os mesmos cuidados e exigências. O azulejo, que estava tornando-se indispensável como elemento decorativo, encontrava no Brasil outras razões para sua grande aceitação. A escassez de materiais para acabamento externo das fachadas, juntamente com o clima quente e úmido do litoral brasileiro, que dificultava a conservação e impermeabilização, podem ter levado os construtores desse século a utilizar o azulejo, mais econômico (pela sua durabilidade), para enfeitar e também garantir a boa conservação das fachadas de igrejas e adros ${ }^{3}$. Surgia assim no Brasil o 'Azulejo de Fachada', desconhecido em Portugal.

Simões (1980) informa que, o século XVIII foi o período de fixação e 'nacionalização' do azulejo, ou seja, o uso do azulejo na arquitetura foi confirmado como uma tendência normal e tipicamente brasileira. O azulejo passou a ser usado com representações de temas figurativos e reduzido para a monocromia perdeu qualidade decorativa. Mas se impôs logo depois pela excelência material dos suportes e pelo maior cuidado na pintura. As ordens religiosas, principalmente os Frades Capuchinhos, foram os que retiveram a maior riqueza artística da época. Inúmeros são os Conventos, Hospitais e Missões brasileiras que eram ricamente adornados por azulejos portugueses.
20. Desenho de Wasth Rodrigues retratando painéis enquadrando vasos ou flores, entre golfinhos e volutas, com cercadura de folhagens. Fonte: RODRIGUES, 1975, p.306.

21. Desenho de Wasth Rodrigues retratando o estilo rococó em painéis mais movimentados, com ornamentos mais leves, muitas vezes na cor azul apenas na cena central, a cercadura em polocromia (amarelo, berde azeitona e cor de vinho) Fonte: RODRIGUES, 1975, p.306.
${ }^{3}$ Adro - terreno em frente e/ou em volta de igreja. 

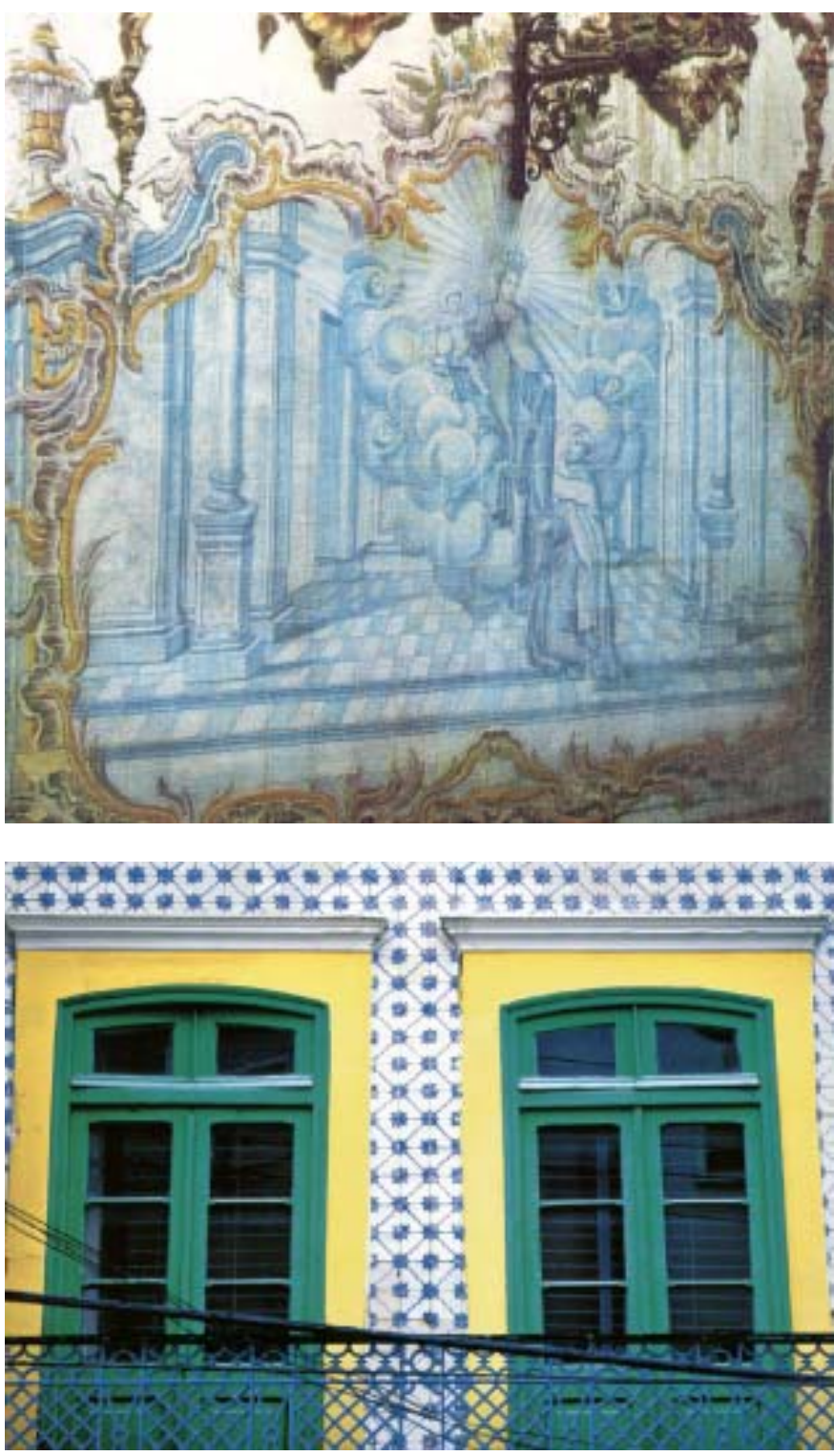

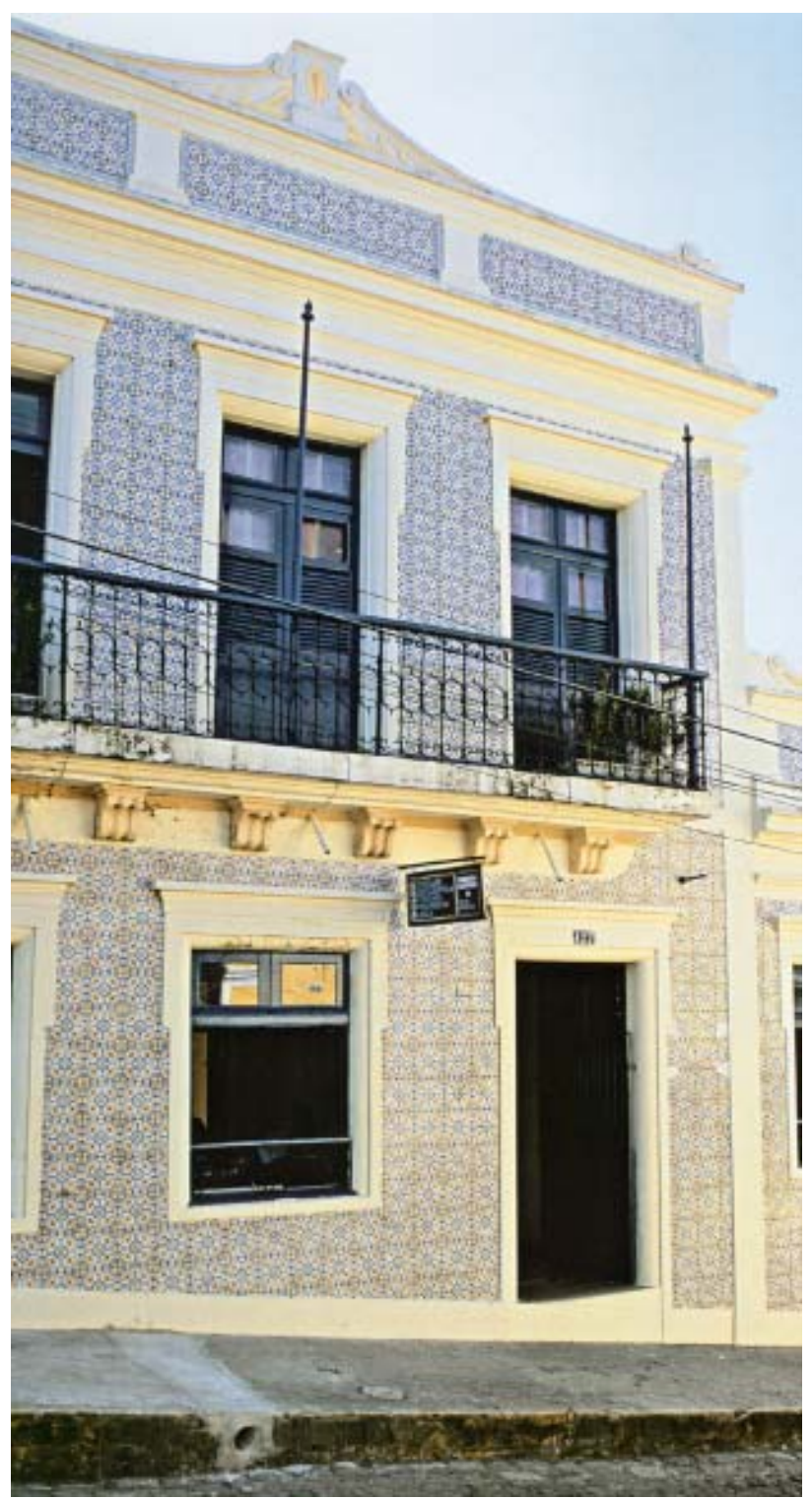

22. Painel capela-mor da Igreja de Santa Teresa, Olinda. Fonte: SIMÕES, 1965, estampa LVI.

23. Fachada de azulejos portugueses séc. XIX, Rua da Imperatriz, Recife. Fonte: CAVALCANTI, 2002

24. Fachada de azulejos franceses de $11 \times 11 \mathrm{~cm}$, séc. XIX, Recife. Fonte: CAVALCANTI, 2002, p.124.
Juntamente com a produção dos painéis figurativos pensados e executados para lugares específicos, produziram-se em Portugal os chamados 'azulejos ornamentais', produzidos em série, para decorações mais simples e podiam ser comprados por unidades, dúzias ou centenas. Independentes de lugares predeterminados permitiam várias combinações e com preços mais acessíveis, sendo utilizados em aposentos secundários como corredores, pequenas salas e cozinhas. Dentro deste tipo de azulejos ornamentais estão os chamados de 'figura avulsa', onde cada azulejo contém um motivo independente com desenhos simples e certa ingenuidade, pintados em azul, com temas de flores, aves, animais, figuras humanas ou barcos. Foram produzidos em 
Portugal, tornaram-se os azulejos 'populares', sempre graciosos, porém, não sendo encontrados muitos exemplares no Brasil. Outro tipo de azulejo seriado foi o dos painéis de vasos floridos, os chamados 'azulejos de vasos', encontrados com maior freqüência no Brasil, quase sempre emoldurados por figuras de sereias, golfinhos, anjinhos ou volutas barrocas (SIMÕES, 1965).

Durante o século XVIII, houve grande variedade de estilos de desenhos e pinturas em azulejos que refletiam as modas e gostos contemporâneos. Santos Simões em Azulejaria Portuguesa no Brasil dividiu o século XVIII em quatro períodos que se diferenciavam pictoricamente: época dos mestres (1700-1725); época das oficinas anônimas (1725-1755); época pombalina (1755-1780); época D. Maria I (1780-1808). A mesma divisão cronológica fez Cavalcanti (2002) para mostrar os diversos tipos de desenhos característicos de cada período.

Na segunda metade do século XVIII com o rococó, passa a predominar as dissimetrias e arritmias, com o retorno da polocromia em arranjos de molduras concheadas em tonalidades amarelas, verdes, roxas e azuis.

Durante o século XIX, vários acontecimentos e fatos históricos perturbaram as relações do Brasil com Portugal. Em 1808, chegou ao Brasil a corte de D. João VI e aconteceu a abertura dos portos do Brasil ao comércio internacional. Portugal encontrava-se abatido pelas guerras e desfalcado de recursos, deixou de ser o centro abastecedor e com a facilidade de comércio, 0 Brasil começou a importar azulejos de outros países como Holanda, Inglaterra, França, Bélgica, Alemanha e Espanha. Contudo, os produtos desses países apresentavam-se diferentes dos de Portugal. Segundo Cavalcanti (2002), os azulejos desses países apresentavam características de industrialização como pasta fina, dimensões pequenas e padronizadas, vidrado liso, espessura do biscoito reduzida e também decoração estampada ou decalcada.

Os construtores brasileiros recorreram ao azulejo para revestimento e proteção das fachadas das edificações. Na verdade, existe certa polêmica entre os estudiosos em relação a essa criação ou inovação do uso do azulejo em fachadas. Santos Simões, historiador português, afirma categoricamente que essa é uma invenção brasileira, enquanto que os especialistas brasileiros Dora Alcântara e Mário Barata atribuem tal invenção a Portugal.

Além de embelezar as fachadas, o azulejo tinha a função utilitária de proteção contra a umidade, típica do nosso clima tropical, agravada nas cidades litorâneas ou cidades situadas às margens de rios, devido à salinidade. O azulejo impermeabilizava e isolava os exteriores, garantindo melhor e mais longa conservação. As cidades que mais receberam fachadas azulejadas foram 

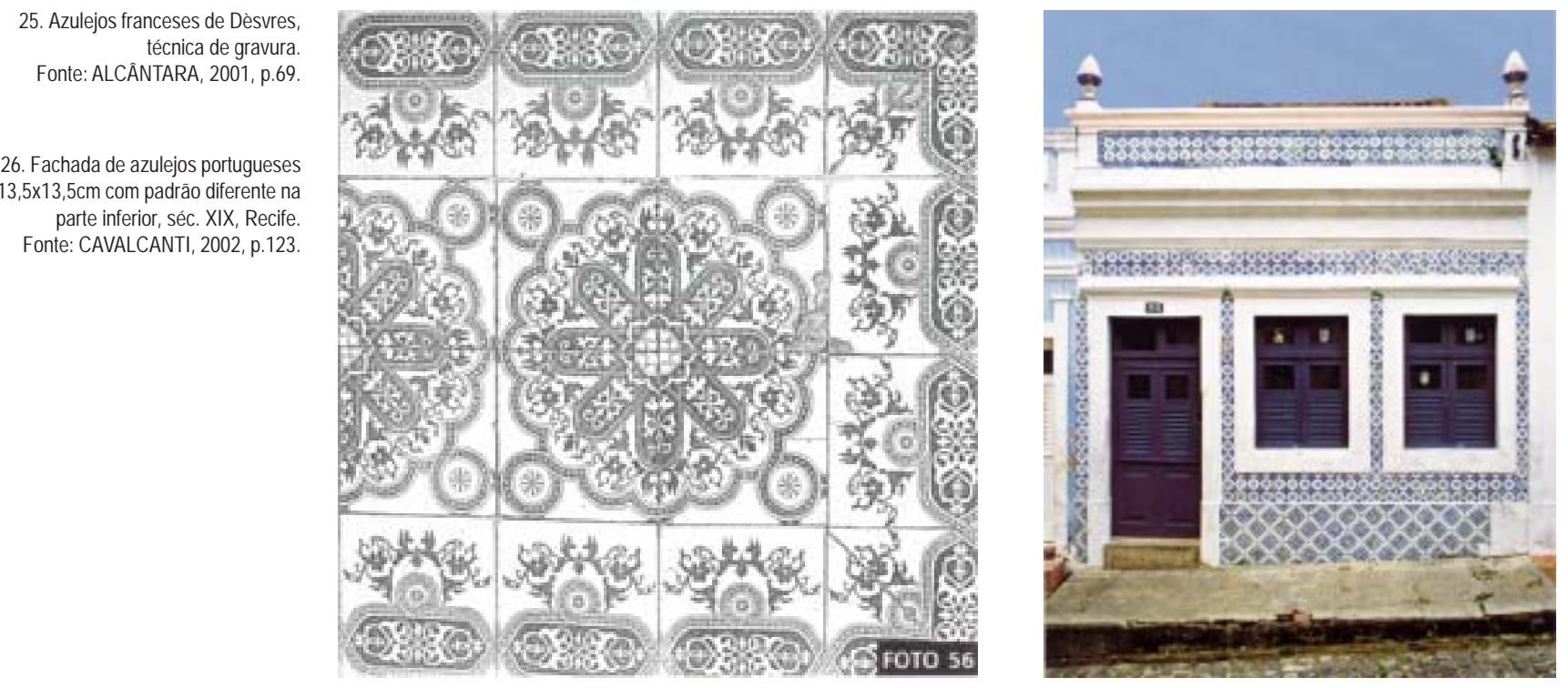

as que apresentavam tais características geográficas como Belém, São Luiz, Rio de Janeiro, Porto Alegre e Recife (CAVALCANTI, 2002). A autora revela uma informação que pode confirmar o início da aplicação do azulejo na arquitetura civil. A primeira notícia da chegada de um carregamento de azulejos foi publicada no Diário de Pernambuco em 1837. A notícia informa que 1.400 azulejos foram trazidos num navio espanhol, vindo do Rio de Janeiro. Não informa, porém, a origem da embarcação, provavelmente, de Portugal, de onde vieram todos os primeiros azulejos. Outras notícias publicadas nos anos seguintes 1838, 1839 e 1840, já especificam que navios vindos de Lisboa traziam caixas de azulejos de Portugal.

Em relação ao uso do azulejo no revestimento de fachada, Alcântara (2001) continua a questionar se é uma criação brasileira. Na sua opinião, essa prática estabeleceu-se simultaneamente no Brasil e em Portugal. Existe documentação e exemplos de revestimentos azulejares dos terminais dos campanários desde o século XVI nos dois países; em Portugal existem também, desde o mesmo século, bancos de jardins revestidos de azulejos e fachadas voltadas para os jardins igualmente revestidas com azulejos. A autora nota que, em Portugal, a partir da Revolução Liberal, e com ascensão da classe burguesa, o azulejo passa a ser escolhido por este grupo social que não possuía gosto estético refinado de acordo com os padrões da época. Os azulejos semi-industrializados atendiam às necessidades dessa classe emergente. Como os sobrados eram geminados, só havia uma fachada aparente, que era a frontal onde, naturalmente, os azulejos eram colocados. 
No Brasil, o fenômeno foi semelhante. O país passou a Império, surgindo a necessidade de enriquecer sua singela arquitetura. Os portugueses que moraram no Brasil e retornaram a Portugal construíram suas "casas brasileiras" levando o novo gosto ou moda - fachadas revestidas de azulejos-, observa Simões (1965), verificando e defendendo sua idéia de que assim, se proliferou em Portugal o uso de azulejos em fachadas.

Logo que se restabeleceu a ordem em Portugal e reataram-se as relações comerciais com o Brasil Imperial, os azulejos portugueses retomaram a posição perdida e em pouco tempo superaram os azulejos estrangeiros. Entre 1860 e 1918, as fábricas de azulejos de Portugal voltaram a abastecer o Brasil. O processo de fabricação utilizado na época era o de estampilha semi-industrial, o mais comum. Consistia na aplicação de um molde, geralmente de metal, com os desenhos recortados, e aplicados sobre a peça cerâmica e, finalmente, 0 artesão coloria com um pincel o espaço aberto. Para os padrões em policromia, fazia-se um molde para cada cor. Nessa elaboração muitas peças saíam com defeito, mas não deixavam de ser utilizadas.

Na técnica usada anteriormente à estampilha, o motivo era desenhado em um cartão e perfurado, esse cartão era colocado sobre o azulejo e passava-se um pó de carvão muito fino pelos orifícios marcando no azulejo o contorno do desenho. O azulejador, então, com o pincel delineava esses contornos, completando a figura. A estampilha permitia a reprodução de desenhos menores e com mais detalhes (ALCANTARA, 2001).

A produção de azulejos pintados e vidrados não teve êxito no Brasil durante 0 século XIX. A primeira fábrica brasileira foi instalada em Niterói, no Rio de Janeiro, por volta de 1861 e se chamou Survillo \& Cia. Durante o século XIX houve, no Brasil, grande uso não só de azulejos portugueses como também os de outras procedências como os franceses. Nesses dois países a produção de azulejos era feita com algumas particularidades ou diferenças.

Cavalcanti (2002) documentou as diferenças entre azulejos portugueses e franceses encontrados em Pernambuco no século XIX. Quanto à dimensão, os portugueses mediam 13X13 e $14 \times 14$ centímetros e os franceses mediam 10,5x10,5 e 11,5x11,5 centímetros. Na modalidade azul e branco, os portugueses tinham o desenho azul sobre fundo branco mais nítido que os franceses (que apresentavam um esfumaçado azul em torno do desenho). No azulejo português era comum 0 desdobramento do mesmo em módulos de $2 \times 2$ e 4x4, enquanto que 0 azulejo francês tinha o padrão na própria peça. A autora destaca também que o revestimento azulejar português era contornado por frisos (metade do azulejo) de um mesmo padrão ou padrão parecido, 
formando vãos e marcando a barra inferior. O azulejar do tipo francês não utilizava frisos, raramente tinham cercadura que eram azulejos nas mesmas dimensões dos azulejos principais, mas com um padrão diferente.

Ainda em relação aos padrões de azulejos franceses, Alcântara (2001) faz referência a uma fábrica de Dèsvres, no norte da França, especializada em louça, que depois passou a produzir azulejos também, era comum as fábricas terem essa dupla função. A matéria prima para essa fábrica era obtida no Rio do Prata e com o interesse das cidades do litoral sul-americano pelo azulejo, a fábrica começou a produzi-lo para ser usado como lastro de navio. Nas proximidades do término da viagem os azulejos iam sendo vendidos. A autora revela uma técnica de decoração francesa onde o desenho era gravado em chapa metálica, transferido para um papel por ação química, depois colocado sobre a base estanífera do azulejo e levado ao forno, onde o papel era queimado ou soltava, deixando o desenho impresso. Com essa técnica, os motivos podiam ser muito mais elaborados e as imagens apresentavam pigmentação característica, pontinhos típicos de algumas impressões.

Retomando as fachadas de azulejos, na opinião de Alcântara (2001) São Luiz, capital do Maranhão, possui o conjunto de fachadas azulejadas dos mais interessantes, embora Belém possua um conjunto maior, apesar de muitas perdas. Com o ciclo da borracha na Amazônia, tanto São Luiz como Belém foram capitais do Estado do Grão Pará. São Luiz enriqueceu numa primeira fase. No final do século XIX e no século XX, a economia maranhense entra em declínio, começando o ciclo da borracha na Amazônia. Belém passa por uma fase de enriquecimento, documentada, inclusive, pelo azulejo. Nessa fase, enriquece também Manaus, como mostram seus sobradões azulejados. Em relação à disposição dos azulejos, a autora observa, em várias cidades brasileiras, uma composição fantasiosa com vários padrões na mesma fachada. Porém, em São Luiz, o padrão é único em cada revestimento. Nesta cidade, é comum encontrar as partes inferiores das paredes pintadas em cores mais escuras, como uma forma de proteger a parede dos respingos da chuva, nas ruas sem calçamento, hábito que permaneceu mesmo quando desnecessário. Foram registrados, em São Luiz, exemplos da parte inferior das fachadas revestidas com azulejos de padrões diferentes, ou com o mesmo padrão, porém, com outra disposição. A autora informa, ainda, que várias outras cidades brasileiras receberam azulejamento em fachadas. No Rio de Janeiro restam poucos vestígios de fachadas azulejadas, talvez, devido às transformações muito rápidas. Salvador também teve um conjunto de fachadas azulejadas, mas 


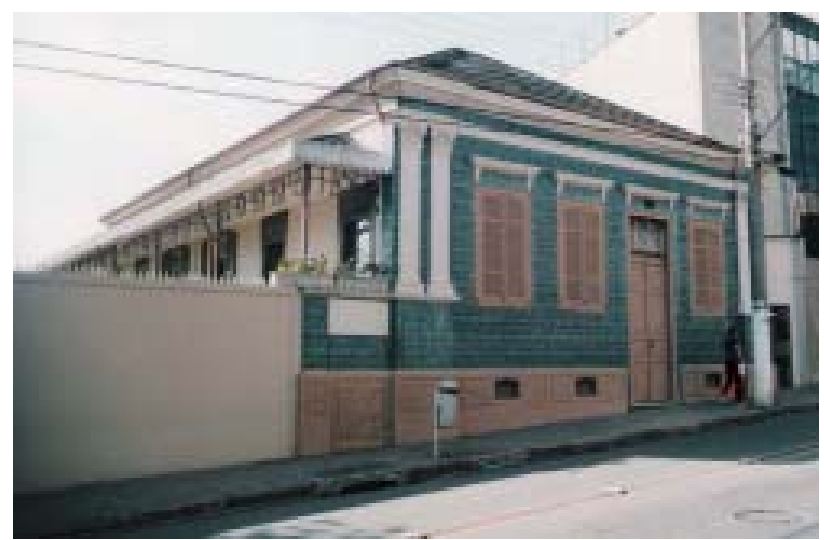

o que resta hoje é pouco expressivo. Recife, Olinda, Paranaguá, Porto Alegre e até cidades no interior como Sobral, no Ceará, e as cidades do Vale do Jaguaribe possuem fachadas azulejadas.

Foi constatada a presença do azulejo, às vezes de um mesmo padrão, em cidades distantes, dentro da grande extensão territorial brasileira. O uso de azulejo de fachadas é grande no Brasil, porém, em Portugal a concentração desse uso é bem maior. É lamentável que estejamos perdendo muito desse nosso patrimônio cultural. Os conjuntos de fachadas azulejadas, no Brasil, não têm sido preservados como merecem. Estão desaparecendo. Os azulejos, além de material decorativo são documentos desse longo processo de consolidação de nossa cultura.

O Primeiro Código Sanitário de 1894 faz referência a cozinhas e banheiros contendo barras impermeáveis de $1.50 \mathrm{~m}$ de altura, o texto sugere que as casas deveriam ser secas, ventiladas, iluminadas e fáceis de serem limpas (LEMOS, 1999).

Alcântara (1980), identificou problemas na escala arquitetônica nos azulejamentos externos de fachadas. Com a tendência ao crescimento vertical dos imóveis, o azulejo perdia a função decorativa, pois o motivo que deveria ser pequeno desaparecia quando muito afastado do observador, o que demonstrava falta de cuidado com a escala arquitetônica na aplicação do azulejo.

Com a facilidade para cópia de modelos e com a importação de matrizes estrangeiras, 0 azulejo perdeu a sua característica de exclusividade. Ao mesmo tempo, essa perda de atributos resulta no desaparecimento gradativo do azulejamento externo com finalidade decorativa. O uso do azulejo restringia-se, então, às áreas internas de serviço, como cozinhas e banheiros, com função exclusivamente utilitária. A perda dos atributos tradicionais da azulejaria portuguesa, tais como permanente modernidade, marcante individualidade e adequação à escala arquitetônica
27. Casa de azulejo, Limeira. Foto:Mateus Rosada.

28. Sede da Fazenda Morro Azul Iracemapólis. 


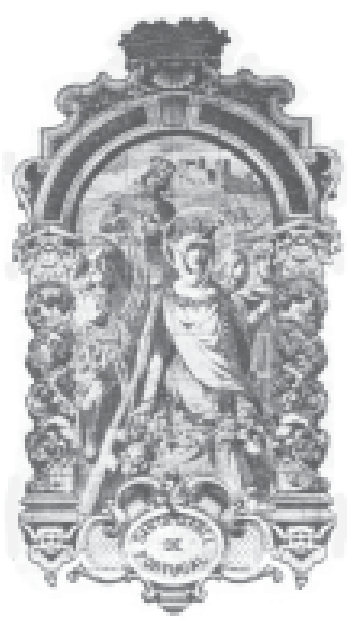

29. Painel de Jorge Colaço para a "Casa Lusa". Fonte: LEMOS, 1984, p.167.
4 "Casa de Azulejos" localizada na Rua Tiradentes $n^{0} 211$, na cidade de Limeira, interior de São Paulo, data do século XIX, já passou por reformas perdendo algumas características originais. Contudo, a fachada em azulejos de relevo composta por três padrões diferentes na cor verde ainda continua preservada. A data na fachada dá conta que a casa é de 1889. Provavelmente é mais antiga e a data refere-se à reforma em que foram feitos o telhado de ardósia, a platibanda, as colunas e a azulejaria. Segundo a proprietária Marlene D'Andrèa, os azulejos são franceses.

${ }^{5}$ Fazenda de café Morro Azul localizada na Rodovia Limeira, em Iracemápolis, interior de São Paulo teve sua sede construída entre 1868 e 1877. Todo material de construção veio da Europa a partir de Campinas em carros de boi. A fazenda Morro Azul é considerada a única sede rural brasileira com azulejos portugueses e ingleses na decoração da fachada. coincidia com o desaparecimento gradual do azulejamento de fachadas com finalidade decorativa, tanto em Portugal como no Brasil, conclui Alcântara (1980).

\section{Azulejaria no Brasil - aplicações e evolução}

A partir da República, as novas fachadas do ecletismo privilegiam a ornamentação em relevo dos estuques, abandonando o recobrimento com azulejos. Essa invenção brasileira continuou sendo aplicada apenas em Portugal, herdeiro desse gosto decorativo e prático. Tendemos a acreditar que isso não foi generalizado, pois chegamos a encontrar exemplos de ecletismo como é o caso da "casa de azulejos" de Limeira ${ }^{4}$ e a sede da Fazenda Morro Azul5. Porém, o surgimento do neocolonial,durante a primeira Grande Guerra conviveu com certas revivescências nacionalistas, inclusive a azulejaria (Lemos, 1984).

Além da azulejaria de fachada, que foi a mais relevante, o Brasil também recebeu de Portugal azulejos decorados e artísticos. Alguns estudiosos citam, particularmente, a atividade de Jorge Colaço como um grande artista que utilizou técnica mais pictórica, de grandes composições históricas, com a pretensão de retratar a tradição do azulejo português nos moldes saudosistas de uma visão patriótica, porém, não alcançou grande sucesso.

Um fato interessante que Cavalcanti (2002, p.29) relata é o surgimento de um Decreto Municipal banindo o uso de azulejar fachadas no Recife: "A lei n546 de 25 de fevereiro de 1909 proibia o emprego de ladrilho vidrado, vulgarmente chamado azulejo, nas fachadas dos prédios que se construírem ou reconstruírem neste município". Não se sabe qual o motivo para tal proibição. O que se pode notar é que tal proibição pode ter sido criada devido a um certo abandono do azulejo pelo ecletismo, que negava a herança cultural portuguesa. Foi uma proibição lamentável, porém, sem grandes danos, porque mesmo assim, o uso do azulejo em fachadas conseguiu sobreviver em edificações ecléticas até o seu retorno no Movimento Moderno brasileiro.

Nos anos 20 do século XX, houve o uso simultâneo de dois tipos de azulejos: os decorativos de tendência nostálgica de alguns portugueses arquitetos e donos de casas, que aplicavam painéis com motivos de sua terra natal e os empregados em instalações sanitárias, copas e cozinhas, como 'barras impermeáveis'. Estes eram importados da Inglaterra, Alemanha e França e decorados com desenhos padronizados discretos ou completamente lisos. Estas barras, geralmente eram arrematadas na parte superior por peças em relevo ilustradas no estilo Art Nouveau e Art Déco. Porém, foram os revestimentos antigos, dos tradicionais estabelecimentos 

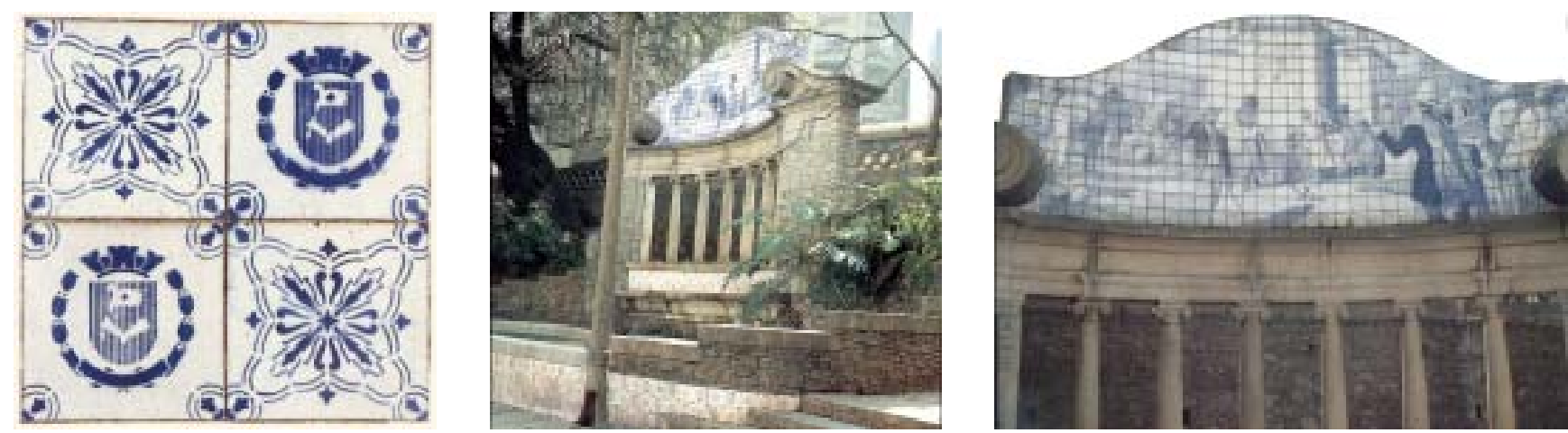

religiosos, com suas capelas e claustros ricamente adornados de azulejos pintados em argo da Memória, 1919/20, São Paulo. composições figurativas, retratando cenas bíblicas ou alegorias, que interessaram os neocolonialistas. Mais uma vez, foram os fabricantes portugueses que abasteceram o Brasil (LEMOS, 1984).

Ricardo Severo ${ }^{6}$ proclamava e defendia a idéia de uma 'arte nacional' com raiz cultural e étnica portuguesa. Em 1914, proferiu a conferencia 'A Arte Tradicional no Brasil', na qual recomendava com louvor "a valorização da arte tradicional como manifestação de nacionalidade e como elemento de constituição de uma arte brasileira. Discorrendo sobre as origens portuguesas da cultura brasileira, Severo defendia o estudo da arte colonial como orientação para 'perfeita cristalização da nacionalidade'. Severo não defendia uma postura propriamente conservadora" (SEGAWA, 2002, p.35).

Ricardo Severo era muito amigo do pintor Jorge Colaço $0^{7}$, a quem encomendou vários trabalhos. Das residências que projetou, destacam-se a sua própria na Rua Taguá e a residência Numa de Oliveira, na Avenida Paulista, ambas em São Paulo. Nos dois casos, o azulejo teve papel de destaque. A sua "Casa Lusa" era ricamente enfeitada com painéis azulejados internos e externos. Os painéis eram de autoria de Jorge Colaço, com paisagens referentes à Terra Mãe, cenas bucólicas e religiosas. Na residência Numa de Oliveira, o frontal era revestido com painéis de azulejos de bordos recortados, também com cenas bucólicas, procedentes do Porto, elaborados pelo mesmo artista e no beiral dos alpendres laterais tinham telhas de louça, vindas igualmente do Porto (TOLEDO, 1997).

Suas casas não eram cópias de casas antigas, apesar do caráter ou do emprego de elementos da arquitetura civil portuguesa dos séculos XVII e XVIII. Infelizmente, as residências projetadas por Ricardo Severo, exemplos de sua elegante arquitetura, foram todas destruídas.

6 Português formado em engenharia civil e de minas na Academia Politécnica do Porto, exilou-se no Brasil a partir de 1891, devido ao seu envolvimento com o movimento republicano português. Apesar da democracia ter sido implantada em Portugal (1910), Ricardo Severo radicalizou-se definitivamente no Brasil em 1909 e associou-se ao Escritório Ramos de Azevedo.

${ }^{7}$ Artista português que usava técnica pictórica onde pretendia reatar a tradição do azulejo português com uma visão saudosista e patriótica. 


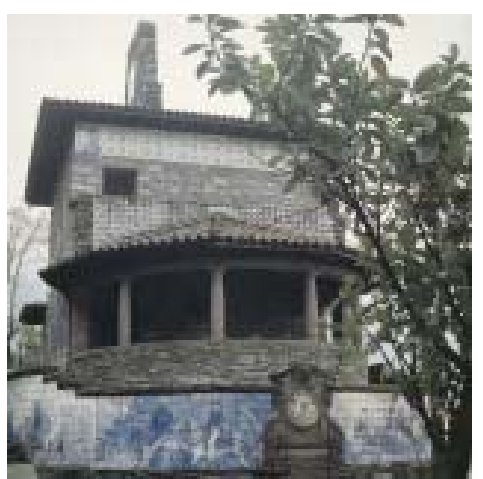

33. Rancho da Maioridade, Projeto de Victor Dubugras, 1922, Caminho do Mar, São Paulo. Fonte: MORAIS, 1988, p.20.

34. Detalhe do Painel de José Wasth Rodrigues, Rancho da Maioridade, Caminho do Mar, São Paulo, 1922 Fonte: MORAIS, 1988, p.21.

35. Azulejos de José Wasth Rodrigues,

Rancho da Maioridade, Caminho do Mar, São Paulo, 1922.

Fonte: MORAIS, 1988, p.21
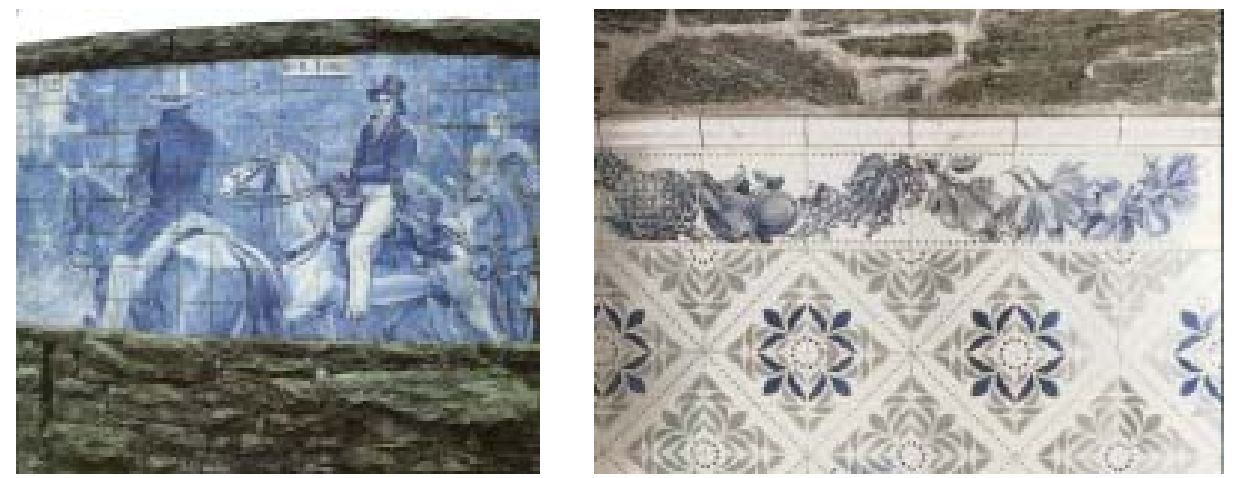

"As casas de Ricardo Severo, pelo contrário eram extremamente variadas e tratadas com toda a liberdade permitida pela técnica contemporânea. Não vacilava em jogar com os planos na distribuição das massas e, mais ainda, recuos progressivos em elevação, particularmente visíveis na casa do Guarujá. Na época colonial, jamais houve semelhantes exercícios de cintuosismo gratuito, e tampouco era possível cogitar seu grau de refinamento alcançado por Ricardo Severo. Portanto, suas obras eram modernas, mas concebidas de modo a evocar intensamente uma arquitetura do passado" (BRUAND, 2002, p.53).

Victor Dubugras ${ }^{8}$ possuía um espírito eclético e inovador, que o fazia pesquisar todas as fontes, para extrair delas o que achava melhor. Encarou o estilo neocolonial como uma oportunidade de sucesso, sem romper totalmente com as fases anteriores de sua obra (BRUAND, 2002).

A reurbanização do Largo da Memória em 1919, no centro da capital paulistana, executada quando Washington Luiz era prefeito de São Paulo e o conjunto de pousos no Caminho do Mar, monumentos comemorativos do centenário da Independência e construídos em 1922 ao longo da antiga estrada para Santos por encomenda do mesmo Washington Luiz, são obras que

${ }^{8}$ Arquiteto francês que estudou em Buenos Aires, foi outro que fez grande uso do azulejo em suas obras e parece ter sido convencido pela campanha de Ricardo Severo em favor do neocolonial.

${ }^{9}$ José Wasth Rodrigues realizou várias viagens pelo Brasil, a partir de 1918, documentou em desenhos a bico de pena nossa arquitetura da época colonial. Foi desenhista, pintor, historiador, perito em mobiliário e heráldica, além de conselheiro do Serviço do Patrimônio Histórico e Artístico Nacional.

hábil do granito, do azulejo, da pedra bruta e retomou alguns elementos clássicos da arquitetura luso-brasileira (TOLEDO, 1997).

No Largo da Memória, José Wasth Rodrigues ${ }^{9}$ pintou os azulejos para o painel e também dois tipos de azulejos aplicados nas fontes, um dos dois tipos leva um brasão da cidade de São Paulo, utilizado pela primeira vez em obra pública, criado pelo mesmo artista, juntamente com Guilherme de Almeida. 

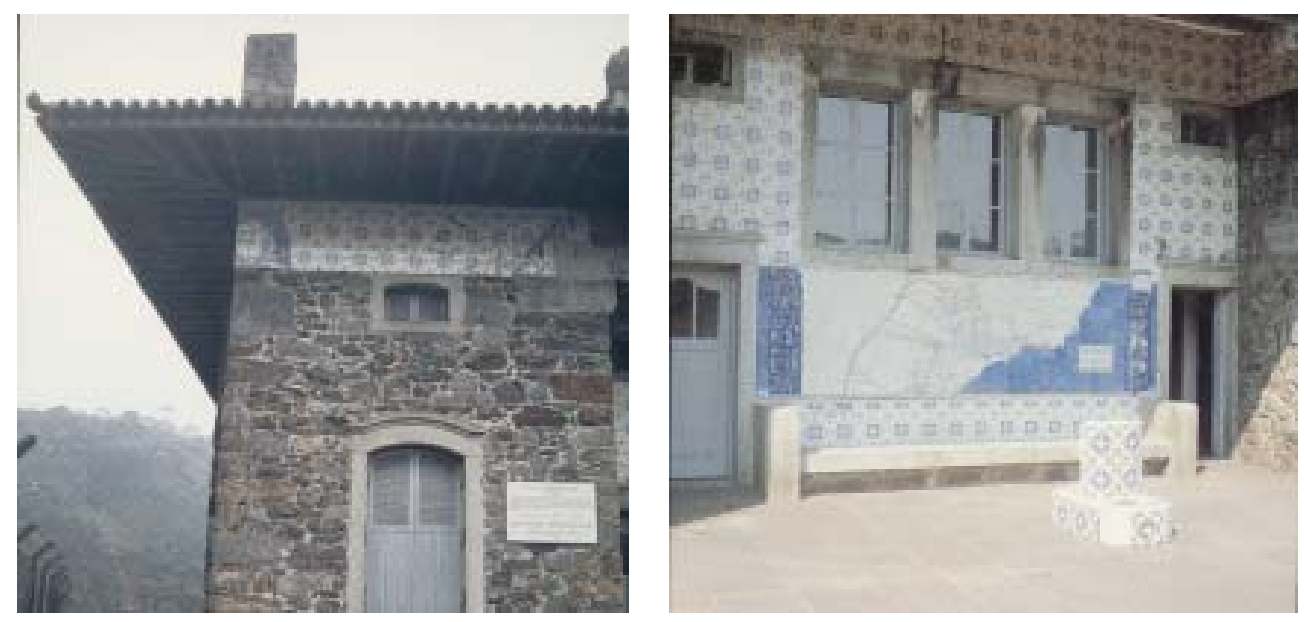

Os principais monumentos ao longo do Caminho do Mar são quatro: o Cruzeiro Quinhentista, localizado na baixada do Cubatão, retrata a presença dos jesuítas no local e o caminho do Padre José de Anchieta que subia a serra do Mar; o Rancho da Maioridade, que marca o antigo caminho da serra por onde D. Pedro I teria passado; o Pouso Paranapiacaba, no alto da serra, que é dedicado às façanhas dos primeiros automobilistas e o Padrão do Lorena (LEMOS, 1984).

Nos monumentos do Caminho do Mar, o clima apresenta bruscas alternâncias, ao qual o azulejo é material adequado. Esses monumentos foram construídos em locais estratégicos, para desfrutar a paisagem e marcar pontos onde cruzava a antiga Calçada do Lorena. Os painéis instalados retratam cenas da história do Caminho do Mar e da Calçada do Lorena, no interior do Pouso Paranapiacaba e do Rancho da Maioridade os painéis azulejados são de motivos diversos. Todos os azulejos foram desenhados por Wasth Rodrigues.

Os azulejos para o Largo da Memória foram produzidos pela fábrica Santa Catarina. É relevante lembrar que as peças vieram da Inglaterra e foram pintadas e queimadas na fábrica brasileira (TOLEDO, 1997). A Santa Catarina, que tinha razão social Fagundes Ranzini \& Cia, foi a primeira fábrica a produzir louças sanitárias industrialmente, era de propriedade de Romeu Ranzini e outros sócios pertencentes à elite paulistana. Romeu foi à Itália para contratar operários e à Alemanha, onde comprou o projeto da fábrica e algumas máquinas. A fábrica, em 1912, estava instalada na Lapa com fornos construídos em forma cilíndrica de chama invertida e diâmetros que variavam de quatro a oito metros. Utilizava como combustível carvão mineral importado de Cardiff e lenha nacional. A matéria-prima utilizada era proveniente do Estado de

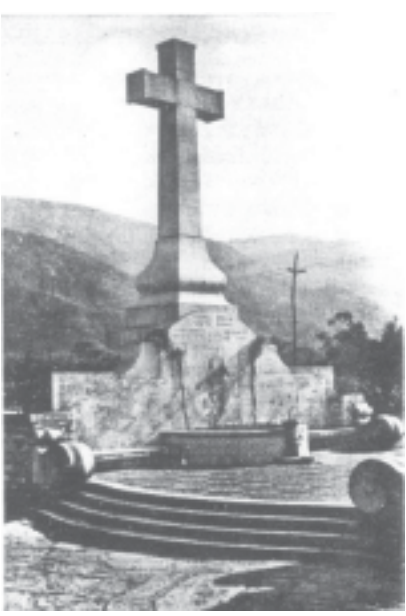

36. Azulejos de Wasth Rodrigues, Pouso Paranapiacaba,

Projeto de Victor Dubugras, 1922. Caminho do Mar,

São Paulo.

Fonte: MORAIS, 1988, p.22

37. Azulejos de Wasth Rodrigues, Pouso Paranapiacaba,

Projeto de Victor Dubugras, 1922, Caminho do Mar,

São Paulo.

Fonte: MORAIS, 1988, p.22

38. Cruzeiro Quinhentista 1922, Caminho do Mar. Fonte: LEMOS, 1984, p.170 


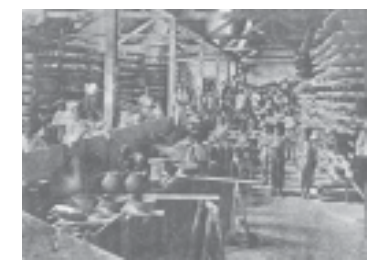

39. Interior da fábrica Santa Catarina, década de 20 Fonte: LEMOS, 1984, p.169.

40. e 41. Painéis de Paulo Ross São Paulo, 1931, São Paulo Fonte: MORAIS, 1988, p.33.
São Paulo: o caulim, vindo de Santo Amaro; a argila de São Caetano; o quartzo do Alto da Serra e o feldspato, de Perus (LEMOS, 1984).

Esta fábrica possuiu pequena produção de azulejos, alguns anos depois de inaugurada. Os painéis para Victor Dubugras, pintados por Wasth Rodrigues, foram queimados nesta empresa. Como não havia prática na fabricação de painéis, a queima foi feita de maneira improvisada. A técnica de pintura era "sobre esmalte", o desenho era pintado sobre a superfície branca vidrada e os pigmentos incorporados à base através da fusão. Os esmaltes, as fritas, os pigmentos e até o veículo para as cores "glass" eram importados. Os azulejos pintados eram colocados sobre grelhas refratárias como se fosse um forno contínuo tipo "túnel", onde as grelhas eram encostadas umas às outras e uma empurrando a seguinte, acionadas por um bastão de madeira. Nessas precárias condições, as temperaturas corretas para o esmalte não foram atingidas (LEMOS, 1984).

A partir dos anos 20, existiu no Brasil grande variedade de azulejos importados, principalmente alemães e ingleses, pois a produção nacional não atendia à demanda do novo surto de construções. Contudo, os azulejos do Caminho do Mar, pintados por Wasth Rodrigues, foram queimados, ainda, na fábrica da Lapa de Romeu Ranzini. Utilizaram uma técnica nova, um pouco mais aperfeiçoada para o cozimento, mas, ainda não conseguiram o controle correto de temperaturas adequadas aos diversos esmaltes. Algumas cores não atingiram boa fixação à base esmaltada.

Segundo Lemos (1984), o trabalho do Ateliê de Cerâmica Artística de Conrado Sorgenicht surgiu em torno de 1925, em São Paulo. Esse industrial possuía uma filial no Rio de Janeiro, que desde 1918 produzia painéis publicitários de azulejos decorados para anunciantes locais, os quais garantiam boa conservação dos textos ao ar livre. Porém, o primeiro trabalho importante de Conrado foi a série de painéis sobre a vida de Santa Teresa de Ávila, para o claustro do Carmelo,

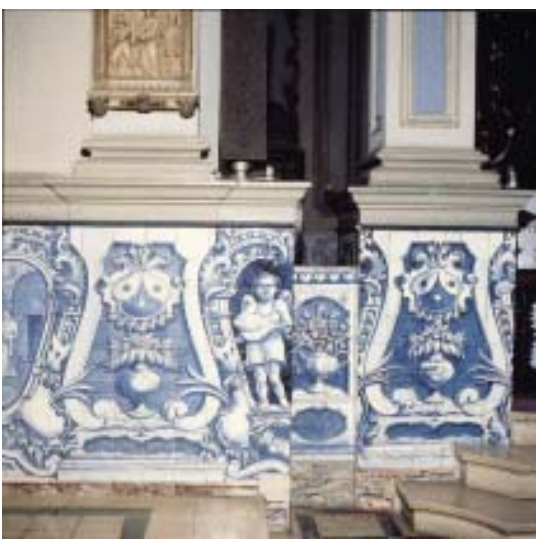



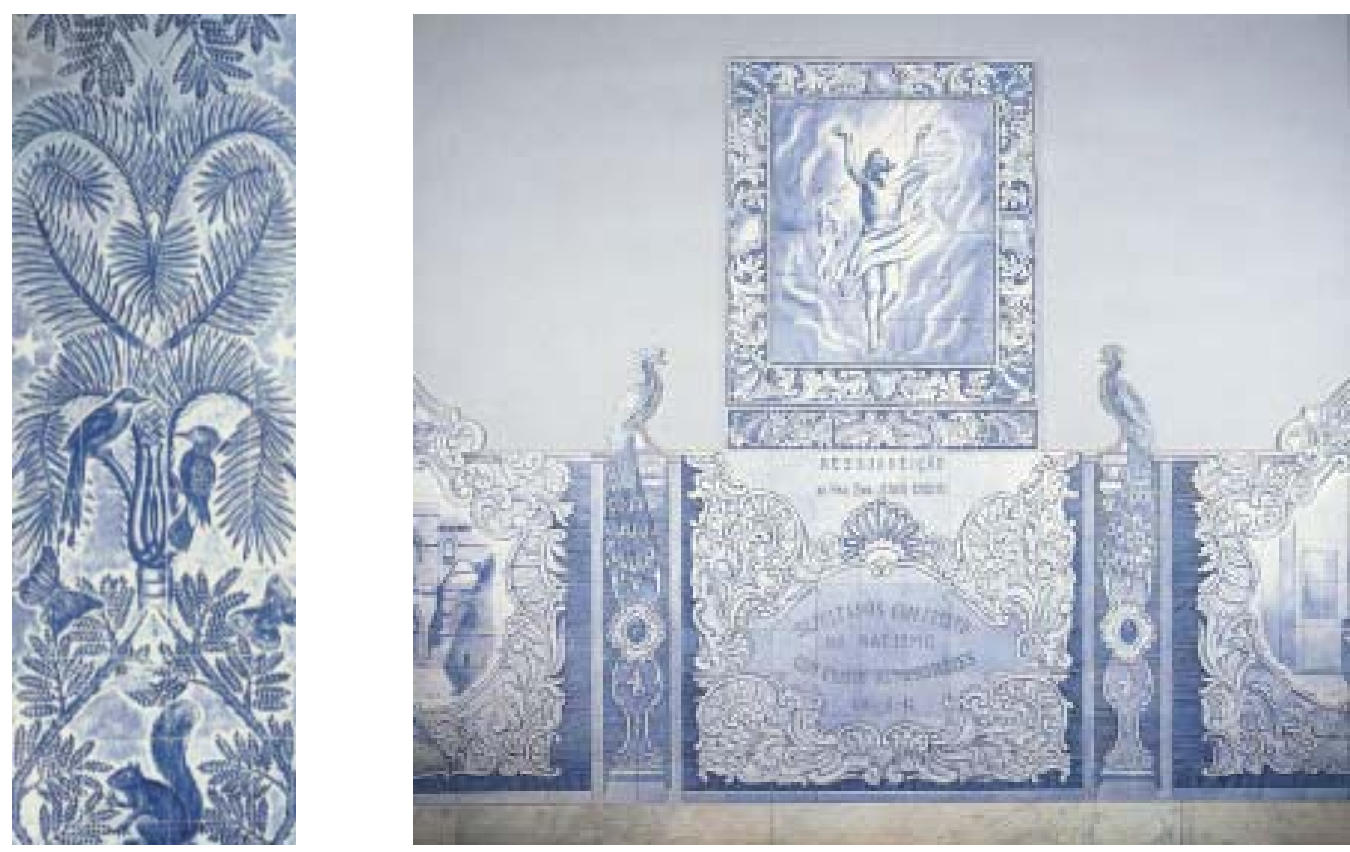

42. e 43. Painéis de Antônio Paím

Igreja Nossa Senhora do Brasil, São Paulo.

Fonte: MORAIS, 1988, p.25

em Perdizes, onde hoje localiza-se a Pontifícia Universidade Católica de São Paulo. Dizem que estes painéis foram um dos últimos trabalhos do pintor Benedito Calixto, porém, Morais (1988) revela que, na verdade, os painéis são de autoria de Paulo Rossi Osir. Segundo Sorgenicht Filho ${ }^{10}$ (1984 Apud LEMOS, 1984), os azulejos produzidos no ateliê de seu pai eram pintados à mão, inclusive os padrões de tapete e as barras decorativas. Eram usados, de preferência, azulejos alemães brancos vidrados, sobre os quais pintava-se com pincel a decoração desejada, enquanto que na Europa usavam decalques aplicados na primeira queima.

Antônio Paím Vieira foi o artista que criou e pintou os painéis para a igreja de Nossa Senhora do Brasil, igreja neocolonial, localizada na Avenida Brasil, na capital paulista. Paím queimou esses azulejos no seu próprio forno à lenha, no quintal de sua casa. A igreja de Nossa Senhora do Brasil é um belo exemplo onde os azulejos ocupam quase todos os espaços disponíveis: estão na capela-mor, altares laterais, corredores, portas e fachadas do edifício. Paím é considerado um artista nacionalista, por retratar nos seus trabalhos temas de raízes nacionais, como a cultura indígena, o folclore, a poesia, a flora, a fauna e os tipos brasileiros (MORAIS, 1988).

Apesar da atuação de Ricardo Severo e Victor Dubugras, o neocolonial desenvolveu grande importância histórica no Rio de Janeiro e não em São Paulo, devido ao médico, crítico de arte e teórico José Mariano Filho, que foi o grande defensor e incentivador do neocolonial na

${ }^{10}$ SORGENICHT FILHO, Conrado (1984). Conrado Sorgenicht Filho [Depoimento] . Apud LEMOS (1984). 
capital do país. Com seu árduo trabalho, sua paixão, dinamismo e alto poder aquisitivo, divulgou e fez prosperar o neocolonial no Rio de Janeiro.

O movimento neocolonial teve grande importância para o contexto brasileiro "... a arquitetura neocolonial foi o símbolo de uma tomada de consciência nacional, que a seguir iria se desenvolver e dar um caráter particular às realizações brasileiras" (BRUAND, 2002, p.58). Nas palavras de Segawa (2002, p.39), “... o principal aporte da postura neocolonial foi a introdução do contraponto regionalista - a busca de uma arquitetura identificadora da nacionalidade - como fator de renovação".

Nos anos 30, o neocolonial coexiste com o novo estilo Art Déco. O neocolonial vai aos poucos sendo menos produzido, juntamente com os painéis decorativos de azulejos, que também vão sendo esquecidos, entrando em desuso. Restaram apenas pequenos quadros azulejados, em alguns alpendres com motivos sacros ou paisagens saudosistas da terra distante, uma teimosia de portugueses e espanhóis.

\section{o azulejo como revestimento cerâmico para fachadas}

Não se pode dizer que o uso do azulejo tenha desaparecido totalmente em diversos períodos artísticos e arquitetônicos. Os estilos muitas vezes se misturam e coexistem durante anos, o mesmo acontece com o uso do azulejo. Pelo que foi analisado e estudado até agora, podem-se identificar alguns motivos pelos quais houve períodos onde o azulejo foi mais usado e outros onde foi menos usado. O fator econômico não entra como resultante na escolha do azulejo como material de revestimento de fachadas. No período Colonial os azulejos eram fabricados em Portugal e trazidos de navio, época na qual alcançaram custos elevados, mesmo assim foram usados em abundância, com todo o requinte e qualidade.

A questão da higiene e limpeza contribuiu para a proliferação do uso de azulejo nas fachadas. As fortes chuvas influenciaram a adoção dos azulejos como revestimentos de fachadas. Nas longas estiadas o pó se acumula nas frontarias, escurecendo a tinta do revestimento. Mas nas paredes revestidas de azulejos isso não ocorria, pois, eram lavadas pelas chuvas. Nota-se também a economia conseguida com os azulejos exteriores em áreas tropicais, tanto na mão de obra para limpeza, quanto na desnecessidade de freqüentes gastos com pintura das paredes, quando as chuvas desgastam a pintura a óleo ou a caiação, com a umidade e os líquens ajudando a corroer os pigmentos cromáticos escurecendo as paredes (MONTELLO, 1989). 
Segundo Moita (1997), a generalização do uso do azulejo nas fachadas foi permitida também pelo barateamento do material, decorrente da sua industrialização e fabricação em série por processos mecânicos. Em relação à questão da luz, da iluminação ou do reflexo nas fachadas de azulejos, Barata (1986) registra que a luz do nosso país tropical é um elemento próprio, que valoriza o uso dos azulejos nas fachadas:

“...A maior claridade fornecida pelos azulejos tanto pode servir em Portugal como no Brasil, mas devido à luz forte existente normalmente em nosso país, essa atuação da cerâmica vai assumir uma feição mais intensa e particular. O conteúdo de alegria que reveste a intensidade da luz tropical é um elemento próprio que valoriza o uso dos azulejos. A questão da luz é básica nas condições tropicais e sua ligação com a azulejaria é um elemento a ser mais considerado nos estudos da ligação do uso dos azulejoscom o Trópico."

A partir dos anos 1980, foi difundida junto aos consumidores a idéia de que, pelo fato de os azulejos apresentarem absorção de água entre 10\% e 20\%, sua expansão por umidade deveria ser alta e isso explicava os estufamentos e destacamentos que ocorriam em situações de umidade, além do gretamento do esmalte facilmente observado em azulejos produzidos até o início dos anos 1990. Além disso, o azulejo tinha que ser produzido por duas ou mais queimas, o que inviabilizava economicamente 0 azulejo como revestimento para grandes fachadas. Estes problemas fizeram com que os azulejos fossem quase que totalmente substituídos por revestimentos cerâmicos com menores porosidades e produzidos por monoqueima.

Hoje em dia, após a evolução ocorrida a partir dos anos 1990 no setor de revestimentos cerâmicos, o azulejo pode ser produzido por uma única queima (por isso a terminologia "monoporoso" utilizada pelos fabricantes), diminuindo seu custo de produção. Além disso, o desenvolvimento científico e industrial proporcionou melhor qualidade da queima que permite a produção de placas porosas, como 0 azulejo, com expansões por umidade abaixo de $0,6 \mathrm{~mm} / \mathrm{m}$. Essa evolução do processo industrial aliada às vantagens, principalmente 0 menor peso e a excelente aderência que o azulejo proporciona com as argamassas colantes do tipo AC II (indicada para azulejos para exteriores), AC III e ACIII-E (indicadas para azulejos exteriores onde requer maior aderência e flexibilidade), deveria ser motivo para que as empresas produtoras investissem em design de azulejos para fachadas. 
${ }^{11}$ Placas ou peças cerâmicas: são placas feitas de argila e outras matérias primas inorgânicas geralmente utilizadas para revestir pisos e paredes. São conformadas por extrusão ou por prensagem, em seguida são secadas e queimadas à temperatura acima da incandescência. São incombustíveis e não são afetadas pela luz. Podem ser esmaltadas ou não esmaltadas. In: Guia para revestimentos cerâmicos. Versão completa. Disponível em: www.eesc.usp.br/sap/docentes/ sichieri/ceramica/index.htm. Acesso em: abril de 2006

A maior aderência mecânica dos azulejos nas argamassas colantes pode ser um grande aliado para se evitar o destacamento, que é uma das patologias mais freqüentes e graves que ocorrem em fachadas revestidas com revestimentos cerâmicos com menor porosidade.

Atualmente, apesar de todo o avanço tecnológico que facilita a produção e torna o azulejo um produto altamente econômico e viável, ele não é explorado como deveria, nem usado em revestimento de áreas externas, pois os gostos e as tendências atuais apontam para o uso de outros materiais como o porcelanato e o mármore, que são produtos que alcançam altos custos de fabricação e instalação em revestimento de áreas externas.

O azulejo como revestimento cerâmico de fachadas de edifícios ainda é utilizado no Brasil, embora sua produção esteja basicamente restrita à forma artesanal, o que encarece 0 produto e faz com que este seja aplicado apenas em pequenas áreas. Os fabricantes precisam ser sensibilizados de que este produto de relevância histórica para a arquitetura brasileira merece um design moderno que o coloque na vanguarda da produção de revestimentos para fachadas, com excelentes vantagens de peso e aderência frente a outros produtos cerâmicos disponíveis hoje no mercado, tais como mármore e porcelanato.

\section{Indústria de revestimentos cerâmicos no Brasil}

Aqui trataremos o azulejo como um tipo de revestimento cerâmico ou placa cerâmica ${ }^{11}$. Os tipos de revestimentos cerâmicos são nomeados como: porcelanato, grés, semi-grés, semiporoso, poroso e monoporoso (azulejo).

O Brasil é o segundo maior mercado de revestimentos cerâmicos. Os produtores brasileiros estão aumentando suas participações no mercado mundial, atingindo o quarto lugar em exportação. A produção é concentrada nos Estados de Santa Catarina, no pólo cerâmico de Criciúma e em São Paulo, no pólo de Santa Gertrudes.

No Brasil, a produção industrial de revestimentos cerâmicos em grande escala começou após a Segunda Guerra. As empresas pioneiras na produção contínua foram a Klabim, no Rio de Janeiro, a Matarazzo, em São Paulo e a lasa, no Nordeste. A mudança para a produção industrial ocasionou mudanças também no caráter do material. Os revestimentos cerâmicos, antes usados apenas pela elite, passaram a ser usados também por todas as classes sociais, inclusive em projetos de habitação popular. Com o Sistema Financeiro de Habitação, por volta dos anos 60, 
ocorreu um aumento da produção nas indústrias de material de construção. Foi nessa época que surgiu o pólo industrial de Mogi Guaçu, em 1970, o de Criciúma e nos anos 80 o de Santa Gertrudes.

No Brasil, o setor cerâmico é dividido em segmentos que se diferenciam pelos produtos obtidos e pelos mercados em que estão inseridos. Os principais segmentos do Setor Cerâmico são: Cerâmica Estrutural (vermelha), Revestimentos Cerâmicos (pisos e azulejos), Matérias Primas Naturais, Refratários, Cerâmica Técnica Especiais, outras; Sanitários; Louça de Mesa e Adorno; Fritas, Vidrados e Corantes; Matérias Primas Sintéticas; Cerâmica Elétrica; Equipamentos para Cerâmica e Abrasivos.

Sendo o setor de Revestimentos Cerâmicos um dos mais importantes, apresenta crescente desempenho tecnológico e é o segundo maior colocado por valor de produção (BUSTAMANTE e BRESSIANI, 2000). Os principais fabricantes mundiais do setor cerâmico estão com unidades de fabricação ou montagem instaladas no país. Mesmo assim, alguns equipamentos ainda são importados.

Dos países produtores de revestimentos cerâmicos, o Brasil é um dos que reúnem as maiores possibilidades de desempenhar um papel cada vez mais importante no cenário mundial. É interessante destacar alguns dos aspectos importantes com relação à indústria brasileira de revestimentos cerâmicos:

"1) o mercado interno é hoje, depois da China, o maior do mundo; 2) a capacidade instalada é maior do que a demanda de mercado interno atual e deverá continuar crescendo nos próximos anos; 3) a melhoria significativa da qualidade e eficiência dos processos produtivos ocorrida principalmente nos últimos anos; 4) praticamente todos os fornecedores internacionais de equipamentos e insumos estão presentes e interessados no crescimento da produção; 5) a adoção nos últimos anos de uma política comercial internacional mais agressiva cujos resultados já podem ser apreciados no significativo crescimento da participação brasileira no mercado norte-americano; 6) a modernidade de considerável parte das empresas assim como os constantes investimentos com essa finalidade; 7) a localização geográfica. Por outro lado, muitas vezes o tamanho do mercado interno (393,3 milhões de $m^{2}$ em 2000) e as freqüentes flutuações da economia interna (principalmente as variações do câmbio) dificultam maiores esforços para a expansão das exportações" (BOSCHI, 2002, p.10). 
A indústria brasileira de revestimentos cerâmicos pode ser subdividida, segundo 0 processo produtivo, em dois grandes grupos, via úmida e via seca. A maior parte das empresas que trabalham por via seca está concentrada na região de Santa Gertrudes, no Estado de São Paulo. A capacidade produtiva dessa região já ultrapassou os limites do mercado local, uma parte cada vez maior da produção é transportada via terrestre para outras regiões do país. Com este processo, o frete acaba encarecendo os produtos e várias empresas começaram a se organizar no caminho da descentralização da produção. Porém, com a descentralização, perdem duas vantagens competitivas, a proximidade da matéria-prima e a proximidade dos serviços de apoio.

Os produtos via seca do pólo de Santa Gertrudes têm como principais vantagens competitivas o custo de produção inferior; a proximidade das matérias primas e a proximidade do maior centro consumidor da América Latina (a grande São Paulo e cidades próximas). Os avanços na melhoria da qualidade dos produtos tiveram importante colaboração entre fornecedores de insumos (equipamentos, esmaltes, etc.) ligados às empresas italianas e espanholas e os técnicos das empresas. A competição no setor da indústria de revestimentos cerâmicos é baseada na inovação em termos de processos produtivos, produtos, marketing e serviços pós-venda. Esta inovação parte das duas principais indústrias fornecedoras, os fornecedores de bens de capital e os fabricantes de colorifícios.

Os fabricantes juntamente com os técnicos dos colorifícios e fornecedores de equipamentos, adaptam a produção por via seca às características das argilas da região, obtendo ótimos resultados. Nos últimos anos, os produtos produzidos por via seca vêm se igualando, em termos de qualidade, aos produtos de via úmida, além de poderem ser comercializados a preços menores, devido aos menores custos de produção. No entanto, estes bons resultados estão limitados à utilização das argilas da região, até hoje não se conseguiu o mesmo resultado com matérias-primas de outras regiões, o que dificulta a implantação da via seca em outras localidades.

Os fornecedores de bens de capital estão localizados na Itália. Desde o final dos anos 70, os fabricantes de máquinas inovaram a produção com a moagem a úmido, prensas de alta tonelagem, fornos de rolamentos e instrumentos de controle cada vez mais sofisticados. A moagem a úmido permitiu melhor controle da massa que entra na prensa, homogeneizando a qualidade do produto. A melhoria na prensa seguiu efeito parecido. Os rolamentos nos fornos encurtaram 0 
processo de queima, ampliando a qualidade, reduzindo os custos de produção e melhorando 0 controle do processo de queima. O processo de monoqueima foi outra inovação importante.

Os produtores de colorifícios, hoje dominados pelas empresas espanholas, desenvolveram a sua competência no domínio da tecnologia de processo produtivo, permitindoIhes prestar serviços de assistência técnica aos produtores. A competência essencial em design que antes era do produtor de revestimentos cerâmicos está sendo do produtor de colorifícios, que oferece o modelo da peça utilizando o esmalte que produz e ainda assessorando no ajuste da linha de produção. Design está fortemente ligado à engenharia de materiais. Os produtores de colorifícios possuem grandes departamentos internos de design. A grande competição no setor fez com eles ofereçam novos designs de graça para seus consumidores, criando demanda para seus produtos.

No Brasil, os fabricantes espanhóis de colorifícios têm forte presença, com representação comercial ou produção com importante papel no suporte aos produtores de revestimentos cerâmicos, tanto em design, como na solução de problemas no processo produtivo (SEIBEL, MEYER-STAMER e MAGGI, 2001).

Os mesmos autores destacam ainda que, o revestimento cerâmico é um bem de consumo durável. Durante sua vida, uma pessoa irá adquirir revestimento cerâmico menos freqüentemente do que um carro ou uma televisão. O negócio de revestimentos cerâmicos faz parte da indústria de materiais de construção. A sua estrutura de comercialização tem aspectos que devem ser considerados como: quem é o consumidor e quem irá atender esse consumidor. A indústria de revestimentos cerâmicos tem como característica marcante a constante atualização, fenômeno comum na indústria de alta tecnologia, mas se torna surpresa num sub-setor da indústria de materiais de construção. Os lançamentos de novos produtos são anuais, ou até semestrais, devido às mudanças na moda, surgindo novas cores, estruturas de superfícies, conceitos de design. 0 ciclo de vida de muitos produtos é relativamente curto, apenas de dois ou três anos.

A diferenciação de produto tem sido bem procurada. Uma empresa pode expandir seu espectro de produtos bem além da diferença - rústico x brilhante. Existe uma produção bem dinâmica de peças especiais, criando enorme variedade de opções: design dedicados a mercados externos específicos, refletindo diferenças de países em termos de estilo e cor, diferenças regionais, além dos lançamentos de revestimentos para aplicações em fachadas, lugares públicos, etc. (SEIBEL, MEYER-STAMER e MAGGI, 2001). 
A indústria de revestimentos cerâmicos utiliza grande variedade de matérias-primas, todas encontradas na natureza, constituídas pelos materiais argilosos e os não-argilosos. Os materiais argilosos são de vários tipos e composições. Na produção da massa (barbotina), geralmente, são usadas misturas de diversos tipos e características diferentes que resultam na composição desejada, enquanto que os materiais não argilosos são usados em misturas com argilas, quando estas não os contêm, com finalidade de formar o corpo cerâmico ou promover a fusão da massa. Os compostos minerais normalmente usados são quartzo, feldspato e calcário.

Na produção dos esmaltes, usados nos acabamentos do revestimento, empregam-se outros componentes minerais que formam seus três componentes básicos: elementos fundentes (chumbo, magnésio, cálcio e sódio), elementos opacificadores e refratários que determinam as propriedades finais do vidro (estanho, zinco, zircônio e alumínio) e elementos vítreos, que formam o corpo do esmalte (quartzo e feldspato).

Os produtos acabados geralmente são classificados em A, B, C e D, de acordo com os defeitos encontrados. Essa classificação é feita eletrônica e visualmente e influem no preço. Os produtos B, C e D são, respectivamente, 15\%, 40\% e 60\% mais baratos que os produtos $A$.

As empresas produtoras de revestimentos cerâmicos vêm aumentando sua capacidade produtiva, incrementando processos e produtos e melhorando, significativamente 0 atendimento pós-venda. Simultaneamente, as empresas produtoras de argamassa colante, que são mais recentes e com menor poder, também vêm se desenvolvendo, aumentando a oferta de produtos, apresentando argamassas diferentes para diversos tipos e usos e difundindo o método de assentamento com argamassa colante para substituir o método convencional.

De maneira geral, as indústrias de revestimentos cerâmicos, de argamassa colante e de rejuntamento encontram-se em aperfeiçoamento, possuem fatores positivos, mas precisam ajustar pontos para melhoria da estrutura e desempenho. Apesar de se mostrarem interessadas na qualidade e desempenho de seus produtos, não demonstram preocupação em relação ao sistema de revestimento cerâmico. No entanto, o perfeito casamento do sistema é que garante 0 desempenho eficiente de seus produtos. A integração destas três indústrias ó o ponto fundamental para o desenvolvimento de todo o setor (LIMA, 2003). 


\section{Processos de produção}

No processo produtivo do revestimento cerâmico as matérias-primas são submetidas a uma seqüência de operações para adquirir as propriedades requeridas no produto final, através de transformações físicas e químicas. Caridade (2000, p.85) resume estas etapas da seguinte forma: "inicialmente, as matérias-primas minerais são pesquisadas e exploradas, passam por um processo e moagem (a seco ou a úmido) de acordo com o processo de fabricação, adquirem uma forma definida na conformação, os materiais são secos, passam ou não por um processo de decoração, recebem o tratamento térmico e acabamento".

Após a Segunda Guerra Mundial a indústria de revestimentos cerâmicos, como sabemos, teve notável desenvolvimento, porque permitiu a expansão no uso desses materiais em vários tipos de construções, principalmente, devido às suas características de isolamento à água, facilidade de limpeza e assepsia. O revestimento cerâmico tornou-se sinônimo de higiene e passou a ser exigido por vários códigos da construção civil, principalmente em ambientes de banheiros e cozinhas residenciais, de restaurantes, lojas, indústrias e hospitais.

Nos anos 90, no mercado interno houve uma redução na produção e venda de azulejos em contraste com um aumento na produção e venda de pisos cerâmicos. Alguns fatores foram responsáveis por este ocorrido, como por exemplo: a retração do mercado interno, no início dos anos 90 levou ao fechamento de diversas fábricas de azulejos; surgiu novo mercado para pisos, devido ao desenvolvimento tecnológico em design, ampliando o uso do produto em salas, escritórios, livings, fachadas, restaurantes, shoppings, etc.; fábricas tradicionais diversificaram sua produção passando a produzir pisos intensamente e implantação de novas plantas industriais com produção de pisos direcionada para o mercado externo.

No setor de revestimento cerâmico a qualidade técnica do produto, cada vez mais importante, é geralmente, indicada conforme as normas técnicas internacionais. $\mathrm{O}$ atendimento às normas pode ser representado através de um Selo de Qualidade, emitido por um organismo certificador, que no Brasil é o CCB - Centro Cerâmico do Brasil. Este selo vem diferenciando as empresas certificadas e as não certificadas.

No nosso país, a produção de revestimentos cerâmicos pode ser classificada de acordo com o processo de preparação da massa, via úmida e via seca. O processo de via úmida segue as etapas: a) mistura de várias matérias-primas (argilas, materiais fundentes, talco, carbonatos, etc.), que são moídas e homogeneizadas em moinhos de bola, em meio aquoso; b) secagem e 


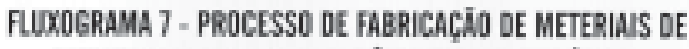 REVESTINENTO (PLACAS CERÃMICAS) POR VIA ÜMIDA}

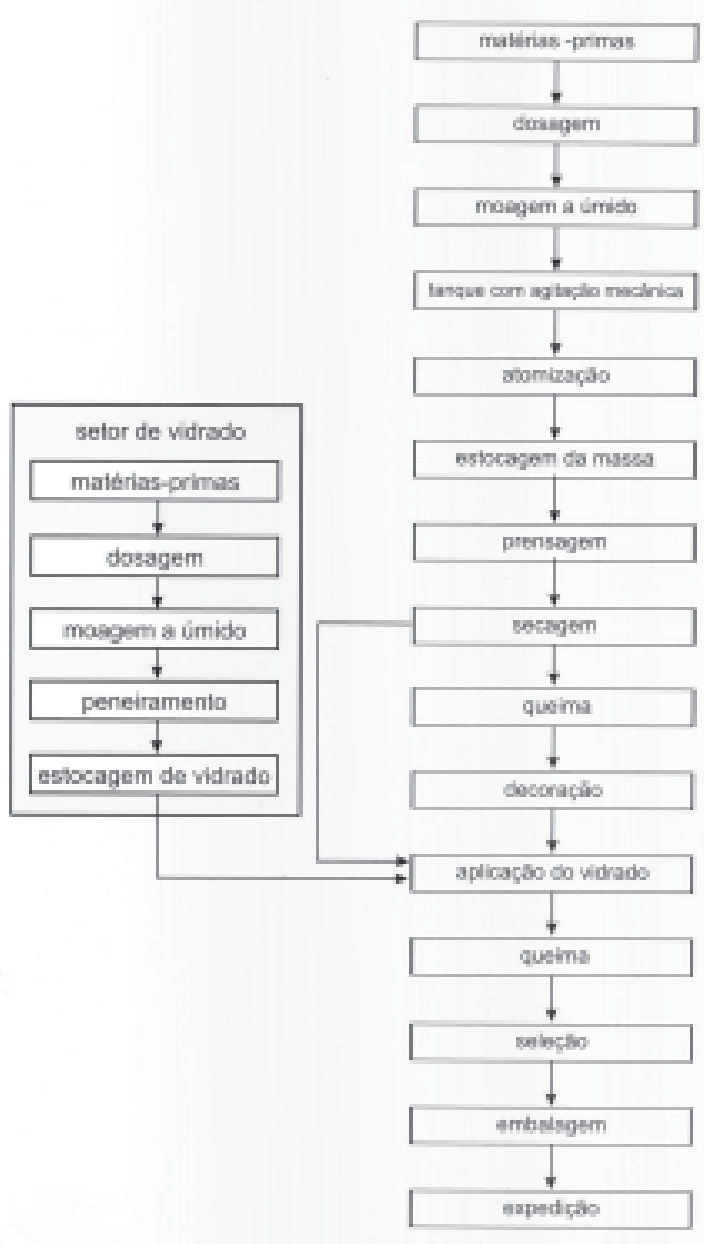

(B)
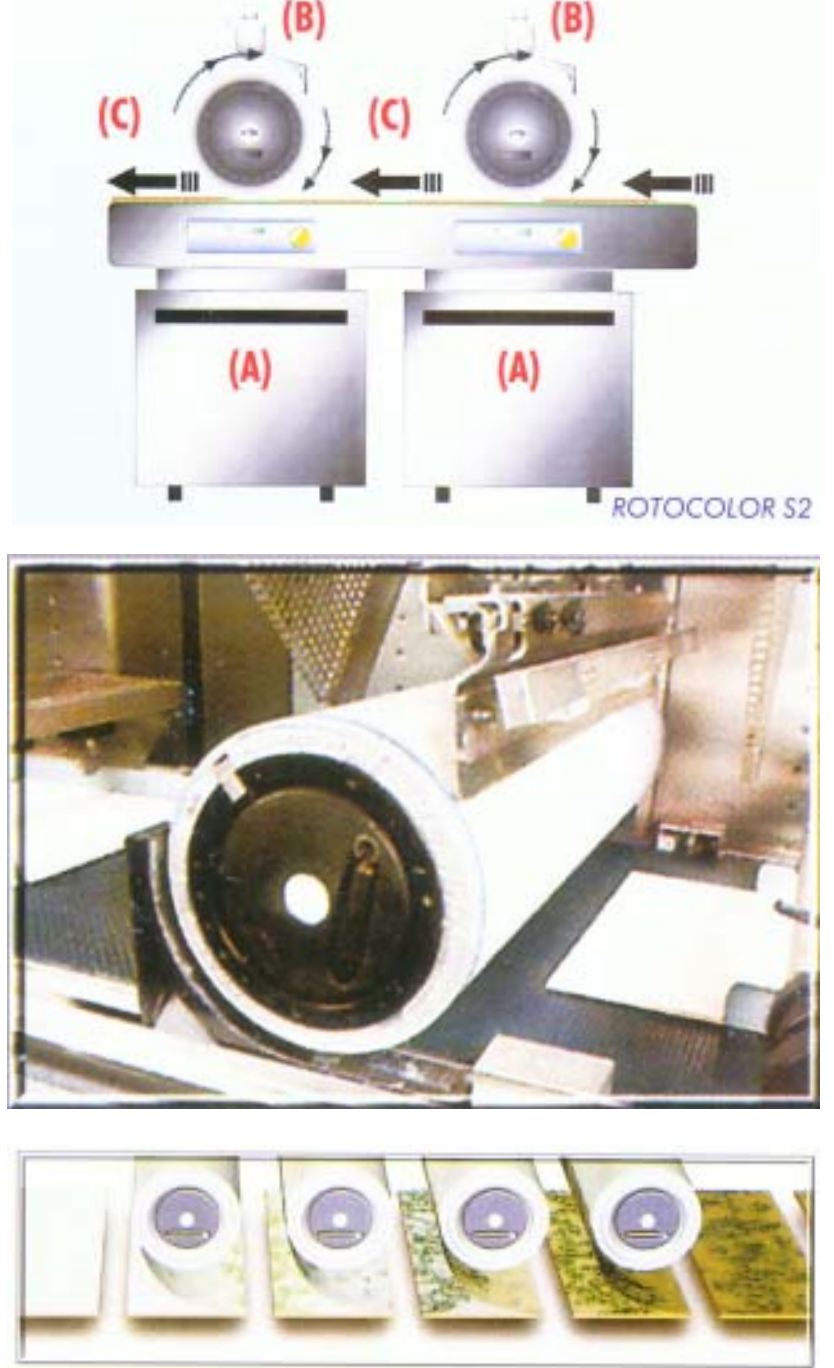

44. Processo de produção por via úmida. Fonte:www.abceram.org.br 45. 46. e 47. Rotocolor MSP. Fonte: ROTOCOLOR granulação da massa em spray-dryer (atomizador); c) conformação, decoração e queima. A escolha das matérias-primas busca dar cor branca ou clara aos produtos (biscoito ou suporte). Esse tipo de processo é mais usado na região sul, no pólo cerâmico de Criciúma (SC), no Paraná e em São Paulo, nos pólos de Mogi-Guaçu e da grande São Paulo.

O processo de via seca usa apenas argilas vermelhas, onde a produção das matériasprimas é feita pelas operações de lavra, secagem e moagem a seco, seguindo para os processos posteriores. Esse processo é mais usado pelas empresas do pólo de Santa Gertrudes. Estima-se que o processo via seca seja aproximadamente $30 \%$ mais econômico que o por via úmida.

Existem, basicamente, três tipos de queima. No processo de monoqueima são queimados, ao mesmo tempo, em temperaturas elevadas, normalmente acima de $1.000^{\circ} \mathrm{C}$ a massa argilosa, 
que constitui o suporte e 0 esmalte. Esse processo gera maior ligação do esmalte à base, conferindo-Ihe melhor resistência à abrasão superficial, resistências mecânica e química e absorção de água relativamente baixa.

A biqueima é um processo mais obsoleto, através do qual é queimado apenas o esmalte, pois a base já foi queimada anteriormente. Apresenta desvantagens em relação ao processo anterior, tais como: maior consumo de energia, ciclo de produção maior e mão-de-obra intensiva; e, finalmente, a $3^{a}$ queima permite a obtenção de alguns efeitos especiais, como pinturas metálicas, alto-relevo, que não são possíveis de se conseguir com temperaturas elevadas. Permite também decorar pequenas quantidades de peças sem variações na tonalidade.

Em relação à tecnologia utilizada, as principais indústrias brasileiras estão no mesmo nível das maiores empresas da Itália e da Espanha. Os equipamentos da linha de produção são de última geração, importados ou montados no Brasil por filiais de empresas estrangeiras (GORINI e CORREA, 1999).

\section{Técnicas de decoração}

Muitas vezes a qualidade de uma peça cerâmica é determinada pela correta exposição ao fogo, pois o mesmo refuga ou aprova o produto, atuando como agente natural de seleção. 0 processo de biqueima é utilizado dependendo do tipo de composição da massa. Como o próprio nome diz, é caracterizado por duas queimas: a primeira, para o biscoito, dura cerca de 40 horas e à temperatura aproximada de $1.050^{\circ} \mathrm{C}$ e a outra, para queimar o vidrado ou esmaltação, é mais rápida e com temperatura mais baixa $\left(950^{\circ} \mathrm{C}\right)$.

Atualmente as indústrias cerâmicas associaram esses dois processos da biqueima na monoqueima, que consiste na prensagem da argila e a decoração da peça ainda crua. São feitas até três serigrafias (decoração) na base da superfície da peça.

A terceira queima é um processo mais simples, onde são inseridos novos elementos decorativos sobre a superfície da peça. No Brasil, surgiu em meados dos anos 60 , com a finalidade de resolver problemas produtivos, ou seja, encobrir defeitos em revestimentos de segunda qualidade.

Atualmente, os processos decorativos usados na indústria de revestimentos cerâmicos são: a) Serigrafia: comparada às outras, esta técnica oferece baixos custos, flexibilidade em relação 
à quantidade de tinta aplicada, combinação de cores e aplicação a seco de alguns produtos como vidro granulado. Possibilita dimensões variadas, entre 05 a $2 \mathrm{~mm}$; b) Decoração a pincel: foi muito usada em tempos mais antigos, mas ainda é aplicada, principalmente em pintura de painéis e peças especiais; c) Decalcomania: é um processo feito através do decalque. O desenho, o motivo é serigrafado em um tipo de papel especial e depois é passado para a placa cerâmica para ser queimado, é um processo caro e manual. É usada apenas em peças não planas. Não se encontram grandes produtores de decalques cerâmicos em nosso país, não sendo muito utilizada, atualmente; d) Ocografia: é uma nova tecnologia de impressão que está sendo muito usada no setor cerâmico, também conhecida como Rotocolor. Nesse processo é usado um cilindro de silicone especial em cuja superfície as aberturas que definem o desenho são feitas com um sistema de laser. Oferece vantagens tais como: velocidade na decoração, diminuição de ruptura de ângulos e quebra de peças. O funcionamento é bem diferente da serigrafia. A tinta é colocada num tanque, sob os cilindros, de onde é bombeada para cima e colocada perto da espátula, ela entra pelas cavidades dos cilindros e é liberada no azulejo que é transportado por uma esteira em movimento. A espátula serve para limpar, ou seja, recolher a tinta excedente na superfície do cilindro. 


\section{o azulejo na arquitetura moderna brasileira}

Na segunda vinda ao Brasil, em 1936, Le Corbusier propagou a questão da síntese das artes, incentivou o sistema no qual a arquitetura relaciona-se com as artes plásticas. Seguindo os ensinamentos do mestre, os arquitetos começaram a trabalhar em parcerias com artistas plásticos; a escultura e a pintura são as artes mais utilizadas na arquitetura moderna, os painéis assumiram certo destaque, ou melhor, começaram a ser pensados juntamente com a obra arquitetônica, em suas particularidades e lugares específicos.

Alguns arquitetos e artistas plásticos tiveram papel significativo na integração artearquitetura, ou na síntese das artes. Por algumas razões o emprego do azulejo se justifica em determinados ambientes, como podemos observar em alguns exemplos, nos quais os painéis se relacionam com 0 ambiente, ajustam e complementam a arquitetura.

\section{Arte e política no Brasil (1930-1950)}

Na Semana de 22 a arte atraiu a atenção do público pelo estranhamento, pelo escândalo. Após 1929, os objetivos e práticas dos artistas se alteraram, ao invés de confrontar, tentavam conquistar o público, principalmente no Rio de Janeiro (por ser a capital, sede do poder político) e em São Paulo (pela produção cafeeira) por serem mais diretamente atingidos pela crise econômica internacional. As questões econômicas acabaram influenciando as relações entre os dois estados que visavam à conquista da liderança nacional.

A crise gerou problemas econômicos e sociais, abrindo espaço para reconsiderações, inclusive na área cultural. Artistas, escritores, intelectuais se reuniram e criaram sociedades e clubes, buscando aperfeiçoamento no campo cultural, estético e de formação. As fronteiras em relação ao papel da arte foram, então, ampliadas, foi uma etapa significativa na qual a arte se tornou mais sociável. "A arte moderna quer conquistar o transeunte urbano, convivendo com o dia-a-dia e tornando-se rotina, o que consideramos um aprimoramento, já que ganha em maturidade" (LOURENÇO, 2001, p.18). Antes, os artistas menosprezavam de maneira aristocrática, 
os que não os aplaudiam, a partir de 1930, surgiram novos ideais, passaram a conduzir, sair na frente, romper com a continuidade, aprimorar e almejar o estatuto de 'educador'.

A revolução de 30, a crise mundial e o nazi-fascismo na Europa enriqueceram o debate sobre o futuro do país. O moderno começava a ser reconhecido como projeto de vida possibilitado pela vida urbana, industrialização e modernização da sociedade. A arte moderna era a representação do futuro projetado.

Após a derrota paulistana de 32, foi criada a Sociedade Pró-Arte Moderna - SPAM, que reunia artistas, intelectuais e representantes da elite. A SPAM realizou não só grandes bailes de carnaval, festas e saraus musicais, como também exposições dos acervos particulares dos membros da sociedade. Também em 1932, Flávio de Carvalho se associou a um grupo de pessoas e fundou o Clube dos Artistas Modernos - CAM, que organizava exposições e conferências seguidas de debates conduzidos por jovens intelectuais brasileiros. Tanto o SPAM como o CAM tiveram curta duração: em 1934 não existiam mais, por falta de recursos, desorganizações, crescente desinteresse de seus associados e também em conseqüência da ação repressiva do governo Vargas. Os dois grupos tiveram como papel principal divulgar a arte moderna, produzir geração de críticos, despertar a curiosidade e formar um público entusiasta de novidades. Contudo, não investiram monetariamente para inserir a arte moderna na cultura paulista (50 ANOS, 2001).

Os Museus de Arte Moderna do Rio e de São Paulo tiveram como modelo o MOMA de Nova York e Nelson Rockfeller, agente e magnata norte americano, como colaborador. O Museu de Arte Moderna do Rio de Janeiro - MAM/RJ foi criado em 1948 e parece ter se diferenciado do MAM/SP pela sua vocação educativa, concretizada pelo serviço de biblioteca e por ateliês abertos ao público (ITAÚ CULTURAL, 2006).

O MAM/SP se juntou aos interesses norte-americanos, promovendo e exibindo o debate entre abstração nacional nascente e a figuração modernista já enraizada no país, ainda que fortalecendo o abstracionismo que se dividia entre o construtivismo geométrico e o abstracionismo informal.

Em 1948, Léon Dégand ${ }^{12}$ chegou ao Brasil e participou de uma série de conferências, primeira atividade do MAM/SP, entre elas, "O que é arte abstrata?" Com o objetivo de preparar o público para a arte abstrata.

${ }^{12}$ Crítico de arte belga, foi diretor

Em 1949 o MAM de São Paulo foi inaugurado e contou com a participação de intelectuais do MAM em 1949. que traçaram o perfil e a política de aquisição e de formação do acervo do museu. A exposição de 
abertura foi organizada por Dégand "Do figurativo ao abstracionismo" teve a participação de 51 artistas, dentre os quais, apenas três brasileiros, Cícero Dias, Waldemar Cordeiro e Samson Flexor, cujos trabalhos já eram abstratos. Ciccillo Matarazzo foi quem financiou a compra das obras para a coleção do museu e promoveu seu crescimento. Ciccillo pertencia a uma nova elite que buscava, através da ação cultural, sua afirmação e prestígio na sociedade e, com sua experiência nos negócios da moderna indústria brasileira pôde dar ao projeto do museu um caráter empresarial (50 ANOS, 2001).

A primeira Bienal ocorreu em outubro de 1951, no espaço onde havia um antigo salão de baile, hoje ocupado pelo Masp, na esplanada do Trianon, na Avenida Paulista. Apesar do empenho de Yolanda Penteado que, com os seus contatos, tornou possível a I Bienal, muitos problemas ocorreram em virtude da inexperiência em realizar exposições desse porte no Brasil. A II Bienal foi inaugurada em dezembro de 1953, abriu a comemoração do IV Centenário da cidade de São Paulo, trinta e nove países foram representados e quatro mil obras foram expostas, "Guernica" de Picasso, dentre elas.

Os anos da década de 1950, época de grandes mudanças bastante significativas para 0 país - tanto nas áreas política e econômica como cultural - caracterizaram-se pelo surgimento de várias propostas de soluções que indicassem o caminho a ser seguido pelo país. 'O que esperamos do Brasil?' Teria sido a pergunta que norteou essa fase (CHAIMOVICH, 2005).

A arte abstrata do século XX foi bastante orientada pelas pesquisas geométricas, associadas ao rigor matemático e à simplificação da forma. No Brasil, o abstracionismo geométrico foi evidenciado por movimentos do concretismo em São Paulo, com o Grupo Ruptura, criado em 1952 por Waldemar Cordeiro e Geraldo de Barros, entre outros; e no Rio de Janeiro, com o Grupo Frente formado em 1954, por alunos de Ivan Serpa.

A arte concreta é herdeira das pesquisas do Grupo De Stijl (O Estilo), de Piet Mondrian e Van Doesburg, que tinha como objetivos a pureza e o rigor formal na ordem harmônica do universo. Herda também, da Bauhaus, a visão social da arte, o ideal de integração da arte na cidade e na vida coletiva. Max Bill foi um dos principais responsáveis pela divulgação da arte concreta na América Latina, principalmente Argentina e Brasil, através da matemática, que considerava o meio mais eficiente para o conhecimento da realidade objetiva, uma obra plástica deveria ser ordenada pela geométrica e pela clareza da forma (ITAÚ CULTURAL, 2006). 
O projeto construtivo no Brasil visava a uma arte não representativa, não metafórica, na busca de uma integração funcional da arte na sociedade, com um esforço constante no sentido de estetizar 0 ambiente social, educar esteticamente as massas. A tendência construtiva se caracterizou por suas relações diretas com a política cultural dos estados, onde o sistema disponibilizou admiti-la como agente de transformação estética do ambiente (BRITO, 1985).

Em 1950, o artista e arquiteto suíço Max Bill, que foi aluno de Gropius na Bauhaus, expôs no Museu de Arte de São Paulo, trazendo contribuições que se tornaram marcos para os futuros concretistas locais. Tanto o projeto russo (construtivismo), como a Bauhaus entendiam a arte abstrata como arte universalmente compreensível, uma vez que era embasada em leis da matemática, ciência exata, onde não há espaço para interpretações pessoais. Os professores da Bauhaus e os construtivistas russos lutavam para que a arte fosse inserida na sociedade e que cumprisse a função de transformação social. Pregavam que a arte abstrata, de cunho geométrico, fosse acessível a todos. Max Bill trouxe para o Brasil essas informações e foi responsável pelo retorno do conceito de arte concreta no pós-guerra. Em 1930, Theo van Doesburg marcou 0 termo "arte concreta". Em 1938 o termo foi retomado por Kandinsky, se referindo à arte abstrata (TEIXEIRA DE BARROS, 2002).

Na I Bienal de São Paulo, de 1951, o prêmio conferido à peça de Max Bill "Unidade Tripartida" demonstrou o entusiasmo pela arte concreta, colaborando na disseminação da tendência geométrica e os conceitos construtivos implícitos. A produção visual concreta revelou alguns pontos como: a exploração da forma seriada, o tempo apresentado como movimento mecânico, as intenções sócio-sensoriais, ou seja, propunha o jogo perceptivo, exercícios óticos belos e significativos em si mesmos, com significados de exploração e invenção de novos sistemas visuais com interesse na capacidade de renovar a possibilidade de comunicação (BRITO, 1985). A arte concreta teve interesse constante pela matemática, tanto como modelo de equacionamento das questões, como ideologia de fundo do trabalho dos artistas.

Para romper com essa fase dogmática e de implantação, surge o neoconcretismo com os choques da adaptação local. Obedecia às prescrições do sistema acerca da atividade cultural, era apolítico, manteve-se em terreno reservado, tímido e desconfiado, com relação à participação da arte na produção industrial. Os artistas neoconcretos podiam ser considerados um tanto quanto amadores, permaneceram no terreno especulativo da arte como prática experimental autônoma, apesar de terem projetado transformações sociais a partir da arte. 
O Grupo Frente formou-se no Rio de Janeiro, de onde saíram muitos dos artistas neoconcretos. Como característica principal do grupo, havia o horror ao ecletismo e a defesa da liberdade de criação, mas apresentava particularidades como, por exemplo, certa desarticulação, possibilidade de se poder pensar a arte seriamente e, ausência de posição produtiva firmada com objetivo de defender a linguagem geométrica.

Segundo o idealismo neoconcreto, seus artistas se mantiveram longe do mercado: não sofreram as influências, não trabalhavam em função das vendas, visando a lucros. Atuaram de maneira marginal, relacionavam-se entre si muito mais como 'homens de cultura' do que como profissionais, existia fluente troca de informações, sem competições. Como movimento construtivo, o neoconcretismo valorizava o momento da concepção do trabalho, em detrimento de sua inserção social. "... o Neoconcretismo foi uma importante manobra da produção de arte brasileira no sentido de conquistar uma autonomia mais ampla frente aos modelos culturais dominante" (BRITO, 1985, p.58).

Desde 1956, na $1^{\mathrm{a}}$ Exposição Nacional de Arte Concreta, começaram as divergências entre os artistas do Grupo Ruptura, paulista, e os reunidos em torno do Grupo Frente, carioca. No programa concreto a arte é afastada de qualquer conotação lírica ou simbólica. O quadro é construído exclusivamente com elementos plásticos planos e cores, e não tem outra significação além dele próprio. A obra de arte evidencia estrutura e planos relacionados, formas seriadas e geométricas, que falam por si mesmas e não é importante a representação da realidade. A respeito do concretismo no Brasil é possível identificar que as investigações do grupo paulista enfatizavam o conceito de pura visualidade da forma, à qual o grupo carioca opõe forte articulação entre arte e vida e ênfase maior na intuição como requisito fundamental do trabalho artístico (ITAÚ CULTURAL, 2006).

Lourenço (2001) acredita que a construção do prédio do Ministério da Educação e Saúde, no Rio de Janeiro constituiu um marco significativo da era Getúlio Vargas. Desejando que sua administração fosse identificada como um governo protetor do povo, Vargas apoiou o ministro Capanema na convocação do grupo de artistas modernos para dar dignidade ao Ministério da Educação e Saúde, que eram questões públicas de maior relevância.

O grande diferencial do período foi o início da Guerra Fria. O mundo inteiro foi forçado a se posicionar entre comunistas e capitalistas, entre a União Soviética e os Estados Unidos. As grandes potências mundiais, inclusive os norte-americanos, tinham interesse em redirecionar 0 
Brasil. Os Estados Unidos viram com desconfiança as atitudes de Getúlio Vargas, tanto de negar o envio de tropas brasileiras para a Guerra da Coréia, quanto o incentivo de atrair indústrias estrangeiras para o país, além de nacionalizar o petróleo e a energia elétrica (CHAIMOVICH, 2005).

Essa situação desencadeou um intenso debate entre de um lado, defensores das tendências estéticas presentes na Semana de 22 tais como produção figurativa, com temas nacionais à luz das vanguardas contra-acadêmicas européias. De outro, a grande singularidade do período foi a implantação do abstracionismo, que entre nós não existia até o final dos anos 40. Em países de domínio norte-americano, aos poucos, foi se afirmando a tendência de interpretar abstração como continuidade do modernismo.

Os meados dos anos 50 foram marcados pela sobrevivência da pluralidade democrática, ameaçada pelas forças oposicionistas internas e pelos interesses dos Estados Unidos. A descentralização do país atingiu o seu auge com o suicídio de Getúlio Vargas, em 1954, com as ameaças de golpes militares e estados de exceção impostos pelo Congresso.

Em 1955 Juscelino Kubitschek de Oliveira foi eleito, tomou posse em janeiro de 1956 e começou a articular alianças políticas que permitiram estabilizar as forças divergentes. Juscelino retomou o projeto nacionalista de Vargas, seu plano desenvolvimentista de trinta metas para cinco anos atuaria em cinco áreas: energia, transporte, alimentação, indústria de base e educação. A construção de Brasília, sua meta síntese foi proposta em 1956. Em 1960 foi inaugurada a Nova Capital. O desenvolvimentismo nacionalista explicitou as forças opostas, caracterizando um momento democrático, onde múltiplas correntes estéticas caracterizaram 0 conceito de arte moderna. Juscelino com seu slogan, avançar o país "50 anos em 5", fez da construção da nova capital um símbolo de sua política desenvolvimentista para o país. Criou condições necessárias para implantar Brasília, instituindo a Companhia Urbanizadora da Nova Capital - Novacap.

O projeto de Brasília se diferencia no panorama brasileiro, e até mesmo internacional, por se preocupar com a integração arte e arquitetura, tanto por parte do seu urbanista Lúcio Costa como por parte do seu arquiteto Oscar Niemeyer. Desde o início da criação de Brasília os artistas foram convocados para colaborar no detalhamento dos projetos arquitetônicos. Com exemplares participações artistas como Alfredo Ceschiatti, Athos Bulcão, Bruno Giorgi, Roberto Burle Marx, Mariane Perreti, entre outros, foram considerados criadores da cidade, juntamente com os arquitetos responsáveis. 
O especial projeto de urbanismo, a qualidade da arquitetura implantada e o acervo artístico integrado tornaram Brasília um conjunto urbano moderno reconhecido como patrimônio cultural da humanidade, pela UNESCO, em 1986.

Com Brasília, o país esperava apagar de vez as mazelas do passado, os resíduos de uma herança colonial, superar o subdesenvolvimento e inaugurar uma era nova e mais justa para o seu povo. Ao mesmo tempo, neutralizar os interesses regionalistas presentes nas capitais anteriores, além de tornar possível a interiorização do país, com a criação de um pólo nacional em uma região até então abandonada. Porém, Brasília perdeu muito de sua força simbólica, devido, entre outros fatores, a duas décadas de governos militares no poder impedindo propostas democráticas no início da década de 60 e consolidando a segregação social. A capital que foi concebida como obra de arte total, comprometida com o progresso na proposta de seus fundadores Juscelino Kubitschek, Lúcio Costa e Oscar Niemeyer (HUG, 1994).

Entre os artistas que contribuíram com a nova capital, Athos Bulcão foi o único que se transferiu definitivamente para a cidade. Sua contribuição foi determinante em projetos de Oscar Niemeyer e de outros arquitetos; suas obras, aliando arte e espaço público, ao longo dos anos, se tornaram referências na paisagem construída da cidade. Em sua trajetória, o artista tem se dedicado intensamente às questões de integração arte e arquitetura, grande parte de seus murais em azulejos revelam total compreensão das questões da intervenção da arte no espaço arquitetônico.

\section{O mural, o painel e a síntese das artes}

Lourenço (1995) faz nítida diferença entre "painel" e "mural". Painel é usado como designativo genérico de pinturas, mosaicos e relevos, geralmente se refere a obras de grandes proporções, feitas em suporte móvel que possibilita deslocamento. É concebido em função de uma determinada arquitetura. Pela escala arquitetônica é uma obra monumental pensada diante de uma situação específica de fluxo, de luz e considerada sua relação com a arquitetura. Há preocupações como: pesquisa das formas, condições existentes, dados sobre o espectador (se é eventual ou não, qual a idade, a que classe social destina). Leva em conta também a velocidade e a altura do apreciador.

O mural, obra feita diretamente no muro, por sua vez, engloba diversas modalidades de pintura como afresco, têmpera e tinta a óleo. O muralismo brasileiro descende do mexicano, mas 
com suas particularidades. No México, o muralismo nasceu da revolução política, enfatizando a figura nativista, símbolo explorado pelo poder econômico, com clara intenção ideológica. Tratase de uma manifestação gloriosa, épica e identificada com princípios históricos. No Brasil, 0 movimento surgiu como desejo de se tornar arte pública acessível a todos os transeuntes, com certo desejo de esclarecer o povo e arrebatá-lo a um ideal. Nos dois países o povo constituiu sempre a temática no muralismo (LOURENÇO, 1995).

Segundo Corona e Lemos (1989) mural é “... a pintura executada em muro ou parede, geralmente de grandes dimensões, tratada de modo particular pelo artista, como complemento de decoração" e painel é "a grande superfície decorada, tanto no interior como no exterior dos edifícios. Neste sentido, o painel pode ser de mosaicos, de pastilhas de porcelana ou de cerâmica".

Não é objetivo deste estudo discorrer sobre a questão da "síntese das artes", que sempre gerou muita discussão. Vale a pena, apenas, pontuar este assunto por estar relacionado ao uso do azulejo na arquitetura. Entre as décadas de 40 e 50, surgem diversas opiniões, entre críticos de arte e arquitetura, artistas e arquitetos, em torno da questão da síntese das artes, da colaboração entre pintores, escultores e arquitetos. Em geral, as reflexões são favoráveis a um trabalho conjunto, mas divergem em questões operacionais, principalmente quanto ao limite das funções; tanto congressos quanto revistas de arquitetura contribuíram para difusão das idéias da integração das artes. Resumindo, grosso modo, podemos identificar duas vertentes: a que defende a influência do artista desde o início do projeto, com liberdade de ampliação de sua atuação, visando a um trabalho sem hierarquias, mas preocupado com a harmonia estética e funcional da arquitetura, tendo como meta o bem estar dos usuários e a outra que, apesar de compartilhar preocupações arquitetônicas semelhantes, proclama a subordinação dos artistas ao arquiteto, com a solicitação da colaboração do artista apenas no final do projeto.

No contexto da integração arte/arquitetura podemos observar um aspecto funcional/ complementar da arte como obra pública, normalmente, um esforço de projeto que abrange desde aspectos simples - como a questão da durabilidade da obra - até os complexos, que dizem respeito à adequação da obra (forma e conteúdo) ao espaço disponível, em função dos efeitos desejados e até do público que passará a conviver com ela. Os desafios da Obra Pública como: temas encomendados, materiais nunca experimentados, grandes espaços, e cumprimento de prazos agradam a alguns artistas como Ademir Martins, que diz que "trabalhar dentro de certos limites obriga o artista ao raciocínio, ao projeto, ao aprendizado" (MARINHO, 1988, p.78). 
A arquitetura considerada e vista como arte maior, juntamente com a pintura, a escultura, a literatura, enquanto que as artes decorativas, onde os azulejos estão inseridos, foram consideradas artes menores. O azulejo como elemento ornamental, definidor de espaços e caracterizador de ambientes, tem andado afastado das correntes representativas da arquitetura contemporânea. Podemos identificar algumas razões que têm direcionado ao desinteresse dos arquitetos em revestir superfícies com azulejos.

O arquiteto, autor do projeto, tem que conciliar o desenho, a modulação e a escala do azulejo com diversas soluções construtivas e variados revestimentos, desde o início da concepção. Um espaço construído com azulejo requer a colaboração estrita com artistas plásticos. As dificuldades enfrentadas, as eventuais retificações, o risco estético e a conquista da aprovação do dono da obra levam os arquitetos a situações prudentes e menos ativas. As exigências diante de tais situações podem levar, muitas vezes, os arquitetos a se afastarem de tais compromissos e comprometimentos, como expõe Pinto (1998). Mas, aos arquitetos, tanto como detentores de cargos públicos, como também influentes na estética urbana (pelas intervenções sobre as quais são solicitados a pronunciar-se) cabem a ousadia e o mérito de alguns projetos de integração arquitetônica em revestimento azulejar.

Para que o revestimento de uma superfície seja mais do que uma aplicação, que vá além de simples adaptação e obtenha uma integração plena, é indispensável que a construção e o revestimento sejam concebidos como uma unidade (PINTO, 1998). Dependendo da finalidade, as condições da integração são várias e variáveis, como por exemplo: revestimento interior ou exterior, localização no rodapé ou pé direito, qualidade e preparação do suporte, dimensão da superfície e padrão e esquema de cores.

O número de revestimentos contemporâneos concebidos simultaneamente com os edifícios que embelezam e protegem são relativamente poucos. Neste estudo são mostrados exemplos de projetos onde algumas variáveis foram atendidas, a coordenação dos arquitetos e a colaboração dos artistas plásticos proporcionaram obras de grande mérito, nas quais o azulejo é o suporte da composição, muitas vezes , desde o início da concepção arquitetônica.

“... o painel conjugado à arquitetura moderna sem dúvida presta colaboração, seja no dinamitar paredes, como observa Le Corbusier, ou cativando o olhar do andante, de certa forma anestesiado pela paisagem cotidianamente vivenciada. Através das soluções bem 
harmonizadas entre painel e arquitetura, a sinfonia moderna ganha a rua e leva seus sonhos para o convívio urbano" (LOURENÇO, 1995, p.268).

Nas questões sobre o redimensionamento dos grandes centros urbanos e a luta contra a deterioração do espaço público, se faz importante considerar a "beleza também necessária", juntamente com a busca de soluções na conjuntura sócio-político-econômica. "O artista deve ser considerado, então, como um agente capaz de redimensionar a visualidade do contexto urbano. Através da arte, busca-se oferecer o bem-estar vivencial e orgulho da cidadania" (AMARAL, 1996, p.9).

Vale lembrar o exemplo do Recife: com base numa sugestão do artista plástico Abelardo da Hora, a Câmara Municipal da cidade do Recife, em 1960, aprovou com vigência em 1961, a exigência de uma obra de arte em todos os prédios particulares com mais de $1.000 \mathrm{~m}^{2}$ e também em todos os prédios públicos, transformando a cidade num canteiro de obras de arte, geralmente, esculturas e painéis. $O$ objetivo desta exigência foi incentivar e valorizar a produção artística local. A experiência foi tão positiva e benéfica que outras cidades, como Fortaleza, aderiram ao mesmo regulamento. Os painéis com revestimento em azulejos enquadraram-se bem dentro dessa política de riqueza decorativa.

No Brasil, onde ainda temos capitais sendo construídas, ou centros urbanos, inclusive os da época colonial, sendo renovados e reformados, faz-se necessário "que possamos instituir um projeto permanente e constante de pensar o espaço e as artes, articular um novo tempo nas relações entre o artista enquanto indivíduo criador, e o meio social dentro do qual ele vive e de cujo contexto participa" (AMARAL, 1996, p.40).

\section{O azulejo como elemento da tradição e os modernos}

Segundo Goodwin (1943), não se notava muita diferença entre os materiais de construção de Portugal e os do Brasil. As características da arquitetura de Portugal foram trazidas para 0 Brasil: as paredes grossas, o pé direito elevado, os espaçosos cômodos, o assoalho de lajes, e os rodapés e juntamente com essas preferências vieram o barroco português e o gosto pelos azulejos.

Tanto pelas viagens ao exterior e principalmente pelas publicações, o Brasil familiarizouse rápido com a Arquitetura Moderna da Europa, não apenas da França, mas também da Alemanha e Itália. Arquitetos estrangeiros vieram para o Brasil já formados, aplicaram idéias e princípios 
que traziam de suas terras, o que também facilitou a proliferação da Arquitetura Moderna no Brasil. Contudo, o Brasil logo achou um caminho próprio. Segundo Goodwin (1943), a grande contribuição brasileira para a nova arquitetura foram noções destinadas a evitar o calor e os reflexos luminosos nos vidros, pelo uso de especiais quebra-luzes externos, os chamados brisesoleil.

Giedion (1956) ressalta que uma das características peculiares da Arquitetura Moderna no Brasil é o tratamento de fachadas. "O Brasil já tinha a tradição de suas fachadas, tão submetidas à pressão do clima tropical, por meio do tratamento estrutural das superfícies planas. Os arquitetos contemporâneos reelaboraram essa tradição, incluindo em seus projetos painéis externos vazados (página 58), cobogós (edifício Bristol de Lúcio Costa, 1948), azulejos utilizados de maneira inovadora, e o brise-soleil" (MIDLIN 2000, p. 17).

Além do brise-soleil, o uso do azulejo no revestimento de fachadas é uma forma pela qual a tradição colonial foi adequadamente adaptada às necessidades na Arquitetura Moderna brasileira.

"O clima geralmente quente e úmido, sujeito a fortes chuvas (a precipitação pluviométrica anual no Rio é de $1.200 \mathrm{~mm}$ ), torna impraticáveis as fachadas menos resistentes, como as de estuque. Le Corbusier nos prestou ainda um outro serviço quando sugeriu que se deveria fazer reviver os azulejos. Não apenas em azul e branco, como era mais comum no passado, mas em todas as cores e nuanças, os azulejos se prestam maravilhosamente para realçar a função não estrutural de superfícies verticais. Seja em motivos repetidos, compostos de uma ou várias peças, geralmente quatro, seja em grandes composições figurativas ou abstratas, os painéis de azulejos trazem consigo uma acentuada conotação de regionalismo. (MIDLIN 2000, p. 34).

Conforme Bruand (2002), o clima foi o fator físico que mais interferiu na arquitetura brasileira. O país apresenta temperaturas elevadas durante o verão. Os arquitetos tiveram como primeiro problema combater o calor e o excesso de luminosidade vindos de insolação intensa. Ele lembra também que o clima no Brasil traz problemas de conservação que interferem na escolha dos materiais de construção. As fortes chuvas e os intensos raios solares estragam rapidamente as pinturas das fachadas, necessitando repintá-las regularmente para preservar a aparência dos edifícios. Utilizar materiais dispendiosos, porém, resistentes à deterioração, na maioria dos casos, é mais econômico o que explica o freqüente uso do mármore e do azulejo no revestimento das 
paredes externas de muitos edifícios, embora este último necessite, em menor grau, de conservação ou manutenção.

A partir de 1930, a era Vargas impôs novo regime que afetou profundamente a vida administrativa- social e econômica do país. Esse período de mudanças refletiu-se, naturalmente, na arquitetura. Surgiram greves e revoltas lideradas pelo movimento estudantil em defesa das novas idéias artísticas, propondo e conquistando a criação de uma escola de arquitetura independente. Criaram-se concursos para projetos arquitetônicos de edifícios públicos que alcançaram grande importância na arquitetura brasileira, trazendo prestígio aos governantes, que viam neles um meio seguro de promoção pessoal; realidade ainda hoje, políticos tiram proveito eleitoral: obras realizadas em uma administração são consideradas "pessoais" e se não forem concluídas até o término do mandato, correm o risco de serem abandonadas pelo sucessor.

No Brasil, tanto o poder público como a iniciativa privada direcionam suas preocupações e produções para a execução de obras que resultem rapidamente em poder, promoção e prestígio junto ao povo, relegam a segundo plano programas de utilidade pública e social, mais necessários a um país de terceiro mundo, por não repercutir na opinião pública. Essa situação serviu para criar melhores oportunidades de trabalho aos arquitetos brasileiros e impulsionar a renovação da arquitetura brasileira ocorrida entre 1935 e 1945 e suas realizações posteriores.

Pelo incentivo dado aos edifícios públicos, mesmo sendo com objetivo de "personalização do poder", Bruand (2002) destaca o nome de dois políticos: o primeiro é Gustavo Capanema, que tem seu nome ligado a um único, porém fundamental edifício, o Ministério da Educação e Saúde, no Rio de Janeiro, o outro é Juscelino Kubitschek, o que mais edifícios construiu nas suas passagens pelo poder, dentre eles o conjunto da Pampulha, em Belo Horizonte e a construção de Brasília.

"As principais características da arquitetura brasileira no século XX, todas elas decorrentes das condições históricas vigentes no país na época, são então as seguintes: predominância da arquitetura urbana, ausência quase total de preocupações sociais, importância fundamental dos edifícios públicos, prioridade às realizações de prestígio, preocupação com a personalização e com o aparato formal, nítido desejo de conceber um arquitetura atual, voltada para o futuro mas sem desprezar os valores do passado, conflitos e tentativas de conciliação entre, de um lado, o apelo revolucionário e o apego à tradição, e, de outro, a sedução por tudo que é estrangeiro e o orgulho nacional" (BRUAND, 2002, p. 29). 
A Arquitetura Moderna brasileira produziu interessantes e importantes edifícios nos quais é notável a presença de painéis de azulejo, apesar de algum excesso ou aplicações vulgares. Mindlin (2000) parece estar certo na sua sugestão de que o desenvolvimento da pintura abstrata e concreta no Brasil estimularia melhor uso desses painéis. Entre outros, citamos como exemplos o prédio do MES no Rio de Janeiro; Igreja, Casino, Casa de Baile e late Clube de Pampulha, em Belo Horizonte e o Conjunto Residencial do Pedregulho, no Rio.

Sobre a arquitetura brasileira da época entre o MES - Ministério de Educação e Saúde e Pampulha, Bruand (2002) escreve que:

"Escultura, pintura mural e azulejos são o complemento quase obrigatório e, em geral, de grande efeito. Mas a arquitetura conserva a liderança; é o arquiteto quem decide qual o papel atribuído ao pintor, ou ao escultor, quem o posiciona no lugar adequado. A participação destes jamais afeta a parte estrutural do edifício, tendo sempre a decoração objetivo de sublimar o caráter de simples vedação das paredes que são portantes" (BRUAND 2002, p.115).

Na década de 40 o azulejo é reatualizado, associado a um sentido de modernidade. No prédio do Ministério de Educação e Saúde são usadas pinturas murais - algumas em azulejos - a fim de compor a idéia da arquitetura como espaço de congregação das artes, idéia sugerida e defendida por Le Corbusier e outros como Gropius, Van der Rohe, Wright.

Desde então, seu uso passa a ser justificado também por Lúcio Costa, principal teórico da arquitetura moderna. O primeiro aspecto em defesa deste material é a sua propriedade plásticofuncional, ou seja, mais adequado para revestir paredes em clima tropical, além de ser refratário ao sol, é mais resistente às chuvas do que paredes pintadas.

Como suporte pictórico, o azulejo faz a parede "desaparecer", tornando-a elemento de vedação e não estrutural. A função estrutural cabe então, aos pilares, "pilotis", seguindo a norma dos "cinco pontos" fundamentais da arquitetura moderna, de acordo com o mestre Le Corbusier (FARIAS, 2001).

Outra justificativa para sua utilização na arquitetura moderna vem da sua tradição construtiva. Com a vinda de arquitetos estrangeiros, surgiu a necessidade de incorporar, e ao mesmo tempo, adaptar alguns usos e costumes estrangeiros às nossas peculiaridades. A arquitetura moderna acompanhou esse esforço de atualização de uma estética nacional com a criação e renovação das nossas raízes. 
Em 1936, Le Corbusier faz sua segunda visita ao Brasil, ao Rio de Janeiro. Entre as recomendações do arquiteto- consultor estavam a valorização dos elementos locais e o emprego de azulejos, que, além do seu caráter funcional de proteção contra a excessiva umidade do clima, possibilita expressão plástica, ou seja, riqueza formal e decorativa. Essas idéias serviram então para superar preconceitos que os arquitetos brasileiros possuíam, ajudando-os a compreender que o uso de recursos do passado é possível se estes se justificam e se adaptam ao espírito das edificações modernas "... o mestre franco suíço demonstrava que o estilo do século XX era internacional, mas que isso não impunha, muito pelo contrário, o abandono das variáveis regionais que assegurassem uma expressão original" (BRUAND, 2002, p. 91).

Le Corbusier preconizou, além do emprego dos azulejos, o de outras artes como pintura e escultura. Sabiamente encorajou a colaboração entre arquitetos e artistas plásticos, o que seria um dos traços marcantes da arquitetura moderna do Brasil. A sede do MES foi premiada com obras de arte de grandes artistas: Cândido Portinari (murais no gabinete do ministro e desenho de azulejos), esculturas de Celso Antônio, Bruno Giorgi e Jacques Lipchitz e jardins de Roberto Burle Marx; seguindo o princípio da integração das artes à arquitetura. O edifício é considerado 0 ponto inicial da arquitetura moderna de feitio brasileiro, embora a construção tenha se arrastado, com dificuldades, entre os anos de 1937 e 1945 (SEGAWA, 2002).

A participação de Le Corbusier no projeto do MES inaugurou uma visão nova na incorporação da arte à arquitetura, propondo que a colaboração dos artistas fosse coordenada pelo arquiteto a fim de desempenhar papel mais adequado à concepção do conjunto, dentro de condições arquitetônicas. Ao cumprir função estabelecida pelo arquiteto, tal como, às vezes, remover uma parede indesejada ou ressaltar um ponto, a participação dos artistas contribuiu para estruturar o espaço.

Além dos painéis para o MES, Portinari realizou também outros painéis em azulejos e, neste campo, o criado para a igreja de São Francisco de Assis, no bairro da Pampulha, em Belo Horizonte, por encomenda de Oscar Niemeyer, nos anos de 1943/44, é considerado sua obra mais importante. O painel, que acompanha a estrutura arquitetônica da igreja na seqüência de quatro arcos, é uma composição de azuis e branco, porém, com forte caráter narrativo, demonstra maior dramaticidade em passagens da vida do santo de Assis. Nota-se forte influência picassiana, uma vez que 0 artista teve contato in loco com a Guernica de Picasso, no Museu de Arte Moderna de Nova York, em 1941 (MORAIS, 1988). 
O interior da igreja também recebe obras de Portinari: um painel ao fundo do altar, em têmpera e outras composições com azulejos; no púlpito, vemos São Francisco falando aos pássaros, enquanto aves voam ao redor e pessoas observam; outro painel, no confessionário e batistério, mostra Jesus nas águas do Rio Jordão, grupos de anjos e pastores com ovelhas. Em conseqüência do clima criado - uma pintura intensamente expressionista, com traços finos, fortes, angulosos e desenho áspero e agressivo - 0 arcebispo mineiro à época, Dom Antônio Cabral, não gostou da pintura e tentou embargá-la. O Serviço do Patrimônio Histórico e Nacional tombou a igreja como patrimônio da nação brasileira, para evitar que a obra fosse destruída ou retirada dali (MORAIS, 1988).

O conjunto residencial do Pedregulho, no Rio de Janeiro, projeto de Reidy, utilizando painéis, é considerado outro exemplo fundamental da arquitetura moderna brasileira, pela sua dimensão social. O ginásio esportivo recebeu na parede externa um painel de azulejos criado por Portinari, cujo tema são os jogos infantis; aparecem meninos pulando carniça, cada um ocupando quatro azulejos. O menino que salta, lembra um espantalho com os braços abertos (lembranças de infância do artista) e tem o rosto redondo, cabelos lisos e traços de oriental, com roupa que parece um quimono ou roupão. Outro menino está com o tronco inclinado. A sensação do jogo, onde há movimentação contínua das crianças correndo e saltando umas sobre as outras, é criada pelo modo como os azulejos foram distribuídos sobre a parede. O fundo tem quatro tonalidades de azul, além do branco, formando jogos de luz e sombra (MORAIS, 1988).

Portinari criou outros painéis azulejados, em obras de Niemeyer como no late Clube da Pampulha ou residências no Brasil e no exterior. Há também um, na fachada da sede da
48.Painel de azulejo de Portinari Igreja de São Francisco de Assis Pampulha, Belo Horizonte, 1944.

49.Detalhe azulejos de Portinari Igreja de São Francisco de Assis Pampulha, Belo Horizonte, 1944.

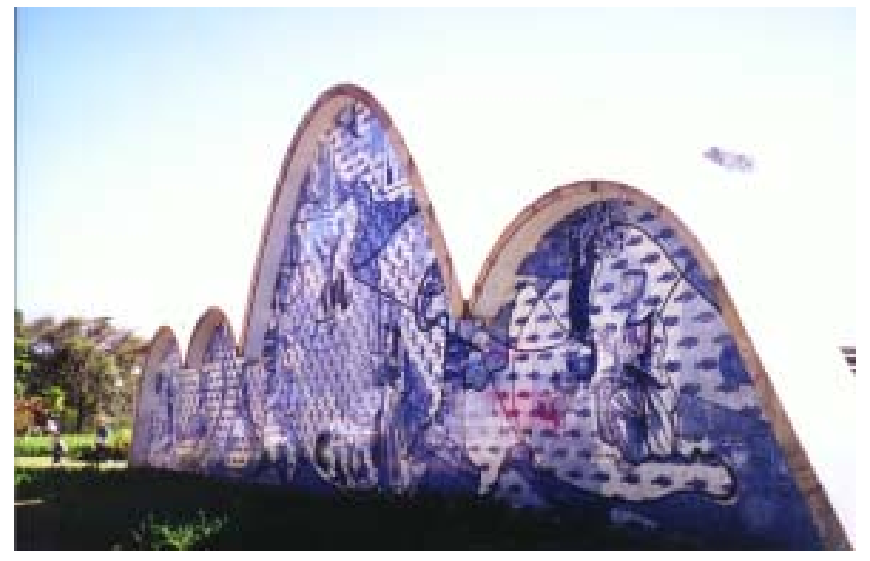

azulejo na arquitetura brasileira: os painéis de athos bulcão

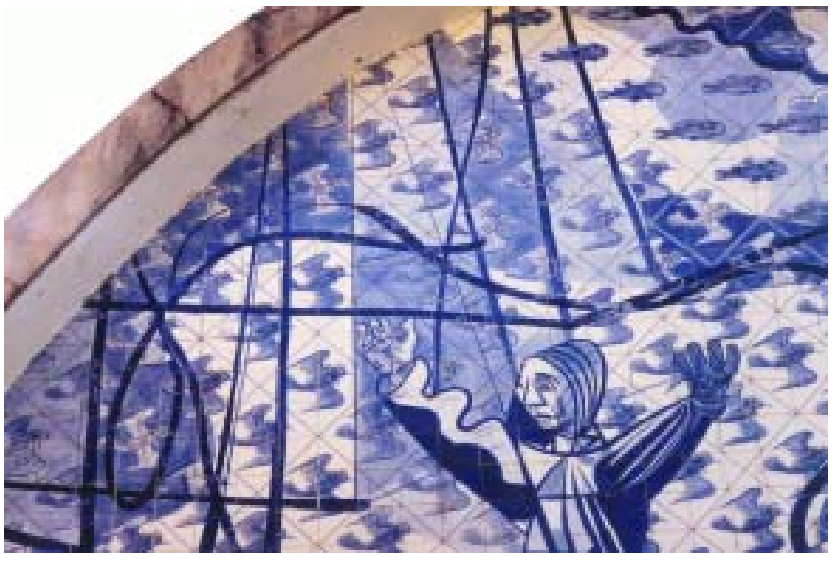

59 

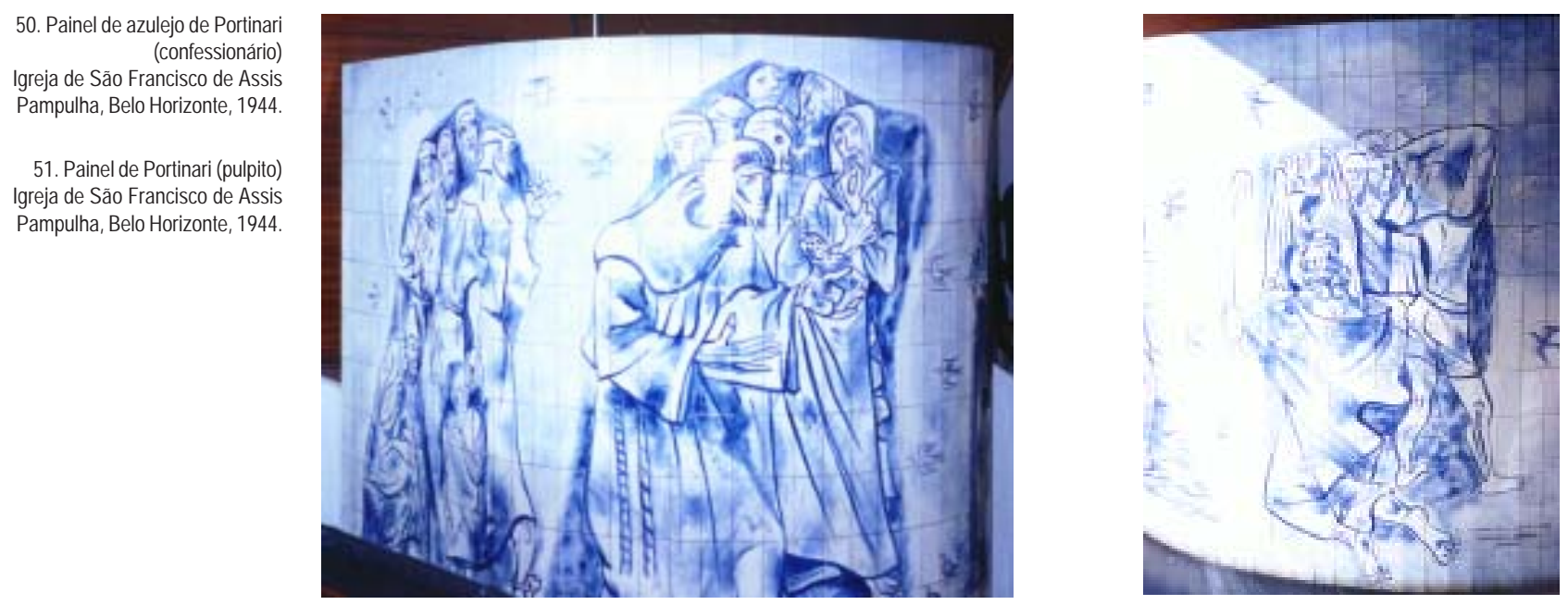

Associação Civil Clube, de Juiz de Fora, projeto de Francisco Bolonha, em 1956, que teria sido, provavelmente, a última obra mural de Portinari.

Oscar Niemeyer, como um dos principais renovadores da arquitetura brasileira, participou de todas as fases do projeto do MES e foi um dos arquitetos que solicitou com freqüência a colaboração de artistas em suas obras. Lemos (1984) nos informa que, para Oscar Niemeyer, 0 azulejo não deve ser encarado como material obrigatório ou como marca característica da arquitetura moderna brasileira, como se fosse uma "obrigação modernista". Seu uso justifica-se

52. Painel de Portinari Ginázio de Esportes do Conjunto Residencial do Pedregulho, Rio de Janeiro, 1951

Fonte: MORAIS, 1988, p.74.

53. e 54. Portinari, detalhe (meninos pulando carnica) Ginázio de Esportes do Conjunto Residencial do Pedregulho, Rio de Janeiro, 1951

Fonte: MORAIS, 1988, p.74 apenas como material resistente às intempéries.

Em Pampulha, tanto na capela franciscana como nos outros edifícios projetados por Niemeyer (a casa de Baile, o Cassino e o late Clube com os azulejos desenhados por Paulo Werneck), esse material está presente como fator unificador que confere unidade plástico-visual às superfícies. Niemeyer é o arquiteto mais lembrado quanto ao tema síntese das artes. Desde
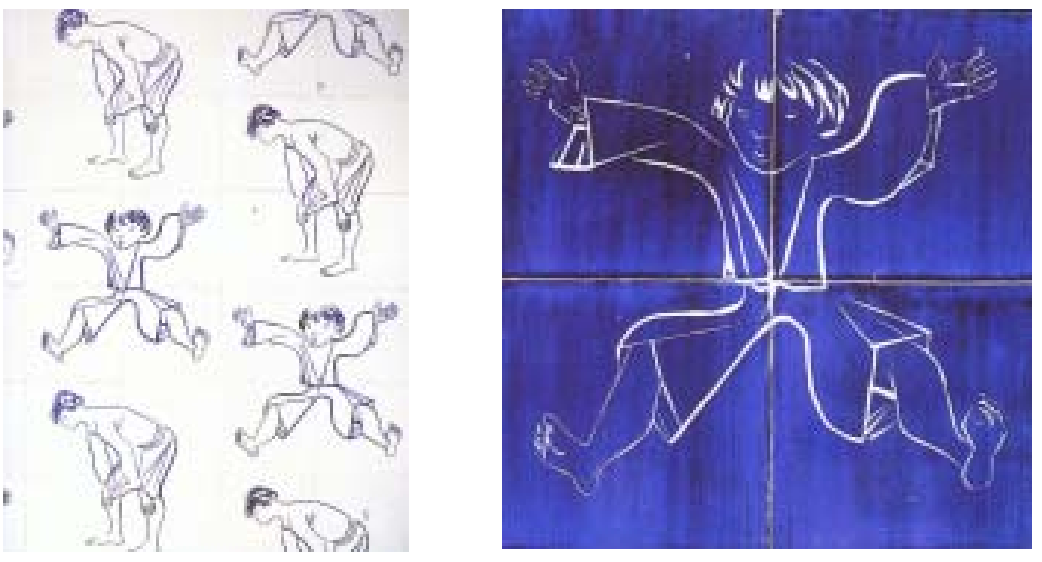

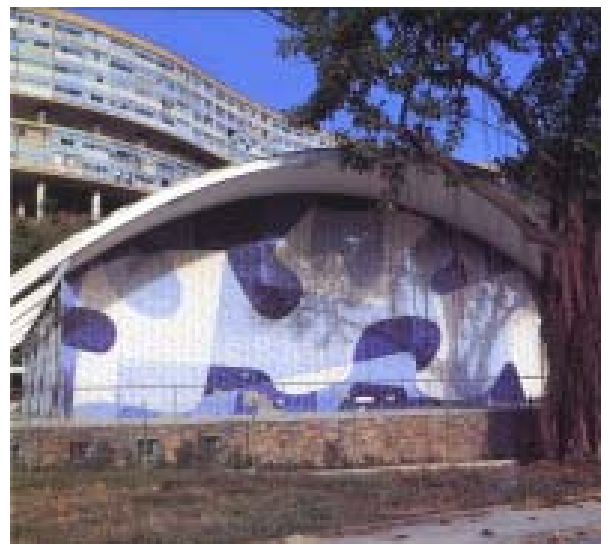



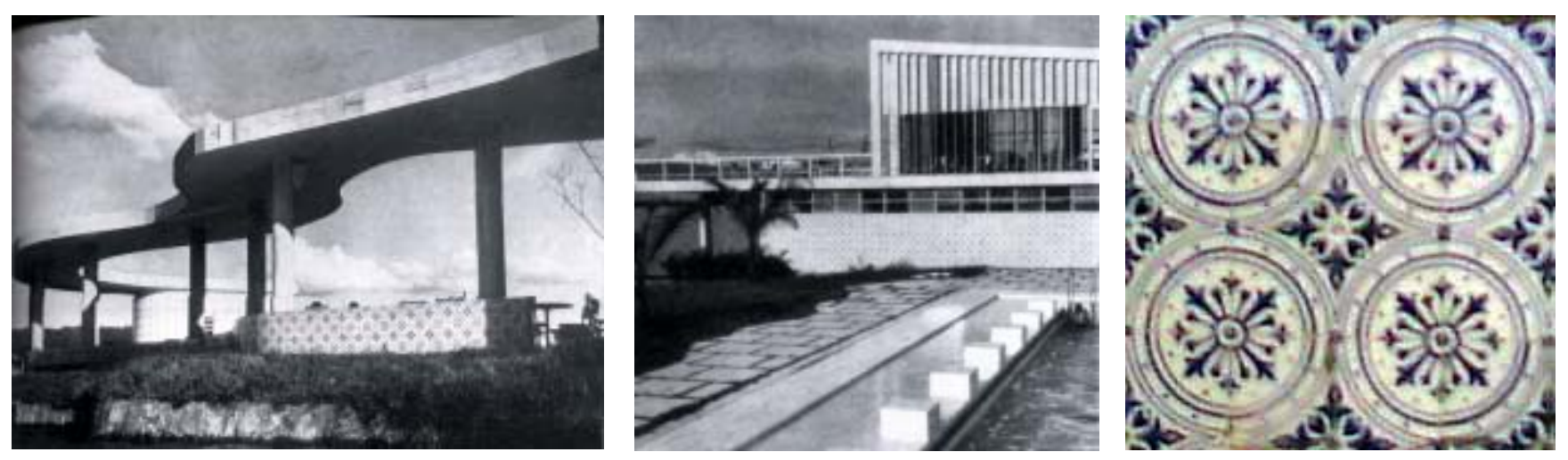

os seus primeiros trabalhos, existe a presença coerente e contínua desta idéia. Recorre ao uso de painéis de azulejos em seus projetos desde o prédio do MES e de Pampulha. De acordo com Melo (2003), Niemeyer já define a localização da obra de arte na concepção do projeto. Ainda no croqui ou num desenho avançado é definido o tema da obra, demonstrando, desta forma, que durante o projeto de criação o arquiteto vai identificando como e quem vai executar a obra de arte. Em Brasília, em várias obras, ele trabalhou em parceria com artistas plásticos, entre eles Athos Bulcão, que preencheu a cidade com seus painéis de azulejos, como trataremos adiante.

Em 1967, Niemeyer projetou o Edifício Castelo Branco - construído em Curitiba somente entre 1974 e 1976 - para funcionar como o Instituto de Educação do Paraná; no entanto, foi ocupado por órgãos públicos estaduais. No térreo do edifício, 0 arquiteto criou dois painéis de azulejos na cor amarela com fundo branco. São grafismos em forma de espiral, inseridos em quatro azulejos, compondo um jogo de positivo e negativo. Conforme a legenda do painel, ele foi executado em 2002 por Maria Helena Saporiti e Elvo Benito Demo.

Vinte e sete anos depois, em 2002, Niemeyer, com a colaboração do escritório Brasil Arquitetura, reforma e conclui o Novo Museu, projeto unindo os dois edifícios - 0 antigo Castelo Branco e o novo, cujo formato lembra um olho gigante. Neste novo edifício, Niemeyer revestiu, com azulejos amarelos-vivo, o prisma retangular (estrutura central) que suporta a parte superior em forma de olho. As paredes maiores desse prisma receberam enormes grafismos pretos que lembram folhagens e, numa das paredes menores de sua lateral, aparece um grafismo com a silhueta de uma mulata.

Depois de Portinari, vários outros artistas brasileiros como Burle Marx, Djanira, Poty, Caribe, Udo Knof, Antônio Maluf e Athos Bulcão, entre outros, trabalharam no campo da azulejaria integrada à arquitetura Burle Marx, como criador múltiplo (pintor, desenhista, gravador, tapeceiro, 

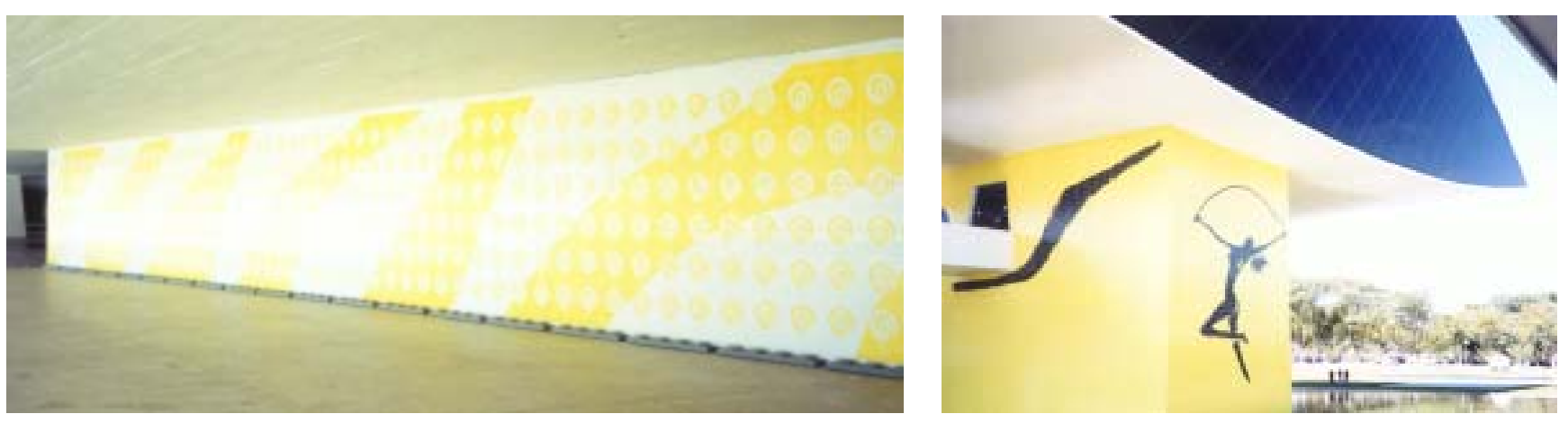

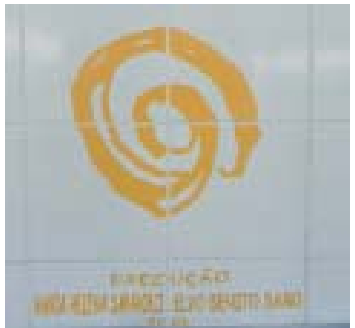

58. Painel de Niemeyer no Ed. Castelo Branco, Curitiba, 2002.

59. Painel de Niemeyer no Novo Museu, Curitiba, 2002.

60. Detalhe da legenda do painel de Niemeyer no Ed. Castelo Branco, Curitiba, 2002.

muralista, designer e paisagista) em qualquer trabalho adotava os mesmos princípios de composição. Em relação aos seus murais azulejados foi o artista que mais se aproximou de Portinari, talvez, por ter sido seu aluno, com criações pós-cubistas inseridas nas características do Modernismo dos anos 40 e 50 (MORAIS, 1988). Em 1950, criou um painel de azulejos para a parede lateral do Clube de Regatas Vasco da Gama, na Lagoa Rodrigo de Freitas. Trata-se de composição em tons azul e branco, com motivos aquáticos como peixes e moluscos. O tema se explica não apenas pela localização geográfica, como também, pela atividade do clube.

Na Fundação Oswaldo Cruz, em Manguinhos, também no Rio de Janeiro, ele criou dois painéis em 1953: um, é abstrato e recobre a fachada do prédio da Associação dos Funcionários, outro recobre a parede de um dos pavilhões do Instituto Oswaldo Cruz, novamente concebido em tonalidades azuis e brancas, com figuras marinhas - algas, lulas e águas-vivas. Há forte presença de linhas, planos sinuosos e ângulos agudos os quais criam profundidade e the dão aparência monumental.

Outro arquiteto que trabalhou com azulejos em colaboração com artistas, após visitar Pampulha, foi Rino Levi, tendo Burle Marx como um dos seus colaboradores ao longo dos anos. Para o Edifício Prudência, em 1948, em São Paulo, Burle Marx criou um painel de azulejos que tinha como objetivo "dinamitar" os volumes "incômodos" que tocam o solo, como nos painéis do MES. As paredes curvas do hall de circulação foram recobertas com painéis nos quais a composição foi baseada na repetição de dois módulos de formas sinuosas.

Rino Levi e sua equipe realizaram um exemplo de síntese das artes no projeto da residência de Olívio Gomes, em São José dos Campos, atual Parque da Cidade "Roberto Burle Marx". Para esta residência, Burle Marx criou, além do paisagismo, dois painéis. Como sua sugestão, foi criada uma parede para suportar o painel principal que se localizava no centro 

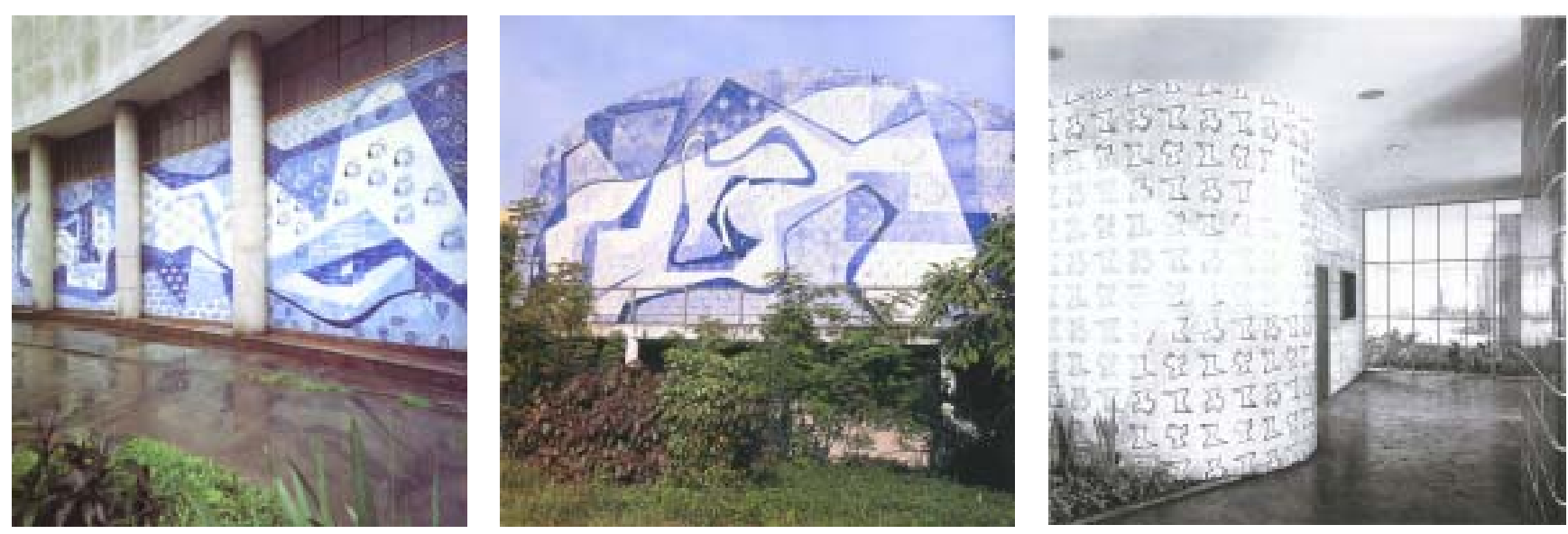

irradiador das linhas dominantes do jardim. O vermelho mais vibrante que as cores da casa destaca o painel do conjunto. O segundo painel está numa parede ao lado da entrada principal, é tratado como "matéria arquitetônica" necessária para conferir privacidade aos quartos. O painel de azulejos tem predominância do azul que sugere transparência (ANELLI, 2001). O autor confirma, ainda, que a colaboração de Burle Marx na casa de Olívio Gomes não implicou em imposições do arquiteto nem se restringiu a limites decorativos; a intenção do artista era a integração do espaço, das formas e das cores para valorizar a arquitetura.

Colaborando ainda com Rino Levi, Burle Marx criou um painel de azulejos esmaltados para revestir a parede do galpão e posto de gasolina da Tecelagem Paraíba, em São José dos Campos. No painel predominam formas lineares que, discretamente, remetem às formas das bombas e mangueiras do posto.

No espaço público localizado na Avenida Brasil com a Alameda Gabriel Monteiro da Silva, em São Paulo, anexo ao show-room da Incepa, o mesmo artista fez uso diferente do azulejo. Há neste painel forte concentração cromática, pelo emprego da cor e da ortogonalidade; concepção de vários planos numa composição geométrica pura, sem acrescentar nada aos materiais empregados: azulejos, faixas e revestimentos cerâmicos industrializados.

\section{Painéis do MES e a Osiarte}

No prédio do MES, por sugestão de Le Corbusier, as paredes de dois pequenos volumes que se tornaram incômodos por tocarem o solo entre os pilotis, foram revestidas com azulejos pintados, resultando no painel que renovava a tradição dos azulejos das casas portuguesas, tornando-se uma das principais características da arquitetura moderna brasileira. "A síntese

61. Burle Marx, painel de azulejos Clube de Regatas Vasco da Gama Rio de

Janeiro, 1950

Fonte: MORAIS, 1988, p.81.

62. Burle Marx, painel de azulejos Fundação Oswaldo Cruz, Manquinhos, Rio de

Janeiro, 1953.

Fonte: MORAIS, 1988, p.80.

63. Burle Marx, painel de azulejos Edifício Prudência, São Paulo, 1948.

Fonte: ANELLI, 2001, p.138 

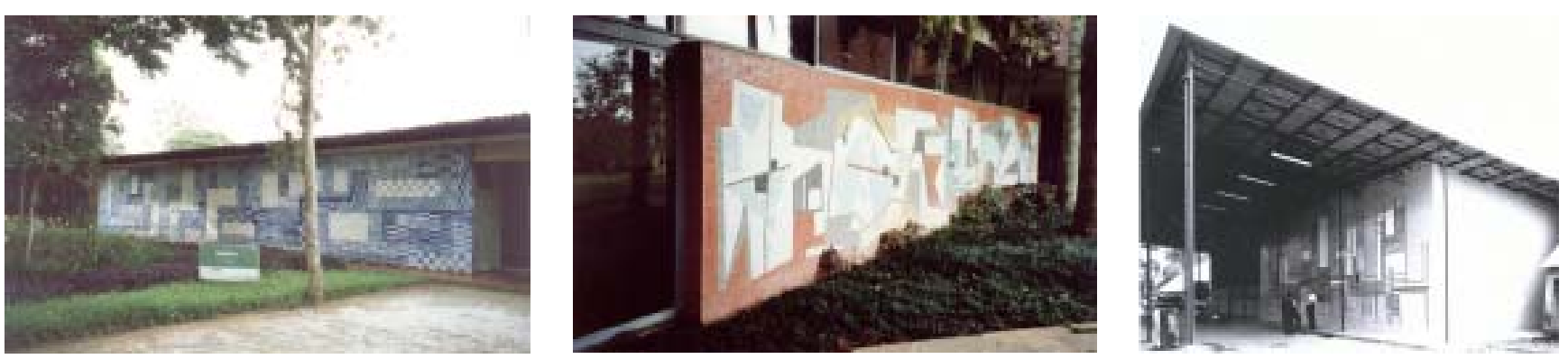

64. Burle Marx, painel de azulejos. Residência Olívio Gomes, São José dos Campos, 1950

Foto: Juliano Perreira.

65. Burle Marx, painel de mosaico vidrotil, Residência Olívio Gomes, São José dos Campos, 1950 Foto: JulianoPerreira.

66. Burle Marx, painel de cerâmica esmaltada.

Galpão de abastecimento da Tecelagem Paraíba, São José dos Campos, 1953. Fonte: ANELLI, 2001, p.145. conseguida é primorosa: o painel cumpre uma função arquitetônica, no sentido da construção de sua forma e, ao mesmo tempo, atualiza uma técnica tradicional local, conferindo uma especificidade brasileira a uma arquitetura internacional" (ANELLI, 2001, p.138).

Lúcio Costa explica as intenções na utilização dos painéis de azulejos, quando se defende das críticas de Max Bill, em 1953, que considerou os dois painéis do MES prejudiciais e inúteis.

"Ora, o revestimento de azulejos no pavimento térreo e o sentido fluido adotado na composição dos grandes painéis têm a função muito clara de amortecer a densidade das paredes a fim de tirar-Ihes qualquer impressão de suporte, pois o bloco superior não se apóia nelas, mas nas colunas. Sendo o azulejo um dos elementos tradicionais da arquitetura portuguesa, que era a nossa, pareceu-nos oportuno renovar-Ihe a aplicação" (COSTA 1995, p.202).

A retomada do azulejo é contemporânea ao esforço do modernismo brasileiro em atualizar e redescobrir nossas raízes culturais, uma renovação dentro da tradição (MORAIS, 1988).

Alcântara (2001) faz interessante comparação entre as casas portuguesas e partes dos painéis do MES, onde a composição bem moderna abriga elementos típicos da azulejaria portuguesa. Destaca a presença da malha, abrigando uma figura em seu interior como acontecia com os azulejos de tapete, do século XVIII. Destaca também o efeito da variação das escalas, desde os azulejos enxadrezados, onde ela se torna menor nos desenhos da parte mais elevada da parede. Nos azulejos do MES, essa variação tem o propósito de enfatizar algumas áreas em relação a outras ou aparece, até mesmo, como definição dos limites, presentes nos azulejos do século XVII, embora interpretados com maior liberdade.

Costa (1986), porém, explica que:

"Nos anos trinta a retomada dessa tradição perdida se deveu a uma sugestão de Le Corbusier, não para a sede do então Ministério da Educação e Saúde, mas para uma série 


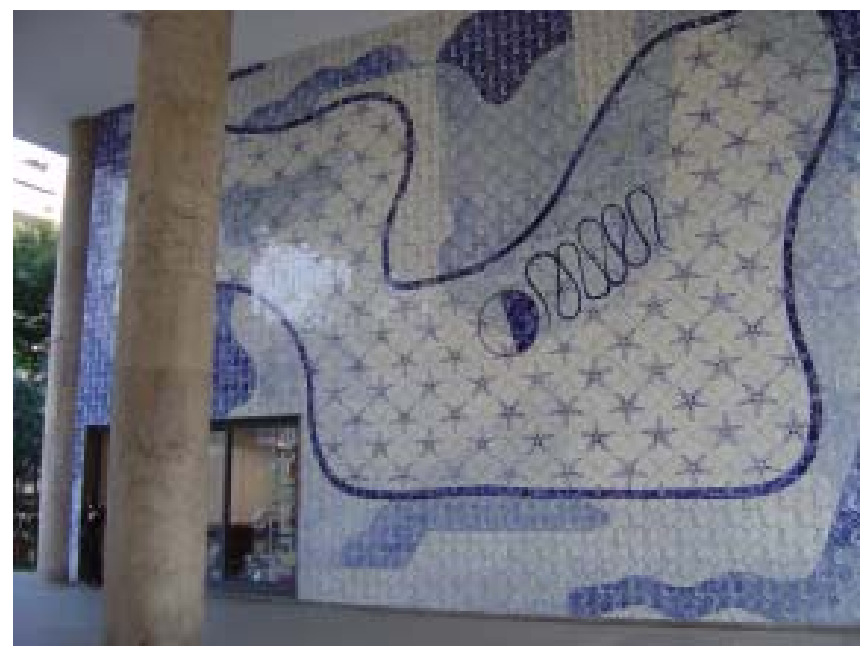

de escolas técnicas que o Ministro Capanema, em 1936, pretendia construir. Só alguns anos depois, quando surgiu a obra do Ministério e o problema do revestimento das paredes térreas não estruturais, ocorreu-me a idéia de aproveitar aquela sugestão feita ao Ministro na minha presença".

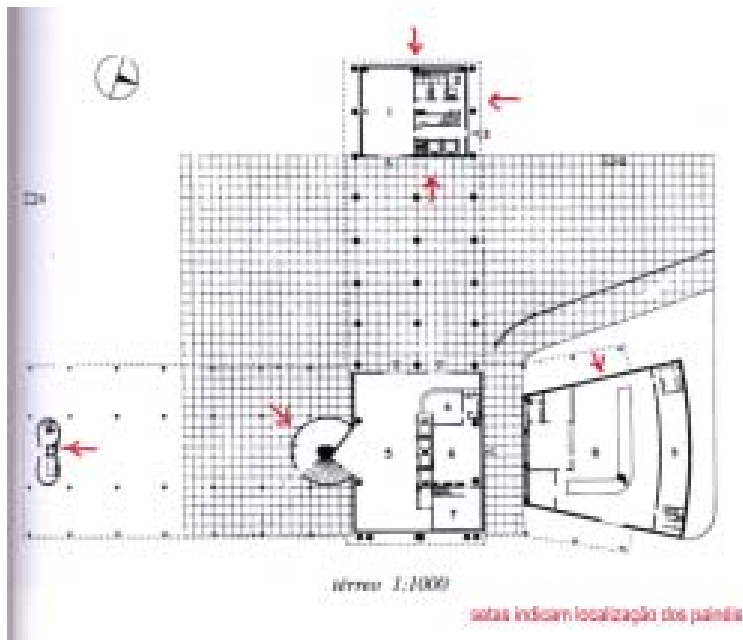

67. Portinari, painel de azulejos Prédio do MEC, Rio de Janeiro, 1945.

68. Planta térreo Edifício do Ministério da Educação e Saúde. Rio de Janeiro, 1943.

Fonte: Mindlim, 2000, p.221.

No prédio do MES foram então implantados painéis de azulejos em cinco pontos diferentes. É preciso destacar que três painéis são de autoria de Paulo Rossi Osir e dois, localizados no bloco lateral que dá para a Avenida Graça Aranha, são desenhos de Portinari, embora algumas publicações atribuam a autoria de todos os painéis apenas a Portinari.

Nos três painéis de Osir aparecem figuras marinhas isoladas, tais como cavalo-marinho, concha, peixe, estrela-do-mar, caracol, tritão, delfim, caravela, caranguejo e coral, dispostas em diagonal na composição. No painel de superfície ondulada vemos, em cima de uma das portas, uma composição que lembra cartelas barrocas, são duas manchas superpostas, contendo peixes, caramujos, caracóis, sereias e linhas, sugerindo algas marinhas. "O resultado em todos eles é visualmente muito atraente, sobretudo pela nitidez do desenho de cada figura e pelos arranjos resultantes, com distribuição frontal dos elementos figurativos, como se estivéssemos diante de um aquário" (MORAIS, 1988, p. 32).

Nos painéis de Portinari, os azulejos cumprem também função decorativa e ajudam a criar um clima agradável para os transeuntes que circulam entre os pilotis de dez metros de altura, dando a sensação de estar numa praça. Suas composições, assim como as de Osir, são nas cores azul - em várias tonalidades - e branco, com figuras de animais marinhos. Em um dos painéis, uma linha sinuosa, longa e viril envolve toda a composição, sugerindo a forma de uma 


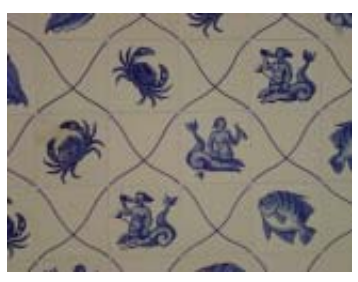

69. Paulo Rossi Osir, painel de azulejos (volume sinuoso) Prédio do MEC, Rio de Janeiro,

1945.

70. Paulo Rossi Osir, detalhe do painel de azulejos com malha em diagonais.

Prédio do MEC, Rio de Janeiro,

1945.

71. Paulo Rossi Osir, painel de azulejos. Prédio do MEC, Rio de Janeiro,
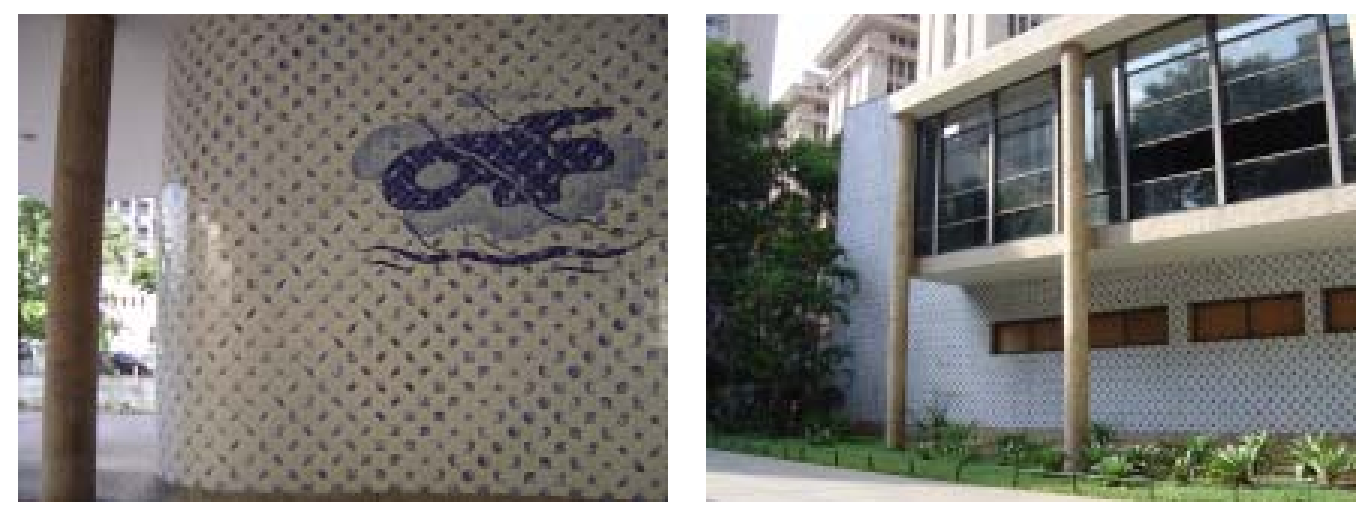

ameba. A escolha do tema adotado pelos dois artistas se explica, certamente, pela proximidade do edifício com o mar, a qual na época da execução do projeto era ainda maior (MORAIS, 1988).

Para atender a encomenda da execução dos painéis do MES, o pintor Paulo Rossi Osir criou a Osiarte, em 1940, em São Paulo. O investimento feito na execução dos painéis exigiu grande esforço para obtenção das tonalidades de azul desejadas e também muita paciência para enfrentar a habitual lentidão da burocracia ministerial. Mas o esforço rendeu-lhe bons resultados; além dos painéis do MES, a Osiarte executou vários outros para artistas como Portinari, na igreja de São Francisco de Assis, na Pampulha e no Conjunto residencial do Pedregulho; para Burle Marx, no Instituto Oswaldo Cruz em Manguinhos e no Clube de Regatas Vasco da Gama, na Lagoa; para Anísio Medeiros, em Pedregulho e Cataguases e para Poty, em Curitiba.

Concluídas as obras para o MES, Rossi Osir procurou ampliar a aplicabilidade dos azulejos, dando início a outro tipo de produção azulejar, representada por composições próprias numa linguagem de pinturas. Eram pequenas composições decorativas, tanto em azulejos únicos de padrão avulso, como em várias unidades. Apareciam sempre cenas brasileiras: cenas de trabalho, momentos solenes das festas religiosas ou folguedos tradicionais. Elas se destinavam não apenas como revestimento de paredes, como também ao uso em decorações de ambientes internos, produção de móveis, lareiras, banheiros, piscinas e fontes.

Paulo Rossi Osir, que foi o diretor geral da Osiarte, era encarregado de remunerar 0 trabalho dos artistas, contactar interessados, promover e comercializar os produtos. Criou também a linha temática folclórica e popular, visando à exportação dos azulejos, especialmente para os Estados Unidos. Exposições dos produtos eram feitas regularmente como estratégia de difusão. O mercado americano chegou a se interessar pelo trabalho, adquirindo, em 1942, uma obra da Osiarte para compor o acervo do Museu de Arte Moderna de Nova York. 

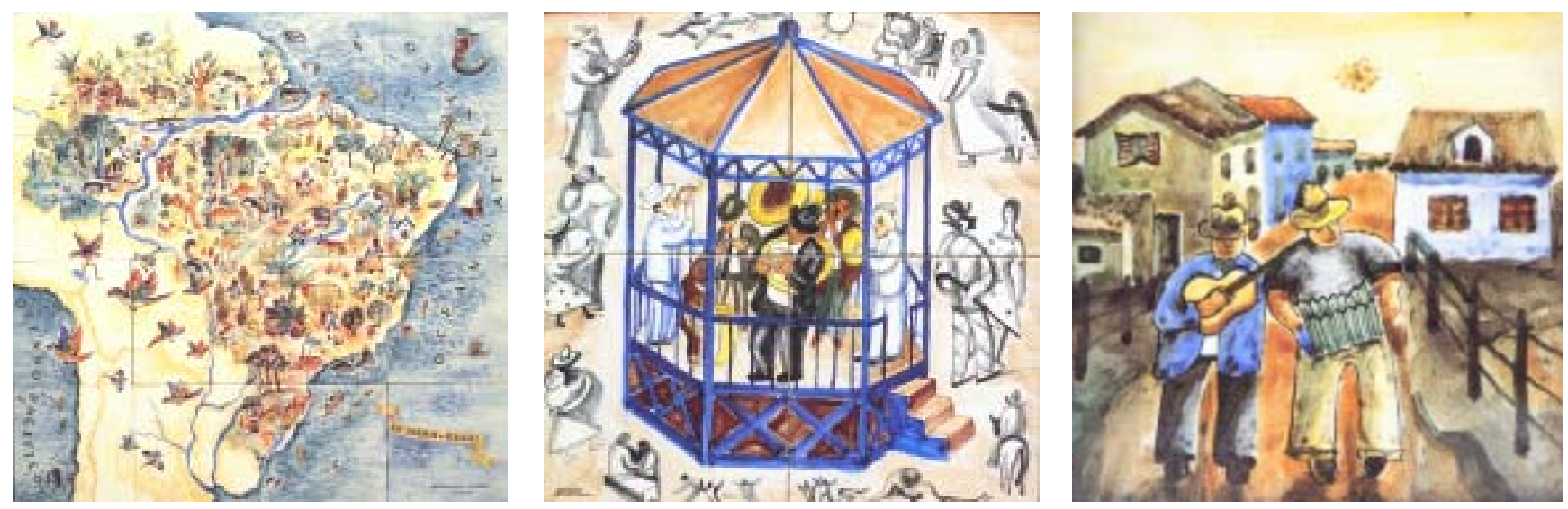

A Empresa atuou nas décadas de 40 e 50, a amizade de Portinari e Osir foi fator decisivo para o sucesso do empreendimento. Vários foram os artistas que trabalharam na Osiarte, dentre eles, Zanini, Volpi, Hilde Weber, Giuliana Giorgi, Gerda Brentani e Maria Wrochnik. O trabalho da Osiarte foi uma iniciativa inovadora. Primeiramente, pelo esforço de integração, com os artistas trabalhando em conjunto numa mesma composição, adotando assinatura coletiva, numa forma de trabalho menos competitiva; aqueles que permaneceram por mais tempo, acabaram direcionando seu estilo, interesse, expressão e relação com o tema, como no caso de Hilde Weber, que realizou a temática dos mapas do Brasil (LOURENÇO, 1985).

O trabalho na oficina também integrava os iniciantes e experientes: convivendo no mesmo ambiente, repartiam o conhecimento do fazer. Porém, como nas oficinas medievais, mantinham uma hierarquia no tipo do trabalho. Destacava-se também a integração entre arte e indústria, tanto operacionalmente, uma vez que os azulejos eram produzidos e queimados nas Indústrias Reunidas Matarazzo, quanto no procedimento de concepção dos artistas que, ao criarem a composição, previam modificações (tonalidade e efeito) na execução realizada pelos operários. Lemos (1984), porém, informa que os azulejos da Osiarte teriam sido queimados na Indústria Ranzini, na Lapa. Como numa indústria, era estabelecido um circuito de ações integradas, onde as responsabilidades de cada etapa do processo eram divididas, desde o investimento ao lucro.

Vale lembrar a técnica usada pela Osiarte. Os desenhos geralmente eram feitos por Volpi e Zanini, com sugestões de Osir. O esboço era feito em papel de seda e os contornos perfurados com alfinete, num processo semelhante àqueles antigos já descritos. Os azulejos eram colocados em cima de um cavalete inclinado, em cuja base havia um encaixe para a primeira fila e as seguintes apoiavam-se nas de baixo. Após a pintura, os azulejos eram numerados nas costas e colocados em engradados para que não encostassem uns nos outros. Eram usados,

72.Hilde Weber, composição de 16 azulejos

Osiarte, São Paulo, década de 40

Fonte: MORAIS, 198, p.41.

73. Zanini e Volpi, composição com 4 azulejos

Osiarte, São Paulo, década de 40 Fonte: MORAIS, 1988, p.46

74. Volpi, azulejos avulsos Osiarte, São Paulo, década de 40 Fonte: MORAIS, 1988, p.47. 
além do azul, vários tons de verde, o amarelo, os terras, o roxo, os rosas e o preto. O vermelho não era muito usado, por exigir temperaturas mais baixas que os $1200^{\circ} \mathrm{C}$, normalmente usados nas queimas (TARASANTCHI, 1985).

A técnica de pintura era a do "baixo esmalte", isto é, a pintura era feita no biscoito, que por ser uma superfície porosa, absorve a tinta com rapidez e só depois recebia uma camada de esmalte transparente. Essa técnica exigia rapidez e domínio na pincelada, pois qualquer retoque era visível após a queima. O preparo dos esmaltes também exigia cuidado. Como eram preparados com água e cola, as cores opacas tornavam-se totalmente diferentes depois de queimadas, exigiam dosagem certa, pois quanto mais ralas tornavam-se mais suaves e mais vivas, quanto mais concentradas. $\mathrm{O}$ resultado da pintura lembra uma aquarela, mas a execução é bem mais difícil (TARASANTCHI, 1985).

Segundo Lourenço (1985), a extensão desse uso do azulejo proporcionada pela Osiarte, deu continuidade à tradição luso-brasileira, de utilizar esse material para enfeitar os edifícios. Não podemos ignorar a importância dessa produção que está ligada ao momento histórico vivido, colaborando para o desenvolvimento e difusão da linguagem plástica renovada e que representou uma ação diferenciada.

\section{Azulejos de Delfim Amorim}

Em 1951, o arquiteto Delfim Fernandes Amorim, português, veio para o Recife, onde começou a trabalhar com Acácio Gil Borsoi em seu escritório de arquitetura e nesta cidade, realizou o essencial de sua obra. Durante vinte anos projetou obras que marcaram a paisagem da cidade e também demonstrou suas idéias desenvolvidas na Faculdade de Arquitetura. Seus primeiros trabalhos no Recife foram influenciados, naturalmente, pelas "receitas" da arquitetura moderna européia, mas já adotando soluções brasileiras, como o emprego do cobogó, devido às condições diferentes de clima.

Um dos pontos mais relevantes da obra de Amorim para esta pesquisa é o processo como ele trabalhava o azulejo em seus projetos arquitetônicos. Analisando seus trabalhos, parecenos que ele partiu da estética, forma plástica do azulejo, para resolver um problema funcional. Com o clima quente e úmido do Recife, se faz necessário rápida alteração dos revestimentos externos, exigindo contínuas mãos de tinta para combater a ação do sol, da água e do mofo que recobre as paredes com manchas pretas, as quais nem o concreto consegue evitar. Como solução, 
ele recobriu com azulejos as paredes dos grandes imóveis antigos, processo caro, porém, que evitava maiores gastos com manutenção. "Deve-se a Amorim a retomada do gosto pelo azulejo, não pelo seu valor histórico, mas pelo seu valor prático na medida em que protege, em definitivo, as paredes que reveste e por suas potencialidades plásticas" (DELFIM, 1991, p.61).

Por razões próprias Amorim não gostava das linhas industriais de azulejos da época e por esse motivo teria criado desenhos exclusivos para algumas de suas obras. Em alguns casos, a produção era artesanal, os desenhos eram feitos com máscaras removíveis sobre azulejos brancos comuns, onde a tinta era então aplicada com pistola.

A hipótese que podemos chegar é que Amorim teria sido conquistado pela capacidade decorativa desse elemento tradicional da arquitetura, mais do que qualquer outro motivo. Em suas obras nem todas as paredes externas eram revestidas de azulejos, existia também a preocupação em desenhar os motivos específicos para cada caso. O azulejo era usado nas residências, em edifícios de maior porte, coexistindo com a pedra, o reboco, o concreto aparente, o tijolo à vista, tornando evidente a intenção da composição de elementos com diferentes texturas. Seus edifícios se destacam no espaço urbano, pela utilização de certos procedimentos sempre juntos, em maior ou menor escala, entre eles o uso do azulejo.

Ele idealizou uma série de azulejos que se diferenciaram quanto à época em que foram criados e quanto a sua aplicação. No Edifício Acaiaca, onde demonstra feliz união, até hoje se nota coerência do edifício com a sua aplicação. Os azulejos foram empregados para revestir as empenas e formar molduras horizontais na fachada leste. Em outros edifícios, revestem apenas os volumes correspondentes aos guarda-roupas que sacam em relação ao paramento das fachadas, como no Edifício Barão do Rio Branco. Outras vezes, comparecem como molduras de duas fachadas inteiras, compostas de elementos pré-fabricados de concreto armado, como no Edifício Independência. Finalmente, no Edifício Santa Rita, os azulejos funcionam como fundo onde se aplicaram caixas de concreto armado para instalação de aparelhos de ar condicionado, de maneira pioneira (DELFIM, 1991).

Segundo Amorim (1989), no final dos anos 50, o trabalho de seu pai já se encontrava bem regionalizado, com o azulejo assumindo papel fundamental. Nesta época, os arquitetos cariocas desenvolviam azulejos em painéis concebidos como obras de arte, enquanto Delfim Amorim trabalhava com a azulejaria de tapetes, uso que foi bastante comum no século XIX, no litoral brasileiro. Nos azulejos do tipo tapete o princípio de produção em série vai de encontro à 
75. Delfim Amorim, fachada de azulejos. Edifício Barão do Rio Branco, Recife,

1969.

76. Delfim Amorim, fachada de azulejos. Edifício Santa Rita, Recife, 1962

77. Delfim Amorim, fachada de azulejos.

Edifício Acaiaca, Recife, 1957

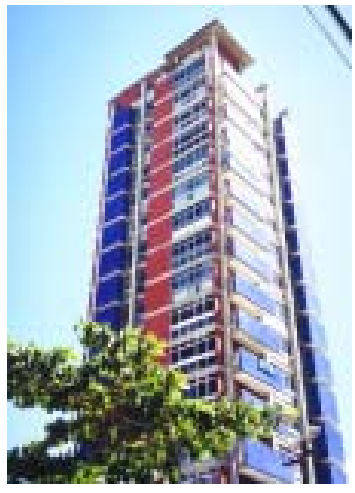

exclusividade do painel artístico. Delfim Amorim, porém, se coloca em posição intermediária ao desenvolver azulejos exclusivos para cada obra, integrando-os ao objeto arquitetônico.

Bruand (2002) lembra que esse procedimento não foi utilizado apenas por Amorim. Os arquitetos cariocas também o empregaram, desde a construção do o Ministério da Educação e Saúde, por sugestão de Le Corbusier, no entanto, dentre eles Niemeyer e Reidy conceberam painéis de azulejos em algumas paredes, como grandes afrescos, sem função estrutural. Amorim, por sua vez, utilizava os azulejos como simples revestimento em qualquer parte da obra, com um único motivo e eram produzidos em série. O conjunto não tinha o objetivo de uma obra de arte integrada à arquitetura, mas acrescentava-Ihe um complemento decorativo que não teria sentido fora dela. Seria então, uma retomada do princípio das fachadas de azulejo do século XIX no Recife.

"Segundo o arquiteto, ao conceber os motivos dos azulejos, imaginava três pontos de percepção. O primeiro, a longa distância, não permitia a identificação do azulejo, mas sim a soma cromática das cores componentes. Um segundo ponto, de média distância, possibilitava a visualização do tapete formado pela aplicação do motivo padrão, que só será identificado num terceiro momento, próximo à superfície" (AMORIM, 1989, p.96).

Usando essa lógica, os azulejos criados para residências e edifícios de pequeno porte possuem um desenho mais delicado por causa da escala do edifício. Pois os últimos momentos, que correspondem a média distância e perto da superfície, se tornam quase um só, enquanto
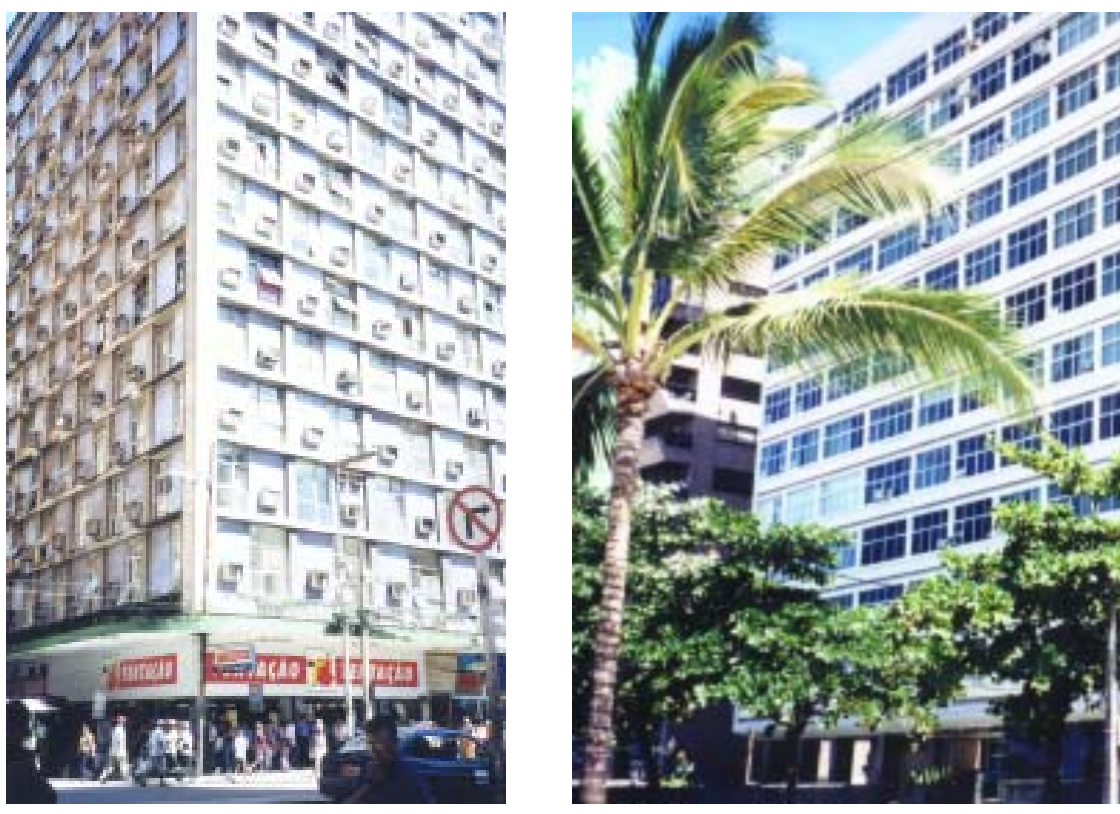

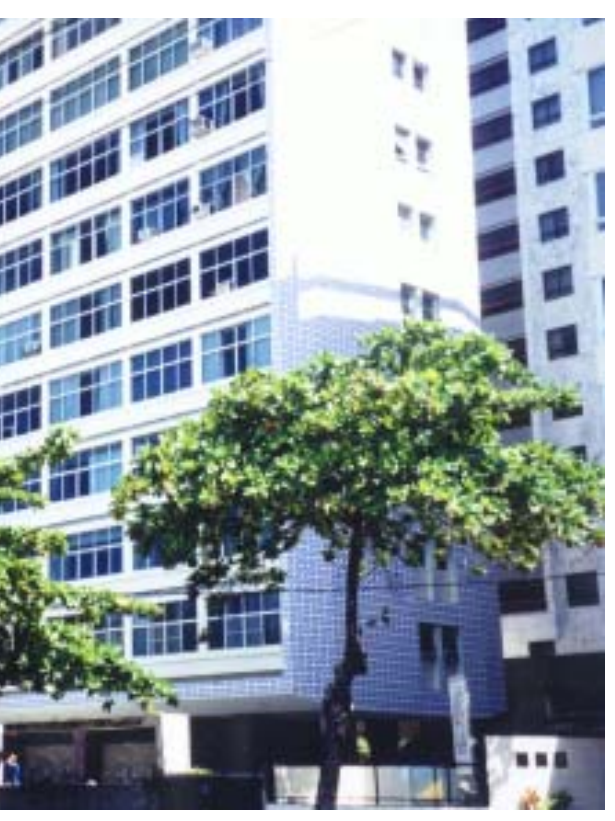


que o primeiro momento, a longa distância, muitas vezes não existe. Como por exemplo, o azulejo desenhado para a residência Amaro Dias, em 1958. A própria peça compõe o desenho e sua aplicação nas diferentes fases cria o tapete. Já no azulejo criado para o Edifício Acaiaca, também em 1958, o desenho é um jogo de planos superpostos que enriquecem os diferentes momentos de percepção. O motivo básico só é formado com a aplicação de doze peças, no mínimo, a fim de ampliar o horizonte de leitura.

Com a experiência adquirida com os projetos de revestimento de grandes superfícies, Amorim vai simplificando o desenho, reduzindo o número de planos e cores, e usando elementos geométricos puros. Como no azulejo criado para o Edifício Santa Rita, em 1964, onde o fundo branco é substituído pelo azul escuro. Um outro exemplo dessa simplificação é o azulejo do edifício Barão do Rio Branco, de 1968, onde o motivo básico é conseguido com a aplicação de azulejos desenhados (com apenas um retângulo branco na vertical) e outros sem desenho.

Bruand (2002, p.148) conclui que os elementos que Amorim tomava emprestado do passado não eram decorrentes de opinião preconcebida nem da intenção de criar um estilo, mas foram guiados por considerações práticas e pela vontade de dar solução adequada a cada caso. "Os elementos essenciais tomados de empréstimo à tradição luso-brasileira são quatro: 1) os telhados de telha-canal com grandes beirais; 2) as venezianas e muxarabis; 3) as varandas e galerias de circulação externas; 4) os revestimentos de azulejos".

Santos (2003), artesão português que trabalhou com Amorim, pintando alguns azulejos, conta que sentia que Amorim queria deixar sua marca nas obras que realizava. Não gostava de cópias, por isso, criava ele mesmo o padrão dos azulejos que utilizava nas obras, levava -lhe 0 desenho pronto no papel, com as cores definidas. Domingues, então, reproduzia o desenho no papel vegetal, separando as cores para fazer os moldes dos desenhos que eram recortados em folhas de zinco, com serra usada na ourivesaria. Para cada cor, era feito um molde correspondente e a tinta era aplicada com pistola, num processo bem artesanal. Domingues, como bom artesão apaixonado pelo ofício, prefere os azulejos pintados dessa maneira. Ele diz que, com a prática, consegue-se controlar bem a cor nos moldes, utilizando-se a pistola tem-se o efeito de sombreamento, que existia nos azulejos antigos e que com uma única cor, atingem-se duas ou mais tonalidades diferentes, variando apenas a intensidade da tinta que sai da pistola. 


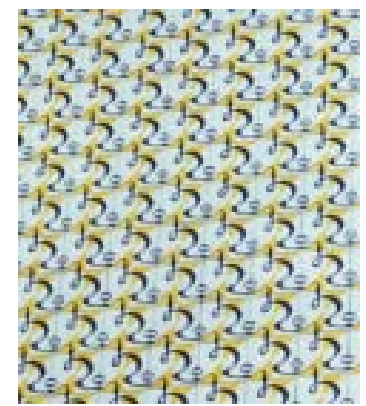

78. Padrão de azulejo de Delfim Amorim criado para Residência Joaci Soares e copiado em outros projetos.
Embora a pintura com serigrafia resulte em desenho duro, com traços chapados, sem a leveza e beleza plástica da pintura artesanal, com 0 advento das máquinas serigráficas, as indústrias passaram a utilizá-las e as oficinas e ateliês de pintura artesanais foram desaparecendo.

Santos (2003) conta também que a cor azul que prevalece nos azulejos de Amorim teria sido em razão da tradição dos azulejos portugueses nos quais esta cor predominava. $\mathrm{O}$ azul era um corante natural, extraído do cobalto, portanto, mais fácil de se obter em épocas passadas. Amorim encantou-se com o trabalho do Domingues logo na primeira encomenda, os azulejos do edifício Acaiaca. Depois, vieram os azulejos da residência Joaci Soares e do Edifício Araguaia.

Após a utilização dos azulejos em suas obras, Amorim não fazia questão de exclusividade, liberando os moldes para serem usados por quem os quisesse, pois sabia que a cópia desse tipo de produto era muito fácil e comum. Prova disso são os azulejos criados para a residência Joaci Soares que foram usados com outras cores em outras obras, como na fachada do Edifício Julino, na Rua Epaminondas de Melo, 109, no Derby e na fachada de residência na Rua Padre Anchieta, na Torre, nas cores preta e rosa. 


\section{azulejos de athos bulcão}

\section{O artista Athos Bulcão}

Ao debruçar sobre a obra de Athos Bulcão, o que primeiro nos chamou atenção foi a riqueza, a qualidade e a especificidade do seu trabalho com painéis de azulejos. Depois, com 0 conhecimento do seu caráter e personalidade simples, veio a certeza de que o caminho a estudar era mesmo Athos Bulcão.

Infelizmente, não foi possível entrevistá-lo pessoalmente; quando estive em Brasília, para realização da pesquisa; ele estava em tratamento de saúde, mudando a medicação e seu secretário não julgou conveniente a entrevista. Contudo, os textos, outros entrevistados, as visitas, os contatos, enfim, o material obtido, foi suficiente para a realização do estudo a que nos propusemos.

Athos Bulcão nasceu no bairro do Catete, no Rio de Janeiro, em 1918, no seio de uma família com status social. Filho caçula e tardio era onze anos mais jovem que seu irmão. Suas duas irmãs substituíram a mãe que faleceu quando Athos tinha menos de cinco anos de idade. Foi criado como "burguesinho rico". Suas irmãs sempre o levavam a teatros, óperas, exposições, sua vida cultural era intensa, sempre rodeado de adultos. "Eu não jogava bola nem soltava pipa, gostava mesmo era de coisa de gente grande" (ATHOS..., 2004). Desde pequeno gostava de desenhar, mas sem despertar a atenção da família.

Aos 18 anos entrou para o curso de medicina na Faculdade Fluminense de Medicina para satisfazer a família, mas abandonou-o no terceiro ano, influenciado pela leitura de Cartas a um Jovem Poeta, de Rainer Maria Rilke. "Era como se Rilke falasse diretamente para ele: "procure entrar dentro de você, reflita bastante se a arte é imprescindível, se você não pode viver sem a arte. Não contrarie sua natureza de poeta'. Ele decidiu não contrariar sua natureza de poeta e jogou para o espaço o curso de Medicina, sem saber direito qual seria seu destino" (FRANCISCO, 2001, p.325). Nessa época, sua família perdeu tudo o que possuía, em conseqüência de má sociedade que seu pai fizera com outros. Athos começou, então, a desenhar retratos para ganhar algum dinheiro e ajudar no sustento da casa. Iniciou-se na pintura, passou a conviver com 
jornalistas, escritores, poetas, artistas, músicos, arquitetos, grupos intelectuais cariocas, além de fazer amizades com outros pintores.

Em 1941, foi selecionado para o Salão Nacional de Belas Artes, Divisão Moderna, obtendo Medalha de Prata em desenho e pintura. Com suas amizades no meio artístico, começou a freqüentar o ateliê e a casa de Burle Marx, que funcionava como ponto de encontro de intelectuais e artistas modernistas. Foi lá que, em 1943, Oscar Niemeyer se encantou com um desenho de Athos e convidou-o para transformar o desenho em azulejo para o painel do Teatro Municipal de Belo Horizonte, não foi realizado, mas ali começou uma grande amizade e parceria em trabalhos que integravam arte e arquitetura.

Em 1942, Athos começou a freqüentar o atelier de Maria Helena Vieira da Silva e de Arpad Szènes, exilados aqui no Brasil durante a guerra. A influência da obra de Vieira da Silva (Escola de Paris) revelou a Athos a existência de uma estética diversa da nossa.

A convite de Cândido Portinari, em 1945, trabalhou como assistente na execução do painel de São Francisco de Assis, na Igreja da Pampulha, em Belo Horizonte. Após esse trabalho, estagiou no ateliê do pintor, no Rio de Janeiro, onde aprendeu muitas lições importantes sobre cor e desenho. Apesar da personalidade forte de Portinari, Athos não se deixou influenciar. Sua arte é bem diferente da do Mestre. Além de Portinari, Athos conviveu, também, com Di Cavalcanti, com o qual gostava de conversar, mas não sobre arte.

"Athos assimilou essas lições para sempre. Antes de pintar, planeja as cores que vai usar. Raramente muda a cor do trabalho. O resultado final é um mistério. Mas insiste na convicção de que o artista tem de saber o que quer fazer. Ele não acredita na noção romântica de inspiração que baixa e soluciona todos os problemas estéticos. Acredita em muito trabalho" (FRANCISCO, 2001, p.328).

De 1948 a 1950, Athos estudou na École de Beaux-Arts na França, com bolsa de estudo conseguida através de recomendações de Portinari, Alceu Amoroso Lima e Dom Marcos Barbosa. Foi um período muito produtivo. Por instinto e intuição, passou três meses observando a arte clássica e a arte moderna no Louvre, estabelecendo conexão entre ambas. Percebeu que 0 moderno já existia em muitas obras clássicas.

Em 1951, Athos visitou a I Bienal Internacional de São Paulo, a qual Ihe teria causado grande impacto. No ano seguinte foi admitido como funcionário do Ministério da Educação e 
Cultura, no Serviço de Documentação, onde desenhou capas e ilustrações para revistas, catálogos e livros. É nesse período que começou também a realizar suas primeiras fotomontagens.

Seis anos mais tarde, foi morar em Brasília, a convite de Oscar Niemeyer, para realizar uma série de colaborações em projetos de integração arte/arquitetura. Foi requisitado do MEC para a Companhia Urbanizadora da Nova Capital - NOVACAP. Foram mais de duzentas obras marcadas pelo toque de elegância, leveza e vibração de cores. Athos levou para Brasília um pouco do que havia de melhor no modernismo brasileiro (ATHOS..., 2004). O ritmo de trabalho em Brasília era outro, bem intenso, as obras eram realizadas sem muito tempo para projeto e execução. Dentre outras, destacamos o relevo do Teatro Nacional e painéis de azulejos na Igrejinha de Nossa Senhora de Fátima, da 308- Sul, nos Palácios do Itamaraty e da Alvorada, no Brasília Palace, no Congresso Nacional, no Panteão da Pátria, e no Palácio Jaburu.

De 1962 a 1965, foi professor no Instituto Central de Artes da Universidade de Brasília (UnB), convidado por Darcy Ribeiro. Em protesto contra o regime militar, deixou a UnB em 1965, com mais de duzentos professores. Regressando a UnB, pela lei da Anistia, voltou a lecionar de 1988 a 1990 quando recebeu aposentadoria compulsória.

Desde 1962, firmou outra grande parceria para obras de arte/arquitetura com o arquiteto João Filgueiras Lima, o Lelé. Com ele, criou vários relevos, divisórias e painéis no Edifício da Disbrave, em Brasília, no Hospital de Taguatinga (DF), nas secretarias do Tribunal de Contas da União, em algumas cidades brasileiras e nos hospitais da Rede Sarah. Para Lelé, as intervenções de Athos não são apenas decorativas, interferem na sua concepção de arquitetura, o que 0 diferencia de muitos arquitetos, que acreditam que a arte só deve entrar no edifício depois de pronto (FRANCISCO, 2001).

79. e 80. Máscaras $60 \times 60 \mathrm{~cm}$. Relevo policromado. 1975 Fonte: ATHOS, 2001, p.308.

81. Capa da revista Módulo, $n^{\circ} 44$, dez/jan. 76/77.

82. Capa do livro Cidade e a roça de Rubem Braga.

Entre 1971 e 1972, Athos desenvolveu vários projetos na Europa e na África, a convite de Oscar Niemeyer, colaborando com obras de arte/arquitetura.
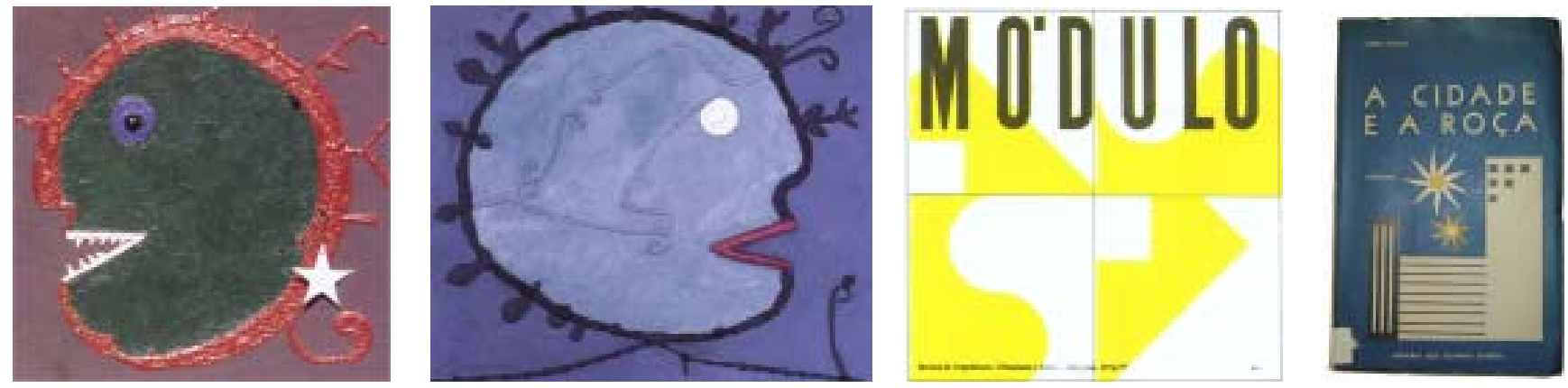


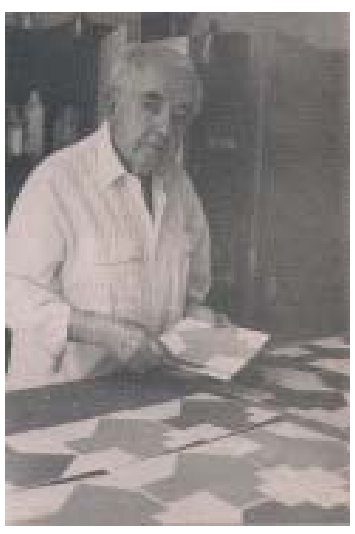

83. Athos Bulcão Fonte: Jornal de Brasília, 2/7/98.

${ }^{13}$ Eduardo Cabral foi um dos idealizadores e criadores da Fundação Athos Bulcão. No escritório de Eduardo vi algumas telas de Athos Bulcão, reproduções em serigrafias de alguns painéis de azulejos. Para as serigrafias foram criados títulos como Natividade (igrejinha Nossa Senhora de Fátima). Vi também projetos de Athos Bulcão de paramentos para a Catedral de Brasília (casula), em guache, mas não foram executados. Vi também um quadro de Cândida, cozinheira de Athos que também pinta. Na convivência com Athos Bulcão ela se interessou pela pintura e ele the ensinou a pintar. Ela tem um estilo popular, meio naif, ingênuo e hoje vende quadros.
Em 1989, começa sua luta contra o mal de Parkinson, numa dura rotina de remédios e fisioterapia. Entretanto, não se deixou abater e continuou produzindo muito nas diversas áreas de atuação. Nem os tremores, conseqüências da doença, abalaram a firmeza de seu traço. Hoje, com o mal em estágio bem avançado, alterna períodos de lucidez e de perda de memória mas ainda realiza trabalhos, principalmente desenhos.

Retraído e avesso às badalações das grandes cidades, Brasília serviu-lhe como uma espécie de refúgio seguro. É certo que a Capital cresceu demais, porém, ainda conserva uma atmosfera de isolamento, conveniente à alma deste artista arredio. Em Brasília não se cobra sua presença em museus e galerias, a ele é permitido certo silêncio (PONTUAL, 1992).

As pessoas que têm ou tiveram contato com Athos Bulcão, tanto em relações de amizade, como em relações profissionais dedicam-lhe muito carinho, respeito e admiração pela pessoa e pelo profissional que ele sempre foi: embora um tanto quanto solitário, muito tímido, extremamente modesto, o tempo todo está sempre cercado de amigos.

Em 1990, Eduardo Cabral ${ }^{13}$ em uma conversa com Athos propôs a criação da Fundação Athos Bulcão. Prontamente, discordou, sempre foi muito negativista, dizia não a tudo, mas ao mesmo tempo, muito carismático, vivia cercado de muitas pessoas. A Fundação, entidade sem fins lucrativos, demorou dois anos para ser registrada; seu capital inicial proveio dos direitos dados à Fundação para a reprodução dos trabalhos do Athos Bulcão.

Cabral (2005) revelou também, algumas curiosidades sobre Athos Bulcão, tais como 0 fato de ter sido franciscano iniciado, quando jovem; tem como característica marcante, a concepção de que a cor é mais importante que a forma e, quando viu pronto o livro Athos Bulcão, de 2001, achou que "podia morrer".

Athos transfere para sua criação as qualidades de seu caráter: afabilidade e cordialidade. Seus painéis de azulejos cumprem função especial em Brasília - cidade, às vezes, inóspita: aproximam, dialogam, oferecem sombra, proporcionam bem estar; não são colocados para preencher algum espaço não resolvido, são pensados desde o início do projeto do edifício (MORAIS, 1998).

Ele é considerado um artista múltiplo, pela sua facilidade em penetrar e trabalhar em diversas áreas das artes plásticas e possuir domínio de técnicas diferentes. Ao longo de sua carreira, além do exercício contínuo do desenho; elaborou figurinos para peças de teatro; desenhou capas de livros e revistas; trabalhou com fotomontagens; criou série de "máscaras", em relevo 


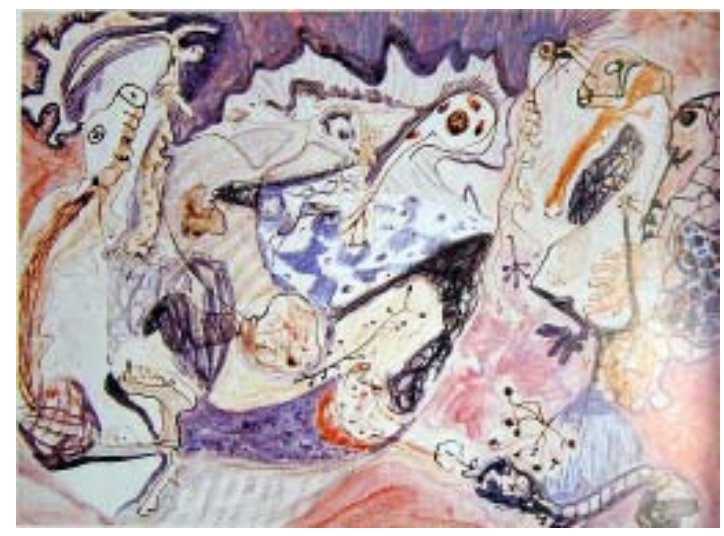

policromado ou durepox pintada em acrílica; criou série de "bichos", mini-esculturas policromadas em durepox com pintura acrílica; sendo a pintura - acrílico sobre tela - a sua atividade preferida.

Nas obras de maior porte e volume, na área da integração com arquitetura, projetou divisórias de ambientes internos, geralmente em madeira pintada ou laqueada; criou muros vazados em argamassa armada, nos hospitais da Rede Sarah, em parceria com Lelé. Além do trabalho com azulejos, um dos objetivos centrais desta dissertação, Bulcão projetou relevos internos e externos em granito, mármore, concreto ou madeira laqueada; criou vitrais e painéis internos em relevo com função acústica, geralmente em madeira e fórmica ou, ainda, fachadas de edifícios em mármore, pastilha ou cerâmica.

Em 1952, Athos começou a produzir fotomontagens, técnica pouco utilizada no Brasil, a não ser pelos trabalhos de Jorge de Lima. Em suas pesquisas fotográficas, extrapolava 0 âmbito das relações formais, uma vez que herdava a carga semântica de imagens extraídas de outras fotos de revistas e livros. Essas imagens eram recortadas e montadas em uma composição inédita e então re-fotografadas, possuíam certo teor surrealista (COCHIARALE, 1998).

"Pessimistas e angustiosas - nessa arte, Athos Bulcão revela sua crítica sarcástica e cruel do mundo e da vida. São fotomontagens dolorosas; expressão de uma época que sofre intensamente, através de recalques e conflitos íntimos, explosões freudianas e falta de fé nos sêres e nas cousas. É, sob êsse aspecto, arte importante e rara no Brasi" (FOTOMONTAGENS..., 1955).

Nos trabalhos de relevos, Athos sai da bi-dimensionalidade seguindo em direção ao tridimensional. O mais famoso deles é o relevo em concreto do Teatro Nacional de Brasília de 1966, onde o artista usa o mesmo raciocínio dos painéis de azulejos. Nos relevos, trabalha com
84. Aquarela $26,5 \times 36,5 \mathrm{~cm}$, sem título, 1942.

Fonte: COCCHIARALE, 1998.

85. Gravura em metal $25 \times 63 \mathrm{~cm}$, sem título, 1974

Fonte: COCCHIARALE, 1998.

86. Sem título, acrílico s/ tela, 1989 acervo da Fundação Athos Bulcão. Brasília.

87. Bichos. Miniesculturas policromadas em durepoxi com pintura acrílica. 1975/1998 Fonte: ATHOS, 2001,p.304
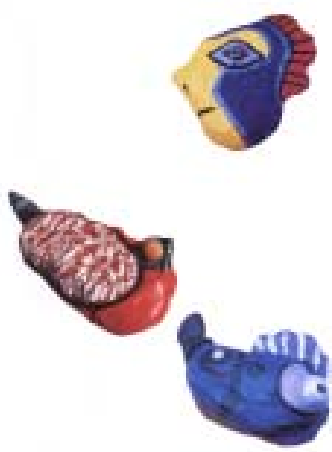

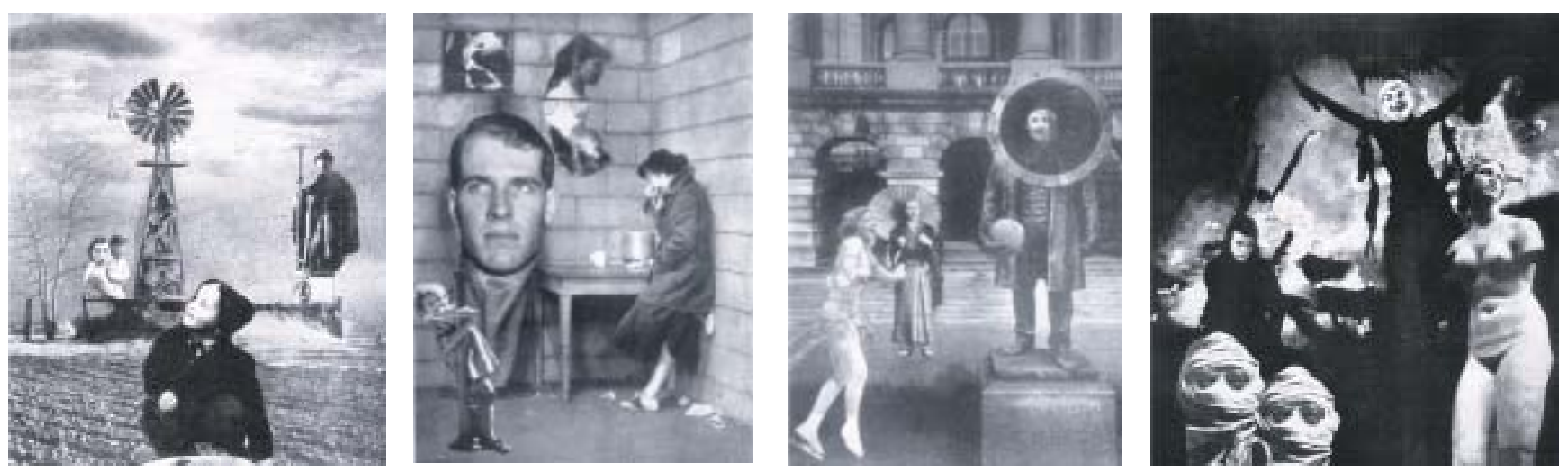

88. Entardecer num planalto. Fotomontagem Fonte: Brasil Arquitetura Contemporânea n5, 1955, p.56.

89. Não vá Jean-Paul Sartre pensar que isto é uma cena surrealista da sua peça "Huis Clos". Fotomontagen. Fonte: Habitat n¹7 jul/ago, 1954

90. Estas figuras que parecem imagens saídas do Corpo de Dados

de Max Jacob, sobraram de uma prova atômica. São: a patinadora à procura dos Alpes, o escafandrista à procura do mar e o mágico à procura das crianças. Fotomontagen.

Fonte: Habitat n017 jul/ago, 1954, p.61.

91. Sábado no purgatório Fotomontagem. Fonte: Brasil Arquitetura Contemporânea n ${ }^{\circ} 5$ 1955, p.56.
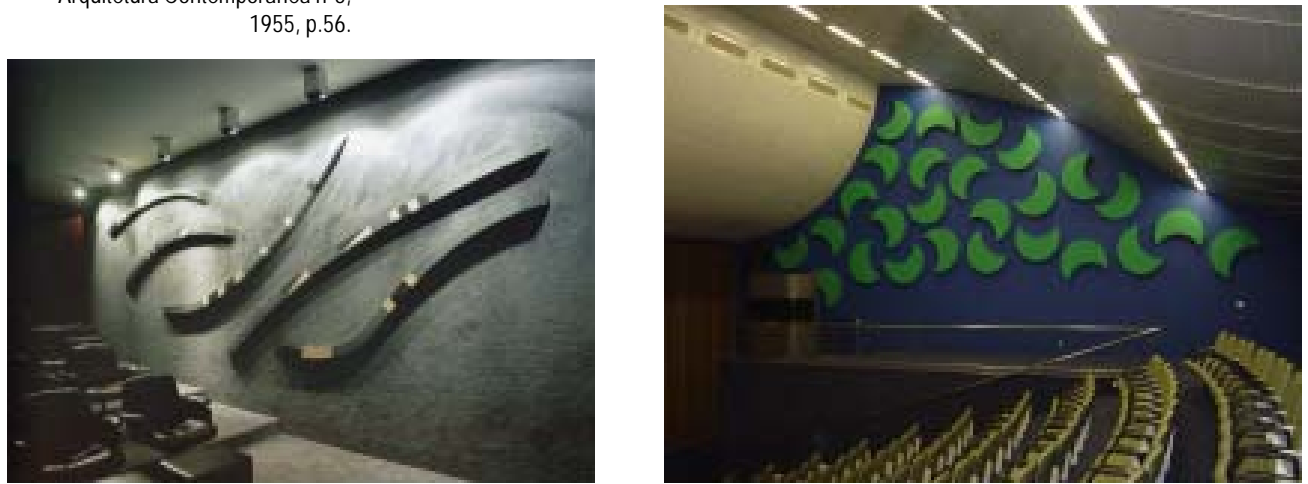
no tamanho, na disposição e raramente nas cores. módulos geométricos numa seqüência de repetição, com pequena variação de módulos, mas na disposição consegue a diversidade. No relevo, em mármore, do Supremo Tribunal Federal de 1969, é usada apenas a repetição de um módulo. Nos relevos com função acústica, ele reduz tanto a modulação, quanto as cores, utilizando apenas um módulo geométrico, variando às vezes

Athos enobrece os ambientes com suas interferências em relevo, tirando a monotonia de corredores e auditórios, com seriedade e elegância. Nos relevos de 1997 do auditório de Tribunal de Contas da União em Belo Horizonte, no cinema do Palácio Jaburu de 1975 e no Cine Brasília de 1976, foge da sua composição modular usual, mas continua usando formas geométricas.

92. Relevo de função acústica em madeira pintada, mármore e granito. Cinema Palácio do Jaburú, Brasília, 1975.

Fonte: ATHOS, 2001, p.149.

93. Relevo de função acústica. Auditório Hospital Sarah Norte. Brasília. 1998

94. Relevo em mármore do Supremo Tribunal Federal. Arq. Hermano Montenegro. Brasília, 1969. Fonte: ATHOS, 2001, p.107
O raciocínio usado por ele para seus muros vazados e divisórias parece seguir a mesma seqüência de repetição de módulos geométricos, porém, estes possuem disposição e formato mais vertical e a presença constante de espaços vazados, proporcionando visualização dos ambientes, evitando-Ihes isolamento. São muros e divisórias vazadas que aproveitam o uso, ou passagem de luz. Nas primeiras divisórias, como no Palácio do Itamaraty, 1967, Athos usa treliça 

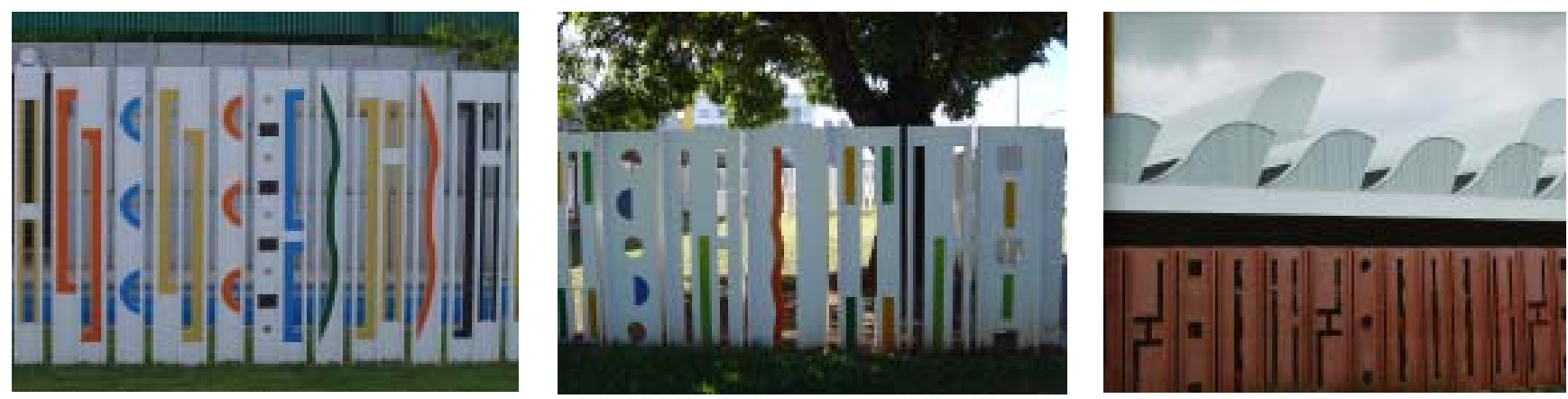

fina e madeira e apenas quatro cores; no muro escultórico do Salão Verde da Câmara dos Deputados de 1976, apenas um módulo geométrico vazado, numa composição parecida com a dos azulejos, meio aleatória.

As divisórias internas são geralmente módulos confeccionados em figuras geométricas vazadas, em madeira pintada, onde o artista usa, mais uma vez, a combinação de poucas cores: uma, duas ou três diferentes. Os muros são também módulos com figuras geométricas vazadas, confeccionados em argamassa armada e seguem seqüência de repetição dos módulos, às vezes de uma cor só, como no Tribunal Regional Eleitoral de Salvador, outras vezes, em várias cores alegres e combinadas, incluindo o branco, tal como nos hospitais da rede Sarah.

De acordo com Pontual (1992), o ponto de partida na obra de Athos Bulcão, a sua marca maior está a predileção pela multiplicidade de material e de suportes: o papel, o lápis, a tela, a tinta, a cerâmica, o cimento, o mármore, o gesso, a massa de modelar. Por outro lado, há concentração necessária para que o múltiplo alcance o uno, a dispersão não é permitida, trabalha com rigor e com humor.

Athos iniciou sua carreira pelo desenho e pintura, dentro das tendências figurativas. As questões referentes a cor foram sempre seu principal ponto de atenção e conhecimento,
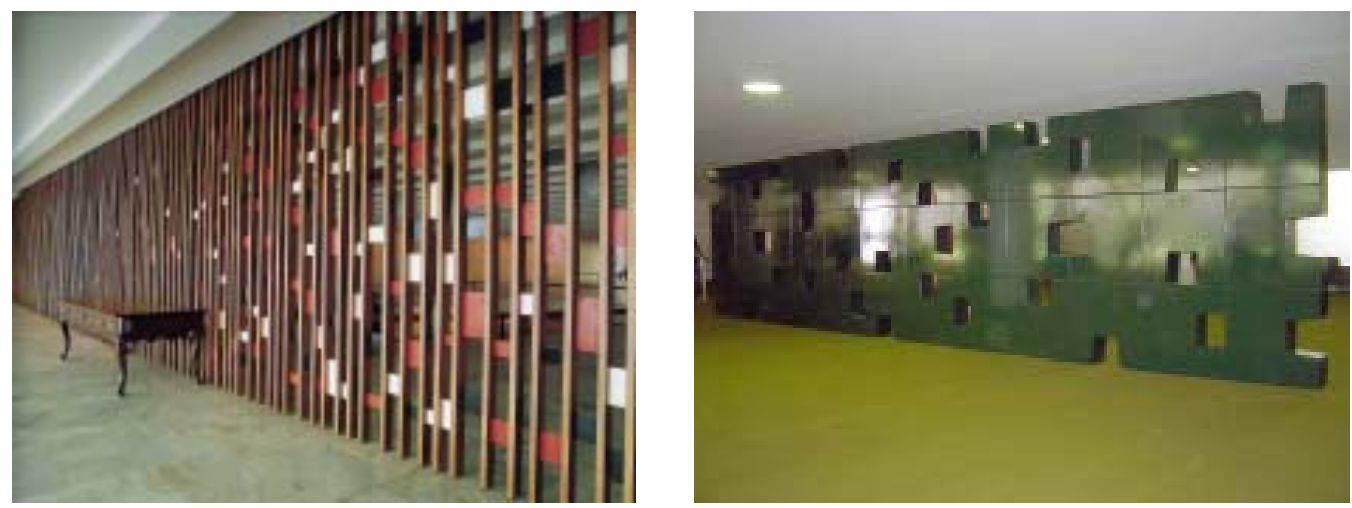

95. Muro vazado em argamassa armada. Hospital Sarah Norte. Rede Sarah de Hospitais do aparelho locomotor. Arq. João Filgueiras Lima. Brasília, 1998.

96. Muro vazado. Argamassa armada Painel de azulejos. Hospital Sarah Centro.Rede Sarah de hospitais do aparelho locomotor Arq.João

Filgueiras Lima. Brasília, 1981.

97.Muro vazado em argamassa armada. Tribunal Regional Eleitoral de Salvador. Arq. João Filgueiras Lima, 1997.

Fonte: ATHOS, 2001, p.221.

98. Divisória em treliça de madeira e ferro. Palácio do Itamaraty. Arq. Oscar Niemeyer. Brasília, 1967. Fonte: ATHOS, 2001, 97.

99. Muro escultórico em madeira laqueada. Salão Verde da Câmara dos Deputados. Arq. Oscar Niemeyer, Brasília,1976. 
dedicando-Ihes longo aprendizado. Contudo, foi pelo exercício da integração com a arquitetura que seu trabalho enveredou por rumos diferentes. Sua intensa colaboração em projetos arquitetônicos the abriu novas perspectivas. A melhor resolução visual que se apresentou, devido às necessidades impostas por essa atividade, foi a geometria que, paulatinamente, tomou lugar também na sua pintura (TELLES, 1992).

\section{Integração na arquitetura e anonimato da obra pública}

A obra de Athos Bulcão encontrou maior dimensão e, consequentemente, maior aceitação e reconhecimento no seu trabalho de integração com a arquitetura. Ele próprio admite que começou a aprender e entender melhor a arquitetura com Oscar Niemeyer. Depois o aprendizado se deu com a prática, sempre experimentando, testando... Com muita disciplina e trabalho, foi conseguindo o melhor resultado em cada projeto. Sempre trabalhou a convite dos arquitetos e amigos, dentre os quais se destacam Oscar Niemeyer e Lelé; também trabalhou em parceria com Sérgio Parada, Haroldo Pinheiro, Cláudio Queiroz, Persina, Glauco Campelo, Hélio Uchôa, entre outros ${ }^{14}$.

Em relação a sua parceria com Oscar Niemeyer, Athos diz que ele e Niemeyer são como o diretor Fellini e o compositor Nino Rotta, isto é, se complementam. "Me senti Nino Rotta e Oscar Niemeyer, Felini, eu fazendo uma música importante naquela obra" (ATHOS..., 1998). "O meu amigo compreendia como ninguém a nossa arquitetura e nela se inseria com sua habilidade invariável. Inúmeros foram os trabalhos que para mim executou, todos marcados pela simplicidade e beleza que tão bem dominava" (NIEMEYER, 1998, p.2).

Athos tem enorme compreensão do espaço, da concepção do ambiente. Na maioria das vezes participa no projeto desde o início, o que, sem dúvida, ajuda na integração do trabalho. Muitas vezes, pela sua experiência, faz sugestões de cores e materiais que os arquitetos acabam aceitando plenamente e que realmente interferem no ambiente, sempre complementando para melhor solução arquitetônica. Mesmo hoje, embora com limitação de saúde, participa de pequenos projetos que não impliquem no acompanhamento das obras.

"A atitude de Athos está nas ruas. Técnica e sensibilidade. Converte-se na própria obra como está exposto e integrado ao conceito de arquitetura. Supera o suporte: não enfeita parede, a justifica. Às vezes, é a construção que adquire sentido a partir da intervenção de

${ }^{14}$ Ver Apêndice 2. Athos. Meigo e sagaz, ele compõe cada traço sob longa percepção do meio: absorve para depois criar. Afável em extrema paciência... Athos cultiva silêncios enquanto abre grandes planos monumentais" (CATALÃO, 2004). 
Brasília, cidade que recebeu Athos Bulcão, que, por sua vez, se encantou pelo seu solo, seu ar, seu pôr do sol, tornou-se a escolhida como moradia. Aqui se encontra a maior parte de suas edificações, intimamente ligadas à arquitetura, pode-se dizer que figuram entre as mais belas da arquitetura brasileira.

"Sem dúvida alguma, a criação plástica de Athos, a reeducar o olhar, do brasiliense, abrindo sua percepção para valores estéticos mais altos que os da cultura de massa e do consumismo, está melhorando a qualidade de vida de Brasília, reafirmando, ao mesmo tempo, a vocação democrática da obra de arte" (MORAIS, 1998, p.3).

Athos Bulcão é um artista com enorme sensibilidade para trabalhos em espaços públicos, produzindo obras que se incorporaram à paisagem e se encontram acessíveis aos cidadãos, aos passantes em geral, não gosta da obra confinada em museus, feita para apreciação de poucos (FRANCISCO, 2001). É a favor da democracia, da arte social feita para o povo, talvez integrado também ao contexto político vivido por ele. O interesse e o respeito de Athos focam-se no público que entra em contato com sua obra por acidente, no transeunte, a caminho de casa ou do trabalho, naquele que não tem conhecimento algum de artes plásticas. É a ele que Athos consagra sua trajetória artística.

A arte pública geralmente aparece para resolver uma carência ou um problema da arquitetura e do urbanismo. O movimento moderno, defensor da síntese das artes, na maioria dos casos usa a pintura e a escultura sem perder sua autonomia, isto é, elas são usadas para adicionar beleza e não porque se confundem com a arquitetura e com o espaço público. As obras de Athos, por sua vez, vão ao encontro a essa situação comum. Seus murais, relevos, divisórias, portas, paredes, não se afastam da arquitetura que os recebe, que os compreende. Seus murais potencializam e enamoram-se da arquitetura (FARIAS, 2001). "Eu nunca tive dúvida nenhuma que a sensibilidade do Athos é enorme para entender o espaço arquitetônico" (PARADA, 2005).

Apesar dos períodos de estágios, estudos e aprendizados com outros artistas, Athos foi sempre autêntico, um tanto quanto autodidata, construiu seu próprio modelo. Sempre possuiu disposição para experimentar, o que o levou a caminhos plurais de meios e atividades tão diversos, que o separaram, aos poucos, tanto da tradição modernista da qual veio, como também do abstracionismo radical e até mesmo do ambiente cultural do Rio de Janeiro. A abstração informal e o construtivismo (concretismo e neoconcretismo) foram essenciais para a renovação da arte brasileira. Pela primeira vez, a produção artística nacional estava em sintonia com as vanguardas 
internacionais. Para Athos Bulcão, o aprendizado formal da arte abstrata, exigência essencial para a formação do artista brasileiro, se tornou mais intenso no momento em que se transferiu para a Nova Capital em construção (COCCHIARALE, 1998). O repertório de Athos Bulcão na sua obra de integração arte/arquitetura é análogo ao dos artistas pertencentes às linhas construtivistas brasileiras.

"Não se estava mais, com referencia à arte, no campo da criação, mas no âmbito da invenção: o jogo consistia em manipular inventivamente as formas, produzir uma ordem maximal de informações visuais, estabelecer processos semióticos que forçassem 0 espectador a romper os esquemas convencionais de percepção e exercitar-se na nova ordem proposta. Há uma valorização dos efeitos da pesquisa e invenção de formas, há uma fé 'na potencialidade social da criação formal'. Frente ao esquema tradicional, a arte concreta coloca-se de modo análogo às da poesia concreta diante do 'velho alicerce formal e silogístico-discursivo' da poética convencional e discursiva. Em ambos os casos, a questão é romper um esquema formal dominante e todo o sistema de significações dele necessariamente solidário". (BRITO, 1985, p.36).

Athos trabalha com o arquiteto e a equipe desde o momento da definição do espaço da sua obra na planta do edifício ou do local. Fala de um "princípio de composição" a ser livremente executado pelos operários. Pode-se dizer que hoje, são os azulejos que influenciam sua pintura, embora goste mais de pintura (MORAIS, 1988).

Por intuição, Athos opta pelas formas abstratas em seus trabalhos de intervenção arquitetônica. Sua preocupação está em usar poucos elementos e uma escala perfeita e equilibrada. Segue a experiência de Fernand Leger, que prefere usar uma composição abstrata em grandes quadros e a figura humana em pequenos espaços (FRANCISCO, 2001).

"Athos é, sem dúvida, o artista plástico do nosso tempo que mais realizou as previsões de Fernand Leger de que os pintores no decorrer deste século iriam incorporar seus trabalhos aos espaços urbanos e aos edifícios. A rigor, ele foi muito mais além, porque não os incorporou como simples adornos ou complementos decorativos, mas os tornou fortemente ancorados e integrados à própria arquitetura". (LIMA, 1998).

Uma das obras mais citadas e famosas, que exemplifica bem o entrosamento do trabalho do Athos à arquitetura é 0 Teatro Nacional de Brasília. Para as fachadas laterais, 0 artista criou 0 painel com blocos de concreto que formam um jogo de luz e sombras. Inicialmente, Niemeyer 

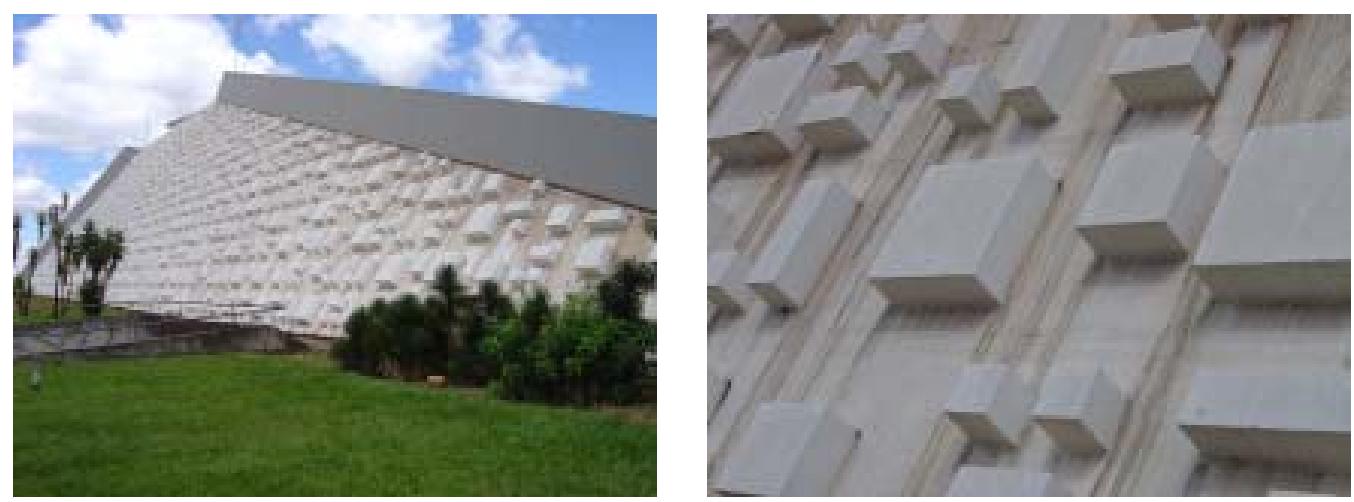

100. e 101. Relevo externo em concreto do Teatro Nacional Cláudio Santoro. Arq. Oscar Niemeyer. Brasília, 1966.

pensou em um grande painel de azulejos, depois se decidiu por uma solução em relevos. 0 prazo para criação e execução foi muito curto. Athos adotou a idéia de diversos cubos quadrados e retangulares usando apenas a cor branca. Neste relevo em concreto utilizou-se o mesmo processo dos azulejos, ou seja, o ponto de partida é uma estrutura modular, neste caso um todo com partes medidas e coerentes, organizadas segundo relações numéricas, posicionadas proporcionalmente para serialização. Sob a incidência do sol do planalto de Brasília se estabelece um jogo de luzes e sombras, que transforma o painel a todo o momento, modificando suas formas de acordo com a luz sobre o branco, salientando os volumes e planos, multiplicando a linguagem da geometria (FREITAS, 1997).

"O relevo das fachadas laterais do Teatro Nacional, realizado nos anos 60, é considerado um momento maior na obra de Athos Bulcão. Tanto por sua grandeza física, com $120 \mathrm{~m}$ de base e $27 \mathrm{~m}$ de altura, quanto pela imponente presença do painel relevo em relação ao edifício e à própria cidade. Esta forte presença ressalta a grande confiança existente entre 0 arquiteto e o artista: o painel define esteticamente o edifício. Houve uma perfeita comunhão de intenções, é difícil saber o que pertence ao arquiteto e o que pertence ao artista"(TELLES, 1997).

Pode-se observar que, algumas características existentes nas obras de Athos Bulcão são a utilização dos padrões de azulejos como módulos para compor os painéis, assim como a repetição destes módulos criando o ritmo com formas e cores.

Os projetos de Athos Bulcão em parceria com João Filgueiras, o Lelé, para a rede de hospitais Sarah Kubitschek podem ser considerados grande acervo de integração da arte com a arquitetura. Foi um feliz encontro profissional, pois o processo de construção do Lelé é modular e 

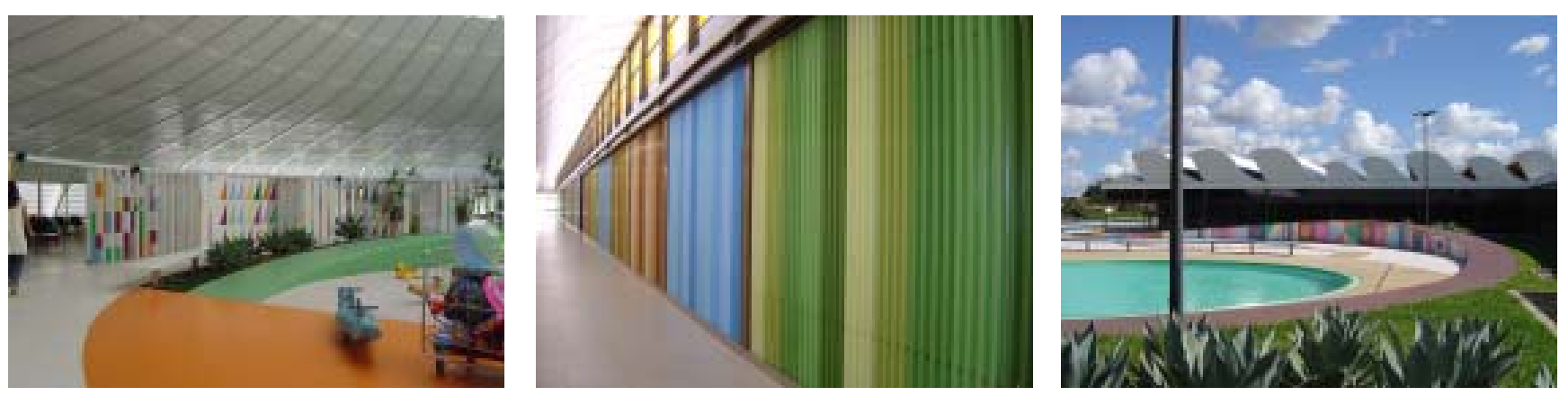

102. Divisória/painel da creche do Hospital Sarah Norte. Rede Sarah de Hospitais do aparelho locomotor. Arq. João Filgueiras Lima. Brasília, 1999.

103.Divisória Hospital Sarah Norte. Rede Sarah de Hospitais do aparelho locomotor. Arq. João Filgueiras Lima. Brasília, 1999.

104. Pintura na rampa de exercícios Hospital Sarah Norte. Rede Sarah de Hospitais do aparelho locomotor. Arq. João Filgueiras Lima. Brasília, 1998. dialoga com o processo de criação do Athos Bulcão. Além disso, o trabalho possui a função social de auxiliar o bem-estar dos pacientes e visitantes (TELLES, 1997).

Lelé desenvolve uma arquitetura fundada em componentes industrializados, voltada para a necessidade existente no Brasil de obras de infra-estrutura urbana, e de edifícios públicos tais como escolas, hospitais e instituições. Em relação a esse binômio: arquitetura - indústria, a obra de Lelé pode ser considerada, senão única, a melhor. Possui alto teor estético, ainda que realize um produto de baixo custo, em escala industrial. Lelé cuida desde o refinamento formal, como de detalhes, está atualizado com a tecnologia construtiva de ponta, se preocupando até com algumas referências às nossas tradições culturais (FARIAS, 2001).

Em sua obra de integração da arte com a arquitetura, Athos Bulcão atinge os preceitos necessários que são 0 de deixar 0 arquiteto e o edifício como autores e 0 artista, 0 colaborador, mas sabe tornar esta colaboração essencial (TELLES, 1997). Para Costa (1987), a integração das artes e da arquitetura ocorre quando o artista convidado a resolver certos espaços propostos pelo arquiteto, o faz de maneira harmônica, além de compor, a obra se confunde com o espaço criado pela arquitetura.

"As obras de integração com a arquitetura de Athos Bulcão reafirmam o seu valor exatamente por sua verdade: elas estão, estética e filosoficamente, comprometidas com as propostas do projeto arquitetônico. Longe de encarar o espaço onde seu trabalho será inserido como suporte passivo, ou como uma excepcional oportunidade para investir no gigantismo e destacar individualmente seu produto, Athos trabalha 'em função' desse espaço, a partir da arquitetura, destacando-a, valorizando-a, criando jogos de ver e pensar que aumentem a sua riqueza e seu valor" (COSTA, 1987).

"A produção de Athos Bulcão, que desembarcou no cerrado em 1958 e fez de Brasília sua casa-ateliê, mergulha na plástica refinada, no inusual jogo de escala e movimento entre 0 
corpo do espectador e a obra, no sublinhar da arquitetura dos edifícios que interfere. Volta-se para os espaços públicos, derramando-se no cotidiano e no imaginário da população. Não decora, cria espaços e formas, capta o olhar para o surpreendente" (RAMOS, 2002).

"Tudo, enfim, aponta para uma espécie de cumplicidade entre os projetos do artista e do arquiteto. A composição de Athos Bulcão busca e encontra seu lugar no espaço desenhado pelo arquiteto, tornando-se, em muitos momentos parte indissociável deste. A tal ponto que decididamente não há como ignorar a presença do seu trabalho na cena de Brasília. Um sentido nitidamente urbano o faz complementar a paisagem estruturada por Lúcio Costa, quer nos desenhos dos letreiros luminosos do centro comercial, quer nos incontáveis painéis que penetram a vastidão da cidade, e nela habitam" (NOBRE, 1999, p. 43,44).

Athos Bulcão ainda não foi reconhecido como um dos nossos melhores artistas, talvez em conseqüência da própria opção em trabalhar com obras ligadas aos espaços públicos, que se confundem com os edifícios e com a natureza. Certamente deve ser conhecido pelos habitantes de Brasília, por ser o criador dos relevos do Teatro Nacional, e talvez eles não associem a seu nome outras obras que se espalham pela cidade, tão próxima das pessoas, tão familiar pelo contato cotidiano, que já nem percebem que se trata de obra de arte.

A esse artista não interessa sua mitificação, há certa negação da autoria em sua obra, no momento que não assina seus painéis, na medida em que prefere 0 anonimato, deixando que sua obra seja consumida do jeito que planejou, ou não planejou, quando os operários interferem e contribuem na composição do painel, como trataremos a seguir. Nesse momento 0 artista se preserva, numa postura não vaidosa.

No decorrer da pesquisa, constatamos ser Athos Bulcão um nome conhecido e respeitado no universo das artes plásticas, sua obra tem aceitação e valor comercial. Essa aceitação devese também a sua fama, mesmo por aqueles, que não tenham formação artística ou acadêmica e que, talvez não consigam assimilar o trabalho de Athos Bulcão. Segundo Parada (2005), "... um nome como Athos Bulcão, é mais fácil para aceitação, porque seu trabalho já é de domínio público. Então, as pessoas não colocam dúvida sobre o trabalho, mesmo quem não goste".

A pessoa de Athos Bulcão também não é popular, ele pode passear livremente pela cidade, mantendo seu anonimato, porém, segundo Valéria Cabral ${ }^{15}$, seguramente ele será reconhecido imediatamente num Centro Cultural, biblioteca ou lugares relacionados ao mundo

${ }^{15}$ Valéria Cabral além de outras funções é responsável pelo acervo de obras de Athos Bulcão. 

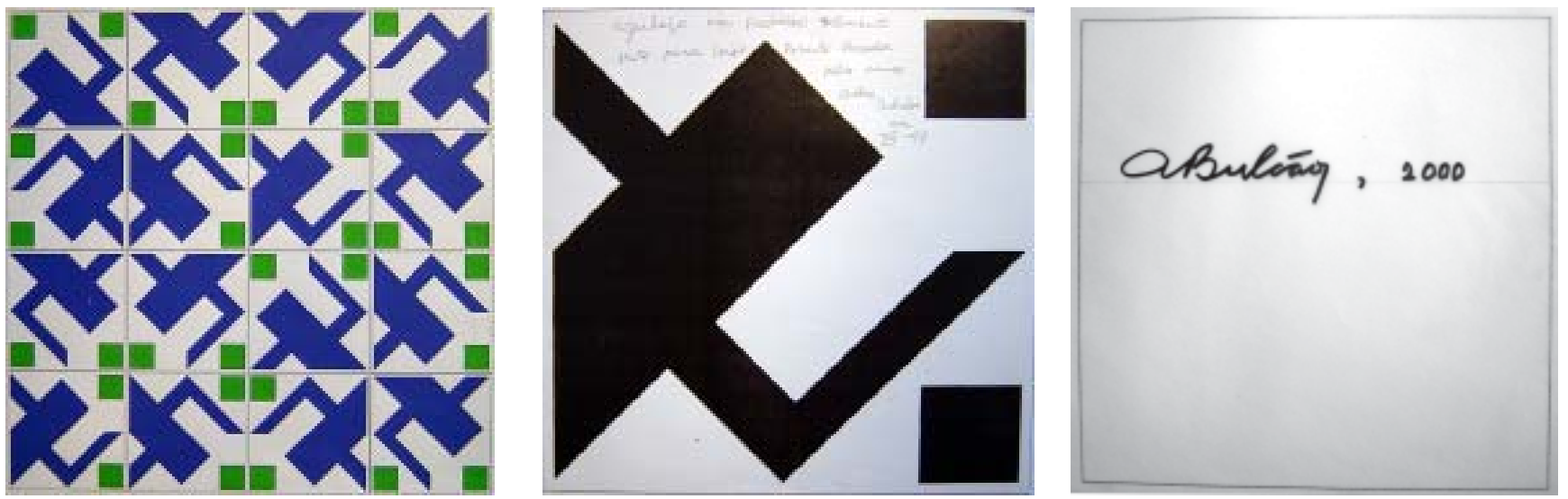

105. Serigrafia "Sequência azulejo padrão B".

106. Desenho de azulejo para residência de Sérgio Parada, Brasília,1999. Acervo de Sérgio Parada.

107. Assinatura de Athos Bulcão para painel de azulejos da residência de Sérgio Parada, Brasília, 2000. Acervo de Sérgio Parada.

artístico. Dentre aqueles que o conhecem bem, tais como os estudantes de artes plásticas, teatro, etc., todos o tratam com muito respeito e admiram seu trabalho. Sua privacidade é preservada tanto pelos amigos próximos como pelos colaboradores, como pudemos observar nas dificuldades encontradas para a consecução de contatos na elaboração desta pesquisa.

Sua opção de se transferir para Brasília, escolhendo-a como sua cidade, em detrimento do Rio de Janeiro com todo seu fervor e agitação artística e cultural, demonstra a personalidade tímida e silenciosa do artista, cuja obra reconhecida e elogiada pela maioria dos críticos de arte e a quem denominam de "humanizador de espaços", "construtor de espaços", "habitante do silêncio", "mestre das cores", "o artista de Brasília", artista que, no silêncio e exílio voluntário em Brasília, vem dedicando sua obra ao bem estar do povo.

Na sua integração com a arquitetura Athos firma sua marca própria que se mantém inconfundível. Mas se desinteressa da assinatura, talvez por se manter fiel à idéia norteadora de Brasília, a cidade como obra de arte coletiva, resultado da colaboração de arquitetos, urbanistas,

108. e 109. Painéis em azulejo. Residência Sérgio Parada. Foto: acervo Sérgio Parada.
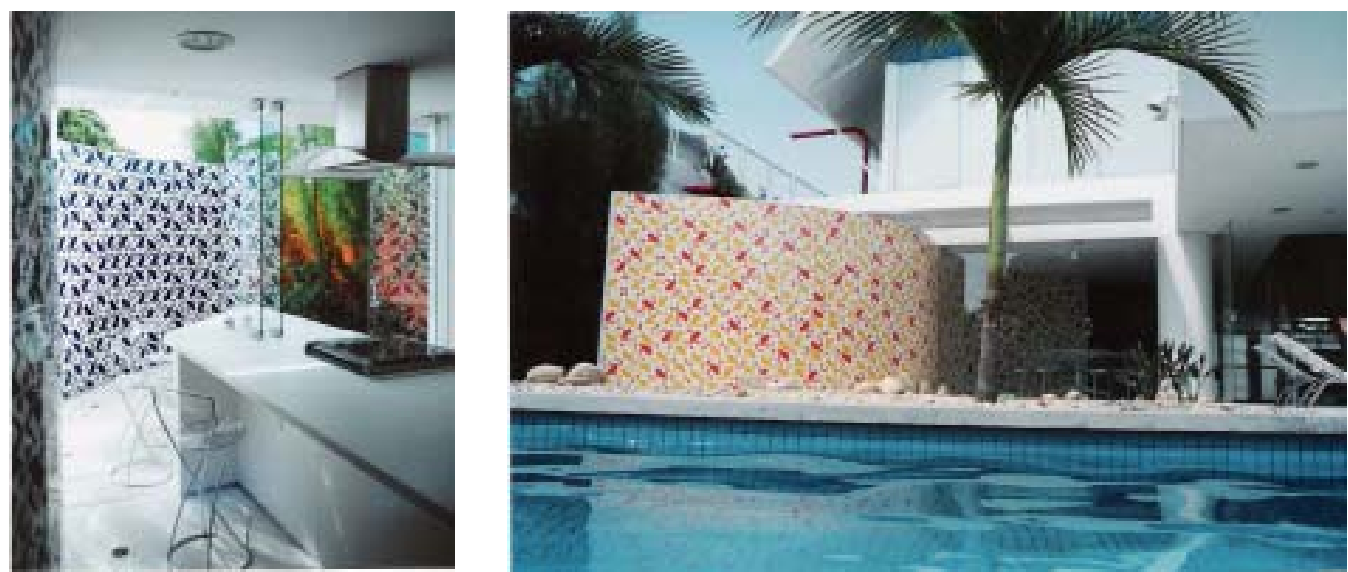
pintores, escultores (NOBRE, 1999). Um dos poucos painéis assinados foi o da casa do arquiteto Sérgio Parada, mas por ser um presente, uma lembrança, uma obra particular, não pública. Para enfatizar que era um presente Athos usou nesse painel as mesmas cores que usara no painel do aeroporto, um projeto de Parada.

Em contrapartida a essa postura de Athos Bulcão, surgiu um grupo de pesquisadoras de Brasília com apoio da Fundação Athos Bulcão, inventariando as obras do artista: Tatiana Petra, Lana Guimarães e Patrícia Herzog. Elas elaboraram um projeto chamado Brasiliathos, um roteiro cultural pelas ruas de Brasília; inventariaram obras tanto dos espaços públicos como as dos privados, incluindo tanto as conhecidas paredes de azulejos e painéis ou trabalhos que passam despercebidos. Paralelamente, montaram também um projeto de educação patrimonial, chamado de Circuito Educativo Brasiliathos, com objetivo mais amplo, o de sensibilizar a população para a valorização dos nossos bens patrimoniais, os riscos de depredação do patrimônio e importância da qualidade de vida gerada do aspecto artístico-cultural da cidade pela integração arte-arquitetura das obras do mestre Athos Bulcão. Esse projeto contou com patrocínio dos Correios e atendeu a alunos de $3^{a}$ série de Escolas-classe e educadores de Escolas-parque. Apesar do apoio institucional da Unesco, da Fundação Athos Bulcão, da Secretaria de Turismo, do Instituto do Patrimônio Histórico e Artístico Nacional (Iphan) e do Departamento do Patrimônio Histórico e Artístico do GDF (DEPHA), ainda não foi possível a publicação e a comercialização do inventário e sua transformação em formato de guia para o trabalho voltado ao turismo cultural.

\section{Composição, processo criativo, temas e cores na azulejaria de Athos Bulcão}

O método construtivo do artista, que marca grande parte de sua produção, é a criação em série, utilizando elementos repetidos. É através do artesanal que nascem seus trabalhos, obedecendo a um método racional, a um princípio determinado em busca da clareza e objetividade. Um processo que junta a poética e o mistério da beleza (ATHOS..., 2004).

Nos painéis de azulejos, o módulo, a unidade mínima e indivisível se mantém, pois o desenho está sempre dentro dos limites da peça de azulejo, geralmente quadrada, $15 \times 15 \mathrm{~cm}$ ou $20 \times 20 \mathrm{~cm}$. Porém, ao unir uma peça as outras quatro, e assim sucessivamente, o desenho se interrompe e passa dos limites iniciais, ganhando escala imprevista, multiplicando-se virtualmente 
110. Desenho de módulos do painel de azulejos do Hospital Sarah Kubitschek-São Luiz do Maranhão. Representação do esquema de variação $3 \times 1$ Fonte: Bien'Art, 2006, p. 16

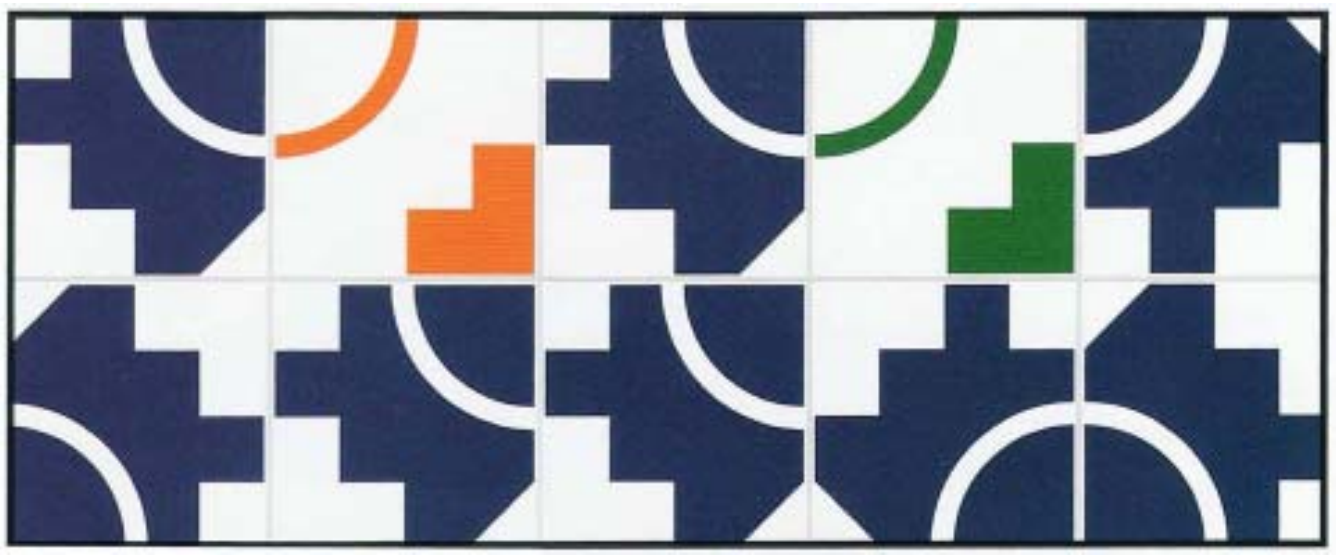

ao infinito e resultando na expansão do desenho para a escala urbana, sem perda de peso ou complexidade. Ao olhar, de imediato se vê o todo, em seguida se vê a parte, depois com um olhar mais atento se notam as relações estabelecidas entre eles, de uma análise combinatória que guia a composição. Em alguns painéis, a colocação que parece aleatória, resulta de um padrão estabelecido: $3 \times 1$, quando a cada quatro peças, apenas uma pode ter variações (NOBRE, 1999).

A combinação dos módulos, na maioria dos painéis é aleatória, mas surpreende à medida que mantém certa uniformidade, tanto nas cores, como nas formas. Em certos painéis, o desenho geométrico do módulo lembra um logotipo, como no Clube Congresso de 1972. Em outros, os

111. Desenho técnico de azulejo para residência Aloysio Campos da Paz. Acervo de Haroldo Pinheiro

112. Detalhe dos azulejos do Clube do Congresso. Brasília,1972.

113. Reprodução de azulejos do Brasília Palace Hotel. Fonte: Módulo, Rio de Janeiro, ago. de 1958 , v.2, n.10, p.28. módulos encaixam-se formando uma seqüência geométrica, como na Assembléia Legislativa do Distrito Federal de 1991, no qual se vê claramente a intenção da composição do artista. As linhas e curvas dos módulos, às vezes, dão continuidade, às vezes, rompem-se.

A intenção de Athos é sempre qualificar o espaço, dar aos usuários a sensação agradável de leveza, alegria, às vezes tenta fazer uma ligação da função do ambiente com a composição do
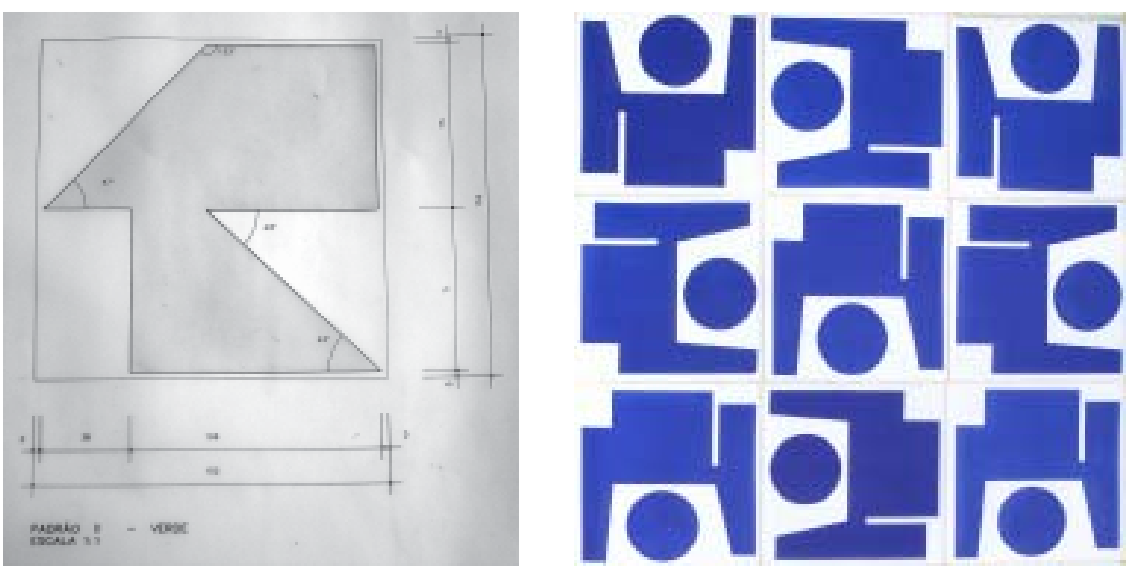

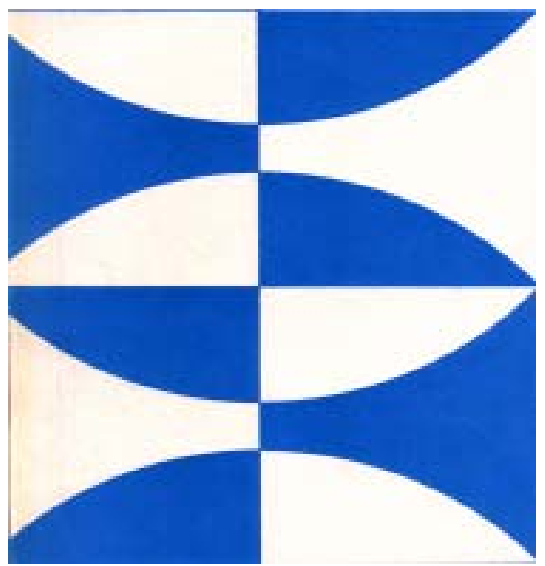



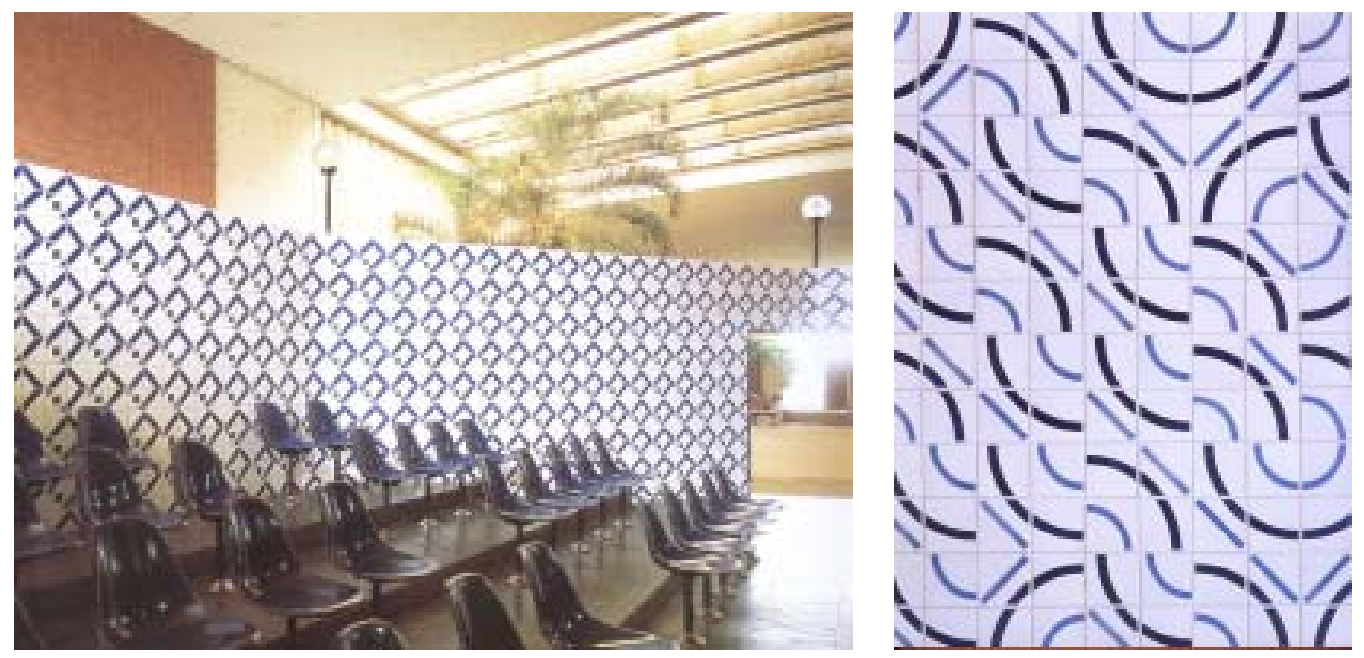

114.Painel de azulejos.

Assembléia Legislativa do Distrito Federal, Brasília, 1991.

Fonte: ATHOS, 2001, p.194.

115. Painel de azulejo. Anexo IICobertura. Palácio do Itamarati. Arq. Oscar Niemeyer. Brasília. 1983.

Fonte: ATHOS, 2001, p.103.

painel que interage com o ambiente dando sentido ao espaço, como no Sambódromo de 1983, onde as curvas dos módulos do painel lembram as curvas das mulatas do carnaval do Rio.

A complexa depuração cromática e a modularização como recurso constante são os elos de ligação que 0 artista imprimiu em suas múltiplas manifestações. Seus painéis se desenvolvem a partir de módulos centrais, desdobramentos que obtém com o azulejo. Por meio de uma forma mestra, que se multiplica pela disposição no espaço, cria movimento e harmonia (TELLES, 1992).

Segundo Morais (1988), apesar dos vínculos com o passado, padrões geométricos da azulejaria portuguesa de séculos passados e a abstração de arte mourisca "Athos é o mais radical criador de azulejos", o que melhor compreendeu sua presença na arquitetura moderna no Brasil. Muito discreto em sua criação, soube enfrentar com ousadia e inventividade tanto espaços internos, como espaços externos. Penetra o moderno inclusive através de questões industriais e econômicas, pois, tanto o fator tempo como o fator econômico fez com que em suas composições, geralmente, fossem usados $1 / 3$ do total de azulejos brancos, como por exemplo, no painel do Congresso Nacional.

"Partindo sempre de formas geométricas simples, de linhas retas ou curvas, dispostas de várias maneiras, Athos alcança uma notável riqueza vocabular. Some-se ainda o ritmo musical dos arranjos, a movimentação contínua que não permite ao olho descansar, pois que está sempre a descobrir novos desenhos, compondo, descompondo e recompondo 0 edifício visual num processo ativo de participação" (MORAIS, 1988). 
O emprego de azulejos feito por Athos contém uma profunda noção da história. Pode-se dizer que os azulejos do Athos passam por referências dos marcos históricos como Pampulha, 0 prédio do MES, os azulejos do Brasil Colonial, vindos de Portugal e Holanda, como também, 0 revestimento do espaço do sagrado, nas igrejas antigas. Athos inscreve o azulejo como módulo e signo de arquitetura, a cor integrada à luz do prédio, "propõe que sua obra se integre integralmente ao todo. Sabe evitar ressaltar a obra, contrastá-la com o prédio". Sabe evitar que o edifício seja suporte para o painel, no entanto, sabe ser necessário na medida certa (HERKENHOFF, 1987).

Além disso, os painéis de Athos são sempre abstratos, a composição modular, as cores são puras e planas, prevalece um distanciamento ideológico e emocional. Pode-se dizer que um painel de Athos é visualidade pura, apenas forma, cor e ritmo (MORAIS, 1998).

Cabral (2005) revela que Athos freqüentou o carnaval do Rio, participou dos desfiles de corsos, em carros abertos, seu trabalho é pleno dessas referências, de figuras travestidas, ele é apaixonado por carnaval, mas que gosta mesmo é pintar. Em seguida vem essa brincadeira de integração arte arquitetura, o lúdico. Indagado, certa vez, por um jornalista em que se inspirara para criar as treliças do Itamaraty, respondeu: "eu não me inspiro, sento e trabalho".

Depois que se transferiu para Brasília, em 1958, como funcionário da Novacap, Athos Bulcão recebeu a tarefa de recobrir as fachadas da Igreja de Nossa Senhora e Fátima, também chamada a igrejinha de Dona Sarah, projeto de Niemeyer. Esse trabalho desencadearia o processo de abstração na sua obra de integração à arquitetura, abandonando o figurativo e sua subordinação ao tema e concentrando-se na operação de funcionamento do plano arquitetônico, fixando-se na geometria. Athos não chegou a aderir às manifestações mais radicais do abstracionismo, instalado a partir dos anos 50, no eixo Rio - São Paulo. "A seu modo, e naturalmente informado pelos movimentos de renovação artística no Brasil, Athos Bulcão constrói uma obra muito pessoal, única, que ganha intensidade justamente em torno dos problemas inerentes à produção arquitetônica moderna em Brasília" (NOBRE, 1999). As intervenções abstrato-geométricas de Athos o colocam entre os maiores artistas da linha construtiva - concretos e neoconcretos ${ }^{17}$.

Os murais e intervenções de Athos são jogos visuais que perturbam o olhar, são jogos lúdicos, onde a genialidade é a simplicidade. Com padrões simples, consegue um resultado surpreendente. Os painéis geométricos geralmente são constituídos por módulos de formas

${ }^{16}$ Para entender melhor o conceito de arte neoconcreta, a qual perpassa no trabalho do Athos Bulcão, ver Amaral (1977, p.83). fechadas, lineares ou circulares, polígonos complexos e coloridos. Curvas e retas, círculos e quadrados que se encaixam e desencaixam num ritmo alucinante e cortado, numa harmonia que 

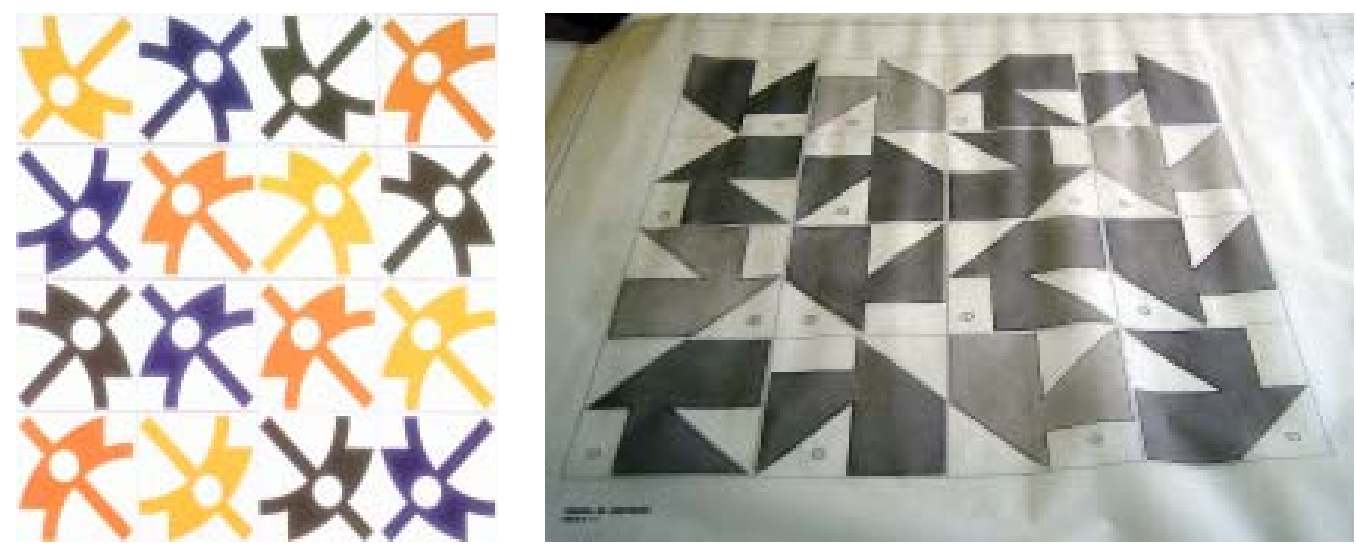

seduz o olhar, pois numa desordem e combinação aleatória consegue manter uniformidade e equilíbrio.

Para Morais (1988) Athos resgata para a arquitetura contemporânea a melhor tradição luso-brasileira. Por outro lado, na opinião de Francisco (2001), não recorre a nenhuma tradição, desenvolveu uma estética moderna do azulejo na arquitetura, usando sempre o geométrico de maneira sintética, pesquisando o uso das formas e das cores e seus efeitos nos espaços públicos. O primeiro e único trabalho com simbologia figurativa foi a Igrejinha Nossa Senhora de Fátima, em 1957, em Brasília, onde criou dois módulos, ambos sobre fundo azul de tonalidades diferentes e contornados por um friso branco, reforçando a idéia do azulejo como módulo, uma estrela de Belém na cor preta e uma pomba branca, posicionada para baixo. A pomba além de significar 0 Espírito Santo, faz alusão ao plano piloto de Brasília.

Seu primeiro contato com azulejo foi quando começou a trabalhar com Oscar Niemeyer, aprendeu experimentando, errando, aprimorando o olho. Um dos primeiros trabalhos foi o painel para o hospital da Lagoa em 1955, no Rio de Janeiro. "Athos compreende o azulejo como módulo, como elemento construtivo de espaço arquitetônico, com sua área individual, com sua matéria própria, com sua luz e superfície, como regra e como jogo. Aqui Athos Bulcão estabelece uma derramagem da liberdade, como potencialidade de criação" (HERKENHOFF, 2004).

Segundo Cabral (2005) Athos vai trabalhando de acordo com o local, o que tem que apresentar: se para criança, se apenas para ser visto. Por exemplo, ao compor o painel como uma das divisórias da creche do Sarinha, em Brasília, por onde não passa nem cabeça, nem perna de criança, evitando acidentes, observamos o enorme cuidado do artista. Em relação à escolha de temas, Cabral revela que a parede do Palácio do Jaburu lembra o bisturi do médico,
116. Azulejos residência Celso Kaufman. Arq. Elvin Dubugras. Brasília, 1984.

Fonte: ATHOS, 2000,p.184

117. Esquema de composição do painel de azulejo para residência Aloysio Campos da Paz. Acervo de Haroldo Pinheiro

118. Capela de N. S. de Fátima. Revestimento externo de azulejos de Athos Bulcão. Arq. Oscar Niemeyer. Fonte: Acrópole, n²56/257, 1960, p.103.

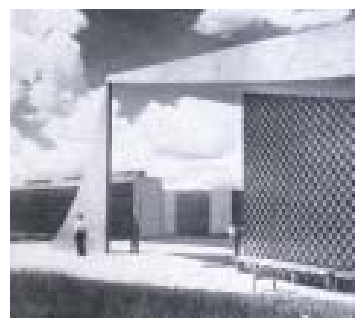


119. Painel de azulejos Hospital Sulamérica (Hospital da Lagoa). Arq. Oscar Niemeyer e Hélio Uchoa. Rio de Janeiro, 1955. Fonte: Módulo, Rio de Janeiro, ago. de 1959, v. 3, n. 14, p. 15.

120. Detalhe dos azulejos Hospital Fonte: ATHOS, 2001, p.57.
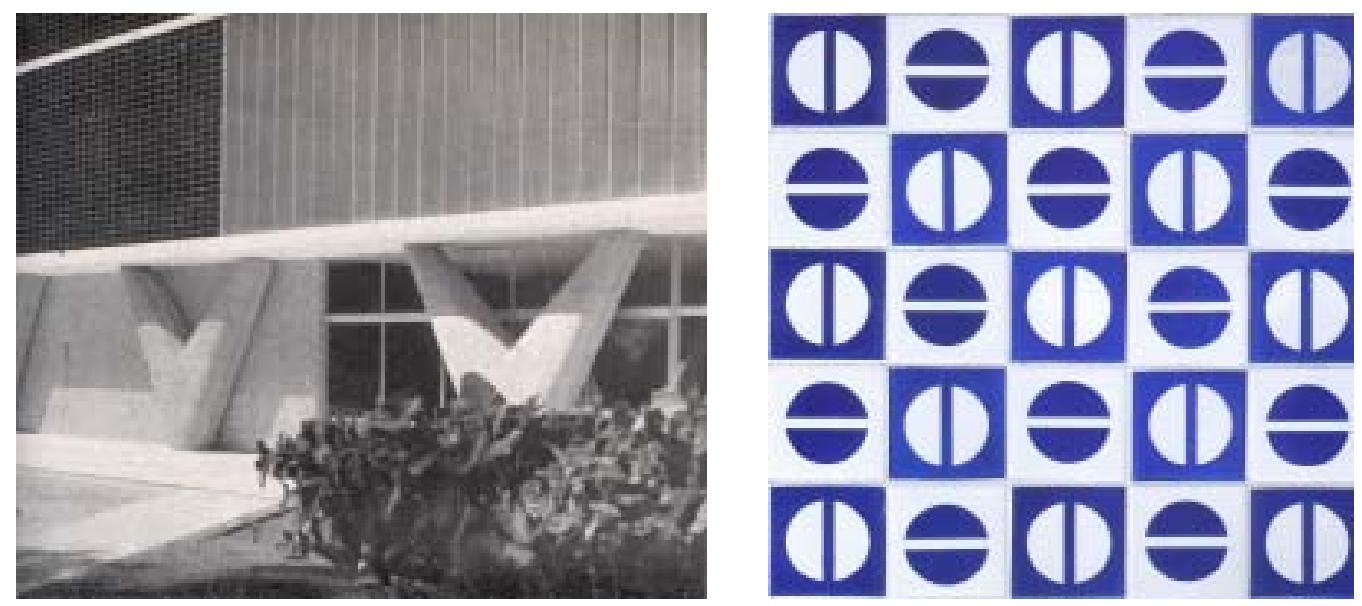

pois na época da criação deste trabalho Athos estava operado, o que demostra que ele tem um inteligente e bom senso de humor.

No projeto dos painéis do Sambódromo, no Rio de Janeiro, Athos conseguiu dois resultados bem diferentes: coordenou a montagem de um deles e o outro, deixou livre para os operários montarem. Os dois painéis possuem movimentos ritmados e incessantes, conseguidos com um desenho - apenas 0 traço de 1/4 de círculo em três diferentes operações: repetição, inversão e espelhamento, e com outro módulo, o azulejo branco liso, sem desenho.

Na composição, o círculo nunca se fecha, o que resultou em várias interpretações.

121. Painel em relevo de mármore e granito. Palácio do Jaburu. Arq. Oscar Niemeyer. Brasília,1975 Fonte: ATHOS, 2001, p.148.

122. E 123. Painéis de azulejos. Sambódromo. Arq. Oscar Niemeyer. Rio de Janeiro, 1983. Fonte: ATHOS 2001, p.178 e 177.
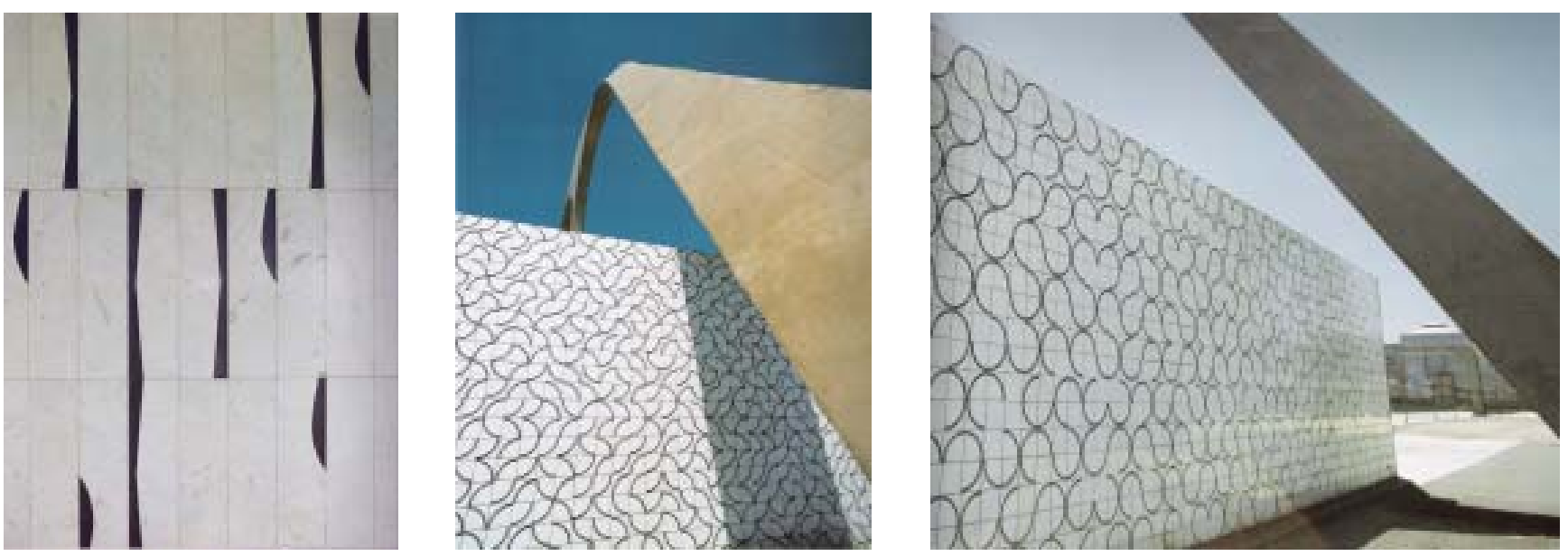


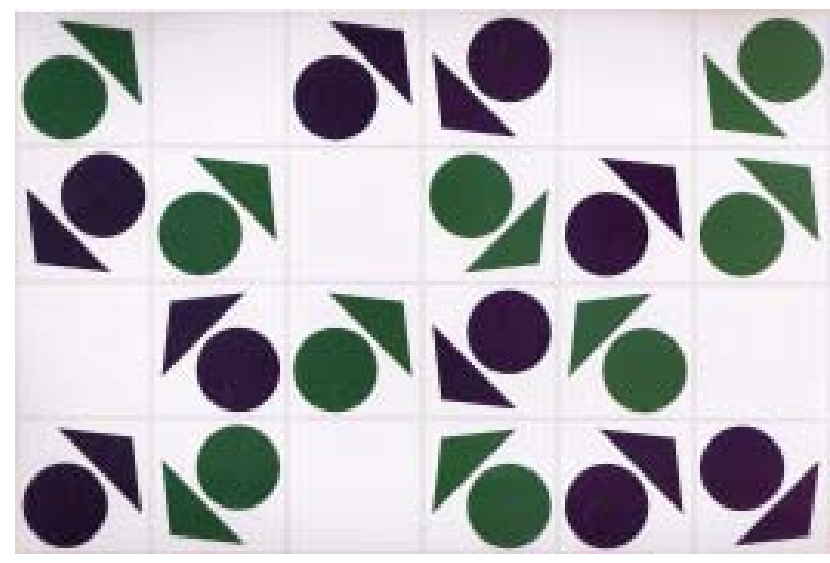

pelos operários é mais caótico, mas nem por isso, menos interessante que o painel composto pelo artista: duas linhas curvas formam nádegas, seios, copos e torsos que dialogam tanto com o símbolo do Sambódromo, criado por Niemeyer (duas nádegas), quanto com o próprio desfile do carnaval. O que se apreende do painel é a evolução dos sambistas, a multidão em movimento, 0 volteio das baianas, a apoteose da dança e do corpo, isto é, capta-se ou revela- se toda a sensualidade e erotismo do desfile.

Além dos motivos geométricos, retas, curvas, semicírculos, mais freqüentes na temática do artista, existem alguns poucos motivos que entrariam em um figurativo estilizado, como é o caso dos azulejos do Clube do Congresso. O desenho lembra um bonequinho estilizado como um logotipo. A colocação do módulo é aleatória, não tem posição determinada, o bonequinho aparece em diversas posições: de um lado, de outro, em pé ou de cabeça para baixo, brincando com a intenção de parecer um logotipo. O jogo também aparece, quando se usam módulos invertidos, isto é, positivo numa parede e negativo na outra.

Outro exemplo de figurativo estilizado são os azulejos cujo desenho foi composto por um círculo e um triângulo, criados para a casa da Valéria Cabral. Segundo Cabral (2005), o próprio Athos diz que o painel está em ebulição, pois Valéria é uma pessoa que está em eterno movimento. O agrupamento dos azulejos, a cada quatro, como habitualmente ele trabalha, pode formar palhaços ou pintinhos, dependendo de como sejam observados, mas não foi intencional, o principal era transmitir a sensação de movimento.

Athos diz que, se alguém não nasce com paixão pela cor, não adianta estudar. Considerase relativamente bom desenhista, mas o que gosta mesmo é da cor. Com Portinari aprendeu importantes conceitos sobre desenho e cor, mas é autodidata nos segredos da invenção de novas
124. Desenho dos azulejos da residência Valéria Cabral. Brasília,2001. Fonte: Calendário 2005. Fundação Athos Bulcão.

125. Painel de azulejos. Fundação Getúlio Vargas, Rio de Janeiro, 1962. Arq. Oscar Niemeyer. Fonte: ATHOS, 2001 
tonalidades. Antes de pintar, planeja as cores que vai usar e raramente muda sua escolha. Quando criança freqüentava o antigo carnaval do Rio de Janeiro, o que contribuiu para marcar sua visão estética. Suas cores têm a vibração da alegria da festa popular brasileira, como analisa Francisco (2001); em tom baixo, não são fortes nem exageradas, apenas paulatinamente, se percebem diversificadas, contrastantes e harmônicas (HERKENHOFF, 2004).

O artista faz 0 desenho, olha, pinta na cartolina com guache e corta os quadrados (módulos) e começa a brincadeira, a arrumá-los em diversas posições, sempre no esquema de 4 $x 4$ (jogo de quadro), freqüentemente em combinações do verde-azul e amarelo-laranja (CABRAL, 2005).

Geralmente, faz composições de módulos que apresentem várias possibilidades. Nos painéis, usa de um a quatro módulos diferentes e um número pequeno de cores (no máximo cinco), sendo muito comum a presença de somente duas, dentre elas o fundo branco do azulejo (base esmaltada). Trabalha também com negativo e positivo do mesmo módulo (desenho) como no painel do Hospital da Lagoa ou usa dois módulos e duas cores, como no painel da Fundação Getúlio Vargas, em 1962, e muitas vezes usa o azulejo liso sem desenho, como um módulo.

Nos hospitais da rede Sarah Kubitschek, obras realizadas em parcerias com Lelé, Athos fez genial uso da cor, em função do bem estar dos pacientes: substituiu os brancos frios, comuns aos hospitais, por cores diferentes, alegres, compondo ambientes cheios de vibração e calor.

\section{Execução e instalação dos painéis de azulejos de Athos Bulcão}

A execução artesanal dos azulejos de Athos Bulcão, há aproximadamente dez anos ${ }^{17}$, é atribuída a um artesão do Rio de Janeiro. Depois de definido o motivo, Athos faz o desenho que

${ }^{17}$ Artesão carioca em conversa por telefone com a autora. geralmente, é repassado para o computador, por um assistente, utlizando-se do programa Corel Draw. Posteriormente, é enviado via Internet, juntamente com as indicações das cores e do tamanho do azulejo para o ateliê no Rio de Janeiro. A princípio esses desenhos eram enviados pelo correio e eram executados em ploters, as cores indicadas através de uma paleta de cores que consistia numa amostra da cor (que podia ser um quadrado colorido serigrafado no azulejo e queimado) e a sua referência (por exemplo: vermelho 21).

No ateliê do Rio são feitos os fotolitos, as telas, a impressão em serigrafia e a queima das amostras que são enviadas para Athos, em Brasília. Ele então escolhe, modifica e aprova as 
amostras. Depois de aprovado, o azulejo é todo executado no ateliê no Rio de Janeiro. $\mathrm{O}$ artesão se encarrega de comprar o melhor azulejo do mercado, isto é, o que oferecer melhor qualidade na época da compra.

Normalmente, a pintura dos azulejos é em serigrafia, às vezes um fundo é aerografado como no azulejo do anexo do Teatro Municipal do Rio de Janeiro. A queima é feita em um forno contínuo de 25 metros, a terceira queima atinge uns 1020 graus. 0 processo é sempre de biqueima ou/e terceira queima. Dependendo da pintura e da queima as peças ficam com um pequeno relevo na área da figura ou do motivo pintado. A tinta usada é a de terceira queima, mas se o painel vai ficar externo, exposto ao sol e a chuva usa-se tinta para piso.

O período compreendido entre a execução de um projeto do desenho recebido no atelier até a entrega das peças é de aproximadamente 30 a 40 dias. Às vezes um azulejo demanda trabalho maior, como foi o caso do azulejo na cor bege, para o Teatro Municipal do Rio de Janeiro.

Bulcão criou um método de composição onde os operários fazem a colocação dos azulejos livremente. Esse sistema foi utilizado pela primeira vez em 1966, na Escola Classe da 408 Norte, projeto de Milton Ramos. A partir daí, este método foi empregado, várias vezes, como por exemplo, no painel de azulejos do Congresso Nacional, em 1971: com 1.200 m²,é composto por três padrões em azul e branco e outro totalmente branco, o que cria o "principio de composição" , formando um intenso movimento, acentuado pela variedade de posições que se multiplicam na composição dos azulejos no painel (TELLES, 1997).

Com desprendimento e genialidade, o artista cria o desenho dos módulos, manda estampar em azulejos, escolhe as cores e às vezes deixa a aplicação dos azulejos a critério do operário encarregado, liberando-o de qualquer regra de combinação e encaixe.

"O procedimento do artista em relação à aplicação dos módulos na parede, guia-se como se vê, antes pelo desordenamento premeditado do conjunto do que por um resultado

126. Azulejos. Acervo de Haroldo Pinheiro.

127. Azulejos em dois tons de amarelo. Acervo de Haroldo Pinheiro.

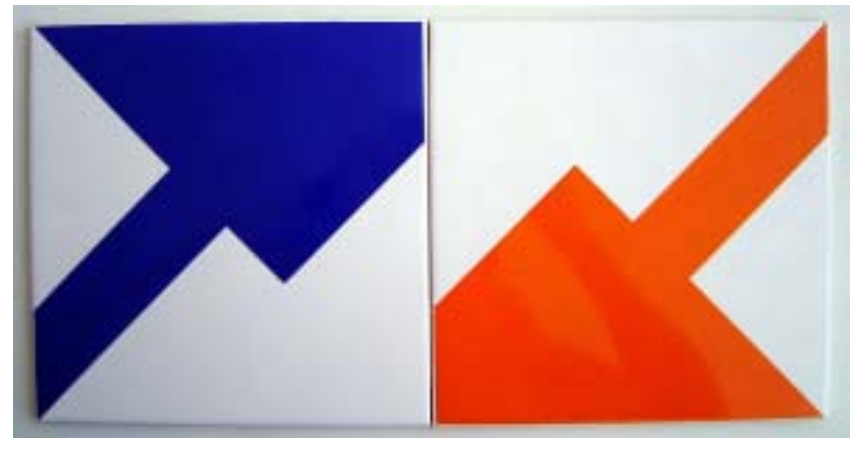


128. Painel de azulejos no Salão Verde da Câmara dos Deputados. Arq. Oscar Niemeyer Brasília, 1971.

129. Painel de azulejos Escola Classe SQN 407/408. Arq. Milton Ramos. Brasília, 1965 estável capaz de reiterar a geometria dos módulos que Ihe constitui. Diante de uma parede revestida por Athos Bulcão o olho, descentrado, erra. A parede torna-se um plano ativado, estilhaça-se aos olhos em velocidades que variam do vagar ao vertiginoso" (FARIAS, 2001, p.45).

No prédio do Interligis, em Brasília, Athos criou um painel que foi executado por um operário chamado Francisco Diniz. Quando soube que tinha que executar uma parede de azulejos sem projeto, sem desenho, ficou surpreso e nervoso. Já em cadeira de rodas, Athos foi à obra para orientá-lo na execução da parede, uma lona preta foi estendida no chão próxima à parede. Explicou-lhe então que existia uma lógica chamada proporção. Os desenhos dos azulejos eram semicírculos marrons e amarelos sobre fundo bege. Athos orientou Francisco no sentido de que os azulejos deveriam ser montados em conjunto de quatro, ou melhor, para cada três marrons um amarelo. Outras sugestões também foram passadas: evitar repetições e não fechar os círculos. Sobre aquela lona preta, Francisco montou o que se tornaria uma obra, sendo advertido pelo artista quando havia grande concentração de uma só cor: "Aqui tá muito marrom" (MACIEL, 2005)

No entanto, nem sempre Athos deixava o operário livre na montagem da obra. Isso só era possível no jogo aleatório dos azulejos. Segundo ainda Maciel, Athos acha que o operário é livre para fazer uma montagem, já que não tendo cursado escola de desenho e o ideal seria que a montagem fosse feita por uma criança, devendo o resultado final ser uma "coisa simples".

Os jogos visuais de Athos são perturbadores, no entanto, possuem uma regra muito simples. No painel da Escola Classe 407/408 Norte, por exemplo, o primeiro painel que foi realizado com a participação ativa dos operários, o padrão modular é formado por três azulejos de 15 x 15

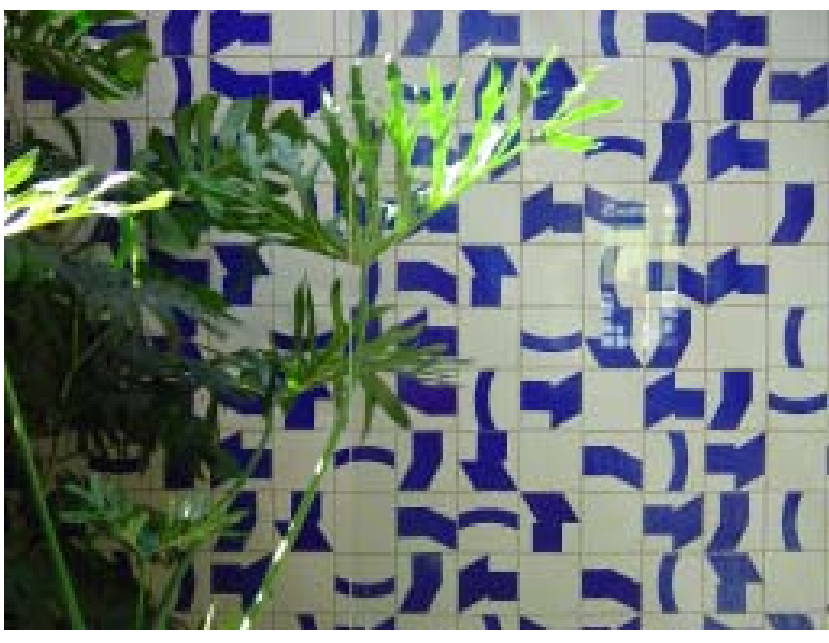

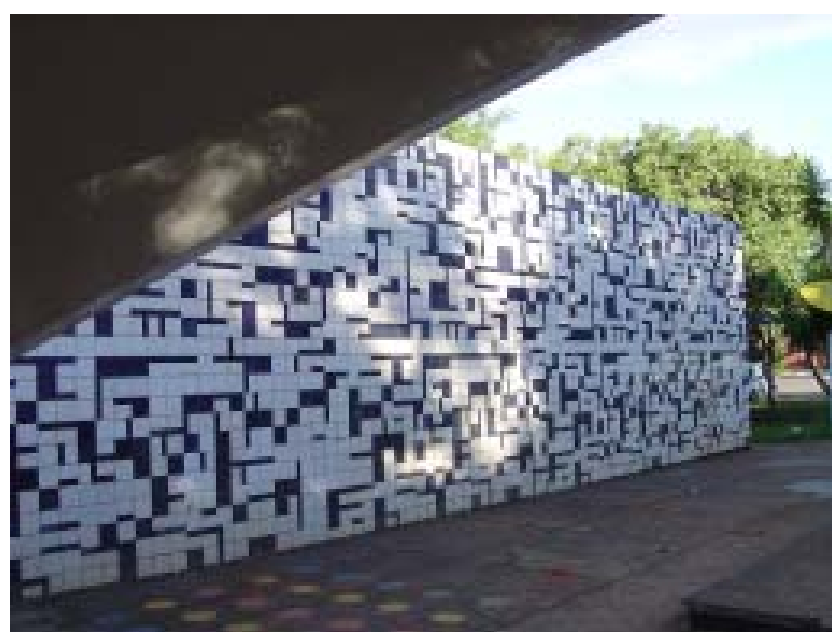

azulejo na arquitetura brasileira: os painéis de athos bulcão 

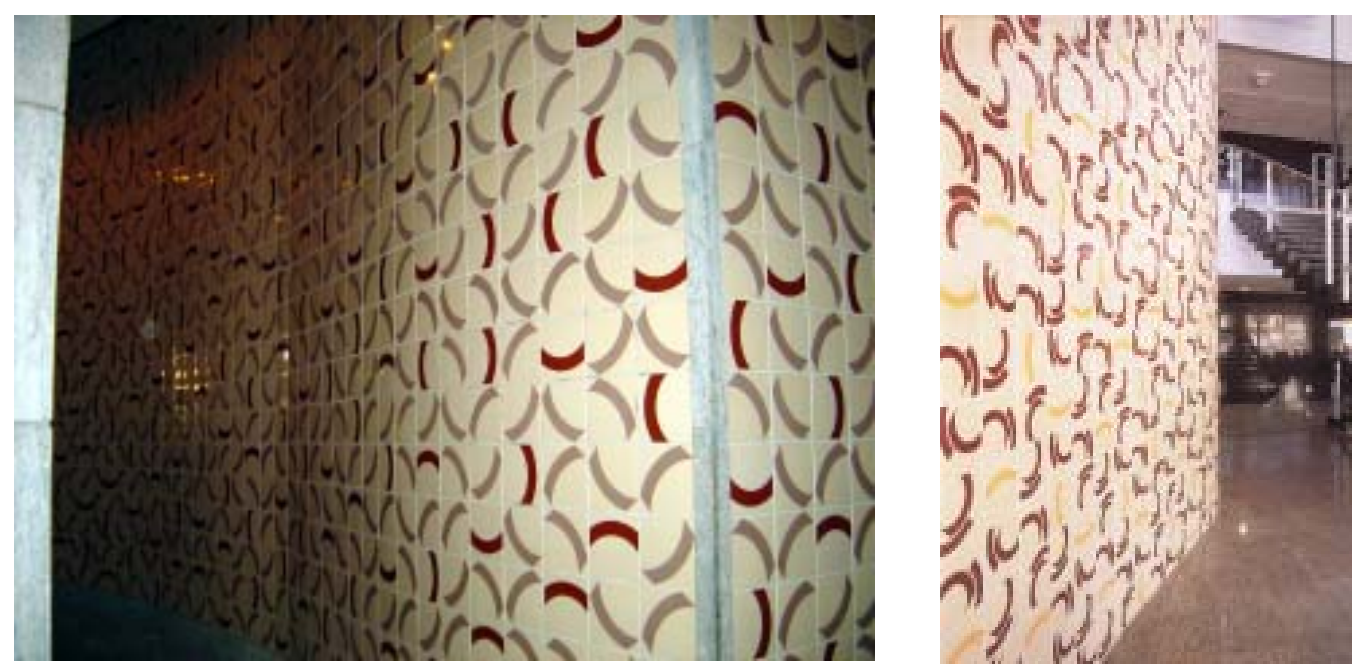

130. Painel de azulejos. Teatro Municipal. Rio de Janeiro.

131. Painel de azulejo. Edifício sede da Interlegis.

Arq. Luis Antônio Reis. Brasilia, 2001 Fonte: ATHOS, 2001, p.299

cm: um preto, um branco e um com 2/3 da superfície em branco e 1/3 em preto. Cada módulo se junta a outro, formando um todo aleatório, de ritmo cortado, onde é impossível entender sua seqüência rapidamente.

Na colocação dos azulejos, o mestre de obras sempre pergunta: Cadê o projeto? E como resposta, recebe a ordem para que ele próprio faça a composição no chão: "Olha tem branco em linha, não pode (quer dizer que não pode ter uma linha branca na composição). Tem verde demais, ou tem concentração de uma cor só. Tente de novo, de outra forma, cuidado para não ficar muito pesado, de uma cor só e não ter branco em linha" (CABRAL, 2005).

\section{Afinidades contemporâneas}

Athos Bulcão é um artista que ajudou e incentivou a formação de nova geração de artistas em Brasília. Sempre abriu seu ateliê e sua casa para discussões sobre as artes. Houve vários auxiliares que trabalharam em seu ateliê, como por exemplo, o arquiteto Haroldo Pinheiro ${ }^{19} \mathrm{e}$ Walter Menon ${ }^{20}$, dentre outros. Em relação ao seu trabalho de azulejos, percebe-se que 0 artista deixou sua marca em uma nova geração. Podem-se pontuar alguns seguidores, artistas e arquitetos que, de certa forma, se inspiram ou se remetem ao tipo de trabalho feito pelo Athos.

Analisando os painéis de azulejos de Petrônio Cunha, artista plástico e arquiteto formado pela Universidade Federal de Pernambuco, pudemos perceber alguma semelhança estética com os painéis de azulejos de Athos Bulcão, pois usa os mesmos princípios de composição. Atualmente, exerce cargo de arquiteto da Prefeitura de Olinda e participa do projeto "Arte em toda parte", também da cidade de Olinda. Foi aluno de Delfim Amorim no curso de arquitetura da UFPE, onde 
${ }^{19}$ Ver entrevista no apêndice 1.

${ }^{20}$ Ralf Gehre artista plástico em conversa pelo telefone com a autora.

132. Painel de azulejos de Petrônio Cunha. Agência da Caixa Econômica Federal, Recife. Arq.: Carlos Fernando Pontual Gerônimo da Cunha Lima.

133. Painel de azulejos de Petrônio Cunha. Tribunal de Contas da União, Recife, 1995. Arq.: Antônio Amaral, Clara Charifker Ana Amélia Oliveira e Tânia Schwambach.

134.Painel de azulejos de Petrônio Cunha. Associação Brasil América, Recife 1997. entrou em contato com desenho de azulejos, uma vez que o mestre exigia como exercício da disciplina, a criação e desenhos de azulejos. Em 1969, foi a Brasília fazer um estágio com Athos Bulcão e participou da execução de um letreiro para um edifício.

Petrônio é um admirador de Olinda, para onde se mudou e começou a trabalhar com a imagem da cidade. Trabalhou muito com o modular e com o gráfico, com recortes, folders, cartazes. Tinha sempre em mente um desenho que podia ser ampliado. Devido a sua formação, a escala arquitetônica está sempre presente no seu pensamento, como um pano de fundo. À medida que desenha, vai intuindo uma escala maior. Muitas vezes, na sua relação com o desenho, tem a arquitetura como objetivo (CUNHA, 2004).

No muro da agência da Caixa Econômica Federal, na Avenida Dantas Barreto, no centro do Recife, Petrônio usou dez ou doze padrões diferentes, desenvolvendo uma linguagem visual. Os azulejos foram pintados em azul com fundo branco. Nesse projeto, trabalhou com os arquitetos Carlos Fernando Pontual e
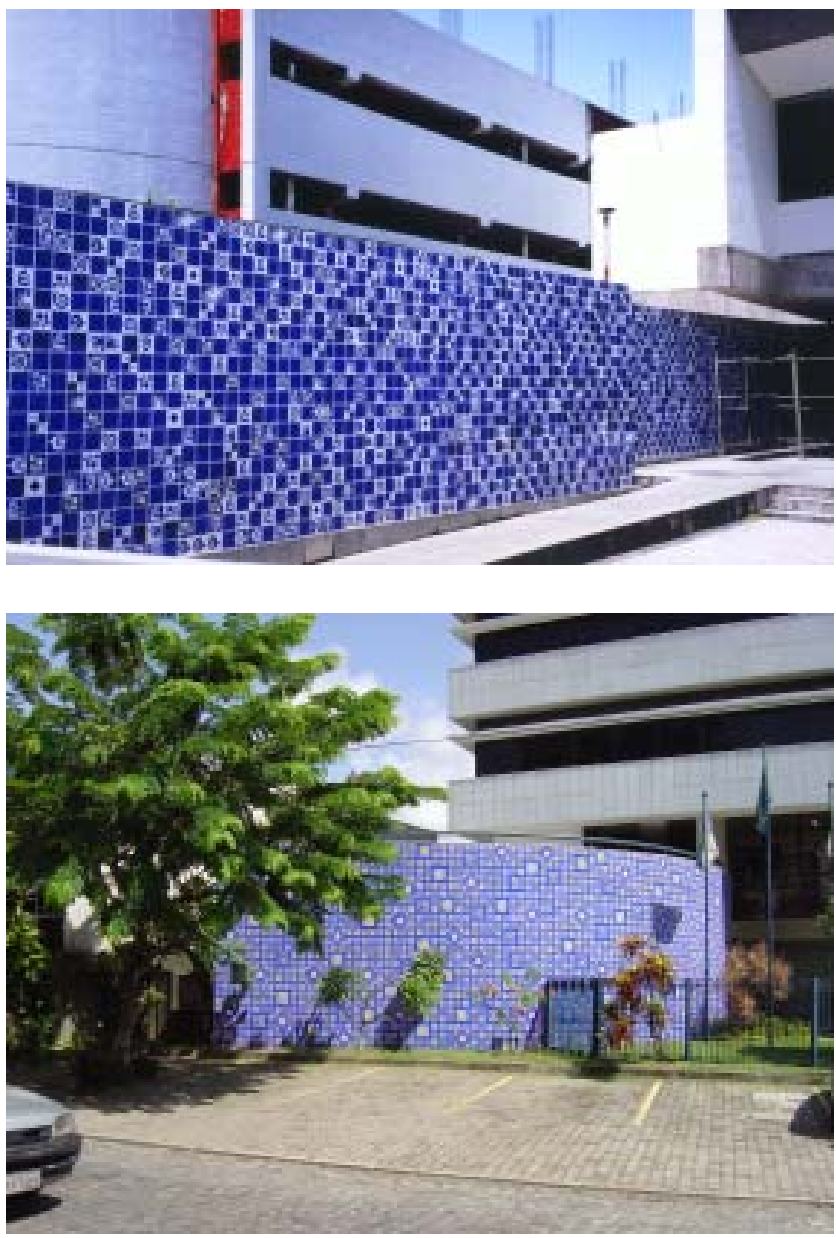

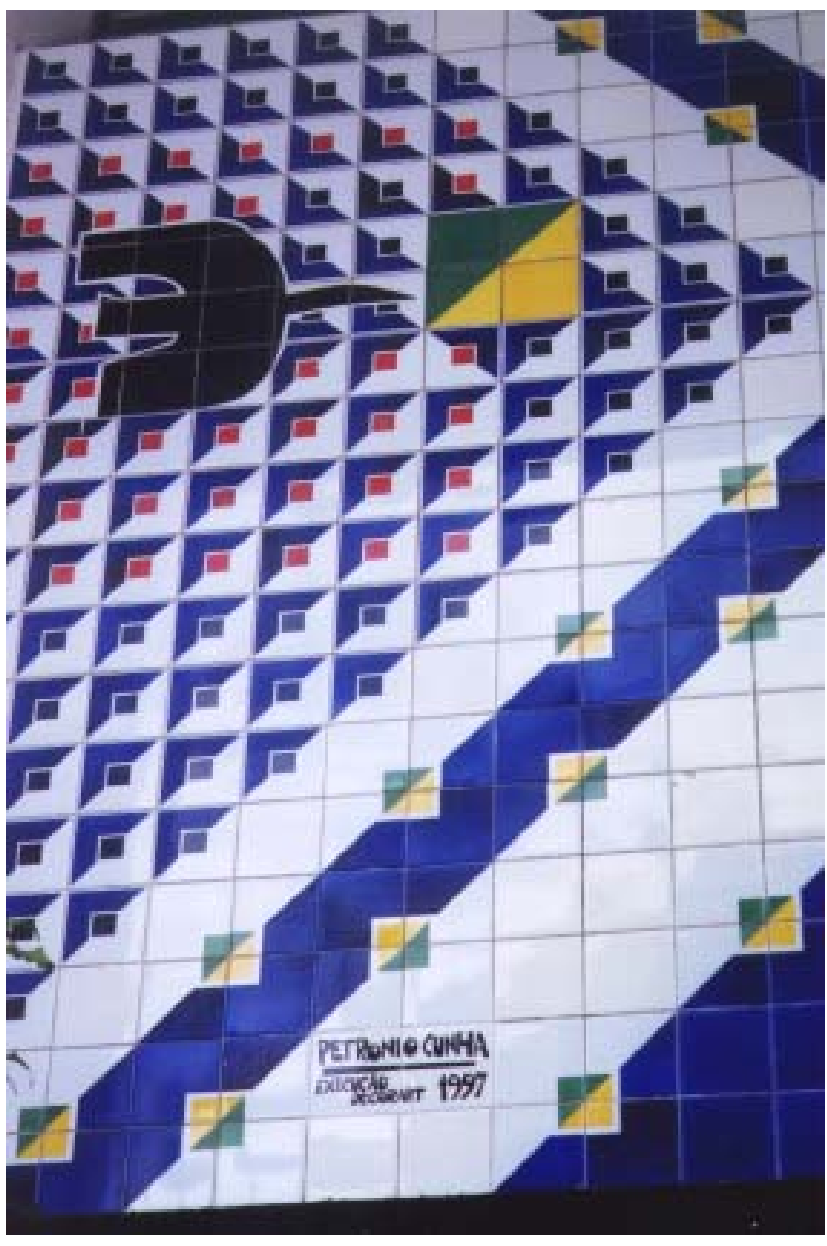


Gerônimo da Cunha Lima. O muro de azulejos externo continua na parede interna da agência, sendo separado apenas por uma parede de vidro. Hoje o vidro foi escurecido, porém, no projeto original visualizava-se a continuidade do muro. Esse trabalho tem uma linguagem que lembra os trabalhos de Athos Bulcão, como o uso de duas cores, a alusão ao carnaval com os desenhos que parecem serpentinas e confetes e a disposição aleatória.

Já no projeto que realizou no Tribunal de Contas, o desenho dos azulejos é sofisticado, moderno e simples, tendo conseguido um feliz resultado. Além da cor azul sobre branco, que considera tradicional em trabalhos com azulejos, usou também o amarelo sobre fundo branco. A encomenda inicial era para revestir uma parede curvilínea da entrada do prédio. Petrônio propôs e os arquitetos aceitaram revestir também a torre que fica na parte de cima e atrás do prédio. Para essa composição houve um estudo matemático específico. A composição é feita com elementos pequenos, onde cada azulejo forma um desenho, e elementos grandes que são formados com a junção de quatro azulejos (2x2). 0 artista definiu um princípio de aplicação onde cada módulo de 10x10, por exemplo, deveria conter os três elementos grandes e os pequenos, mas não estabeleceu a posição dos elementos. Essa disposição ficou a cargo do operário ou mestre de obra que instalou os azulejos, resultando, assim, numa composição aleatória, princípio que nos remete aos projetos de Athos Bulcão.

Os projetos com azulejos que Petrônio desenvolveu foram executados pela Decorat, ateliê que executa trabalhos em cerâmica, tanto artísticos como azulejos fora de linha e encomendas especiais. Petrônio cria o projeto, escolhe as cores e faz o desenho. A Decorart passa os desenhos para a tela para serem serigrafados nos azulejos e queimados numa terceira queima. Geralmente as pinturas são feitas por serigrafia. Quando o motivo é grande demais para ser executado em serigrafia usa-se, então, o processo de máscara e pintura com pistola, como foi 0 caso de alguns desenhos do projeto da fachada do prédio da ABA - Associação Brasil América.

Petrônio tem um caderno onde está sempre desenhando coisas, técnica comum entre artistas. Muitas vezes, recorre a ele, procurando inspiração para algum projeto. Nada é por acaso, nenhum desenho sai do nada, sua inspiração vem do seu próprio universo, dos seus rabiscos e rascunhos. O processo criativo de Petrônio tem algo do método construtivo. 
Athos Bulcão não deixa especificamente um herdeiro, pelo que foi analisado, nota-se que ele é um artista influente, espalhou sementes. Pode-se dizer que existem artistas plásticos que foram e são influenciados por ele, na atuação profissional. 


\section{consideraçães finais}

Nesta pesquisa o objeto azulejo foi abordado como peça cerâmica isolada e também integrada aos conjuntos arquitetônicos, para explicar questões ligadas à sua origem, evolução histórica e função decorativa. Foi objetivo da pesquisa enquadrar o azulejo no conjunto das manifestações artísticas do país e mostrar sua importância e contribuição para a formação de uma estética nacional, tendo como estudo de caso a obra azulejar do artista plástico Athos Bulcão.

A tradição, o gosto e a moda de usar azulejos como revestimento de parede no Brasil veio de Portugal, assim como seus exemplares e modo de fabricação são heranças portuguesas. Esse gosto lusitano infiltrou-se na cultura brasileira, que por sua vez, captou as características físicas e estéticas do material e expandiu sua utilização para as fachadas de casas, sobrados e igrejas.

Podem-se identificar alguns motivos diferentes para a utilização de azulejos em fachadas, sendo a característica física do azulejo uma das mais fortes. O Brasil possui cidades de climas tropicais, principalmente as litorâneas e margeadas por rios, onde a ocorrência de chuvas e umidade é muito freqüente e abundante. Sendo refratário à ação do sol o azulejo impede a corrosão da umidade nas paredes, torna as residências mais frescas, é de fácil manutenção e apesar de ser um produto caro, seu uso é compensado pela ausência de custo na conservação e pela alta durabilidade.

Através da evolução do uso do azulejo, pode-se contar uma parte da história do Brasil, pois as diversas fases de dominação e colonização no Brasil podem ser notadas pela historiografia do azulejo, que foi diferenciada durante a colonização portuguesa, o domínio holandês, depois da abertura dos portos. Também acompanhou e retratou os movimentos artísticos e arquitetônicos brasileiros como o neocolonial, o moderno e o contemporâneo.

Outro fator que aumenta a aceitação na retomada e recuperação do uso de azulejos nas paredes externas é o estético, pois permite várias possibilidades de composições, cores e modelos, adaptando-se aos diversos estilos arquitetônicos e artísticos.

Em alguns períodos, o azulejo usado como material de construção ligado à arquitetura foi menos usado, em detrimento de outros materiais, talvez, influenciados por questão de gosto e 
tendências que variam conforme as épocas. Pode-se dizer que o fator econômico não tenha sido a causa dessa escolha: até mesmo quando trazidos de navios de Portugal, no período Colonial, foram utilizados em abundância.

O trabalho em conjunto, a integração de artistas plásticos e arquitetos, no campo da azulejaria brasileira, mostra, ao longo dos anos, excelentes resultados. Algumas obras mais desconhecidas, outras mais divulgadas fazem parte de marcos da a arquitetura, como é o caso dos painéis do prédio do MES, ou da igreja da Pampulha. Essa união entre artistas e arquitetos, no entanto, às vezes, gerou certa polêmica, devido à hierarquia e ao grau de importância que se deu às diferenças profissionais.

Pode-se dizer que o uso de painéis de azulejos integrados à arquitetura valoriza, destaca e acrescenta soluções à obra arquitetônica, até mesmo quando se trata de algum problema funcional e foi resultado de parcerias onde 0 artista plástico participa desde o início do projeto, pensando juntamente com 0 arquiteto nas respostas para a obra de arte e a arquitetura.

O que se nota é que essa colaboração, que resultou em tão bons trabalhos e que integrou movimentos artísticos e arquitetônicos vem desaparecendo. Atualmente, poucos profissionais utilizam o azulejo como suporte para suas obras, apesar da confirmação desse revestimento cerâmico como solução ideal e adequada para certos ambientes.

As obras relevantes de revestimento azulejar ainda estão sendo executadas por processos de produção artesanal ou semi-industrial. O processo industrial tradicional não está sendo adequadamente utilizado, isto é, não há a participação importante da indústria cerâmica brasileira nesses trabalhos, tanto no presente como no passado, revelando falta de integração entre produtores, arquitetos, artistas e designers.

Dentre os revestimentos cerâmicos existentes no mercado, o azulejo pelas suas características especificas, pode e deve ser considerado como opção de uso adequado em fachadas, desde que tomados os devidos cuidados. A ausência de especificações ou especificações equivocadas provoca sérios riscos e problemas, na maioria das vezes, indevidamente atribuídos ao produto. Tanto consumidores como pessoal técnico especializado desconhecem ou não valorizam essa aplicabilidade do azulejo, sobretudo em cidades litorâneas ou margeadas por rios. 
Seria interessante lembrar às empresas produtoras que o azulejo faz parte da memória arquitetônica nacional e que com 0 atual desenvolvimento científico e tecnológico, elas devem investir na produção de design de azulejos para fachadas.

Da obra do artista plástico Athos Bulcão foram enfocados apenas os painéis de azulejos, objetivo desta pesquisa, no entanto, sua obra completa é forte objeto de estudo. Percebe-se que ainda há muito a aprender com sua obra, que merece a atenção dos que se interessam pelo estudo das artes plásticas. Costa (1998) enfatiza que algumas características do artista como 0 uso de variadas técnicas e suportes, o rigor das composições, o compromisso leve e explícito com propostas modernistas, a preocupação com a síntese das artes, a trajetória elegante e sutilmente irreverente faz dele um ator ímpar no cenário da arte contemporânea.

Athos Bulcão se destaca dentro de questões de integração da arte à arquitetura, como um profissional que soube pensar a arte e a arquitetura, valorizando os espaços, criando uma identidade própria, usando a arte em função do espaço e dos usuários. Atento às influências do contexto artístico no Brasil, o artista optou por soluções geométricas como temas de seus painéis de azulejos comprometidos com a proposta arquitetônica do edifício; ele trabalha em função da arquitetura, destacando-a e valorizando-a.

Os azulejos de Athos Bulcão carregam visão histórica desde a época colonial, passam por marcos da arquitetura brasileira como Pampulha e o prédio do MES, também absorvem a geometria da arte concreta para finalmente criar composições próprias, jogos de ritmos e cores que, ao mesmo tempo, perturbam e fascinam o olhar do transeunte, da população.

Por opção, não assina seus painéis de azulejo, pois quer que sua obra se confunda com a paisagem da cidade, ou que se integre totalmente ao edifício onde está inserida. Com apurado senso estético, educa a população que não tem outro contato com a arte, senão o de suas obras públicas. Dedica a sua obra ao bem estar do povo, fato que o qualifica e o diferencia de outros artistas.

Nos azulejos de Athos Bulcão está fortemente presente a questão estética, a questão funcional e o bem estar das pessoas. O que de certa maneira, constrói um diálogo ou se relaciona com o uso dos azulejos nas fachadas no período colonial brasileiro, quando o azulejo era usado tanto para embelezar as fachadas como para protegê-las das chuvas deixando também as casas mais agradáveis no calor. O exemplo de Athos Bulcão e artistas influenciados ou não por ele 
pode ser uma fonte para a retomada do uso de azulejos nas fachadas, para que não se extinga essa forte tradição brasileira.

A escassez de trabalhos acadêmicos sobre 'azulejo' foi facilmente constatada, inclusive no que se refere à produção industrial brasileira; as publicações encontradas são artigos em revistas técnicas especializadas. Há poucos anos a produção brasileira se concentrava no Estado de Santa Catarina, principalmente próximo à cidade de Criciúma, no entanto, nas últimas décadas, o pólo de Santa Gertrudes, no interior paulista, em rápido crescimento, vem se destacando no cenário nacional como produtor importante e de alta qualidade. O Estado de São Paulo possui, atualmente, um total de sessenta indústrias de revestimento cerâmico, sendo que quarenta e três pertencem ao pólo de Santa Gertrudes.

Finalmente, como últimas considerações, gostaríamos de acrescentar que, para a realização desta pesquisa estudamos alguns assuntos que extrapolariam o âmbito de um mestrado, contudo, são apontados caminhos que servem como sugestões para futuros trabalhos. $O$ uso do azulejo na arquitetura constrói vários diálogos possíveis. Analisar as relações e diálogos entre 0 uso do azulejo nas criações do arquiteto Delfim Amorim e dos artistas plásticos Athos Bulcão e Petrônio Cunha, foi uma das idéias que surgiram no decorrer da pesquisa e que se transforma numa sugestão para estudos posteriores. 


\section{referências}

ALCÂNTARA, Dora. (Org.). Azulejos na cultura luso-brasileira. Rio de Janeiro: IPHAN, 1997. Azulejos portugueses em São Luís do Maranhão. Rio de Janeiro: Fontana - Fundação Luiz La Saigne, 1980.

Azulejo documento de nossa cultura. In: MARIA, Cristina Vereza Lodi Dias. (Org.). Patrimônio azulejar brasileiro: aspectos históricos e de conservação. Brasília: Ministério da Cultura, 2001. p.27-73.

AMARAL, Aracy. (Org.). Quatro mestres escultores brasileiros contemporâneos arte e espaço urbano: quinze propostas. Brasília: Fundação Athos Bulcão, 1996.

AMARAL, Aracy A. (Coord.). Projeto construtivo na arte: 1950-1962. Rio de Janeiro: Museu de Arte Moderna; São Paulo: Pinacoteca do Estado, 1977.

AMORIM, Luiz. Arquitetura. In: ROSEMBERG, André. Pernambuco 5 décadas de arte. Recife: Quadro Publicidade e Design, 2003. p.58-125.

Delfim Amorim construtor de uma linguagem síntese. AU, São Paulo, ano 5, n.24, p.9497, jun./jul. 1989.

ANELLI, Renato. Rino Levi, arquitetura e cidade 1901-1965. São Paulo: Romano Guerra, 2001.

AQUINO, Flávio. Azulejos e vitral para Brasília. Modulo, Rio de Janeiro, v.2, n.C10, p.26-29, ago. 1958.

1955.

Duas fotomontagens de Athos Bulcão. Modulo, Rio de Janeiro, v.1, n.3, p.56-57, dez.

ARAÚJO, Amandio; ROMACHELLI, João C.; MARTINS , Manoel. Análise crítica do setor de revestimentos cerâmicos no Brasil parte I; histórico recente. Cerâmica Industrial, São Paulo, v.6, n.4, p.29-34, jul./ago. 2001.

ATHOS Bulcão. São Paulo: Fundação Athos Bulcão, 2001.

ATHOS Bulcão 80 anos. São Paulo: Pinacoteca do Estado; Fundação Athos Bulcão, 1998. Catálogo.

ATHOS Bulcão uma trajetória plural. Curadoria: Fernando Cocchiarale. Coordenação: Cláudio Teles. Produção: Valéria Cabral. Vídeo: Malu de Martino. Realização: Centro Cultural Banco do 
Brasil. Organização: Fundação Athos Bulcão. Brasília: Fundação Athos Bulcão, 1998. 1 videocassete.

ATHOS Bulcão: construção \& poesia. Disponível em:<http://www.radiobras.gov.br/cultura/mat/ culturamat1618bulcao_0912.htm>. Acesso em: 10 jan. 2004.

BARATA, Mário. As condições do uso da azulejaria de revestimento externo no Brasil e em Portugal - relacionamento parcial com o clima de trópico, no primeiro país. In: Congresso Brasileiro de Tropicologia, 1, 1986, Recife. Anais...Recife: Fundaj, Massangana, 1987. p.178-183. Disponível em:<www.tropicologia.org.br/conferencil/1986condicoes_azulejaria.html>. Acesso em: 2 jun. 2005.

BARDI, Pedro Maria. Arte da cerâmica no Brasil. São Paulo: Banco Sudameris Brasil, 1980.

BARRETO, André. Athos Bulcão, 82 anos o mestre das cores. Disponível em:<http:// www.terra.com.br/istoegente/70/testemunha/>. Acesso em: 10 jan. 2004.

BERG, Egon Antonio T.; TAVARES, Maria Sampaio; GAMA, Sérgio Saldanha. Considerações sobre a utilização do azulejo no Brasil. Construção em São Paulo, São Paulo, ano 25, n.1296, p.37-38, dez. 1972.

BOSCHI, Anselmo. Uma análise do setor de revestimentos cerâmicos. Cerâmica Industrial, São Paulo, v.7, n.2, p.8-13, mar./abr. 2002.

BRAGA, Andréa da Costa; FALCÃO, Fernando A.R. Guia de urbanismo, arquitetura e arte de Brasília. Brasília: Fundação Athos Bulcão, [1997?].

BRAGA, Rubem. Cidade e a roça: crônicas. Ilustração de Athos Bulcão. Rio de Janeiro: José Olympio, 1957.

BRASÍLIA. Rio de Janeiro; Brasília: Alumbramento, 1986.

BRITO, Ronaldo. Neoconcretismo, vértice e ruptura do projeto construtivo brasileiro. Rio de Janeiro: FUNARTE; Instituto Nacional de Artes Plásticas, 1985.

BRUAND, Yves. Arquitetura contemporânea no Brasil. 4.ed. São Paulo: Perspectiva, 2002.

BULCAO, A. Athos Bulcão: construção e poesia. Brasília: Centro Cultural Banco do Brasil, 2002.

BULCÃO, A. Brasília da primeira hora: fragmentos. Módulo, Rio de Janeiro, n.89/90, p.104-107, jan./abr. 1986.

BULCÃO, A. Fotomontagens. Comentários de Fernando Cocchiarale. Revista do Patrimônio Histórico, Rio de Janeiro, n.27, p.314-325, 1998.

BUSTAMANTE, Gladstone Motta; BRESSIANI, José Carlos. A indústria cerâmica brasileira. Cerâmica Industrial, São Paulo, v.5, n.3, p.31-36, maio/jun. 2000. 
CABRAL, Eduardo. Eduardo Cabral: entrevista [abr. 2005]. Entrevistadora: Ingrid Moura Wanderley. Brasília.

CABRAL, Valéria. Valéria Cabral: entrevista [abr. 2005]. Entrevistadora: Ingrid Moura Wanderley. Brasília.

CALADO Rafael Salinas. Características do azulejo em Portugal. In: O REVESTIMENTO cerâmico na arquitetura em Portugal. Lisboa: Estar, 1998. p. 7-15.

CAMPOS, Maria Cristina André. Memória urbana - mural moderno em São Paulo. 2v. 2001. Dissertação (Mestrado) - Faculdade de Arquitetura e Urbanismo, Universidade de São Paulo, São Paulo, 2001.

CAMPOS, Paulo Mendes. Palavra escrita. Ilustração de Athos Bulcão. Rio de Janeiro: Hipocampo, 1951.

CARDOSO, Joaquim. Azulejos na arquitetura brasileira. Revista Cultura, Rio de Janeiro, n.1, p. 201-204, 1948.

CARIDADE, Marcelo Dias. Estratégias de produção das empresas de cerâmica para revestimento de Santa Gertrudes: estudo de caso. 232p. 2000. Dissertação (Mestrado) Universidade Federal de São Carlos, São Carlos, 2000.

CATALÃO, T.T. O Mosaicista Athos Bulcão. Disponível em:<gougon2.tripod.com/id26.html >. Acesso em: 10 jan. 2004.

CAVALCANTI, Caros. História das artes: curso elementar I. Pré história - Antigüidade. Rio de Janeiro: J.Ozon, 1963.

CAVALCANTI, Sylvia Tigre de Hollanda. O azulejo na arquitetura civil de Pernambuco, século XIX. São Paulo: Metalivros, 2002.

CENTRO CERÂMICO DO BRASIL. Disponível em: <www.ccb.org.br>. Acesso em: 12 jun. 2003.

CHAIMOVICH, Felipe. Cinqüenta 50. São Paulo: Museu de Arte Moderna de São Paulo. Ministério da Cultura, 2005. Catálogo.

CIRURGIA fotográfica. Habitat, São Paulo, n.17, p.60-61, jul./ago. 1954.

50 ANOS Bienal de São Paulo, 1951-2001: homenagem a Francisco Matarazzo Sobrinho. São Paulo: Fundação Bienal de São Paulo, 2001.

COCCHIARALE, Fernando. Fotomontagens - Athos Bulcão. Revista do Patrimônio Histórico e Artístico Nacional, Rio de Janeiro, n.27, p.314-325, 1998.

COCCHIARALE, Fernando. Athos Bulcão uma trajetória plural. Pesquisa de Clara Inneco e 
Paola Antony; versão para o inglês de Izabel Murat Burbridge; fotografias de Rui Faquini e Vicente de Mello. Rio de Janeiro: Centro Cultural Banco do Brasil, 1998. Catálogo.

O CONCEITO cerâmico. Mundo Cerâmico, São Paulo, ano 4, n.24-A, p.8-9, abr. 1996.

CORONA, Eduardo; LEMOS, Carlos Alberto Cerqueira. Dicionário da arquitetura brasileira. 2.ed. São Paulo: Art Show Books, 1989.

COSTA, Ana Beatriz de Paiva. Releitura na obra Athos Bulcão. 1998. 111p. Dissertação (Mestrado) -Universidade de Brasília, Brasília, 1998.

COSTA, Lúcio. Registro de uma vivência. São Paulo: Emprenta das Artes, 1995.

COSTA, Lúcio. In: KNOFF, Udo. Azulejos da Bahia. Rio de Janeiro, Livraria Kosmos, Salvador, Fundação Cultural do Estado da Bahia, 1986.

COSTA, Marcus de Lontra. Athos Bulcão sinfonias da modernidade. Módulo, Rio de Janeiro, n.95, p.32-37, 1987.

CUNHA, Érica Cristina. Projeto e execução de fachada com porcelanato. 193p. 2001. Dissertação (Mestrado) - Escola de Engenharia de São Carlos, Universidade de São Paulo, São Carlos, 2002. CD-ROM.

CUNHA, Petrônio. Petrônio Cunha: depoimento. [fev. 2004]. Entrevistadora: Ingrid Moura Wanderley. Recife.

DELFIM Amorim, arquiteto. Recife: Instituto de Arquitetos do Brasil; Departamento Pernambuco, 1981.

EGON, Antônio T.; BERG, Maria Sampaio Tavares; SALDANHADA GAMA, Sérgio. Considerações sobre a utilização do azulejo no Brasil. Construção em São Paulo, São Paulo, n.1296, p.37, 1972.

EM DOIS edifícios, museu combina o passado e o presente, de olho no futuro. Projeto Design, São Paulo, n.275, p.40- 55, jan. 2003. Número especial: Oscar Niemeyer e Brasil arquitetura: novo museu.

ESTRADA, Maria Helena. Uma inversão do olhar. Disponível em:<www.arcdesign.com.br/ed26/ matprinc26.htm>. Acesso em: 12 jun. 2003.

FARIAS, Agnaldo. Construtor de espaços. In: ATHOS Bulcão. São Paulo: Fundação Athos Bulcão, 2001. p.34-53.

FERRAZ, Ana Lucia Machado de Oliveira. Insigne presença: arte e arquitetura na integração dos painéis na obra de Rino Levi. 51p. 1998. Dissertação (Mestrado) - Escola de Engenharia de São Carlos, Universidade de São Paulo, São Carlos, 1998. 
FOTOMONTAGENS de Athos Bulcão. Brasil Arquitetura Contemporânea, Rio de Janeiro, n.5, p.56, 1955.

FRANCISCO, Severino. Habitante do silêncio. In: ATHOS Bulcão. São Paulo: Fundação Athos Bulcão, 2001. p.322-335.

FREIRE, Rita. Cerâmica: novos caminhos se insinuam. Design Belas Artes, São Paulo, ano 6, n.7, p.23-29, fev. 2000.

FREITAS, Grace. Módulos em expansão. Correio Braziliense, Brasília, 1997. In: Textos críticos selecionados, Brasília, Fundação Athos Bulcão.

GIEDION, Sigfried. 1956. In: MINDLIN, Henrique E. Arquitetura moderna no Brasil. Tradução de Paulo Pedreira. Rio de Janeiro: Aeroplano/IPHAN, 2000.

GOMES DA SILVA, Geraldo. Marcos da arquitetura moderna em Pernambuco. In: SEGAWA, Hugo. Arquiteturas no Brasillanos 80. São Paulo: Projeto, 1998. p.19-27.

GOODWIN, Philip Lippincott. Brazil builds: architecture new anad old, 1652-1942. Fotografia de G.E.Kidder Smith. New York: The Museum of Modern Art, 1943.

GORINI, Ana Paula Fontenelle; CORREA, Abidack Raposo. Cerâmica para revestimentos. Publicações BNDES, 1999. Disponível em:<http://www.bndes.gov.br/conhecimento/ resposta.asp?setorTema=Cer\%E2mico>. Acesso em: 24 set. 2003.

GULLAR, Ferreira. Etapas da arte contemporânea: do cubismo ao neoconcretismo. São Paulo: Nobel, 1985.

HERKENHOFF, Paulo. Apresentação da exposição individual pinturas, máscaras e objetos. Brasília: Espaço Capital; Rio de Janeiro: Galeria Saramenha, 1987.

Para ver melhor Athos Bulcão. Disponível em: <http://www.ocaixote.com.br/galeria1/

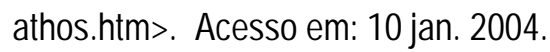

HUG, Alfans. Revendo Brasília. In: REVENDO Brasília. Fotos de Mário Cravo Neto et al. Brasília: Goethe Institut; Fundação Athos Bulcão, 1994. p.7-11.

ITAÚ CULTURAL. Enciclopédia de artes visuais. Disponível em: <http://www.itaucultural.org.br>. Acesso em: 5 jan. 2006.

KNOFF, Udo. Azulejos da Bahia. Rio de Janeiro: Kosmos; Salvador: Fundação Cultural do Estado da Bahia, 1986.

LEMOS, Carlos A.C. Azulejos decorados na modernidade arquitetônica brasileira. Revista do Patrimônio Histórico e Artístico Nacional, Rio de Janeiro, n.20, p.167-174, 1984. 
LEMOS, Carlos A.C. A higiene da habitação, a nova preocupação. In: A república ensina a morar (melhor). São Paulo: Hucitec, 1999. p.18-21. (Estudos históricos, 39).

LEMOS, Carlos A.C.; CORONA, Eduardo. Dicionário da arquitetura brasileira. São Paulo: EDART, 1972.

LIMA, Luciana Calixto. Elaboração de um software para especificação de sistema revestimento cerâmico. 78p. 2003. Tese (Doutorado) - Escola de Engenharia de São Carlos, Universidade de São Paulo, São Carlos, 2003. CD-ROM.

LIMA, João Filgueiras. Grande artista e grande ser humano. Jornal de Brasília, Brasília, 2 jul. 1998. Edição extra: Athos Bulcão 80 anos. p.7.

LOURENÇO, Maria Cecília França. Obra pública: ápice da arte moderna brasileira. In: TARELLO, Regina Andrade (Org.). O restauro de um mural moderno na USP: 0 afresco de Carlos Magano. São Paulo: Comissão de Patrimônio Cultural Pró-Reitoria de Cultura e Extensão Universitária da Universidade de São Paulo (CPC-PRCEU-USP), 2001.

. Operários da modernidade. São Paulo: Hucitec; EDUSP, 1995.

LOURENÇO, Maria Cecília França; TARASANTCHI, Ruth Sprung. Osiarte. São Paulo: Pinacoteca do Estado de São Paulo, 1985. Catálogo exposição.

MACIEL, Nahima. Da equipe do Correio Braziliense. Disponível em:<http:// www.brasiliense.hpg.ig.com.br/athos.htm>. Acesso em : 10 dez. 2005.

MAGUCCI, Antônio Celso. A manufatura e a pintura de azulejos em Portugal: da produção das primeiras faianças à grande industria. In: O REVESTIMENTO cerâmico na arquitetura em Portugal. Lisboa: Estar, 1998. p.17-64.

MANUAL básico de serigrafia. Cerâmica Industrial, São Paulo, v.8, n.5/6, p.18-20, set./dez. 2003.

MARTINHO, Maria Esther. Arte pública: o artista em uma nova ordem. Design e Interiores, São Paulo, ano 1, n.6, p.76-79, jan./fev. 1988.

MELO, Magda M. Síntese das artes na arquitetura de Oscar Niemeyer. Semina: Ciências Sociais e Humanas, Londrina, v. 24, p.121-130, set. 2003.

MINDLIN, Henrique E. Arquitetura moderna no Brasil. Tradução de Paulo Pedreira. Rio de Janeiro: Aeroplano/IPHAN, 2000.

MOITA, Irisalva. Cerâmica aplicada à arquitetura oitocentista em Lisboa. In: ALCANTARA, Dora (Org.). Azulejos na cultura luso-brasileira. Rio de Janeiro: IPHAN, 1997. p.11-39.

MONTELLO, Josué. Os azulejos de São Luiz. In: ALCÂNTARA, Dora. (Org.). Azulejos na cultura luso-brasileira. Rio de Janeiro: IPHAN, 1997. 
MORAIS, Frederico. Azulejaria contemporânea no Brasil. São Paulo:Editoração Publicações e Comunicações, [entre 1988 e 1990]. 2v.

Humanizador dos espaços de Brasília. Jornal de Brasília, Brasília, 2 jul. 1998. Edição extra: Athos Bulcão 80 anos.

NEUMEISTER, Alexandre. Identidade cultural e design. Kéramica, Coimbra, n.238, p.66-68, 1999.

NIEMEYER, Ana Maria; BULCÃO, Athos. Loja em Brasilia. Módulo, Rio de Janeiro, v.5, n.24, p.14-15, ago. 1961.

NIEMEYER, Oscar. Como Fellini e Nino Rotta. Jornal de Brasília, Brasília, 2 jul. 1998. Edição extra: Athos Bulcão 80 anos.

NOBRE, Ana Luiza. Athos Bulcão - Destino: Brasília. Arquitetura e Urbanismo, São Paulo, v.15, n.85, p.37-44, ago./set. 1999.

OSCAR Niemeyer: 50 anos de arquitetura. Módulo, Rio de Janeiro, n.97, p.47-71, fev. 1988. Edição especial.

OLIVEIRA, Maurício. A azulejaria mágica de Athos Bulcão. Disponível em:<http:// www.an.com.br/1999/out/19/0ane.htm>. Acesso em: 10 jan. 2004.

PARADA, Sérgio. Sérgio Parada: entrevista [abr. 2005]. Entrevistadora: Ingrid Moura Wanderley. Brasília.

PEDROSA, Mário. Dos murais de Portinari aos espaços de Brasília. São Paulo: Perspectiva, 1981.

PINHEIRO, Haroldo. Haroldo Pinheiro: entrevista [abr. 2005]. Entrevistadora: Ingrid Moura Wanderley. Brasília.

PINTO, Luís Fernandes. 0 azulejo dos arquitetos. In: O REVESTIMENTO cerâmico na arquitetura em Portugal. Lisboa: Estar, 1998. p. 69-101.

PONTUAL, Roberto. Athos Bulcão: rigor e humor. Apresentação da exposição individual Pinturas e Mascaras, Galeria Saramenha, Rio de Janeiro, 1992.

Azulejo, azulejar, azulejaria sua historia no Brasil de Nassau a Portinari. Módulo, Rio de Janeiro, n.54, p.48-52, jul. 1979.

RAMOS, Graça. Brasília de Athos. Correio Braziliense, Brasília, maio 2002. Disponível em:<http:/ /www2.correioweb.com.br/cw/EDICAO_20020519/sup_pen_190502_20.htm>. Acesso em: 10 out. 2005. 
REVENDO Brasília neu gesehen. Fotos de Mário Cravo Neto et al. Brasília: Goethe Institut; Fundação Athos Bulcão, 1994.

RODRIGUES, José Wasth. A casa de moradia no Brasil antigo. In: ARQUITETURA civil I. São Paulo: FAU/ USP, 1975.

Documentário arquitetônico: relativo à antiga construção civil no Brasil. 2.ed. São Paulo: Martins; EDUSP, 1975.

ROTOCOLOR. Manufacturing Printing System. System Brasil, Rio Claro. Manual e catálogo.

SEIBEL, Silene; MEYER-STAMER, Joerg; MAGGI, Cláudio. Globalização e os desafios para as industrias italiana, espanhola e brasileira de revestimentos cerâmicos. Cerâmica Industrial, v.6, n.6, p.28-38, nov./dez. 2001.

SANTOS, Luiz Domingos. Luiz Domingos dos Santos: depoimento. [jul. 2003]. Entrevistadora: Ingrid Moura Wanderley. Recife.

SAPORITI, Teresa. Azulejos portugueses padrões do século XX. Lisboa: Textype, 1998.

SEGAWA, Hugo. Arquiteturas no Brasil 1900-1990. 2.ed. São Paulo: EDUSP, 2002.

SICHIERI, Eduvaldo Paulo; LIMA, Luciana Calixto; GONÇALVES, Paulo Sérgio. Revestimento cerâmico: um panorama geral sobre o produto e sua utilização. In: SEMINÁRIO MATERIAIS \& DESIGN, 1997, São Carlos. São Carlos: UFSCar, 1997.

SILVEIRA, Marcele Cristiane. Influência dos revestimentos cerâmicos na composição estética das fachadas em projetos de arquitetura. 92p. 2002. Monografia (Iniciação Científica) - Escola de Engenharia de São Carlos, Universidade de São Paulo, São Carlos, 2002.

SIMÕES, João Miguel dos Santos. Azulejaria em Portugal nos séculos XV e XVI. 2.ed. Lisboa: Fundação Calouste Gulbenkian, 1990.

Azulejaria no Brasil. Revista do Patrimônio Histórico e Artístico Nacional, Rio de Janeiro, n.14, p.9-18, 1959.

1965

Azulejaria portuguesa no Brasil (1500-1822). Lisboa: Fundação Calouste Gulbenkian,

Presença e continuidade do azulejo português no Brasil. [S.I.:S.n.], 1980.

SIMPLICIDADE formal e uso de elementos modernos definem o pequeno edifício, adequado ao entorno. Projeto \& Design, São Paulo, n.222, p.36-39, jul. 1998.

O SISTEMA cerâmico: guia geral de cerâmica \& assentamento. Showroom, São Paulo, ano 5 , n.30 A, p.6-9, maio 1998. 
SISTEMA revestimento cerâmico. São Carlos: Universidade de São Paulo / Escola de Engenharia de SãoCarlos/Departamento de Arquitetura e Urbanismo/Grupo de pesquisa ArqTeMa Arquitetura Tecnologia e Materiais, 2003.

TELLES, Claudio. Apresentação da exposição individual pinturas e máscaras. Brasília: Itaú Galeria, 1992.

TELLES, Claudio. Sintonia de arte e arquitetura. Jornal de Brasília, 1997. In: Textos críticos selecionados, Brasília, Fundação Athos Bulcão.

TEIXEIRADE BARROS, Regina. Antônio Maluff. São Paulo: Cosac \& Naify; Centro Universitário Maria Antônia da USP, 2002.

TOCANTINS, Leandro. Santa Maria de Belém do Grão Pará: instantes e evocações da cidade. Rio de Janeiro: Civilização Brasileira, 1963. (Imagens da terra e do povo, 2).

TOLEDO, Benedito Lima. O azulejo: permanência e inovação. In: ALCÃNTARA, Dora. (Org.). Azulejos na cultura luso-brasileira. Rio de Janeiro: IPHAN, 1997.

UENO, Romilda Rosa. Proposta para o desenvolvimento do design de revestimentos cerâmicos. 168p. 2003. Dissertação (Mestrado) - Faculdade de Arquitetura e Urbanismo, Universidade de São Paulo, São Paulo, 2003.

UNIVERSIDADE FEDERAL DE SANTA CATARINA. Departamento de Engenharia Mecânica. Relatório do grupo Design. Florianópolis: [s.n.], [1999?]. Projeto Plataforma.

VALLADARES, José. Os azulejos da reitoria. Bahia: Universidade Federal da Bahia; Raízes Artes Gráficas, 1982. 


\section{acervos pesquisados}

\section{Acervo}

Biblioteca Central da Escola de Engenharia de São Carlos

CEDOC - Centro de Documentação do

Departamento de Arquitetura e Urbanismo da

Escola de Engenharia de São Carlos

Biblioteca da FAU- Faculdade de Arquitetura e Urbanismo da USP - Universidade de São Paulo

Biblioteca da FAU Maranhão

Biblioteca da Faculdade de Filosofia, Letras e Ciências Humanas da FFLCH - USP

Biblioteca do Instituto de Estudos Brasileiros USP

Biblioteca Comunitária da UFSCar

Biblioteca do Centro de Artes e Comunicação da UFPE

Biblioteca do Centro Cerâmico do Brasil

Biblioteca Central da UnB

Fundação Athos Bulcão
Endereço

Av. Trabalhador Sãocarlense, 400

São Carlos - SP

Av. Trabalhador Sãocarlense, 400

São Carlos - SP

Rua do Lago, 876

Cidade Universitária, São Paulo - SP

Rua Maranhão, 88

Higienópolis, São Paulo - SP

Av. Professor Lineu Prestes, 338

Cidade Universitária, São Paulo - SP

Av. Prof. Mello Moraes, Travessa 8, 140

Butantã, São Paulo - SP

Rodovia Washington Luiz

Cidade Universitária, São Carlos

Av. Cidade Universitária, Recife-PE

Rua N. Sra. do Carmo, 96

Santa Gertrudes - SP

Campus Universitário Darcy Ribeiro, Gleba 'A'

BCE, Brasília - DF

Setor de Autarquia Norte, Quadra 1, Bloco E, Brasília - DF 


\section{apêndice 1 entrevistas}

\section{Entrevista com arquiteto Sérgio Parada Realizada em abril de 2005}

Sérgio Parada é arquiteto formado em Curitiba, depois de formado, mudou-se para Brasília onde mora e trabalha. Realizou alguns projetos em parceria com Athos Bulcão e é amigo do artista. Conversamos em seu escritório onde me recebeu com muito entusiasmo. Sérgio Parada é mais uma das pessoas que demostrou enorme admiração, prazer e alegria em contribuir em um estudo sobre 0 Athos Bulcão. Começamos a entrevista falando sobre Recife, minha cidade, para logo depois entrarmos no assunto.

SÉRGIO: Bom, do Belém do Pará, eu lembro de um trabalho de Belém do Pará, que eu queria inserir uma obra de arte. O Luis Galvão é um artista que mora aqui em Brasília. Ele trabalha muito com madeira da Amazônia, ele vai a busca e pesquisa essas madeiras, que são restos de queimadas. Eu acho que é uma forma de manifestar preocupação com relação à conservação, meio ambiente. Ele faz trabalhos belíssimos e eu sempre quis colocar o trabalho do Luis Galvão em Belém, porque este aeroporto é a porta de entrada da Amazônia. Infelizmente não consegui sensibilizar as pessoas que administravam esta obra para a Infraero na tentativa de contratar um trabalho desses, o pessoal tem uma certa barreira. Acho que a obra de arte é algo que faz parte da vida humana, não é supérflua, pelo contrário, é uma coisa importante pra todos nós. No entanto, lembro-me vagamente, que o Luis Galvão me disse uma vez foi vendido um painel dele maravilhoso para Alemanha. Daí você fica com dor-de-cotovelo, e pensa:....Meu Deus do Céu, nós aqui não conseguimos fazer alguma coisa, aí isso às vezes me deixa um pouco frustrado, sabe, porque eu acho que é muito importante tê-los (os artistas plásticos) inseridos no nosso trabalho de arquitetos, fazer um trabalho em conjunto.

INGRID: Mas muitas vezes não consegue por que...

SÉRGIO: É eu acho que hoje em dia, eu não sei se você vai ter oportunidade de conversar com o Lelé, o Lelé esta lá na Bahia. Infelizmente ele está longe da gente, mas ele está lá. O Lelé é um arquiteto que mais tem desenvolvido trabalhos junto com Athos Bulcão, ele é um homem que tem ajudado muito o Athos, neste sentido, é um colega que tem se preocupado com a integração da arte com a arquitetura, e se preocupa em investir na obra dele, os trabalhos até meio alegóricos, no bom sentido, do Athos que dá um astral bom, principalmente nos projetos de obras hospitalares que o Lelé faz, que são maravilhosos. A gente vê como coexiste essa simbiose entre a arquitetura do Lelé e a obra de arte do Athos. Elas estão harmonizadas, juntas, como a gente vê no Teatro Nacional do Oscar Niemeyer, com os painéis do Athos que são maravilhosos, aqueles painéis em relevos com aquele jogo de sombra e luz. 
INGRID: Bom, você já pensou qual a função do painel nas obras de Athos?

SÉRGIO: Eu acho que é mais ou menos isso que eu te disse, eu acho que não penso isoladamente num painel. Por exemplo, quando eu projetei a minha casa, que tem um painel dele, eu nunca imaginei aquele painel colocado ali, como se fosse um quadro na parede não. Eu pensei naquele painel como se fizesse parte da arquitetura. Eu acho que se eu tirasse aquela composição da minha casa, hoje eu ia sentir como se ela tivesse nua, entende? Como se tivesse retirado o muro. Então, eu acredito, eu creio nisso, eu creio que não é a inserção de uma peça colocada ali na parede só, eu acho que ela compõe o espaço arquitetônico. Essa é a grande jogada no trabalho do Athos, ele consegue interpretar o espaço arquitetônico, com muita sensibilidade... É ele consegue inserir o trabalho dele da forma mais coerente possível com a arquitetura. Ele consegue sacar o jogo de luz, entende? A luz natural, como é que ela entra no espaço e como é que ela pode ser explorada e a grande interpretação do painel, o painel de azulejo, no caso. Já que nós estamos falando em painéis se você vai na Câmara dos Deputados, observe aquele grande painel lá no fundo, no salão verde. Se hoje tirar naquele painel dali, você dirá: Nossa! Aqui está faltando alguma coisa! Você chega ao Itamaraty, vê aqueles biombos, que foram recuperados agora, em madeira, fazem parte daquele espaço. Então, este é o grande mérito do trabalho do Athos. Não é um trabalho agregado, é um trabalho participativo, nasce com o espaço da arquitetura, assim que eu vejo o trabalho do Athos.

INGRID: Então, voltando à questão dos azulejos da sua casa, você disse que mandou confeccionar no Rio?

SÉRGIO: É, no Rio.

INGRID: Então eles fizeram a pintura e a queima por lá?

SÉRGIO: Isso mesmo. Eles mandaram a peça para analisarmos, para ver se a tonalidade estava OK. Normalmente, levamos lá para o Athos ver se aprovar. Somente após esta aprovação eles fazem a queima total do lote que você quer.

INGRID: E não tem ninguém aqui em Brasília que faça isso?

SÉRGIO: Olha, até pode ser que tenha. Mas eu segui rigidamente a indicação do Athos, pela experiência que ele já tem.

INGRID: Você saberia dizer se tem mais alguma outra empresa que o Athos trabalha para a execução dos azulejos?

SÉRGIO: Sei que tem essa empresa no Rio e outra em Minas Gerais. É isso aí, parece que em Minas Gerais também tem uma empresa. Deixa-me dar uma olhadinha aqui, se eu tenho uns desenhos dele para você. O Athos é que determina o tamanho da peça que serve de base. Acho que ele determina o tamanho da peça em função da dimensão do painel.

INGRID: O projeto do aeroporto de Brasília foi o primeiro? 
SÉRGIO: Bom, foi o primeiro lá pelo final dos anos 80 e inicio dos 90, por aí mais ou menos, não lembro direito. Foi quando eu quis inserir a obra do Athos no Projeto Aeroporto de Brasília. Eu acho que 0 aeroporto era uma obra pública, era o portão de acesso à cidade de Brasília. $\mathrm{Na}$ linguagem do projeto eu me preocupava com a representação da modernidade brasileira, e aí 0 Athos é uma pessoa fundamental para participar de um projeto desses com sua obra de arte. Foi neste momento que eu comecei trabalhar com ele.

INGRID: Foi então aí que você conheceu o Athos?

SÉRGIO: Olha, na realidade, sou de Curitiba, formado em Curitiba, entrei na faculdade em $69 \mathrm{e}$ saí em 73. Então eu vivi um momento da história da arquitetura onde o modernismo era uma corrente muito forte dentro do nosso ensino. Claro que lá em Curitiba a gente ouvia muito falar em algumas personalidades desta fase de nossa história. Depois, eu vim conhecer algumas dessas pessoas e quando me mudei para Brasília, me tornei amigos de algumas. Uma delas foi o Athos, o Athos eu já conhecia como estudante de arquitetura, quando você analisava as obras do Oscar Niemeyer, quando analisava Brasília, quando, eu me lembro que vi as primeiras imagens do Teatro Nacional, e o que me mais me chamou a atenção foi aquele painel em relevo com aquele jogo de luz. Aquilo me chamou muita a atenção e eu imaginava que era do Oscar, e não era, é um projeto do Athos. E assim muitos outros trabalhos onde tinha a inserção de azulejos, que eu acho uma coisa muito interessante. Acho que é também um resgate dentro do nosso modernismo, resgate da história da arquitetura brasileira com o uso dos azulejos, tanto dos portugueses, quanto dos franceses. Então, eu achei aquilo muito interessante, conheci o Athos aí, conhecia o Lelé de nome e sua maravilhosa obra, entre outros. Depois quando cheguei aqui em Brasília, vim a me tornar amigo de alguma destas personalidades de nossa cultura. É uma coisa muito interessante para minha geração, entende? Eu não faço parte da geração do Lelé, nem do Athos, nem do Oscar e nem sou dessas gerações mais novas. Sou daquela geração intermediária e que tínhamos no nosso ensino uma força muito grande, onde mostrava muito o fato de Brasília, o fato de Brasília que era um feito muito importante dentro do nosso ensino. E de repente, quando eu cheguei em Brasília e tive a oportunidade de conhecê-los pessoalmente, foi uma coisa maravilhosa.

INGRID: E por que você veio para Brasília? Você foi transferido, ou algo assim?

SÉRGIO: Não, não, eu vim pra cá por um convite. Na realidade vim mostrar um projeto, na época eu era muito jovem, tinha 25 anos. Formei-me com 21 pra 22 anos, qualquer coisa assim. Eu vim para Brasília apresentar um projeto num ministério aqui. Ai, uma empresa viu a minha apresentação, e me convidou para trabalhar. Naquela época, eu dava aulas nas faculdades de arquitetura, na PUC-Curitiba e na Federal e tinha meu escritório também. A época era diferente, eu mesmo jovem, já tinha o meu escritório. Aí esse pessoal me conheceu e quis me trazer para Brasília, para fazer parte de uma equipe multidisciplinar para desenvolver o projeto da Usina Hidrelétrica de Tucuruí, que é um projeto gigantesco, é um projeto industrial, coisa que um arquiteto não faz num escritório, só quando você está com uma grande empresa. E aquilo foi um desafio pra mim, daí eu achei interessante e vim, pedi licença nas faculdades, falei com meu sócio lá no meu escritório que eu ficaria seis meses fora, mas esses seis meses já faz quase trinta anos, entende? Não voltei mais. Porque achei que para mim era uma oportunidade viver em Brasília. Eu sei que isso fez uma mudança muito grande na minha cabeça, morar em Brasília não simplesmente saber de Brasília através de bibliografias, ou de impressões de outras pessoas, mas de viver aqui. Então, isso me atraiu muito, eu vim e comecei a conviver com todo esse tipo de trabalho, conseguir 
analisá-los, comentá-los, criticá-los. Isso era como uma escola, que para mim foi interessante demais. Por isso que eu dou muito valor a isso que está aqui à nossa volta, a toda essa cidade, a tudo isso. Não simplesmente por ser uma cidade-patrimônio, nem nada. Mas pelo conteúdo intelectual brasileiro que é do arquiteto, do artista plástico, do escritor, é de todos enfim, não é?!

INGRID: Gostaria de saber quais das suas obras tiveram a participação do Athos?

SÉRGIO: Do Athos, eu tenho, na realidade três trabalhos. Ele fez esse primeiro conjunto de painéis que está hoje no Aeroporto de Brasília, que eu acho que você pode até vê-los na Internet. Eu lembro perfeitamente quando o Athos fez esse conjunto de painéis para o aeroporto de Brasília.

INGRID: Esse conjunto é de quantos painéis?

SÉRGIO: São dois, o Athos disse, eu lembro de alguma coisa sobre o desenho, mas eu não lembro bem a frase, mas o que ele quis dizer com o desenho onde mostrava uma certa direção, se você olhar, observar o desenho geométrico que tem, parece uma seta, uma coisa que dá uma certa direção, uma certa dinâmica. Como seria o caso do aeroporto. E depois ele fez os azulejos da minha casa, que gentilmente como amigo ele me deu o projeto, ou seja, deu o desenho para que eu pudesse executar. E que para mim é uma coisa que eu tenho uma estima e um carinho imenso.

INGRID: Nossa... Imagino, hein!

SÉRGIO: Pois é, primeiro porque foi algo que nasceu dele como amizade, dele oferecer aquilo e que foram os primeiros desenhos dele do ano 2000. Então eu lembro que o azulejo foi feito no final 1999, no inicio de 2000, quando já estava aprovado, ele me mostrou algumas amostras e cores, aí ele chegou e disse assim: "Ah! Vou assinar, mas eu vou pôr 99 ou 2000?" - ele perguntou pra mim, aí eu disse assim, "Põe a data que você quiser" - , aí ele disse: "Eu vou por 2000, que é o primeiro do ano 2000". Então esse é um fato muito interessante.

INGRID: E ele assinou o azulejo?

SÉRGIO: Assinou, está impresso lá, eu tenho a assinatura aqui, e depois foi feita a impressão.

INGRID: E quem fez esse trabalho de impressão e de queima de azulejo?

SÉRGIO: Foi uma empresa indicada por ele, no Rio de Janeiro.

INGRID: E foi serigrafia?

SÉRGIO: Foi uma... Eu não sei qual que é a técnica. Eles imprimem sobre o azulejo. Inclusive eu tinha uma preocupação com relação à côr, em perder a côr. Porque parte do meu painel vai pelo exterior da casa. Ele me mostrou alguns desenhos com cores diferenciadas, mas ele disse assim "vou jogar" com as cores laranja, amarelo, azul e verde. O Athos tem isso, a policromia, você pode observar nos painéis dele. Aí ele disse assim "Vou usar as mesmas cores do aeroporto para Ihe homenagear". Ele teve uma frase também que eu achei engraçada, que eu não sei se ele lembra, porque eu gravo muito isso. Ele disse assim "Mas esse azulejo é muito agitadinho, igual 
você". (risos) O desenho, a geometria do azulejo é muito interessante. Depois ele fez nesse ciclo de trabalhos, um trabalho que eu lutei muito para ele fazer, que é um novo painel, que vai ser feito também no aeroporto, na área do shopping do aeroporto, no terraço panorâmico, um lugar meio aberto. Eu precisava fazer um barramento por causa do sol da tarde e eu pensei primeiramente num painel feito em vidro jateado, eu imaginava um painel em vidro jateado pra minimizar 0 impacto da luz. E fui com o Athos para dizer o que eu queria, convenci a Infraero a fazê-lo, pois toda empresa pública tem muita burocracia. Eu sempre aleguei a importância do trabalho do Athos na capital e num prédio público. Aí nós conseguimos que ele fizesse, e aí eu fui falar com ele sobre o tema, isso faz uns cinco anos, em 2000, 2001, alguma coisa assim, ou 2002, eu não lembro direito. Bom, daí eu disse para ele "Athos eu imaginava um painel em vidro porque o sol da tarde se põe..." aí ele com aquele jeito dele assim, porque ele fala calmo, me disse: "Ai Sérgio, mas isso aqui não vai ficar parecendo um box muito grande? Box de banheiro, não é. (risos)." Eu disse assim "Olha Athos, eu não sei, mas se for um box feito por você, fica um box muito bonito. (risos)." Mas daí a gente mudou, mudou a temática.

\section{INGRID: Aí o que foi que ele propôs?}

SÉRGIO: Propôs o aço pintado, como ele tem feito em algumas obras com o Lelé, ele fez com aço pintado um sistema modular de encaixes em US, com peças em US, em que uma encaixa na outra diferenciando os tamanhos, a largura delas e jogando aí o efeito policromático, que é fundamental na obra dele, onde ele exerce todo o domínio e sensibilidade no uso da cor. Eu tenho pressionado muito a Infraero para fazê-lo, eles não têm dado muita importância a isso, já cheguei até ao Presidente da Infraero. Numa visita ao aeroporto, comentei com o Presidente da Infraero a importância daquele painel naquele local, não só em homenagem ao artista, mas em homenagem à cidade, à obra onde o povo circula, entende? Mas infelizmente, até hoje não foi executado, mas eu estou ainda me empenhando de todas as formas possíveis, tentando ver se sensibilizo a Infraero em construí-lo, porque a burocracia do estado se tornou um inferno, entende? Então, é uma pena que às vezes as pessoas não agarrem isso como um motivo político e faça. Como Juscelino fez com Brasília, como grandes políticos já fizeram a obra de vários arquitetos através de sua vontade de ter aquele objeto construído em benefício da comunidade. Infelizmente para nós, este trabalho está lá, parece-me que em banho-maria, quando eu pergunto dizem que está em licitação, aí dizem que quando está para execução, alguém entrou com recurso. É uma pena, dá uma pena porque a obra do Terminal de Passageiros do Aeroporto de Brasília fica capenga. Para mim, como autor do projeto de arquitetura, vejo o espaço e sinto que falta alguma coisa. Este foi o terceiro trabalho que ele fez comigo.

INGRID: E você tem aí algum desenho desse painel?

SÉRGIO: Desse painel?

INGRID: Porque eu não estou conseguindo entender.

SÉRGIO: Esse painel?

INGRID: Sim. 
SÉRGIO: É como se tivesse um perfil em U, por exemplo. Ele tem um U, ele usa este U em várias dimensões. É uma peça vertical, alta, da altura toda de onde nós vamos colocar o painel, ele encaixa um $U$ no outro, entende? Daí ele joga com as dimensões variadas na largura, e com a dinâmica da cor. Este projeto está na Infraero. E o desenvolvimento foi feito por uma colega, arquiteta Marlene Freire. Ela desenvolveu com o Athos esse sistema.

INGRID: Ele vai do piso ao teto?

SÉRGIO: Do piso ao teto. Esta foi a terceira experiência que nós fizemos, onde fomos trabalhar juntos, principalmente com o uso da cor, e ele é uma pessoa que mostra isso no trabalho. Eu nunca tive dúvida nenhuma que a sensibilidade do Athos é enorme para entender o espaço arquitetônico, ele é uma pessoa crítica nesse sentido, ele é um homem que eu ouço muito o que fala. Porque eu acho que a opinião de pessoas assim agrega ao trabalho, eu acho que essa é a simbiose entre 0 arquiteto e 0 artista na sua plenitude. Nós, arquitetos, temos também um lado do artista, do tripé da formação do arquiteto, que a técnica, o humanismo e a arte, isso tudo se mistura quando se pega um homem ligado quase que exclusivamente à arte, ai é interessante você absorver a sensibilidade dessa pessoa, interpretar. Minha relação com o Athos, nesse sentido é muito interessante, porque eu ouço e analiso, procuro ter sempre este tipo de percepção.

INGRID: Que bom, você já continuou na outra pergunta que eu ia fazer...

SÉRGIO: Qual era?

INGRID: Era exatamente essa relação do arquiteto e do artista. Como é que é com o Athos?

SÉRGIO: Eu acho que todas as obras, as grandes obras de arquitetura, sempre tiveram essa simbiose, se você analisar na história da arquitetura sempre houve essa mistura, essa coisa forte, nós sabemos disso, não é?!

INGRID: O que achou desse trabalho em conjunto com o Athos?

SÉRGIO: Isso eu acho que se a gente tivesse mais oportunidade seria melhor ainda. Estou tentando cada vez mais promover, inclusive, outros artistas. Acho que isso é importante. Claro que às vezes, quando você pega um nome como Athos Bulcão, é mais fácil para aceitação, porque seu trabalho já é de domínio público. Então, as pessoas não colocam dúvida sobre o trabalho, mesmo quem não goste. Você sabe que isso tem muito, esses aspectos, tem mesmo gente que não gosta do trabalho do artista, mas não coloca em dúvida porque o artista tem nome, não é?!

INGRID: Não gosta, mas respeita.

SÉRGIO: Respeita. Se nós arquitetos tivermos condições de levarmos os novos artistas, e de repente nós, com a nossa capacidade, também, de interpretação e de análise desses trabalhos promovermos essas pessoas, é muito importante. Então, quando eu trabalho com o edifício, principalmente se for público, eu sempre tento trabalhar com artistas plásticos. 


\section{Entrevista com o arquiteto Haroldo Pinheiro}

Realizada em abril de 2005, em Brasília.

Haroldo Pinheiro é arquiteto formado pela Universidade de Brasília, além de ser amigo do Athos Bulcão, trabalhou com ele, inclusive, como desenhista, em seu ateliê. Haroldo Pinheiro recebeume em seu escritório, no centro de Brasília, foi muito solícito, amigo e demonstrou um enorme respeito e admiração por Athos Bulcão, igualmente a todos com quem conversei sobre 0 artista. Depois de lhe explicar o tema da minha pesquisa e sobre o que seria a entrevista, Haroldo Pinheiro começa logo falando sobre o trabalho do Athos Bulcão.

HAROLDO: A arte do Athos Bulcão está tão integrada, à arquitetura que você não consegue reconhecer o próprio edifício sem o trabalho dele. É como se fosse parte mesmo, como se fosse criado junto. Um exemplo que eu costumo citar com mais freqüência, com mais propriedade para isso é o Teatro Nacional. Realmente, até o leigo em arquitetura ou em arte, olha para o teatro e vê aquele jogo de luz e sombra como uma coisa que, vamos dizer, a arquitetura se não tivesse aquilo perderia muito, quer dizer, não seria o edifício. E ali há até uma curiosidade, o Athos pode falar sobre isso melhor do que eu, porque naquela época eu não estava nem ai para arquitetura, para essas coisas. Mas quando foi solicitado o trabalho para aquelas empenas do teatro a idéia era 0 azulejo, a idéia é que fosse 0 azulejo. E ele nesse sentido de compreensão da arquitetura, ele não pega simplesmente ali naquele trapézio para fazer um azulejo, para encher ali naquela escada, naquela proporção. Não. Ele procura ver o prédio nas três dimensões, sentir o volume do edifício no espaço, quer dizer, é um espaço livre importante ali, e ele sentiu que o azulejo seria muito frágil, mesmo que ele fizesse uma grade coisa vazada, ele não ia ter a força que tem, aquele jogo de volume, aquele jogo de luz e sombra, necessitava algo mais forte. Então eu acho fantástico isso. Todos os trabalhos que ele tem feito conosco, os que eu pude participar e que ele participou também e os que de minha autoria ele fez trabalhos integrados, ele sempre fez questão de ver a maquete, ou de ver as perspectivas, ou de ver os desenhos, para ele poder participar, dessa maneira assim integrada, a melhor palavra é integrada mesmo à arte, arte integrada à arquitetura. E de fato eu não conheço, já estive pensando muito em outros artistas e eu não conheço um, que consiga fazer isso com a mesma maestria, sabe, não conheço. Talvez a própria trajetória da formação dele, de ter encontrado tão cedo mestres como o Oscar Niemeyer, como Doutor Lúcio e de ter uma relação próxima assim de amizade com o Roberto Burle Marx, e de conviver no inicio com o Portinari, talvez isso tenha feito despertar essa intuição nele, essa qualidade, acho realmente fantástico.

INGRID: E qual foi o período que você trabalhou com ele?

HAROLDO: Bom, eu trabalhei com ele quando eu era ainda estudante, foi nos anos 70, na segunda metade dos anos 70 , eu já trabalhava no escritório do Lelé, já conhecia naturalmente o Athos Bulcão. Naquela época a gente estava trabalhando no Projeto do Hospital Sarah Kubitschek, que tem uns painéis muito bonitos do Athos lá. Originalmente tinha um, é um muro escultórico vazado, que está dentro do acesso do hospital. E então eu já conhecia o Athos e tinha até feito os desenhos desse painel na arquitetura do edifício, tinha admiração por ele, e eu sentia uma certa falta na minha formação artística na faculdade. Eu estudei na Universidade de Brasília, eu entrei na Universidade de Brasília em 73, e naquela época houve uma fase de transição onde os professores que tinham fundado a universidade em 1960, 62 haviam saído numa demissão coletiva em 65, um dos quais foi o Athos, outro foi o Lelé, o Oscar. E outros 
professores vieram para substituir, foi um período conturbado e começou a se estabilizar nos anos 70, eu tive até bons professores lá no Departamento de Artes, mas eu sentia um pouco a falta, sabe, da arte.

INGRID: Você fez arquitetura. Mas o curso de arquitetura era ligado ao Departamento de Artes?

HAROLDO: Porque naquela época a Universidade de Brasília tinha sido idealizada pelo Darcy Ribeiro, então, vamos dizer, existiam os Departamentos de Química, Departamento de Física e existiam os Institutos de Arte e de Arquitetura. Então, algumas matérias nós não fazíamos no próprio Departamento de Arquitetura, nós fazíamos no Departamento de Artes, ou no Departamento de Matemática, ou no Departamento de Engenharia. Enfim, a idéia era integrar mais os alunos, vamos dizer, fazer como se houvesse uma aproximação entre os alunos de diversos cursos. Darcy Ribeiro costumava dizer que a pessoa que consegue fazer um nível superior não precisa perder a universalidade do conhecimento, ela não pode fazer isso, mas tem que saber onde encontrar tinha que saber onde encontrar. Então, isso ajudava muito porque a gente entrava no Departamento de Estatística, entrava em diversos departamentos. Bom, e na arquitetura nós fazíamos essas matérias, por exemplo, de desenho de observação, fotografia, expressão e movimento, expressão e volume, tudo a gente fazia no Instituto, na área das artes do Instituto de Arte e Arquitetura, entendeu? O Athos inclusive deu aula lá, ele foi professor de muitos. Bons arquitetos por aí, eu acho, devem boa parte de sua formação a ele.

INGRID: Ele não foi seu professor?

HAROLDO: Não foi meu professor na Universidade. Ele saiu em 65, eu entrei em 73, 8 anos depois.

INGRID: Mas ele voltou a Universidade (UNB).

HAROLDO: Muito depois da anistia, já quando o Cristóvão foi reitor da universidade, ele voltou por um pequeno período. Mas ai já foi no final dos anos 80 , foi um pequeno período. Alguns outros professores voltaram também para arquitetura, o Glauco Carneiro, o Edgar Greto, que tinham sido também desses primeiros tempos da universidade. Bem, então voltando a sua pergunta, eu sentia uma certa fragilidade na minha formação, nessa área das artes, quer dizer, que arquitetura tem muito de artes também, você sabe: arte, técnica, história. E bem então quando nós terminamos o projeto do Hospital Sarah, eu era desenhista lá do escritório do Lelé e eu desenhava tudo direitinho, o Lelé era muito observador e crítico, e houve um branco no escritório, teve que dispensar muita gente. Lelé me chamou e falou assim: "Haroldo, o Athos Bulcão está precisando de uma pessoa para desenhar, para fazer aquarelas e desenhos lá com ele, você quer passar um período lá, enquanto a gente não retorna o escritório aqui, e não surge um trabalho ou outro?" Daí eu falei: "Claro que quero".Daí ele me apresentou o Athos, e houve uma empatia muito grande logo de início. E eu então passei, acho que, cerca de dois anos trabalhando com ele, no ateliê dele. E foi um dos melhores períodos da minha vida sabe, porque eu estava acostumando com aquela dinâmica de escritório de arquitetura, e obra, aquelas correrias, e no Athos não, tudo era tranqüilo, era calmo, trabalhava ouvindo musiquinha, sabe como é que é?! Ás vezes, a gente no meio da tarde parava para tomar um chá, um café e comer uns biscoitinhos, conversar um pouco. E eu sempre tive vocação para aprendiz, eu sempre gostei de conversar com pessoas mais velhas, sempre tive muito respeito pelos mais velhos, especialmente os com 
qualidades assim como o Athos, o Lelé, o Oscar, o Doutor Lúcio Essa turma toda do início de Brasília, gostava muito de ouvi-los, ficava mais ouvindo do que falando, naturalmente, e aí eu tive a oportunidade de aprender um pouquinho com eles.

INGRID: Qual era o seu trabalho no ateliê do Athos? Fazer os desenhos, as pinturas?

HAROLDO: É, fizemos azulejos também. Naquela época não tinha computador essas coisas a gente fazia com aquarela, com tira linhas, bico de pato e pincel, então eu fiz vários azulejos com eles...

INGRID: Bico de pato?

HAROLDO: Conhece tiralinhas, não conhece? Tem de diversos tamanhos. Você deve ter usado, já não se usa mais. Você abre e fecha, você dá a espessura da linha, e você pinga o guache, a aquarela, o nanquim, seja o que for e você girando faz a linha mais fina ou mais grossa.

INGRID: O tira linhas é a mesma coisa do bico de pato?

HAROLDO: É. O tiralinhas já é o bico de pato mais fininho, entendeu? Eu acho que chama tiralinhas porque você faz primeiro o traçado à lápis e depois ele se sobrepõe. Agora o bico de pato tem maiores, esse daqui é mais para o compasso eu esto usando no compasso. Então, o Athos fazia o primeiro esboço.

\section{INGRID: Ele fazia o esboço no lápis?}

HAROLDO: À lápis, definia cores, essas coisas. Primeiro, eu desenvolvia à lápis mesmo, e fazia um outro na seqüência, até ele achar que estava bem, aí fazia uma cor. No começo ele mesmo que sempre fazia a cor, misturava ali a cor até chegar na tonalidade que ele queria, e ele é craque nisso, impressionante como, como dizer? Ás vezes, um pouco mais de uma cor ou outra, altera a cor final e aí depois que ele definia eu montava as pranchas. Montava as pranchar grandes, nos lugares onde ele costumava apresentar ele fazia um, por exemplo, no caso dos azulejos, que the interessa mais, ele fazia um desenho maior, assim digamos uma composição com 16 peças (4 $\mathrm{x}$ 4), digamos que fosse azulejo de $20 \times 20 \mathrm{~cm}$, um painel de $4 \times 4$ e do lado fazia um desenho com as medidas todas e tudo...

INGRID: Um desenho técnico?

HAROLDO: É, um desenho já com as medidas para poder fazer e silk screen no azulejo. E depois ele fazia isso em papel, como que chamava mesmo?

INGRID: Vegetal?

HAROLDO: Não, não. É um papel branco, grosso assim, papel...?

INGRID: Couché? 
HAROLDO: É, acho que é papel couché, um mais grossinho. É isso mesmo, e depois mandava emoldurar colocava vidro e tudo, fazia uns quadros. Em alguns lugares você até encontra, na parede, esses trabalhos de apresentação dele. Na Câmara dos Deputados, onde ele fez alguns painéis, lá eu me lembro que tem. Tem inclusive alguns que foram desenhos meus, que foram de arte final minha. Ás vezes não eram azulejos, às vezes eram painéis em módulos ou painéis em madeira, ripados de madeira, eu fiz muito isso também, aquilo que a gente faz caprichado, fizemos muito para Câmara na época. Inclusive, lá no Salão Verde.

INGRID: E ainda tem algum desses desenhos lá?

HAROLDO: Tem, tem lá na sala do diretor de administração. Lá tem um que é o desenho do próprio painel do Salão Verde, com azulejo azul e branco, com vários desenhos, e ele tem esse original lá. Tem um muro divisório que é verde, em módulos, aquele eu desenhei também. No salão, acho que de armas, onde tem medalhas, tem um painel grande azul, bem grande, acho deve ter uns três metros e meio de altura, por uns quinze de comprimento, de ripado de madeira todo pintado de azul, também fui eu que desenhei. Então, nesses trabalhos que já envolviam constituição, ele sempre contratava um arquiteto para fazer um detalhamento, um desenho executivo, o desenho técnico para montagem. Daí eu cheguei a fazer também alguns desenhos para o Athos. Bom, então nesse período, era mais isso que eu fazia mesmo, sabe como é? Eram mais esses trabalhos assim, muitas vezes o Athos viajava, eu ficava sozinho. Ele tinha uma empregada, já naquela época, não sei se você já ouviu falar dela? A Cândida?

INGRID: É a que pinta?

HAROLDO: Que pinta também é. Hoje já faz exposições culturais tudo. Ela ficava observando também, levava para o quarto dela e começava a pintar tentando imitar o Athos. Aí um dia, 0 Athos descobriu aquelas máscaras, aquelas coisas que ele faz, tem até uma ali no topo desse armário, e a Cândida tentava imitar essa coisa aí, e um dia o Athos viu e veio à tona. Ele disse que ela deveria procurar o caminho dela, algo que tivesse a ver com a cultura dela, essas coisas. Então, ela passou a pintar, eu mesmo tenho um trabalho que comprei em uma exposição dela. Normalmente ela pega uma dessas frases bíblicas assim: Disse Salomão, e tal, e pinta em cima daquilo.

INGRID: Que legal!

HAROLDO: Muito interessante, muito interessante mesmo. Também, teve um bom professor! Um professor particular!

INGRID: Então Haroldo, depois dessa fase, desses dois anos, você ainda fez algum trabalho com 0 Athos? Você voltou a trabalhar com ele?

HAROLDO; Não, aí nós ficamos muito amigos, eu virei um freqüentador da casa dele, onde eu conheci muita gente agradável também, artistas como o Luis Áquila, como 0 ... Como chama? Um escultor que tinha um apartamento aqui em Brasília na 106. Ele e o Athos eram muito amigos também, e então eu conheci muita gente lá. Normalmente todo domingo à noite a gente ia jantar na casa do Athos e eles convidavam sempre três ou quatro pessoas, Luis Humberto, fotógrafo e arquiteto e outras mais. Pessoas que, às vezes, eu conheci através do Lelé, do Oscar Niemeyer, 
do Doutor Lúcio, que eu encontrava lá na casa dele também. Oscar Niemeyer sempre que vinha à Brasília ia lá também. E o Dr. Lúcio também. Então, eram reuniões, assim, muito agradáveis, onde conversava-se sobre estas questões de política, de arquitetura, arte em geral. Eu freqüentava muito essas reuniões, tanto que, o Athos foi até padrinho do meu primeiro casamento, em 1980, quando eu casei a primeira vez, ele foi meu padrinho. Depois, já como arquiteto naquele tempo, me formei em 80, demorei um pouco a formar, de um lado por questões políticas nos anos 70, tudo foi muito conturbado aqui na Universidade de Brasília, e por outro lado porque eu também trabalhava, gostava muito desse trabalho com o Lelé e depois com o Athos. Depois eu voltei a trabalhar com o Lelé de novo e até hoje faço trabalhos junto com o Lelé, aqui no meu escritório. E aí nos meus trabalhos eu passei a solicitar também a ajuda do Athos, fosse para fazer um painel, um azulejo, uma divisória, uma coisa assim, fosse para definir a composição cromática, às vezes num auditório fazer as poltronas, tapetes, parede. Sempre tem essa questão nos auditórios, a gente precisa, às vezes, dar algumas soluções acústicas. Então, normalmente, a gente procura deixar uma parede para ele, uma parede em tecido e uma parede no final, privada, prorrogada, uma coisa assim, e uma parede lateral para volumes, para ajudar na acústica. Ele faz isso muito bem, quer dizer, ele faz um painel artístico grande, mas também com efeito acústico. Ele fez muitos auditórios do Oscar Niemeyer, do Lelé, e tudo que tem esses painéis. O Athos fez um azulejo para minha casa, é um desenho que ele fez para mim, é uma composiçãozinha básica, de três para um. A cor é um pouco diferente, e um é o inverso do outro. Então, a cada três iguais tem um diferente, e são montados em posições variadas, formam uma grade. Uma parede longa que eu fiz na minha casa, que sai da sala de jantar e vai para varanda, na churrasqueira, uma parede comprida....

INGRID: E são esses dois tons de amarelo?

HAROLDO: São esses dois tons de amarelo. E como eu falei, o desenho invertido sempre montado assim nessa proporção três para um, três para um e evoluindo assim. Esse outro aqui eu fiz para Caixa Econômica de Minas Gerais. Também eram, se não me falhe a memória, uma composição de três para um, que também forma um desenho assim, bem variado. Esse daqui são cores que a Caixa usa também.

INGRID: Então, várias vezes você contou com a colaboração do Athos?

HAROLDO: Sim, sim...

INGRID: Por muito tempo?

HAROLDO: Em diversos projetos, quer ver aqui...Esse aqui é do Sérgio, Sérgio Parada, que você esteve com ele.

INGRID: É, ele me mostrou....

(Haroldo começa a mostrar imagens de projetos e vai comentando o que lembra de cada um).

HAROLDO: Esse daqui eu desenhei, esse daqui é do vice-presidente. Na casa do vice-presidente da República tem um painel de mármore e granito em relevo. 0 mármore é mais sacado e 0 granito é recuado. Esse é o que eu lhe falei, esse aí é o primeiro que eu desenhei dele, que é o do 
Hospital Sarah Kubitschek. É um muro com painéis em madeira, em "L", com recortes assim. É muito bonito, fica no acesso do hospital. Essas são do Sarah, mas são posteriores, não são originais não, foi já na reforma. Esse daqui mesmo foi um projeto que eu fiz junto com o Lelé, um auditório ali para o Sarah, está vendo esses parafusos, esses comprimidos aqui, é um auditório de um hospital, esse daqui tem, vamos dizer... Ele funciona acusticamente. Olha esse que eu lhe falei que tem o desenho de apresentação, que está na parede do diretor lá, esse eu acho fantástico. Esses são do Itamaraty, são réguas de madeira com placa de metal pintado, esse daqui é bem anterior, quem detalhou esse projeto foi o Oscar Niemeyer com o Milton Ramos, um arquiteto mais antigo, que também tem muita amizade com o Athos. Quando eu fui presidente do Instituto de Arquitetos, ofereci uma recepção para o presidente, para 0 então presidente da União Internacional de Arquitetos, um grego chamado Garcia. E eu ofereci a recepção nesse salão, ele ficou encantado, uma pessoa muito culta, muito inteligente. Esse é bem antigo, um dos primeiros que ele fez, é lá na cobertura do edifício da Manchete, no Rio, numas caixas que tem em cima do teto, casa de máquinas, caixa d'água, bem antigo. Esse daqui é outro projeto que eu fiz com o Lelé, esses também são de um auditório, um painel acústico. Esse daqui foi um projeto meu, a casa do Hamilton, uma parede longa...

INGRID: Esse eu não conhecia não...

HAROLDO: É, ele fica bem bonito porque é uma parede. Quando você entra da rua na quadra, ela é a segunda casa da esquerda. Então, é um painel que fica bem na rua, ele cruza todo 0 terreno, desde o início até o final do lote. Então, quando você entra na rua, você já vê, e como tem essa distância, essa perspectiva, então ele forma esses desenhos maiores.

INGRID: Então esse é um painel externo?

HAROLDO: Ele é um painel externo, não sei se eu tenho o projeto aqui. Outro dia meu irmão pediu para ver, por algum motivo. Esse já é meio grade como o da minha casa.

INGRID: Esse eu também não conheço.

HAROLDO: Esse de quem é? Ah! É da casa de um arquiteto também, o Luis Henrique. Agora esses são acústicos, relevos em madeira. Esse daqui é exatamente um projeto que nós fizemos, foi feito aqui no meu escritório, fiz junto com o Lelé, é o Hospital Sarah de Fortaleza, um dos projetos que eu gosto muito.

INGRID: Tem até uns muros fora, não é?

HAROLDO: Tem, tem uns muros, exatamente em argamassa armada. Esse painel é num auditório aqui atrás. Outra coisa que eu gosto muito é esse trabalho do Athos, por exemplo, como eu estava comentando com você, essas questões de composição cromática. Normalmente é ele que define, quer dizer, além do painel dele, é ele que define as cores de cadeiras, de piso, teto. Sempre pegando cores de linha (de produção). Ele faz muitos trabalhos assim, com esses semicírculos, que vão formando esses desenhos aleatórios. Esse foi feito aqui no meu escritório também, é o Sarah lá de Minas Gerais, o Hospital Sarah de Minas Gerais, bonito também. Esse é do hospital aqui do Lago Norte. Aliás, se você tiver oportunidade vá no Lago Norte. Esse é um prédio que o meu irmão fez lá com a Universidade, o Instituto de Artes. Um projeto do meu irmão 
Cláudio, não sei se ele está aí, ele fica numa sala aqui do lado. Olha esse daqui é de um hospital, tá vendo? Lago Norte, esses já são mais recentes, são meio boleadinhos, eu acho que ele fez nos hospitais que eu fiz, no de Salvador, de Belo Horizonte, de Fortaleza, eles são um perfil em "I". Esses calendários aí tem muitas fotos interessantes dos trabalhos dele. Esse daqui fica ali no teto, ali do edifício que chama Torre de Noiva, é ali no Anexo do Buriti, é um prédio do Oscar Niemeyer, são três círculos, três pastilhas por fora, por isso chama Bolo de Noiva, faz dois volumes, o prédio faz uma ligação com o Itamaraty e aí na época do regime militar ainda, colocaram a obra como se fosse uma obra de Segurança Nacional. Então, o Oscar não participou, nem acompanhou a obra, quem construiu foi até a empresa do Sérgio Naya, aqueles prédios que caíram lá em Recife, e aí eles alteraram muitos projetos, as provas(...),alteraram muitos projetos e uma das bobagens que eles fizeram é que eles transferiram as casas de máquinas e de ar condicionado para cobertura, entendeu? Então eram três volumes, eles fizeram três casas de máquina em cima e iam fazer mais uma, mais um volume. Na visão dos engenheiros, dos caras lá, era um bolo de noiva mesmo, vamos colocar mais uma camada em cima.

INGRID: Mais um andar...

HAROLDO: Depois quando começou a vir a abertura, essa coisa toda, aí voltaram a procurar 0 Oscar. Oscar, naturalmente, não aceitou que fizesse mais um andar no edifício e pediu para 0 Athos dar um jeito naqueles volumes que ficavam em cima. Ai o Athos fez assim uns trabalhos em azul, em tons de azul e branco, pensando em disfarçar um pouco os andares com as nuvens acima.

INGRID: Você disse que normalmente não conseguiu achar nenhum artista que trabalhasse tão bem quanto o Athos. Mas você chegou a fazer algum trabalho em parceria com outros artistas?

HAROLDO: Não, não....Nunca encontrei uma pessoa que fizesse, quer dizer, veja bem, que fizesse trabalhos assim como ele faz, trabalhos integrados. Artistas que fazem trabalhos para serem apostos, quer dizer, colocados sobre, é esses sim, escultores, e você deixa algum local para escultura, você tem vitrais, tem a Mariana Perretti que faz vitrais muito interessantes, trabalha muito com o Oscar também. Mas, dessa maneira integrada assim não. Tanto que, às vezes, quando há dificuldade de fazer um trabalho com o Athos, seja quando ele está muito atarefado e eu aí percebo, e não quero, e ainda mais nesses últimos períodos. Aí eu prefiro eu mesmo fazer. Procuro me lembrar das coisas que ele me ensinou, alguma coisa e daí eu faço tudo.

INGRID: Já que você trabalhou lá com ele, podia falar um pouco sobre qual a função do painel na obra de arte?

HAROLDO: Num painel, você diz assim de azulejo especificamente? Bom, normalmente é essa coisa da integração arquitetônica, quer dizer, quando a gente faz uma especificação num projeto, escolhe o material, vamos dizer seja pela pesquisa ou técnica, mas a gente quer que tenha uma qualidade de observador, como é o caso, como são os casos desses painéis acústicos, nos auditórios, ou apenas entrar na composição do espaço. Às vezes a gente tem, vamos dizer, um ambiente que por alguma circunstância está um pouco mais estreito do que a gente gostaria que tivesse. No caso, muito largo, essa fiação do Salão Verde lá da Câmara dos Deputados. Quer dizer, um Salão Verde que antigamente tinha vista para Praça dos Três 
Poderes quando o Oscar fez a reforma, foi o Lelé quem detalhou e ampliou isso em 15 metros de dimensão, cresceu para poder fazer um bloco de liderança e liberar de novo o Salão Verde, o Salão Azul para fazer o Hall dos Dois Plenários, então tem que ser um ambiente espaçoso, generoso. Ele perdeu a vista para Praça que dava essa transparência, aumentava o espaço, ficou terminado numa parede. Tinha até um jardim, uma coisa assim, e então o Athos fez esse azulejo aqui que acaba resultando numa coisa mais vazada, que da um certo sentido de profundidade, e às vezes corrige mesmo a proporção ou ambientação que se pretende e que por algum motivo não foi possível. Então, ele fica uma coisa meio vazada, o jardim está muito feio agora, esse jardim originalmente era do Burle Marx, faz uma pérgola aqui, esse painel de azulejo continua para baixo e continua para cima, tem outros ambientes embaixo e em cima. Em cima dessa terra tem uma grade que entra luz natural, um tipo de grelha por onde entra luz natural e aqui tem uma pérgola, que até estrutura esse pavimento, que dá sustentação para essa laje, que apoia. Por trás desse azulejo é uma cortina de concreto estrutural. E então, nessa pérgula formam umas bacias assim com plantas e embaixo é 0 jardim direto que sobem as plantas também. Então, o painel se mistura com a vegetação do Burle Marx ,que era muito amigo do Athos, trabalhavam muito bem juntos, e dá, então, uma sensação de profundidade, esse anjo de assas cortadas é do Sesquiate, bem próprio para época de ditadura, quando foi feita essa ampliação, é um anjo com asas cortadas.

INGRID: Esse painel é lindo! Vemos geralmente no Jornal, na televisão.

HAROLDO: Normalmente eles pegam todo o fundo. Então, no meu entendimento, a função desses painéis é justamente, vamos dizer, enriquecer e às vezes corrigir determinada dificuldade que a gente tem. Naquelas escolinhas, que a gente fez naquele projeto do Lelé, que eu ajudei a fazer em alguns lugares, que teve no Rio, aqui em Brasília, em Salvador. São escolas de construção industrial em que se buscava um custo baixo, tudo o que tinha ali tinha que está. Então, os painéis de portas bivotantes que compunham as fachadas dos edifícios e tinham também um desenho múltiplo do Athos, a gente compunha. Ele dava uma orientação, ele fazia os desenhos dele. $\mathrm{E}$ nas obras, quando a gente fazia os projetos, eram muito repetidos, a gente fazia composições várias nesses painéis. Então, tinha um desenho, ele fez um desenho, de um conjunto de portas para as escolas do Rio, outro para as escolas de Salvador, outro para as escolas de Brasília, então dá uma identidade.

INGRID: Cada cidade tem um conjunto?

HAROLDO: Em Salvador tinham as escolas e tinham as creches, então as escolas tinham um desenho, as creches tinham outro...

INGRID: Mas isso foi repetido?

HAROLDO: Muitas vezes, "N" vezes. São esses painéis das escolinhas...Se eu não me engano, o que tem num livro desse são as que eu fiz, são as de Brasília, eu que montei, em cima do desenho industrial do Lelé, quer dizer, era um jogo de peças de arquitetura, de lajes e a gente fazia a composição de acordo com o terreno, com o tamanho da escola, e os painéis faziam aquela composição, davam assim uma personalidade ao prédio. As obras com o Lelé, inicialmente esquadrias e depois estrutura edifício, depois tem algumas obras que nem foram eles que fizeram todas não. Isso daqui é a estrutura de um prédio lá do Lago Norte que eu queria que você desse 
uma olhada. Vou lhe mostrar a parte interna que tem uma participação muito intensa do Athos. Esse daqui foi feito aqui no meu escritório, é lá de Fortaleza e outros mais. Esse daqui é a Prefeitura de Salvador, que é um edifício que foi construído em doze dias.

INGRID: Vi uma palestra do Lelé que ele mostrou algumas coisas, acho que mostrou esse projeto de Salvador.

HAROLDO: Esse daqui foi muito impressionante, esse foi o Gravia que fez...Esse de Salvador foi feito aqui no meu escritório também, é uma adaptação, esse projeto originalmente era para ter sido feito em argamassa armada, em pré-moldado de argamassa armada, houve um problema, uma briga lá. Eu tinha até ido para Salvador para fazer esse projeto lá, com o Lelé, aí deu uma briga e eu voltei para Brasília. Anos depois eu retomei e aí adaptamos para aço. Tem muito trabalho do Athos ai dentro também, esse daí foi o Gravia que construiu também. Eu queria lhe mostrar o do Lago Norte. Esse prédio aqui, bom.... Aqui é a parte do Centro de Estudos, tem um auditório que tem um trabalho do Athos numas das paredes. Aqui é a escolinha para crianças com AVC Acidente Vascular Cerebral, então, é aquela estrutura que eu Ihe mostrei, muito bonita essa estrutura, é um vão livre grande, tem quarenta metros, quarenta e cinco metros de diâmetro, uma coisa assim. Estamos estudando outro, que será implantado lá no Amazonas que está em fase de anteprojeto ainda, que tem o dobro, tem cem metros de diâmetro, bem mais alto. É 0 Museu da Madeira, que vai fazer lá em Macapá, é uma estrutura muito semelhante, mas imagina só, com cem metros de diâmetro...

INGRID: É enorme.

HAROLDO: É uma estrutura realmente...tem que passar por túnel do vento, tudo isso. Então, aqui dentro tem umas divisórias, tem uns armários, como o vão é todo livre ele é todo dividido por armários, por divisórias e em todos tem a participação do Athos. Esse daqui é onde tem ginásio, campo de basquete, piscina coberta, essas coisas assim. Tem também os desenhos do Athos internos aqui, uns painéis dele, quase quadros, é um negocio japonês, assim meio redondo e tem um brise, um brisezinho, que vai variando a cor ao longo dele, muito bonito também. É um trabalho que o Lelé, vamos dizer, exigiu muito do Athos. Procurou muito a contribuição do Athos.

INGRID: Você sabe dizer, se o Athos se preocupa com que tipo de azulejo usar? Que tipo de argamassa? Ou não?

HAROLDO: Não, isso daí quando é o caso do azulejo, isso ele deixa a cargo do arquiteto ou do engenheiro da obra, uma coisa assim. Quando é um painel que exige montagem, um painel de divisória como esse que a gente estava comentando da Câmara, daí não, aí vai com detalhamento executivo toda essa complicação. Essa parte de madeira quem sempre trabalhou muito montando os painéis para ele foram os alemães da Técnica e Arte Madeira, do Verne e do Glauco, os pais até já morreram eles trabalharam, trabalham em um local, num estacionamento, os marceneiros são craques. Os trabalhos que eles fazem são preciosos, tanto estantes, quanto trabalhos artísticos, esses que você viu aqui. Quando eles fizeram lá do Quarteirão, madeira pintada, muito bem pintada, esmaltada, então esses o Athos faz os desenhos executivos. Não é ele quem faz, ele contrata um arquiteto, 0 arquiteto faz um detalhamento e tudo naturalmente sem interferir no trabalho dele, quer dizer, fazendo o que ele quer que faça. Agora no azulejo não, o procedimento é sempre o seguinte: ele faz o desenho dá uma mostra de cor, manda fazer em umas três firmas 
de azulejos. Na verdade, duas firmas de azulejos que normalmente fazem os trabalhos, uma no Rio, que chama Azularte, onde eu costumo, inclusive, mandar fazer alguns trabalhos também, e outra em Belo Horizonte na Domos. Nessas empresas eles fazem o silk screen, preparam a máscara do desenho, com o desenho, e então eles imprimem umas amostras e mandam para 0 Athos aprovar. Às vezes eles pedem uma pequena correção de cor, e aí liberam. Essas são amostras que vieram para aprovação.

INGRID: E isso aí é feito em serigrafia, numa base já esmaltada, em terceira queima no azulejo branco?

HAROLDO: No azulejo branco, ou de outra cor. Azulejo branco, normalmente é branco, mas pode ser de outra cor. Às vezes o Athos define cores do piso, das paredes. Você vê que até em coisinhas simples assim a gente procura uma orientação dele e sempre fica uma coisa um pouco melhor, a gente arrisca e evita o erro. (risos)

INGRID: Você também manda fazer alguns trabalhos nessas empresas.... No Rio ou em Belo Horizonte?

HAROLDO: É, os azulejos dele, quando é ele que projeta eu sempre mando, por exemplo, o pessoal lá no Rio já sabe o que tem que fazer. O que eu mando, normalmente, a gente manda escrito no desenho. Deixa-me ver se tem um desenho aqui. É um projeto que eu fiz junto com o Lelé, eu mesmo fiz e construi a obra. Na época era feito no nanquim, agora já tem no computador, essas pranchas executivas. Então, verde, azul ultramar, com fundo branco e a gente faz essa um pouco mais clara, um pouco mais escura, padrão um, padrão dois, mostrando que é um desenho aleatório e tal. Mas sempre nessa proporção três para um, ele usa muito isso, às vezes tem outras proporções mais corriqueiras. Aí, a gente manda com os quantitativos.

INGRID: Você manda esse desenho, ou a cópia?

HAROLDO: Uma cópia do desenho, com $30 \%$ a mais com perdas e substituições. Hoje com computador faz até cópia colorida. Como eu falei, a gente fazia a cópia executiva em preto e branco e outra fazia em cor, em aquarela. Às vezes, a gente até fazia uns quadradinhos em tamanho natural, uma série de umas 20 peças em guache plastificado, com a quantidade, entendeu? Para mostrar para o cliente como fazia. Hoje com o computador está tudo mais simples, mais rápido, dá para fazer direto. 


\section{apêndice 2 lista de painéis do athos bulcão}

\begin{tabular}{|c|c|c|c|c|c|c|c|c|c|}
\hline item & ano & edifício & cidade & endereço & $\begin{array}{l}\text { localização no } \\
\text { edifício }\end{array}$ & arquiteto & material & medidas & cores \\
\hline 1 & & $\begin{array}{l}\text { Residência } \\
\text { Oswaldo Lobo }\end{array}$ & Brasília & & & Salviano Borges & cerâmica & $15 \times 30 \mathrm{~cm}$ & \\
\hline 2 & 1955 & $\begin{array}{l}\text { Hospital Sul } \\
\text { América (atual } \\
\text { Hospital da } \\
\text { Lagoa) }\end{array}$ & Rio de Janeiro & & $\begin{array}{l}\text { revestimento } \\
\text { exterior no } \\
\text { térreo }\end{array}$ & $\begin{array}{l}\text { Oscar Niemeyer } \\
\text { e Hélio Uchôa }\end{array}$ & azulejo & $15 \times 15 \mathrm{~cm}$ & $\begin{array}{l}\text { azul } \\
\text { branco-f }\end{array}$ \\
\hline 3 & 1956 & $\begin{array}{l}\text { Residência } \\
\text { Raymundo } \\
\text { Britto }\end{array}$ & Rio de Janeiro & $\begin{array}{l}\text { Rua Felix } \\
\text { Pacheco }\end{array}$ & & Jorge Hue & azulejo & & \\
\hline 4 & 1957 & $\begin{array}{l}\text { Igrejinha Nossa } \\
\text { Senhora de } \\
\text { Fátima }\end{array}$ & Brasília & SQS 307/308 & & Oscar Niemeyer & azulejo & $15 \times 15 \mathrm{~cm}$ & $\begin{array}{l}\text { azul } \\
\text { preto } \\
\text { branco-f }\end{array}$ \\
\hline 5 & 1958 & $\begin{array}{l}\text { Concessionária } \\
\text { Volkswagen }\end{array}$ & Rio de Janeiro & & & Hélio Uchôa & azulejo & & \\
\hline 6 & 1960 & $\begin{array}{l}\text { Edifico de } \\
\text { apartamentos }\end{array}$ & Rio de Janeiro & Av. Pausteur & terraço & Oscar Niemeyer & azulejo & & \\
\hline 7 & 1960 & $\begin{array}{l}\text { Oficinas da } \\
\text { Construtora } \\
\text { Rabelo }\end{array}$ & São Paulo & & & Oscar Niemeyer & azulejo & & \\
\hline 8 & 1960 & $\begin{array}{l}\text { Residência } \\
\text { Roberto } \\
\text { Pacheco }\end{array}$ & São Paulo & & & $\begin{array}{l}\text { Roberto } \\
\text { Pacheco }\end{array}$ & azulejo & & \\
\hline 9 & 1960 & $\begin{array}{l}\text { Edifício } \\
\text { Niemeyer }\end{array}$ & Belo Horizonte & $\begin{array}{l}\text { Praça da } \\
\text { Liberdade }\end{array}$ & fachada & Oscar Niemeyer & $\begin{array}{l}\text { ladrilho } \\
\text { hidráulico }\end{array}$ & & $\begin{array}{l}\text { preto } \\
\text { branco-f }\end{array}$ \\
\hline 10 & 1960 & $\begin{array}{l}\text { Hospital Sarah } \\
\text { Kubischek- } \\
\text { SARINHA }\end{array}$ & Brasília & & & Glauco Campelo & azulejo & & \\
\hline 11 & 1960 & $\begin{array}{l}\text { Residência } \\
\text { Selma Fonseca }\end{array}$ & Brasília & & & Sabino Barroso & azulejo & & \\
\hline 12 & 1961 & $\begin{array}{l}\text { Residência } \\
\text { Marco Paulo } \\
\text { Rabello }\end{array}$ & Teresópolis RJ & & $\begin{array}{l}\text { revestimento } \\
\text { externo }\end{array}$ & Carlos Leão & azulejo & & \\
\hline 13 & 1961 & $\begin{array}{l}\text { Residência } \\
\text { Sebastião Paes } \\
\text { de Almeida }\end{array}$ & Rio de Janeiro & $\begin{array}{l}\text { Av. Vieira } \\
\text { Souto }\end{array}$ & cobertura & Oscar Niemeyer & azulejo & & \\
\hline 14 & 1961 & $\begin{array}{l}\text { Antigas } \\
\text { instalações da } \\
\text { "Ultima Hora" }\end{array}$ & Brasília & & & $\begin{array}{l}\text { João Filgueiras } \\
\text { Lima }\end{array}$ & azulejo & & \\
\hline 15 & 1962 & $\begin{array}{l}\text { Banco } \\
\text { Econômico }\end{array}$ & Rio de Janeiro & $\begin{array}{l}\text { Assembléia } \\
\text { esq. Rodrigo } \\
\text { Silva }\end{array}$ & & $\begin{array}{l}\text { Ana Maria } \\
\text { Niemeyer }\end{array}$ & azulejo & & retirado \\
\hline 16 & 1962 & $\begin{array}{l}\text { Fundação } \\
\text { Getúlio Vargas }\end{array}$ & Rio de Janeiro & $\begin{array}{l}\text { Praia de } \\
\text { Botafogo }\end{array}$ & terraço & Oscar Niemeyer & azulejo & & $\begin{array}{l}\text { preto } \\
\text { branco-f }\end{array}$ \\
\hline 17 & 1962 & $\begin{array}{l}\text { Antiga sede do } \\
\text { DTUI }\end{array}$ & Brasília & & & $\begin{array}{l}\text { João Filgueiras } \\
\text { Lima }\end{array}$ & azulejo & & \\
\hline 18 & 1962 & $\begin{array}{l}\text { Residência } \\
\text { César Prates }\end{array}$ & Brasília & & & $\begin{array}{l}\text { João Filgueiras } \\
\text { Lima }\end{array}$ & cerâmica & $15 \times 30 \mathrm{~cm}$ & \\
\hline 19 & 1962 & $\begin{array}{l}\text { Residência } \\
\text { Sebastião Paes } \\
\text { de Almeida }\end{array}$ & Brasília & & & Carlos Leão & azulejo & & \\
\hline 20 & 1963 & $\begin{array}{l}\text { Residência } \\
\text { Moacir Gomes } \\
\text { de Souza }\end{array}$ & Brasília & & & Gaus Estelita & azulejo & & \\
\hline
\end{tabular}




\begin{tabular}{|c|c|c|c|c|c|c|c|c|c|}
\hline 21 & 1963 & $\begin{array}{l}\text { Residência } \\
\text { Benjamim Jacó }\end{array}$ & Brasília & & & Gaus Estelita & azulejo & & \\
\hline 22 & 1963 & $\begin{array}{l}\text { Banco } \\
\text { Econômico da } \\
\text { Bahia }\end{array}$ & Brasília & & & $\begin{array}{l}\text { Antônio Carlos } \\
\text { Guimarães }\end{array}$ & azulejo & & \\
\hline 23 & 1964 & $\begin{array}{l}\text { Residência } \\
\text { Salomão } \\
\text { Goldstein }\end{array}$ & Rio de Janeiro & Copacabana & & Hélio Uchôa & azulejo & & \\
\hline 24 & 1964 & $\begin{array}{l}\text { Residência } \\
\text { João Sergio } \\
\text { Marinho }\end{array}$ & Rio de Janeiro & $\begin{array}{l}\text { Jardim } \\
\text { Botânico }\end{array}$ & $\begin{array}{l}\text { Transversais do } \\
\text { Pacheco Leão }\end{array}$ & Sabino Barroso & azulejo & & \\
\hline 25 & 1964 & $\begin{array}{l}\text { Residência } \\
\text { Pedro Diogo } \\
\text { dos Santos }\end{array}$ & Rio de Janeiro & $\begin{array}{l}\text { Jardim } \\
\text { Botânico }\end{array}$ & & Sabino Barroso & azulejo & & \\
\hline 26 & 1964 & $\begin{array}{l}\text { Residência } \\
\text { Israel Pinheiro }\end{array}$ & Brasília & & & Gaus Estelita & azulejo & & \\
\hline 27 & & $\begin{array}{l}\text { Edifício de } \\
\text { apartamentos }\end{array}$ & Rio de Janeiro & $\begin{array}{l}\text { Av. Vieira } \\
\text { Souto }\end{array}$ & pilotis & Hélio Uchôa & azulejo & & \\
\hline 28 & 1965 & $\begin{array}{l}\text { Escola Classe } \\
\text { da Entrequadra } \\
\text { Norte } 407 / 408\end{array}$ & Brasília & & & Milton Ramos & azulejo & $15 \times 15 \mathrm{~cm}$ & $\begin{array}{l}\text { preto } \\
\text { branco-f }\end{array}$ \\
\hline 29 & 1965 & $\begin{array}{l}\text { Edifidio de } \\
\text { apartamentos } \\
\text { na SQN } 107\end{array}$ & Brasília & & & $\begin{array}{l}\text { Fernando } \\
\text { Burmeiser, } \\
\text { Mayume e } \\
\text { Sérgio Souza } \\
\text { Lima }\end{array}$ & azulejo & & \\
\hline 30 & 1966 & $\begin{array}{l}\text { Edifício } \\
\text { Manchete }\end{array}$ & Rio de Janeiro & $\begin{array}{l}\text { Rua do } \\
\text { Russel }\end{array}$ & terraço & Oscar Niemeyer & azulejo & & $\begin{array}{l}\text { azul } \\
\text { branco-f }\end{array}$ \\
\hline 31 & 1966 & $\begin{array}{l}\text { Residência } \\
\text { Plínio Pureza }\end{array}$ & Brasília & & & $\begin{array}{l}\text { João Filgueiras } \\
\text { Lima }\end{array}$ & cerâmica & $15 \times 30 \mathrm{~cm}$ & \\
\hline 32 & 1966 & $\begin{array}{l}\text { Torre de } \\
\text { televisão }\end{array}$ & Brasília & & restaurante & Lúcio Costa & azulejo & $15 \times 15 \mathrm{~cm}$ & $\begin{array}{l}\text { azul } \\
\text { branco-f }\end{array}$ \\
\hline 33 & 1967 & $\begin{array}{l}\text { Condomínio } \\
\text { Casa Alta }\end{array}$ & Rio de Janeiro & Av. Pasteur & $\begin{array}{l}2 \text { painéis } \\
\text { internos e } 1 \\
\text { externo }\end{array}$ & $\begin{array}{l}\text { Sérgio } \\
\text { Bernardes }\end{array}$ & azulejo & & \\
\hline 34 & 1968 & $\begin{array}{l}\text { Edifício de } \\
\text { apartamentos }\end{array}$ & Rio de Janeiro & $\begin{array}{l}\text { Rua } \\
\text { Cupertino } \\
\text { Durão }\end{array}$ & fachada & Hélio Uchôa & azulejo & & $\begin{array}{l}\text { azul } \\
\text { branco-f }\end{array}$ \\
\hline 35 & 1968 & $\begin{array}{l}\text { Palácio do } \\
\text { Itamaraty }\end{array}$ & Brasília & & $\begin{array}{l}\text { prédio } \\
\text { administrativo- } \\
\text { restaurante }\end{array}$ & Oscar Niemeyer & azulejo & & $\begin{array}{l}\text { azul } \\
\text { branco-f }\end{array}$ \\
\hline 36 & 1968 & $\begin{array}{l}\text { Hospital } \\
\text { Distrital de } \\
\text { Taguatinga }\end{array}$ & Brasília & & Pronto socorro & $\begin{array}{l}\text { João Filgueiras } \\
\text { Lima }\end{array}$ & azulejo & & \\
\hline \multirow[t]{2}{*}{37} & 1970 & $\begin{array}{l}\text { SMU-Setor } \\
\text { Militar Urbano }\end{array}$ & Brasília & & terraço & Oscar Niemeyer & cerâmica & $15 \times 30 \mathrm{~cm}$ & $\begin{array}{l}\text { azul } \\
\text { branco-f }\end{array}$ \\
\hline & & & & & bloco I subsolo & & & $15 \times 15 \mathrm{~cm}$ & $\begin{array}{l}\text { azul } \\
\text { verde } \\
\text { branco-f }\end{array}$ \\
\hline 38 & 1970 & $\begin{array}{l}\text { Residência } \\
\text { Professor } \\
\text { Antônio } \\
\text { Barbosa }\end{array}$ & Brasília & & & Glauco Campelo & azulejo & $15 \times 15 \mathrm{~cm}$ & \\
\hline 39 & 1971 & $\begin{array}{l}\text { Salão verde da } \\
\text { Câmara dos } \\
\text { Deputados }\end{array}$ & Brasília & $\begin{array}{l}\text { Congresso } \\
\text { Nacional }\end{array}$ & jardim interno & Oscar Niemeyer & azulejo & $15 \times 15 \mathrm{~cm}$ & $\begin{array}{l}\text { azul } \\
\text { branco-f }\end{array}$ \\
\hline 40 & 1971 & $\begin{array}{l}\text { Residência de } \\
\text { Ministro de } \\
\text { Estado }\end{array}$ & Brasília & & $\begin{array}{l}\text { Península dos } \\
\text { Ministros }\end{array}$ & $\begin{array}{l}\text { João Filgueiras } \\
\text { Lima }\end{array}$ & azulejo & $15 \times 15 \mathrm{~cm}$ & \\
\hline 41 & 1971 & $\begin{array}{l}\text { Sede do } \\
\text { Partido } \\
\text { Comunista }\end{array}$ & Paris & & & Oscar Niemeyer & azulejo & & \\
\hline 42 & 1971 & $\begin{array}{l}\text { Sede de } \\
\text { Editora } \\
\text { Mondadori } \\
\text { Milão }\end{array}$ & Milão & & & Oscar Niemeyer & cerâmica & $20 \times 20 \mathrm{~cm}$ & $\begin{array}{l}\text { preto } \\
\text { branco-f }\end{array}$ \\
\hline
\end{tabular}




\begin{tabular}{|c|c|c|c|c|c|c|c|c|c|}
\hline 43 & 1971 & $\begin{array}{l}\text { Residência } \\
\text { Mondadori }\end{array}$ & $\begin{array}{l}\text { St. Jean de } \\
\text { Cap Ferrat- } \\
\text { França }\end{array}$ & & & Oscar Niemeyer & azulejo & $15 \times 15 \mathrm{~cm}$ & $\begin{array}{l}\text { amarelo } \\
\text { branco-f } \\
\text { azul } \\
\text { branco-f }\end{array}$ \\
\hline 44 & 1972 & $\begin{array}{l}\text { Residência } \\
\text { Frederico } \\
\text { Gomes }\end{array}$ & Rio de Janeiro & $\begin{array}{l}\text { Rua Eduardo } \\
\text { Guine }\end{array}$ & $\begin{array}{l}2 \text { painéis } \\
\text { internos }\end{array}$ & Oscar Niemeyer & azulejo & $15 \times 15 \mathrm{~cm}$ & $\begin{array}{l}\text { azul } \\
\text { cinza } \\
\text { branco-f }\end{array}$ \\
\hline 45 & 1972 & $\begin{array}{l}\text { Residência de } \\
\text { Ministro de } \\
\text { Estado }\end{array}$ & Brasília & & $\begin{array}{l}\text { Península dos } \\
\text { Ministros }\end{array}$ & $\begin{array}{l}\text { Fernando } \\
\text { Burmeister e } \\
\text { Luiz Henrique } \\
\text { Pesssina }\end{array}$ & azulejo & & \\
\hline 46 & 1972 & $\begin{array}{l}\text { Residência } \\
\text { Ivany Valença }\end{array}$ & Brasília & & & $\begin{array}{l}\text { Ítalo } \\
\text { Campofiorito e } \\
\text { Luiz Mário } \\
\text { Xavier }\end{array}$ & azulejo & & $\begin{array}{l}\text { verde } \\
\text { laranja } \\
\text { branco-f }\end{array}$ \\
\hline 47 & 1972 & $\begin{array}{l}\text { Residência } \\
\text { Edson Lobão }\end{array}$ & Brasília & & & & azulejo & & \\
\hline 48 & 1972 & $\begin{array}{l}\text { Escola Classe } \\
\text { Entrequadra } \\
\text { Sul } 315 / 316\end{array}$ & Brasília & SQS 315/316 & & Horácio Borges & azulejo & $15 \times 15 \mathrm{~cm}$ & $\begin{array}{l}\text { amarelo } \\
\text { branco-f } \\
\text { azul claro } \\
\text { azul escuro } \\
\text { branco-f }\end{array}$ \\
\hline 49 & 1972 & $\begin{array}{l}\text { Escola } \\
\text { Maternal } \\
\text { Entrequadra } \\
\text { Sul 3154/316- }\end{array}$ & Brasília & SQS 315/316 & & Salviano Borges & azulejo & & \\
\hline 50 & 1972 & $\begin{array}{l}\text { Residência } \\
\text { Riacho Fundo }\end{array}$ & Brasília & & & José Kluft Lopes & azulejo & & \\
\hline 51 & 1972 & $\begin{array}{l}\text { Sede Social do } \\
\text { Clube do } \\
\text { Congresso }\end{array}$ & Brasília & & sauna e subsolo & $\begin{array}{l}\text { Anna Maria } \\
\text { Niemeyer }\end{array}$ & azulejo & $15 \times 15 \mathrm{~cm}$ & $\begin{array}{l}\text { azul } \\
\text { branco-f }\end{array}$ \\
\hline 52 & 1975 & $\begin{array}{l}\text { Centro } \\
\text { Administrativo } \\
\text { de Salvador/ } \\
\text { Prédio das } \\
\text { Secretarias }\end{array}$ & Salvador & & terraço & $\begin{array}{l}\text { João Filgueiras } \\
\text { Lima }\end{array}$ & azulejo & & \\
\hline 53 & 1975 & $\begin{array}{l}\text { Parque } \\
\text { Nacional } \\
\text { Histórico dos } \\
\text { Guararapes }\end{array}$ & Recife & & & $\begin{array}{l}\text { Armando de } \\
\text { Holanda }\end{array}$ & azulejo & $15 \times 15 \mathrm{~cm}$ & $\begin{array}{l}\text { azul } \\
\text { branco-f }\end{array}$ \\
\hline 54 & 1975 & $\begin{array}{l}\text { Estação } \\
\text { Rodoferroviária } \\
\text { de Brasília }\end{array}$ & Brasília & & & Oscar Niemeyer & cerâmica & $15 \times 30 \mathrm{~cm}$ & \\
\hline 55 & 1975 & $\begin{array}{l}\text { Edifício } \\
\text { Disbrave }\end{array}$ & Brasília & & posto Disbrave & $\begin{array}{l}\text { João Filgueiras } \\
\text { Lima }\end{array}$ & cerâmica & $15 \times 30 \mathrm{~cm}$ & $\begin{array}{l}\text { verde } \\
\text { amarelo } \\
\text { branco-f }\end{array}$ \\
\hline 56 & 1975 & $\begin{array}{l}\text { Edifício } \\
\text { Camargo } \\
\text { Correia }\end{array}$ & Brasília & & terraço & $\begin{array}{l}\text { João Filgueiras } \\
\text { Lima }\end{array}$ & azulejo & & \\
\hline 57 & 1975 & $\begin{array}{l}\text { Edifício Morro } \\
\text { Vermelho }\end{array}$ & Brasília & & terraço & $\begin{array}{l}\text { João Filgueiras } \\
\text { Lima }\end{array}$ & azulejo & & \\
\hline 58 & 1975 & $\begin{array}{l}\text { Embaixada da } \\
\text { República Sul } \\
\text { Africana }\end{array}$ & Brasília & & & $\begin{array}{l}\text { Desenvolviment } \\
\text { o do projeto: } \\
\text { Carlos M. da } \\
\text { Silveira e Ítalo } \\
\text { Campofiorito }\end{array}$ & azulejo & & \\
\hline 59 & 1976 & $\begin{array}{l}\text { Caixa } \\
\text { Econômica } \\
\text { Federal }\end{array}$ & Natal & & sede & $\begin{array}{l}\text { Cláudio } \\
\text { Meirelles Fontes }\end{array}$ & azulejo & & $\begin{array}{l}\text { amarelo } \\
\text { branco-f } \\
\text { azul } \\
\text { verde } \\
\text { branco-f }\end{array}$ \\
\hline 60 & 1976 & Edifício Gropius & Recife & $\begin{array}{l}\text { Praia de Boa } \\
\text { Viagem }\end{array}$ & fachada & $\begin{array}{l}\text { Vital M. T. } \\
\text { Pessoa de Mello }\end{array}$ & $\begin{array}{l}\text { cerâmica } \\
\text { esmaltada }\end{array}$ & $5 \times 5 \mathrm{~cm}$ & $\begin{array}{l}\text { branco } \\
\text { marrom }\end{array}$ \\
\hline 61 & 1976 & $\begin{array}{l}\text { Edifício Sede } \\
\text { da Telebrás }\end{array}$ & Brasília & & & Oscar Niemeyer & cerâmica & $15 \times 30 \mathrm{~cm}$ & \\
\hline
\end{tabular}




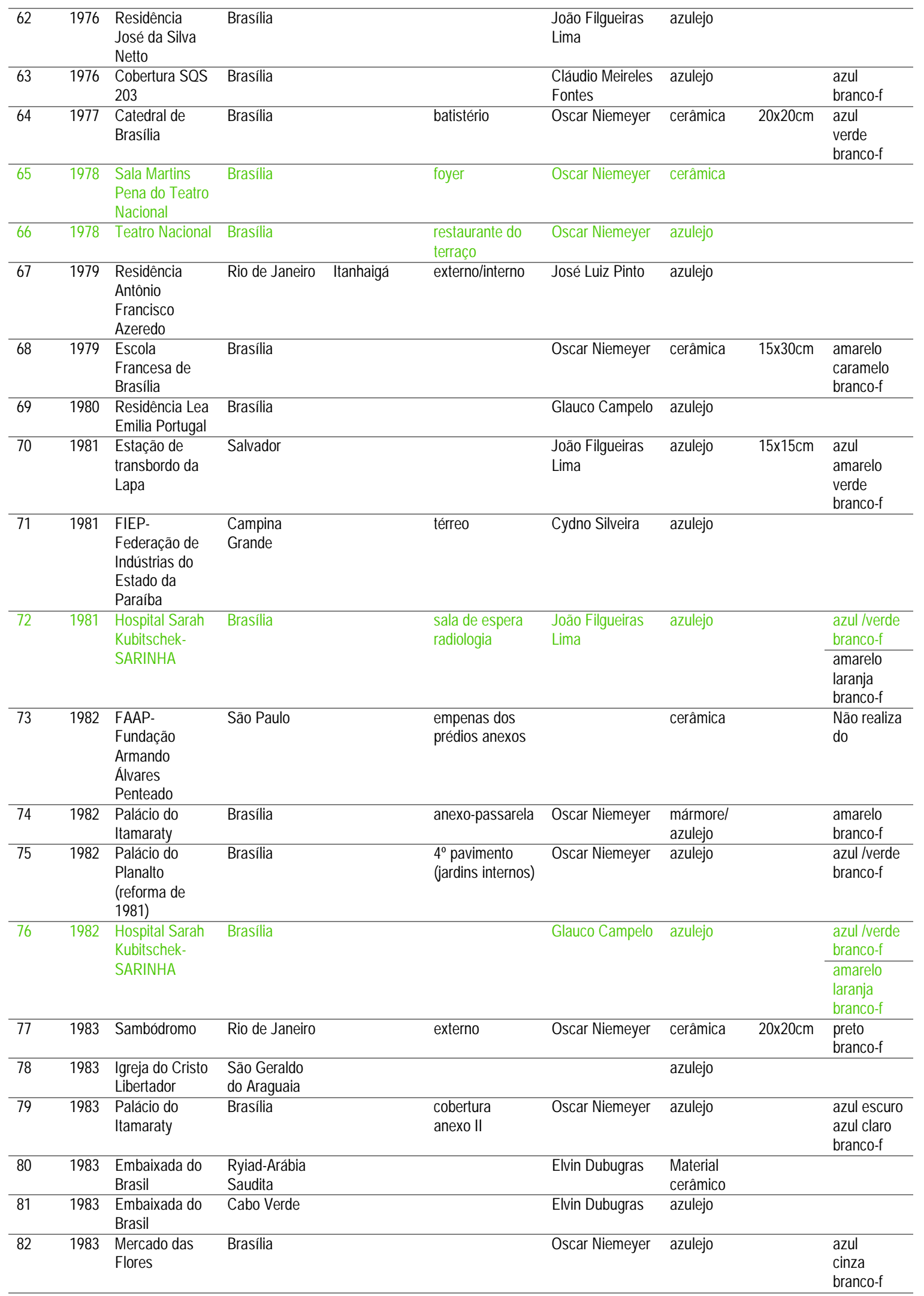




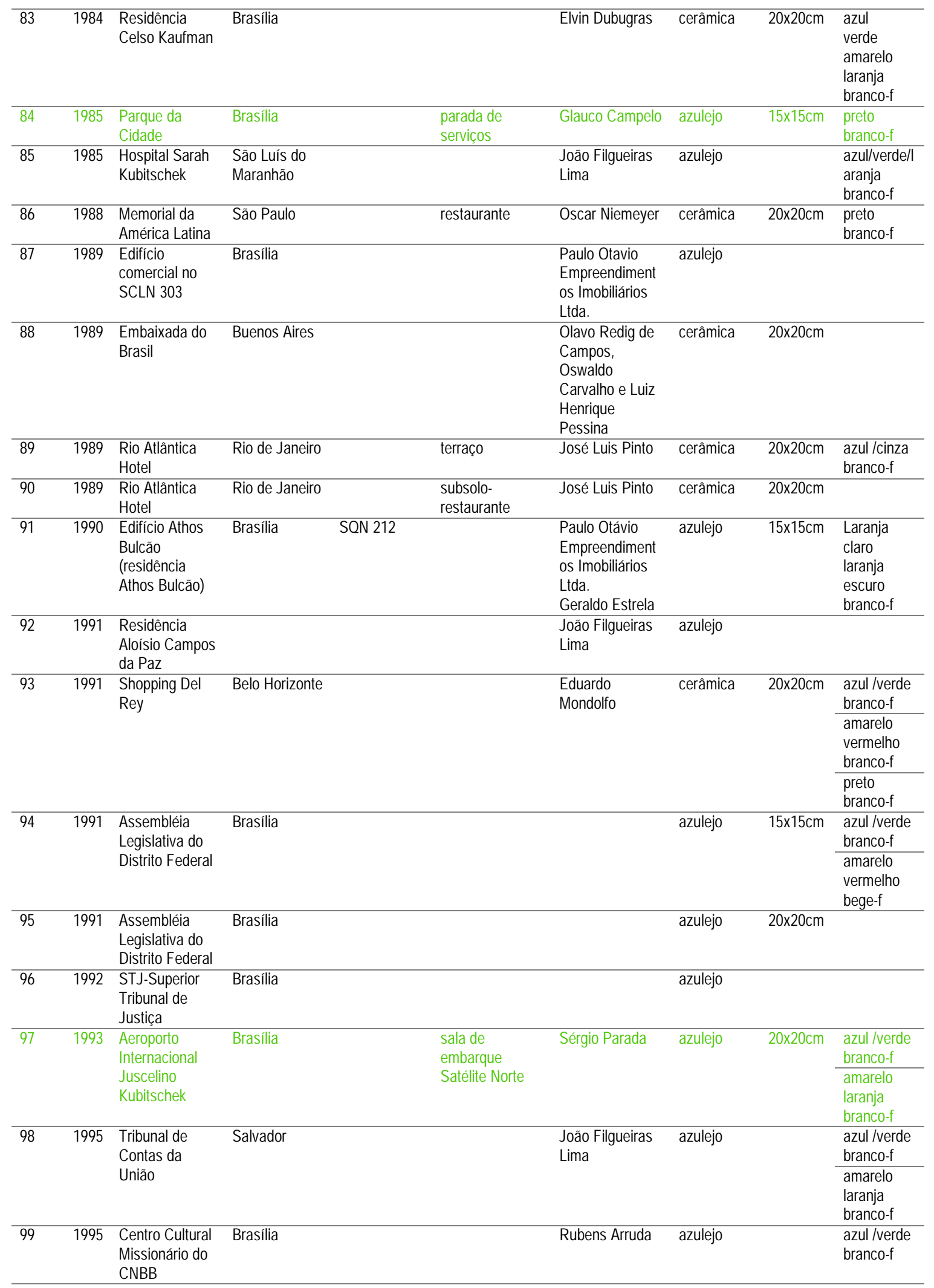




\begin{tabular}{|c|c|c|c|c|c|c|c|}
\hline 100 & 1988 & $\begin{array}{l}\text { Instituto Rio } \\
\text { Branco }\end{array}$ & Brasília & & $\begin{array}{l}\text { Luís Antônio } \\
\text { Reis }\end{array}$ & azulejo & $\begin{array}{l}\text { preto } \\
\text { branco-f }\end{array}$ \\
\hline 101 & 1988 & $\begin{array}{l}\text { Instituto de } \\
\text { Artes da UNB }\end{array}$ & Brasília & & Cláudio Queiroz & azulejo $\quad 20 \times 20 \mathrm{~cm}$ & $\begin{array}{l}\text { azul/verde } \\
\text { branco-f }\end{array}$ \\
\hline \multirow[t]{2}{*}{102} & 1999 & $\begin{array}{l}\text { Residência } \\
\text { Sérgio Parada }\end{array}$ & Brasília & & Sérgio Parada & azulejo & $\begin{array}{l}\text { azul /verde } \\
\text { branco-f }\end{array}$ \\
\hline & & & & & & & $\begin{array}{l}\text { amarelo } \\
\text { laranja } \\
\text { branco-f }\end{array}$ \\
\hline 103 & 1999 & $\begin{array}{l}\text { Universidade } \\
\text { Regional do } \\
\text { Cariri }\end{array}$ & Cariri-CE & & Haroldo Pinheiro & azulejo & \\
\hline 104 & 2000 & $\begin{array}{l}\text { Residência de } \\
\text { Regina Célia } \\
\text { Peres Borges }\end{array}$ & Brasília & & $\begin{array}{l}\text { Luis Antônio } \\
\text { Reis }\end{array}$ & azulejo & \\
\hline 105 & 2001 & $\begin{array}{l}\text { Hospital das } \\
\text { Forças } \\
\text { Armadas }\end{array}$ & Brasília & $\begin{array}{l}\text { INCOR-Inst. do } \\
\text { Coração }\end{array}$ & $\begin{array}{l}\text { Giancarlo } \\
\text { Gregório }\end{array}$ & azulejo & $\begin{array}{l}\text { reforma do } \\
\text { painel }\end{array}$ \\
\hline 106 & 2001 & $\begin{array}{l}\text { Edifício Sede } \\
\text { da Interlegis }\end{array}$ & Brasília & & $\begin{array}{l}\text { Luis Antônio } \\
\text { Reis }\end{array}$ & azulejo & $\begin{array}{l}\text { marrom } \\
\text { amarelo } \\
\text { bege-f }\end{array}$ \\
\hline
\end{tabular}

\section{Observações:}

$f=$ fundo do azulejo.

Os projetos em destaque (com a cor verde) foram detalhados no levantamento iconográfico no

Apêndice 3. 


\section{apêndice 3 \\ levantamento iconográfico}

Brasília

Athos Bulcão
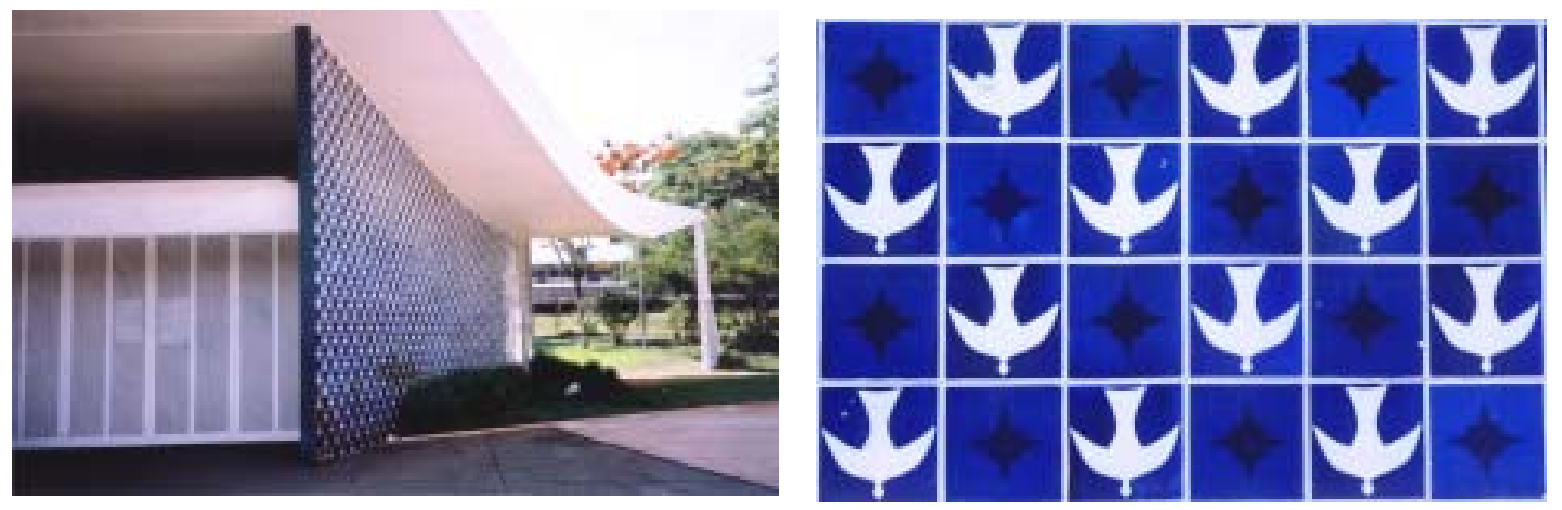

Igrejinha Nossa Senhora de Fátima (1957)

SQS 307/308

Revestimento exterior no térreo

Oscar Niemeyer (arquiteto)

Um dos trabalhos em azulejos mais conhecidos do artista, é um dos primeiros azulejos que desenhou, e também um dos raros exemplos de tema figurativo. A estrela preta sobre fundo azul é uma referência a estrela de Belém, enquanto que a bomba branca do Divino Espírito Santo, representação da paz, posicionada de cabeça para baixo faz alusão ao plano piloto de Brasília. Os dois desenhos contém um friso branco, ressaltando a idéia do azulejo como módulo. 

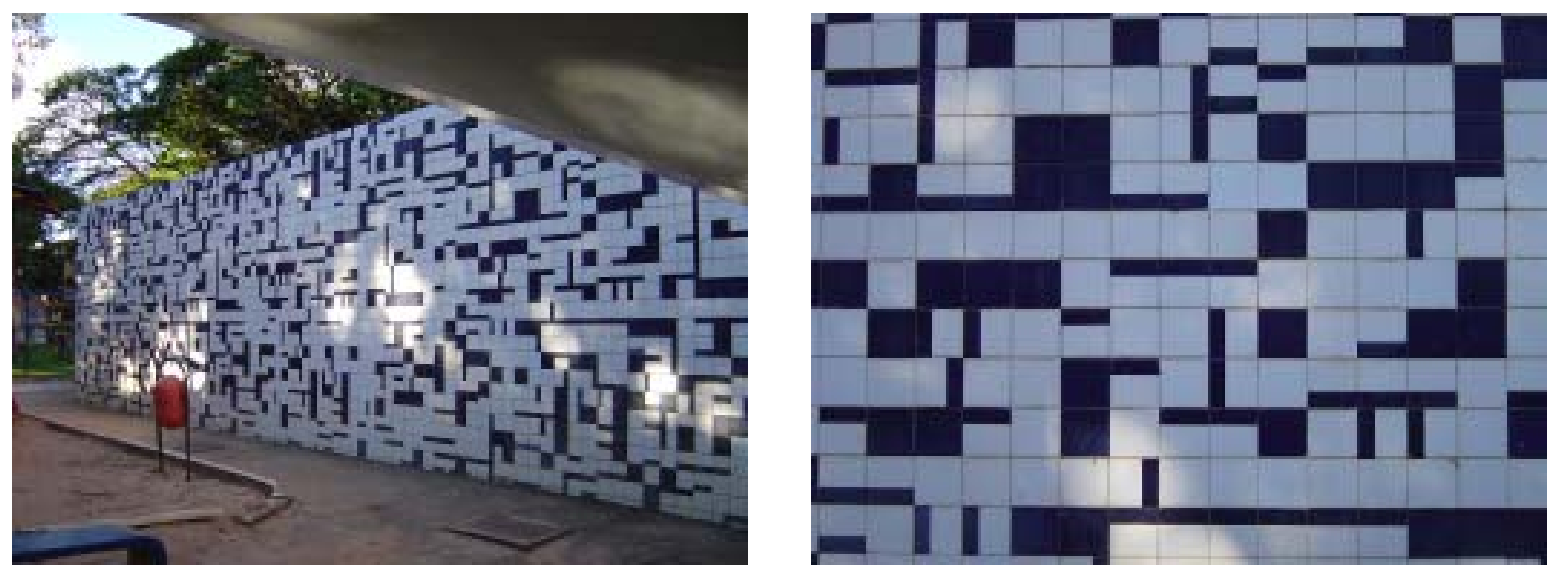

Escola Classe da Entrequadra Norte (1965)

SQN 407/408

Fachadas da entrada principal

Milton Ramos (arquiteto)

Nessa composição são usados três módulos de azulejos $15 \times 15 \mathrm{~cm}$ : um todo branco, um todo preto e o terceiro preto (retângulo ocupando 1/3) e branco (retângulo ocupando 2/3) do azulejo. Disposição aleatória, formando malha irregular em preto e branco. Foi a primeira experiência onde ouve a livre participação do operário na montagem da composição do painel.
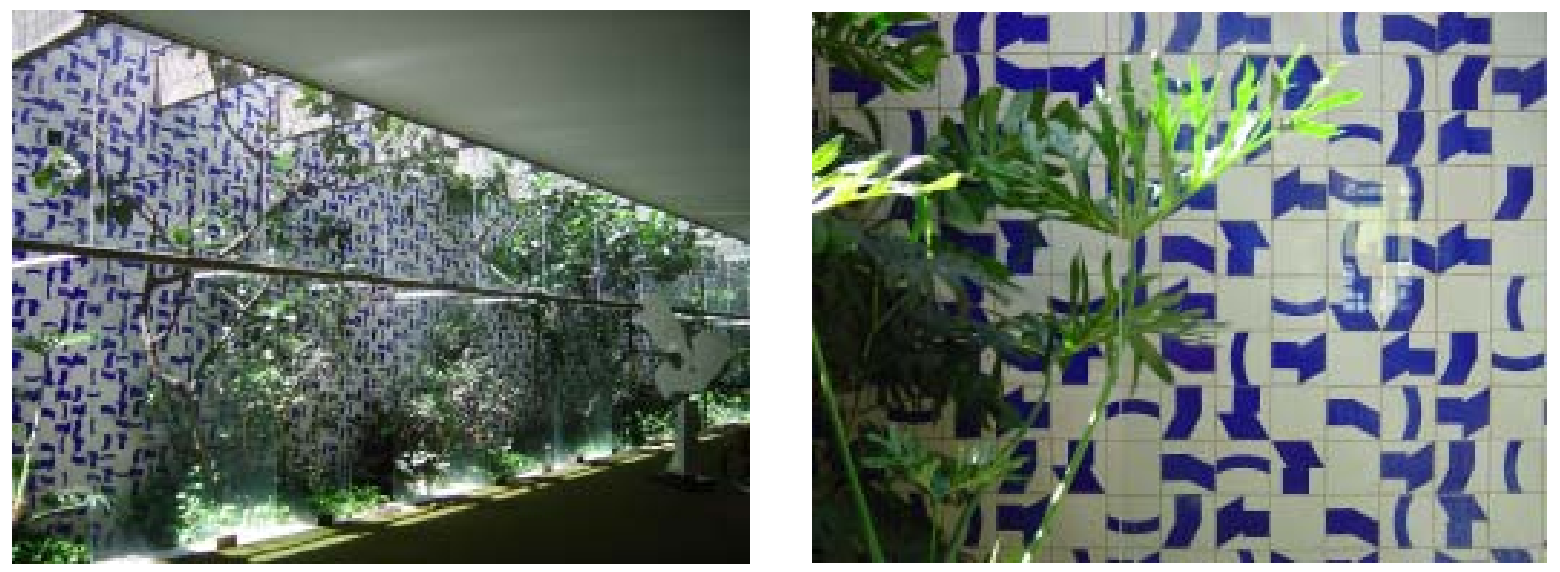

Congresso Nacional (1971)

Praça dos Três Poderes

Jardim interno do Salão Verde da Câmara dos Deputados

Oscar Niemeyer (arquiteto)

Painel de azulejos de $15 \times 15 \mathrm{~cm}$ em quatro módulos diferentes, sendo um sem desenho, todo branco e os outros três com desenhos de figuras geométricas na cor azul sobre fundo branco. 0 painel delimita o jardim interno do Salão Verde, formando um pano de fundo. Esta obra tem 1200 metros quadrados em composição aleatória, onde também teve a participação do operário na montagem do painel. 

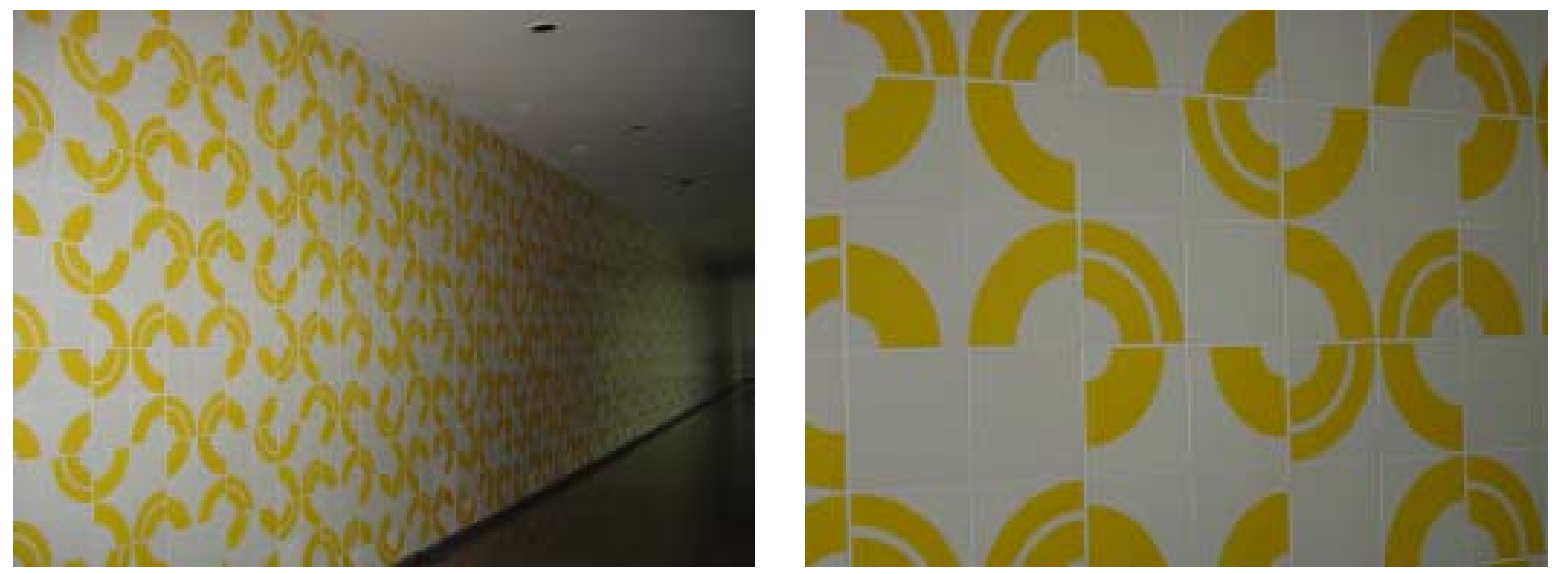

Teatro Nacional Cláudio Santoro (1978)

Setor Cultural Norte

Foyer da Sala Martins Pena

Oscar Niemeyer (arquiteto)

São usados três módulos, sendo um todo branco e os outros com desenho de parte (1/4) de círculo. Na composição são usados arranjos de $4 \times 4$ elementos formando 3/4 de círculos.
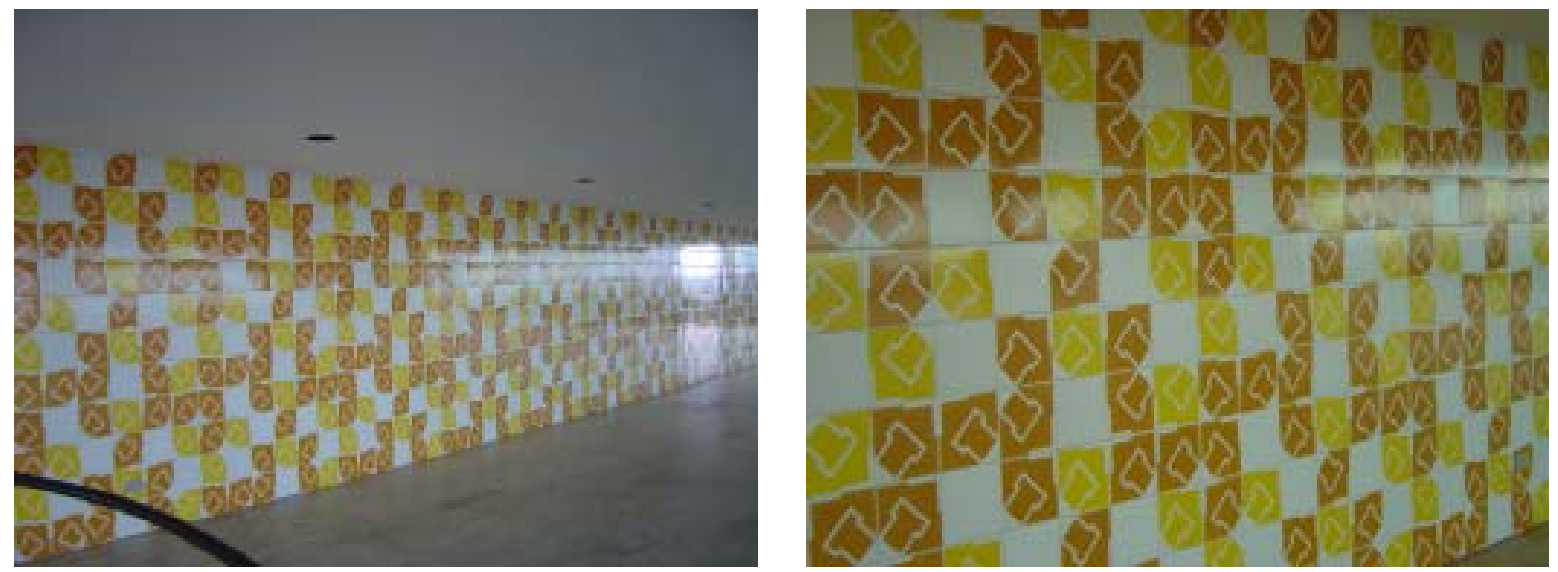

Teatro Nacional Cláudio Santoro (1978)

Setor Cultural Norte

Cobertura / Espaço Dercy Gonçalves

Oscar Niemeyer (arquiteto)

São usados três módulos: um todo branco, os outros dois módulos tem o mesmo desenho, mas em cores diferentes, um laranja e outro amarelo. 


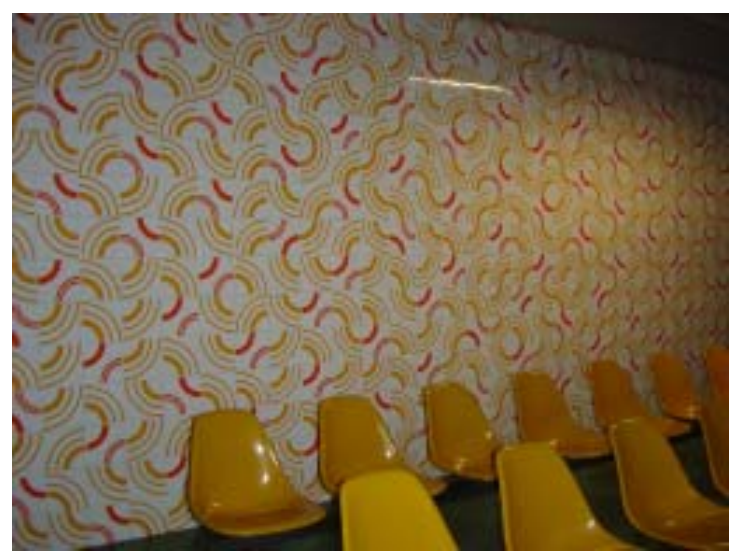

Hospital Sarah Kubitschek-SARINHA (1981)

SMHS quadra 501 bloco $\mathrm{A}$

Sala de espera Radiologia

João Filgueiras Lima (arquiteto)

Dois painéis de azulejos um verde, azul e branco e outro amarelo, laranja e branco. São usados dois módulos diferentes, com desenhos de $1 / 4$ de círculos colocados aleatoriamente, mas de maneira que nunca se fecham.
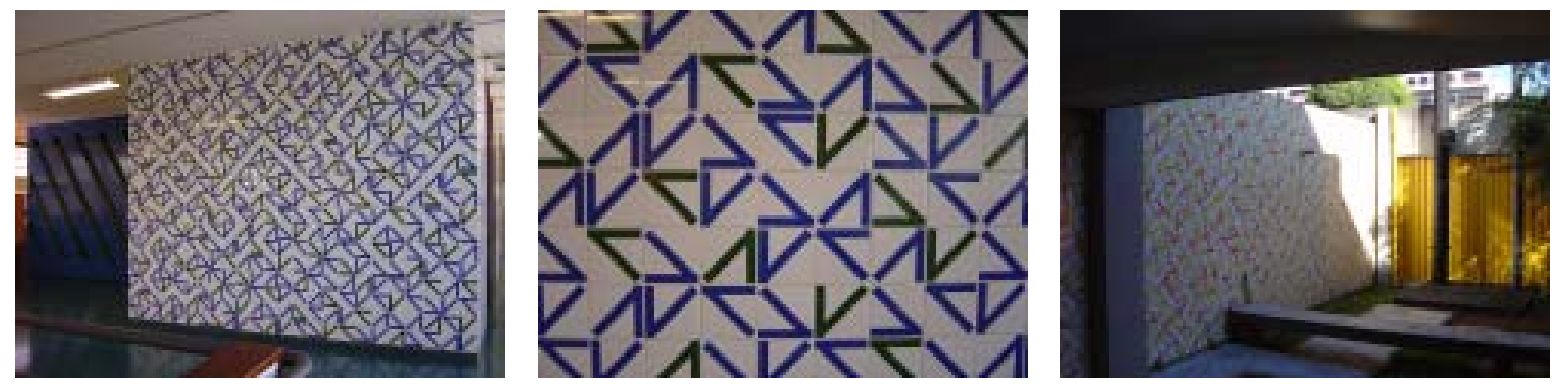

Hospital Sarah Kubitschek-SARINHA (1982)

SMHS quadra 501 bloco $\mathrm{A}$

Revestimento de paredes de corredores internos e muro externo

Glauco Campelo (arquiteto)

Dois painéis de azulejos um verde, azul e branco e outro amarelo, laranja e branco. É usado apenas um módulo com desenho que parece uma metade de seta.
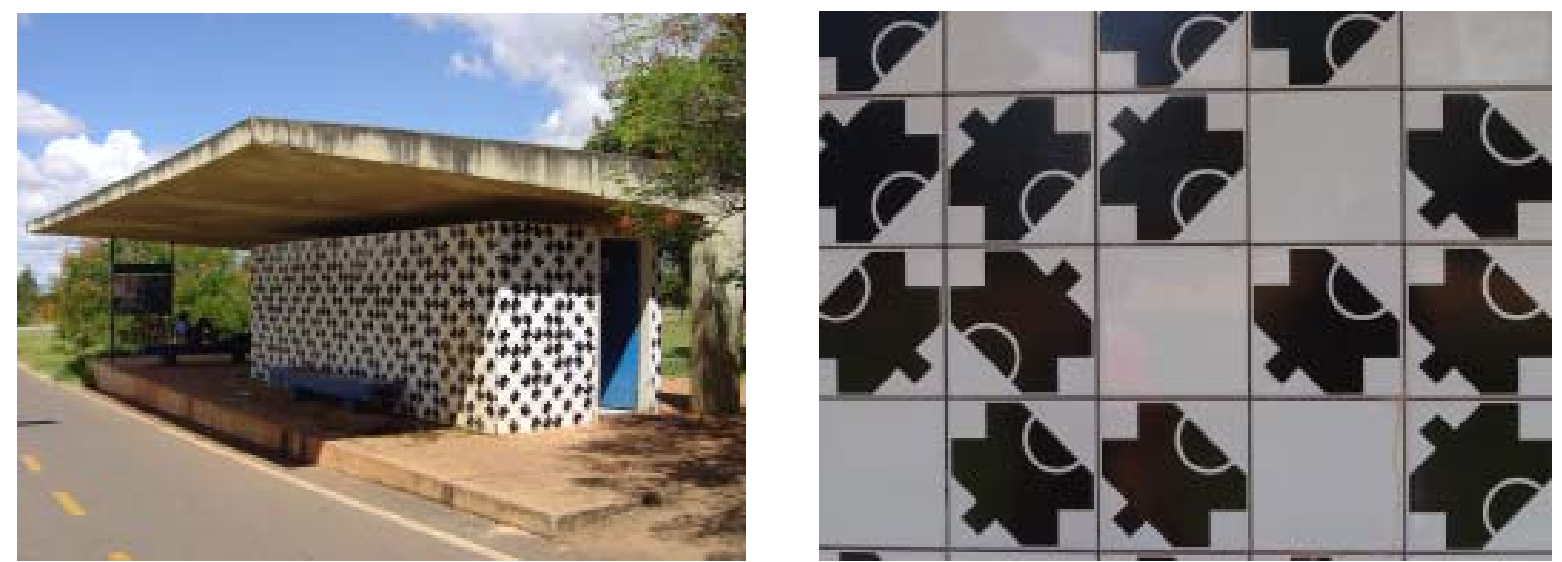

Parque da Cidade (1985)

Parada de serviços

Glauco Campelo (arquiteto)

São usados dois módulos, um todo branco e outro com desenho em preto sobre fundo branco. Composição aleatória, onde o desenho é colocado em qualquer posição. 

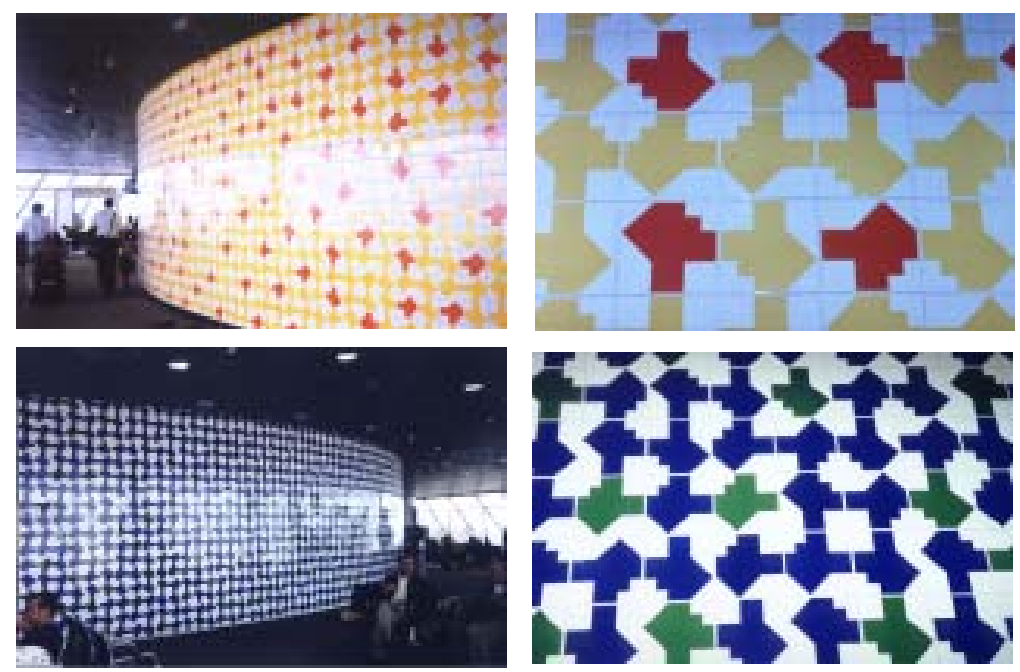

Aeroporto Internacional Juscelino Kubitschek (1993)

Sala de embarque Satélite Norte

Sérgio Parada (arquiteto)

Dois painéis de azulejos um verde, azul e branco e outro amarelo, laranja e branco. É usado apenas um módulo colocado em qualquer das 4 direções. Em um painel existe mais concentração do módulo na cor azul, pontuado com os módulos na cor verde. No outro existe mais concentração de amarelo, pontuado com laranja. Segundo o próprio Athos o desenho geométrico parece uma seta, que dá uma certa direção.
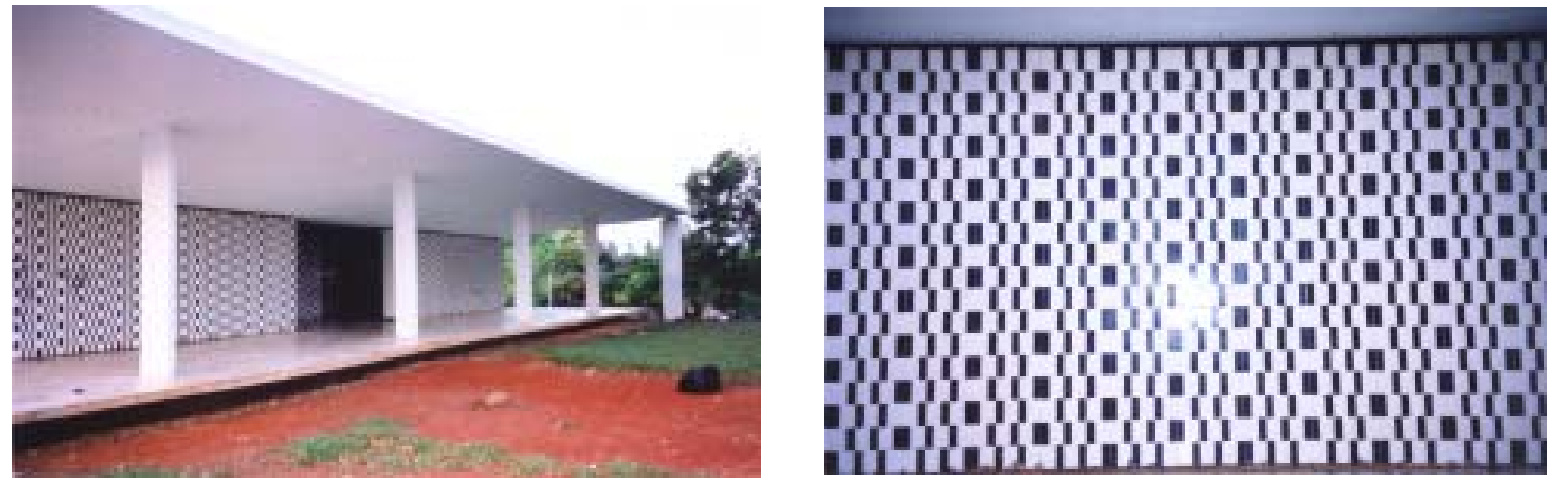

Escola de Educação

Campus UnB

Revestimento de paredes dos terraços

É usado apenas um módulo: um retângulo preto que ocupa 1/3 do azulejo de fundo branco, 0 retângulo preto é posicionado sempre na vertical ( 3 vezes do lado direito, 3 vezes do lado esquerdo para formar a carreira horizontal de azulejos). 

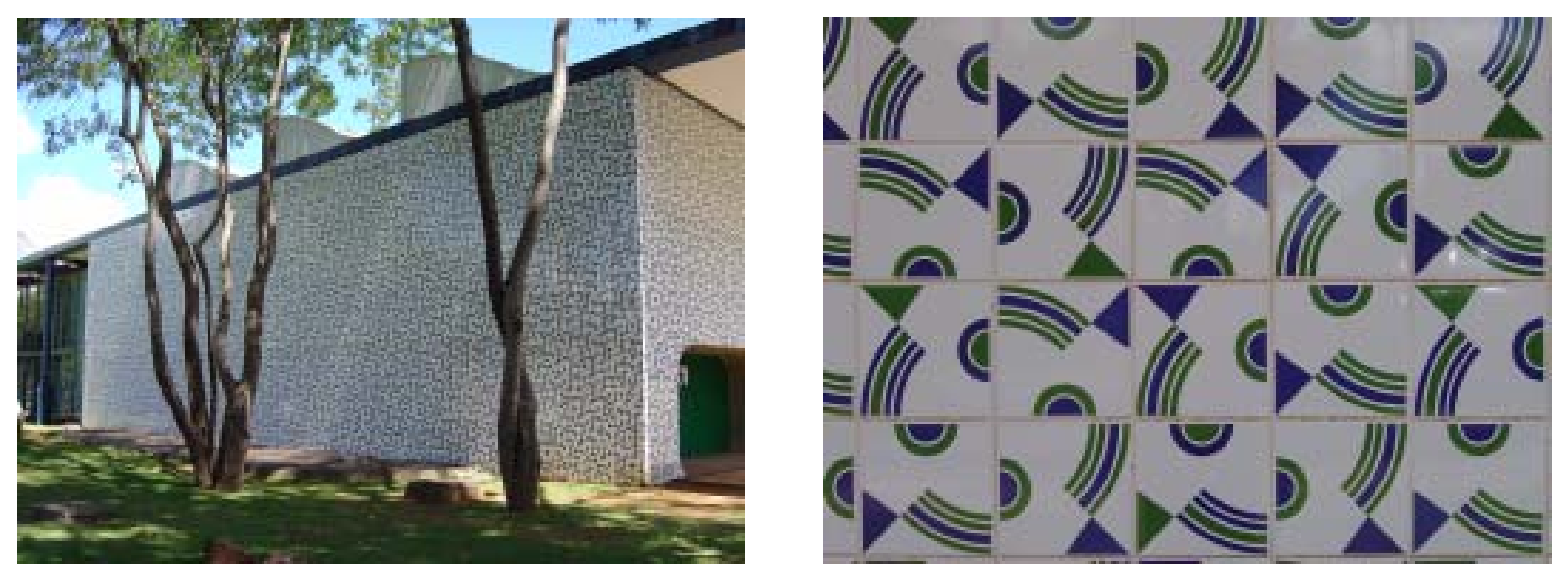

Instituto de Artes da UNB (1998)

Campus da UnB

Paredes/revestimento externo

Cláudio Queiroz (arquiteto)

É usado apenas um desenho, que formam dois módulos (de azulejos 20×20cm) pela alternância das cores azul e verde sobre fundo branco.
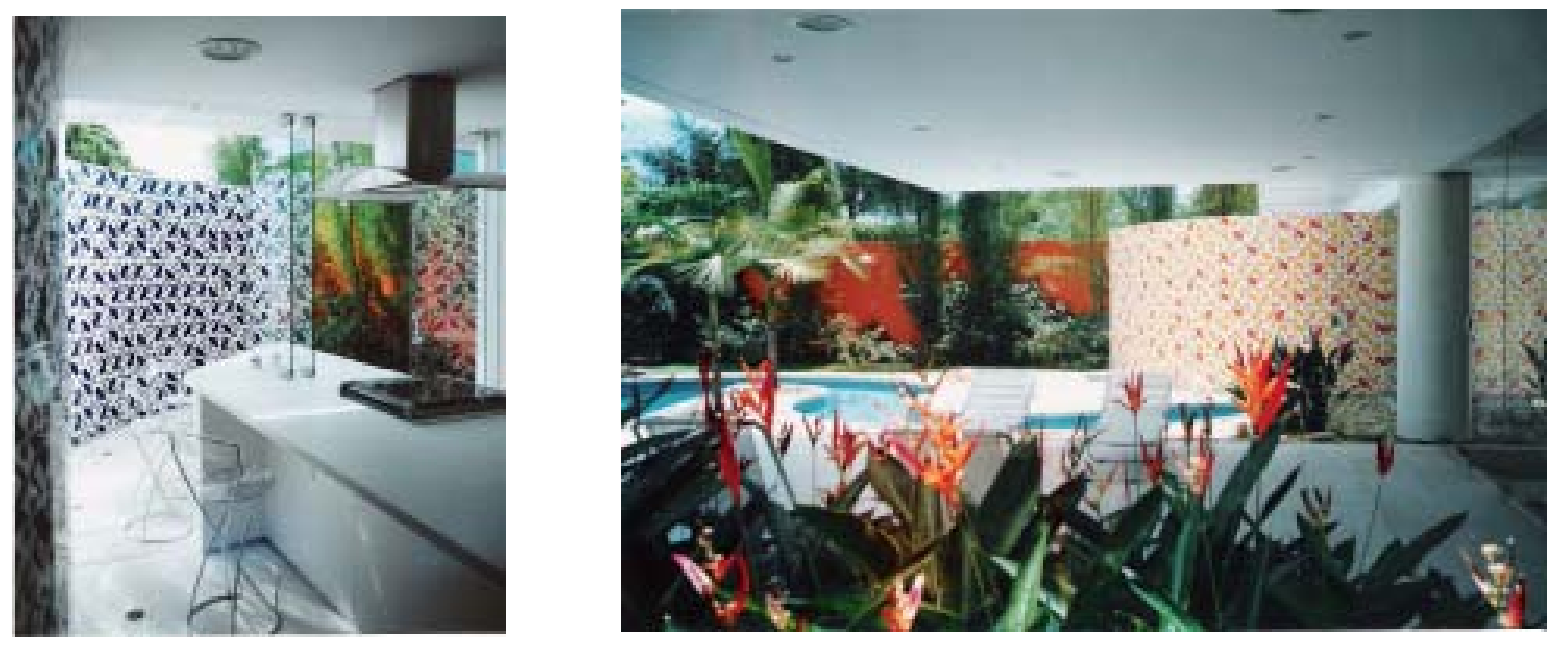

Residência Sérgio Parada (1999)

Muro interno e externo

Sérgio Parada (arquiteto)

Dois painéis de azulejos: um verde, azul e branco (um módulo) e outro amarelo, laranja e branco (dois módulos). O desenho dos módulos é o mesmo, variando as cores. O muro tem um formato sinuoso em S, que percorre partes internas da casa (cozinha) e partes externas (jardins e piscina). 


\section{Recife}

\section{Delfim Amorim}
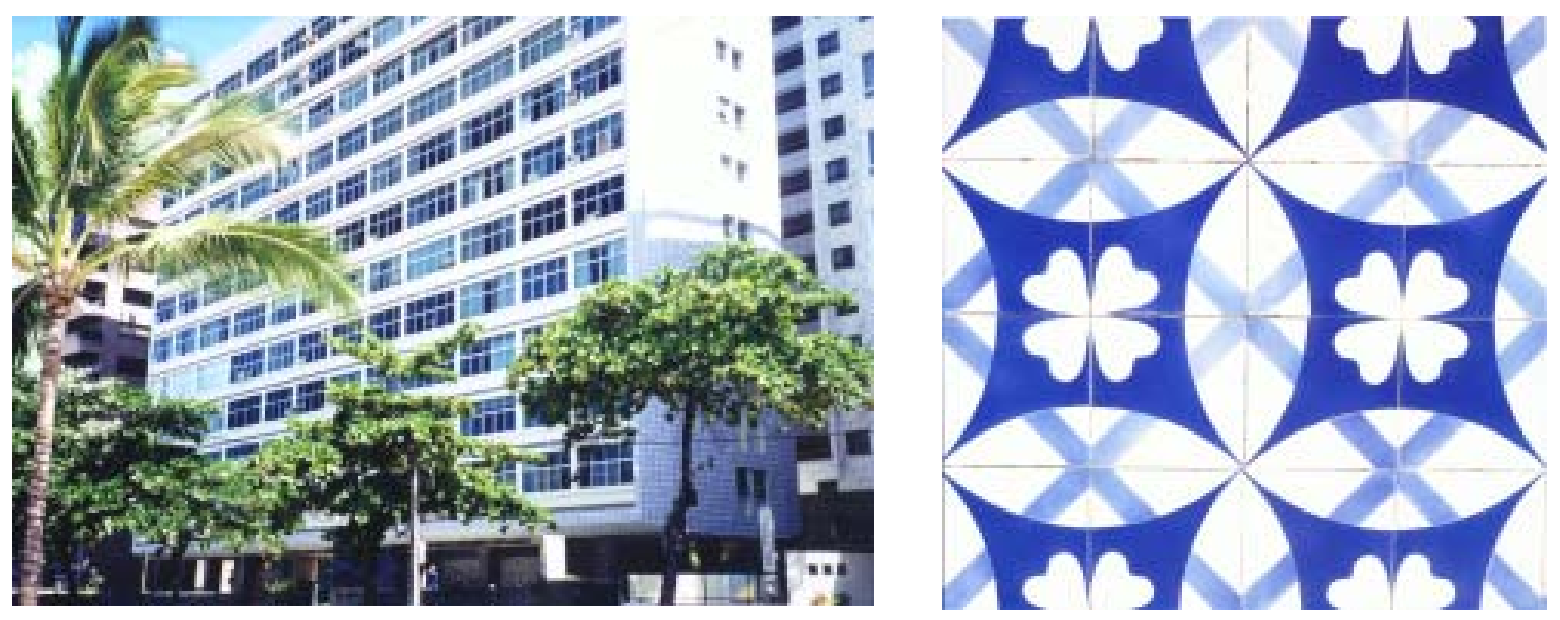

Edifício Acaiaca (1957)

Av. Boa Viagem, 3232

Fachadas laterais e moldura da fachada nascente

Delfim Fernades Amorim e Lúcio Estelita (arquitetos)

Um dos primeiros edifícios para afins residenciais construídos naAvenida Boa Viagem. As fachadas laterais são levemente chanfradas, revestidas de azulejos que continuam na fachada nascente formando molduras. $O$ edifício se destaca por ser uma lâmina paralela à avenida, disposição rara atualmente devido ao preço alto dos terrenos a beira-mar. É usado apenas um desenho ou módulo nas cores azul claro e azul escuro sobre fundo branco. Um primeiro motivo se forma com a aplicação de 4 (2x2) azulejos, outro motivo completa esse primeiro na aplicação de $16(4 \times 4)$ azulejos. Essa aplicação remete aos azulejos de padrão usados na época colonial. Ao longe se nota a soma cromática e a curta distância é que se vê o motivo do azulejo.

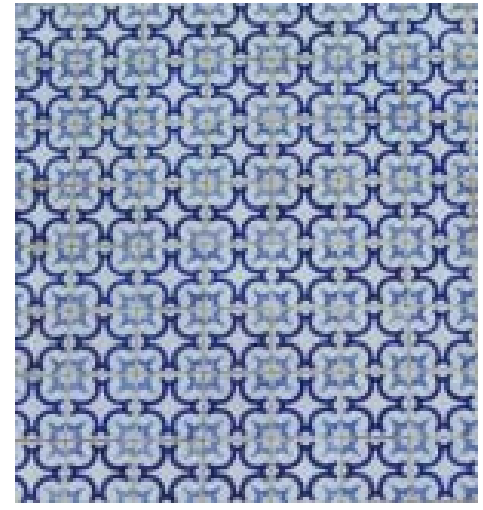

Edifício Araguaia (1961)

Av. Governador de Lima Cavalcanti, 241

Fachadas

Delfim Fernades Amorim (arquiteto)

Edifício para fins residenciais compõe-se de pilotis, para estacionamento de veículos e mais três pavimentos. As duas fachadas que recebem maior insolação são quase totalmente revestidas com azulejos. É usado apenas um desenho ou módulo nas cores azul claro e azul escuro sobre fundo branco. 0 motivo se forma com a aplicação de 4 (2x2) azulejos, como os azulejos de padrão. 

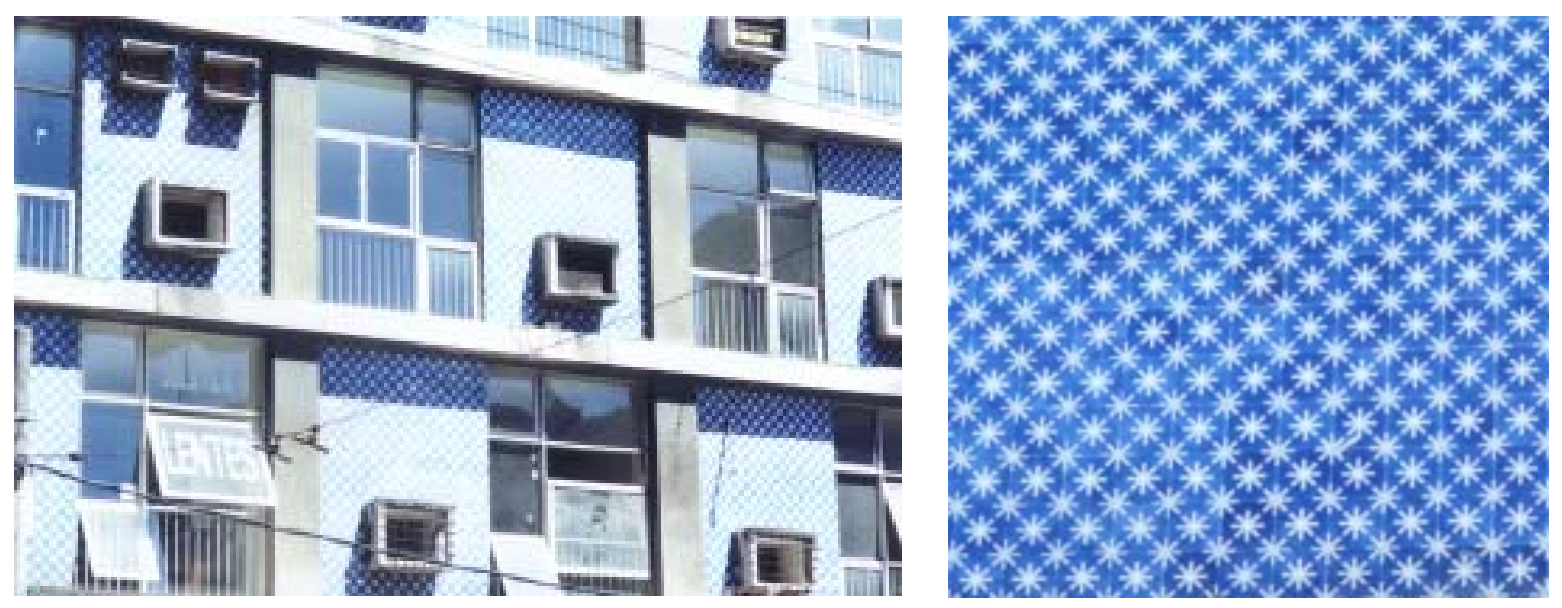

Edifício Santa Rita (1962)

Av. Conde da Boa Vista, 85

Fachadas

Delfim Fernades Amorim (arquiteto)

Prédio para fins comerciais no pavimento térreo e primeiros pavimentos superiores e residenciais nos demais pavimentos. Nas duas frentes externas desenvolve-se jogo plástico, pela alternância de paredes cobertas de azulejos com as saliências (pequenas caixas pré-moldadas em concreto armado) que abrigam os aparelhos de ar-condicionado, se tornam elementos característicos dessa tendência do arquiteto. Em outra fachada se combinam elementos vazados de cerâmica (cobogós) com paredes de azulejos. Ouve uma simplificação de motivo nesse azulejo. O módulo é formado por um asterisco no meio da peça e três astes de asteriscos nos 4 cantos da peça. 0 asterisco é branco sobre fundo azul, nesse caso o fundo azul é que foi pintado.
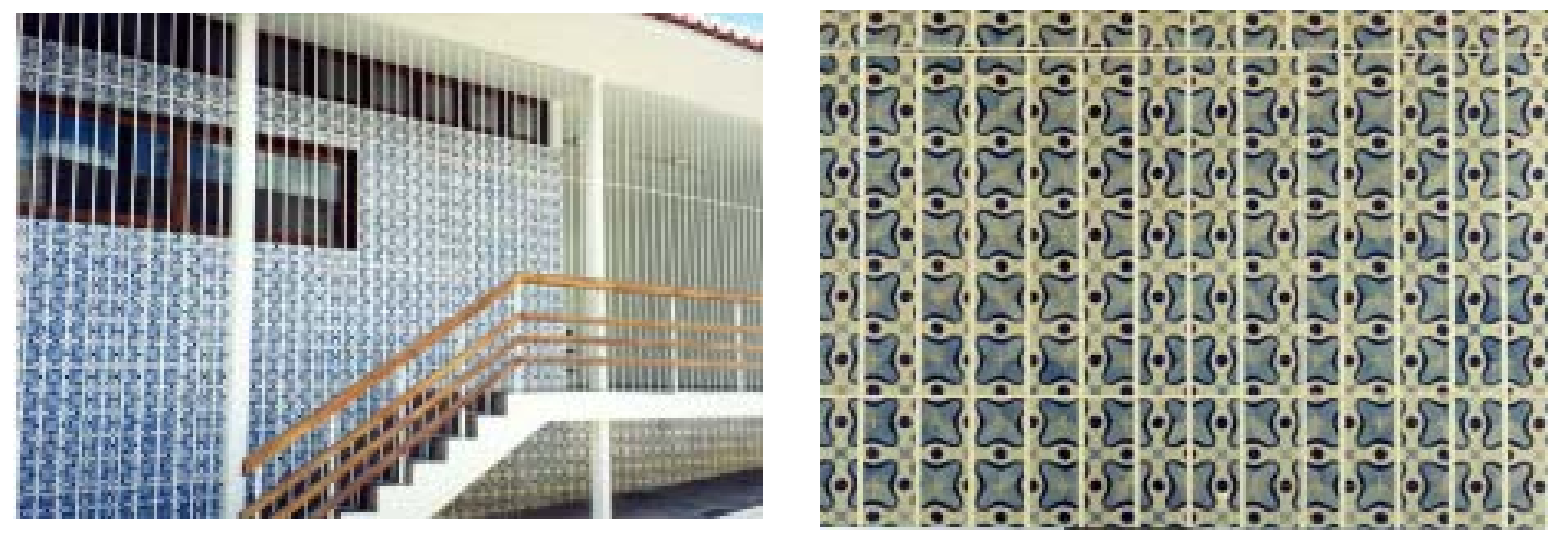

Residência Wilson Porciúncula (1964)

Rua Hermógenes de Morais, 284

Parede frontal

Delfim Fernades Amorim (arquiteto)

A parede frontal da casa é quase totalmente revestida de azulejo em duas tonalidades de azul (azul claro e azul escuro) sobre fundo branco, onde o motivo básico é formado com a aplicação de quatro peças. 

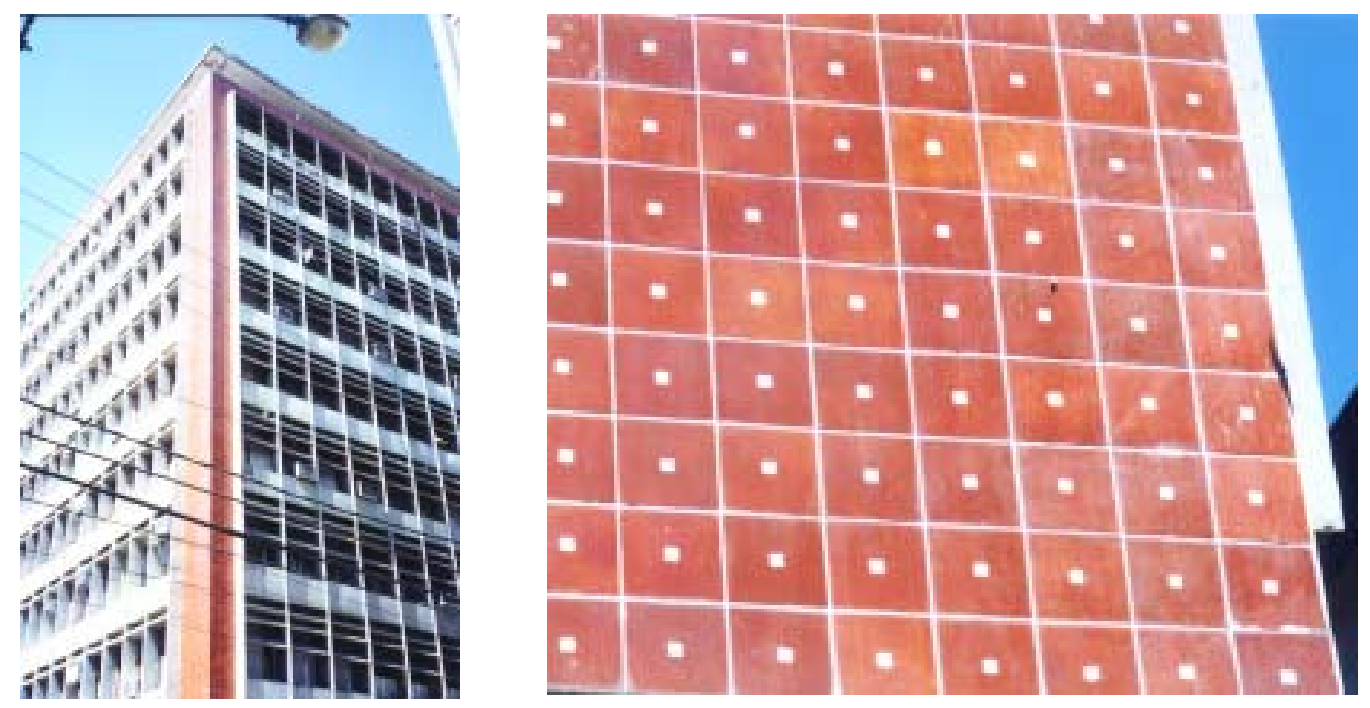

Edifício Independência (1965)

Rua Sete de Setembro, 42

Molduras de 2 fachadas

Delfim Fernandes Amorim, Heitor Maria Neto Arquitetos Associados (arquitetos)

Edifício para fins comerciais, pavimento térreo ocupado por lojas e demais pavimentos por escritórios. Tem as fachadas executadas por elementos pré-fabricados de concreto armado, dispostos horizontal e verticalmente. O conjunto das duas fachadas é emoldurado por barras verticais e horizontais de azulejos. O motivo é geométrico, um pequeno quadrado vazado branco no meio da peça, de cor marrom (os únicos encontrados nessa cor).
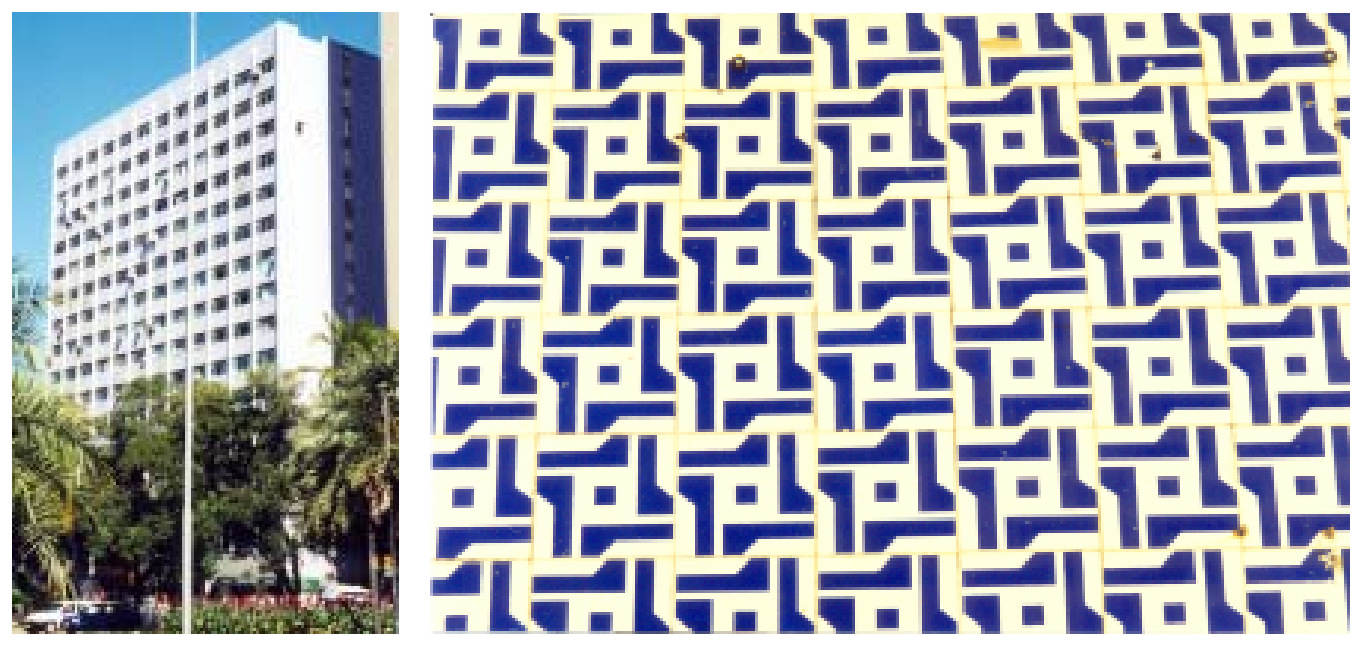

Edifício Marcílio Dias/Almirante Barroso (1967)

Endereço: Rua do Riachuelo, 201/189

Fachadas

Delfim Fernandes Amorim e Cláudio Marinho Cavalcanti (arquitetos)

Edifício para fins residenciais e escritórios. As duas fachadas são quase totalmente revestidas de azulejos. O motivo é um módulo geométrico em azul escuro sobre fundo branco, que só é percebido a curta distância. 


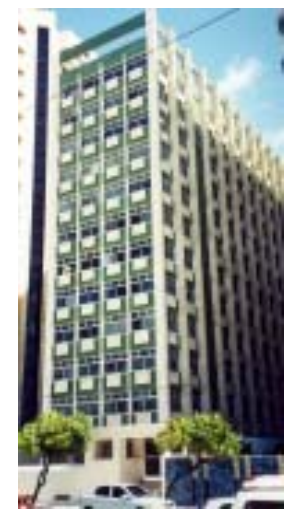

Edifício Francisco Vita (1968)

Av. Boa Viagem, 3040

Fachadas

Delfim Fernandes Amorim e Heitor Mais Neto (arquitetos)

Edifício residencial. Curiosamente neste edifício as fachadas foram revestidas com azulejos verde escuro, com relevo e de linha industrial, provavelmente azulejos da IASA - Indústria de Azulejos S.A. Embaixo das janelas foram colocados elementos retangulares préfabricados, formando jogo geométrico de relevos. Nota-se a substituição de alguns azulejos da fachada em tonalidade diferente do original, e sem relevo. Essa substituição de azulejos só é percebida à curta distância.
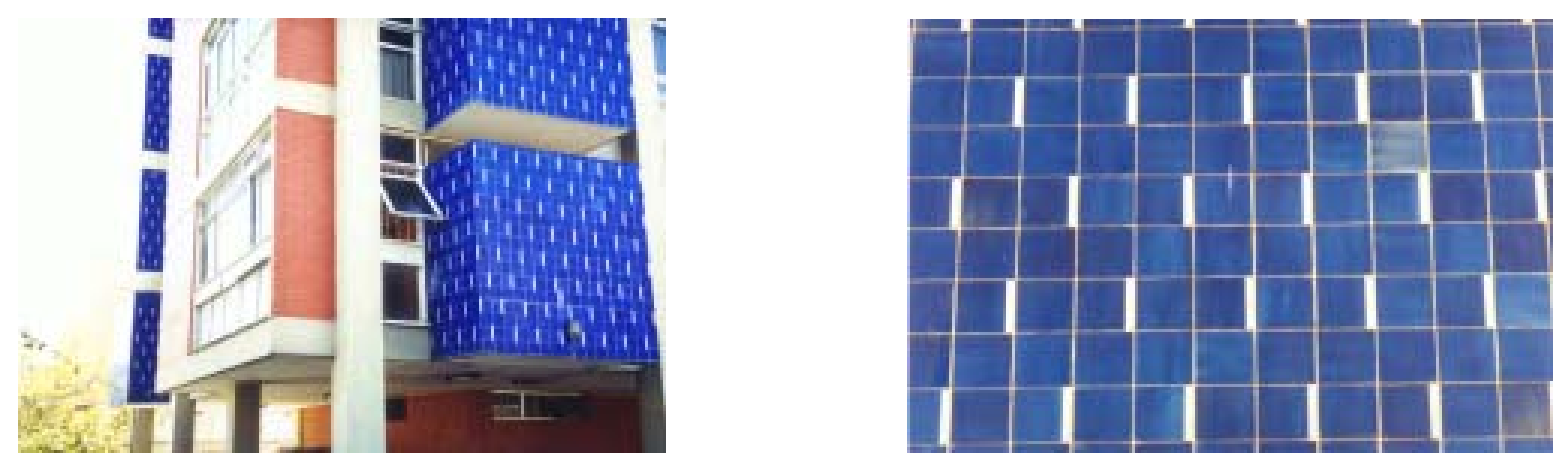

Edifício Barão do Rio Branco (1969)

Rua do Giriquiti, 205

Fachadas (revestimento das caixas dos guarda-roupas e varandas)

Delfim Fernandes Amorim e Heitor Mais Neto Arquitetos Associados (arquitetos)

Edifício para fins residenciais de um apartamento por andar. Subsolo destinado a garagem, cobertura do subsolo destinada a play-ground e acesso principal do edifício. Esse edifício foi a primeira tentativa, no Recife, de desconstrução da forma de prisma exigida pelo código de obras da Municipalidade do Recife. Os guarda-roupas dos quartos projetam-se para fora dinamizando as fachadas. Fachadas envidradas do piso ao teto intercaladas de panos de tijolos á vista ou closets revestidos de azulejos. O motivo do azulejo já bem simplificado, apenas alguns azulejos possuem retângulo branco em fundo pintado azul, são aplicados em conjunto com azulejos de fundo totalmente azul.

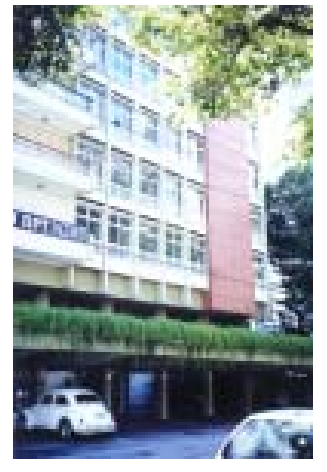

148
Edifício Duque de Bragança (1970)

Rua Miguel Couto, 89

Fachada

Delfim Fernandes Amorim (arquiteto)

Edifício para fins residenciais de um apartamento por andar. O pavimento térreo destinase ao estacionamento de veículos e o pavimento vazado, superior ao térreo é o playground. Os peitoris em concreto armado são revestidos de azulejos originalmente na cor marrom clara, hoje substituído por azulejos brancos com listras pretas verticais, provavelmente de linha industrial e não exclusivos. 


\section{Recife}

Petrônio Cunha
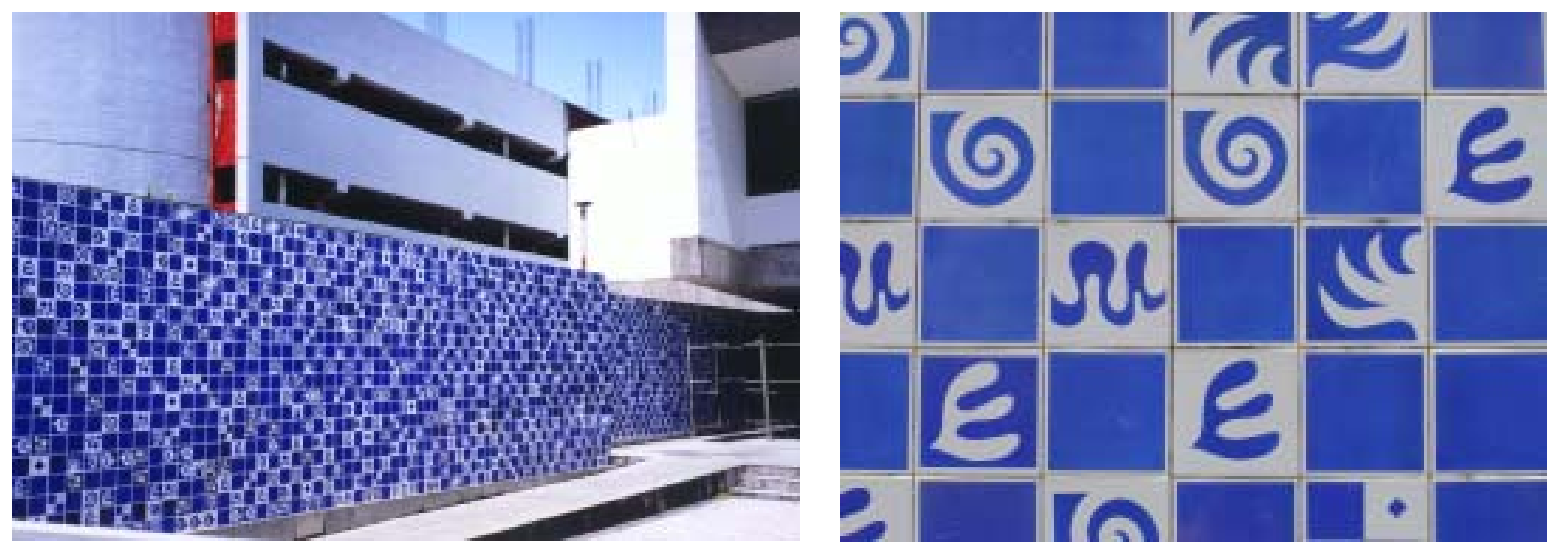

Agência Caixa Econômica Federal

Av. Dantas Barreto

Muro externo e parede interna

Carlos Fernando Pontual e Gerônimo da Cunha Lima (arquitetos)

Foram usados dez ou doze padrões diferentes na cor azul com fundo branco desenvolvendo uma linguagem visual que lembra os trabalhos de Athos Bulcão, como o uso de duas cores, a alusão ao carnaval, com os desenhos que parecem serpentinas e confetes e a disposição aleatória. O painel reveste o muro externo e continua na parede da parte interna da agência.
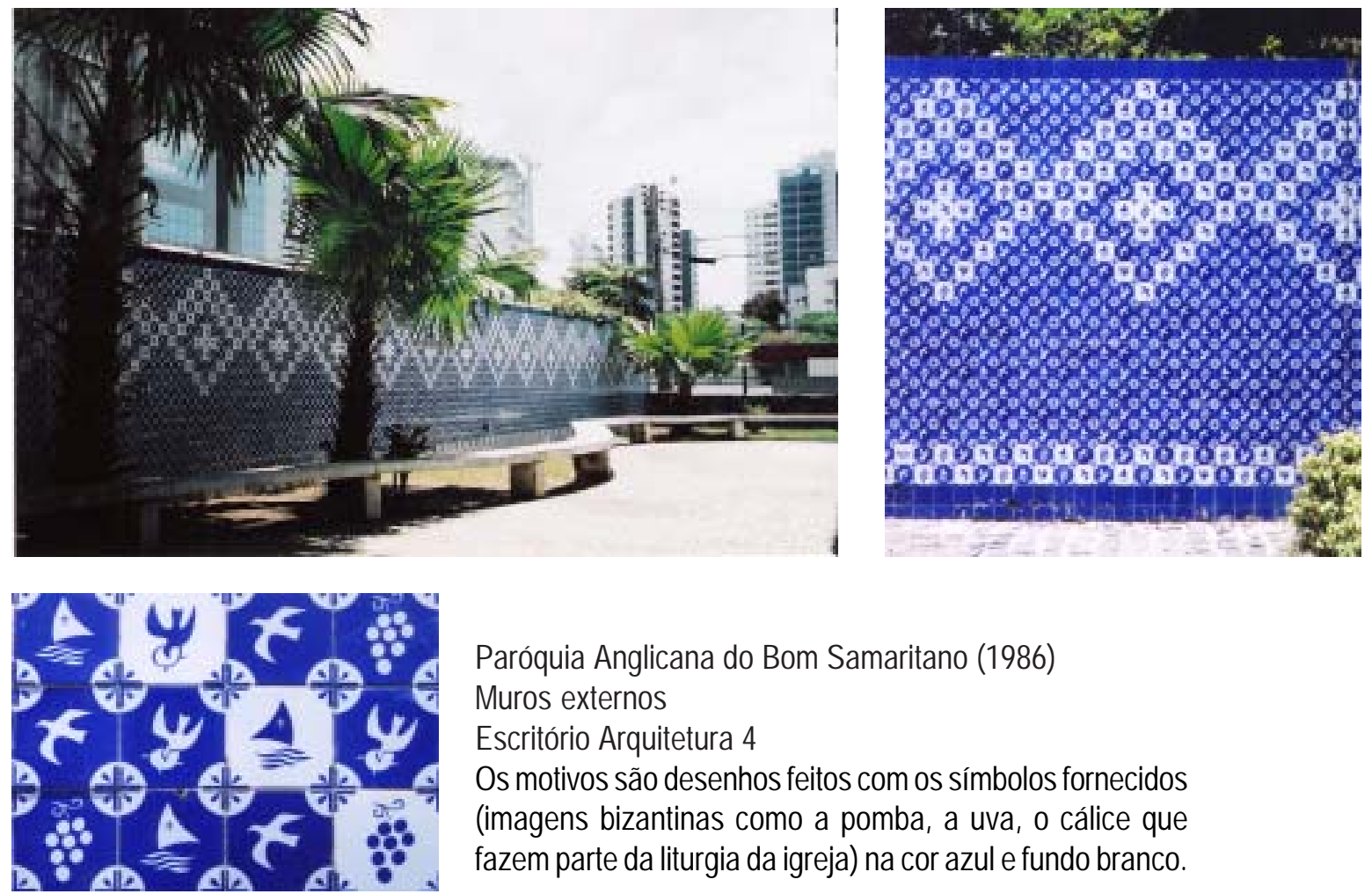

Paróquia Anglicana do Bom Samaritano (1986)

Muros externos

Escritório Arquitetura 4

Os motivos são desenhos feitos com os símbolos fornecidos (imagens bizantinas como a pomba, a uva, o cálice que fazem parte da liturgia da igreja) na cor azul e fundo branco. 
Apenas de perto se vê os motivos dos módulos, a medida que a visão do espectador se afasta, ou vistos de longe os muros parecem superfícies rendadas. Alusão a princípio usado por Delfim Amorim nos diferentes pontos de percepção, curta, media e longa distância.
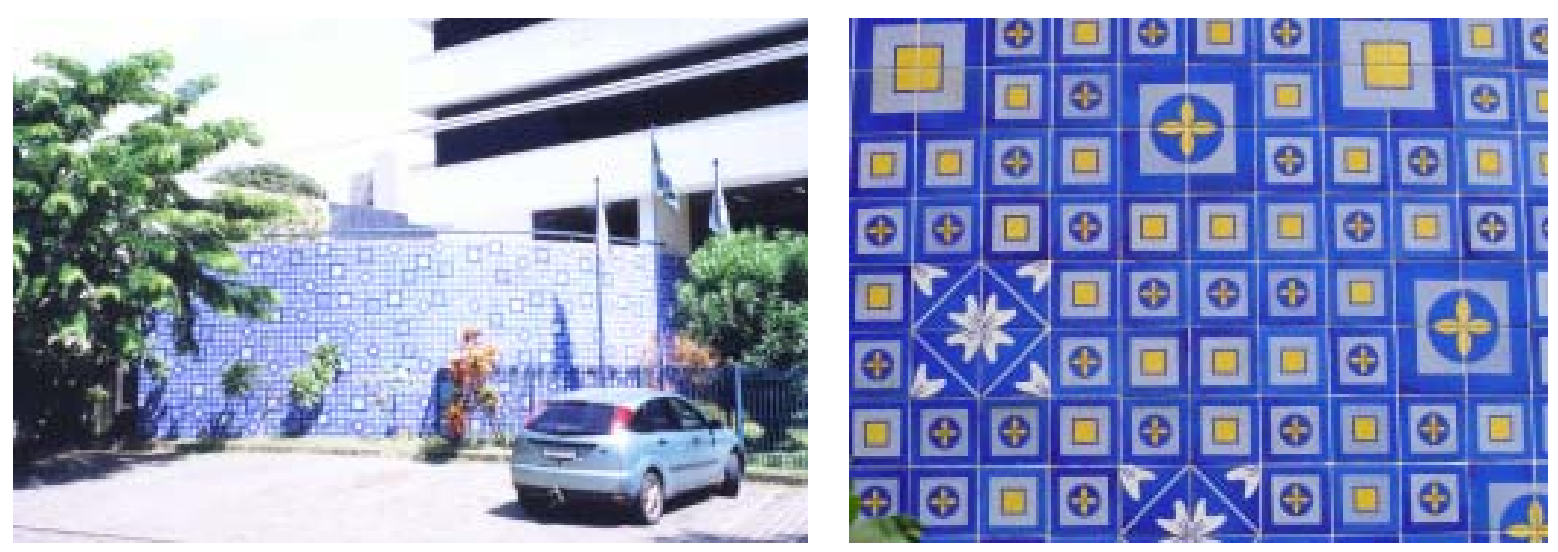

Tribunal de Contas da União (1995)

Santo Amaro

Muro externo e torre na parte de cima e atrás do prédio

Antônio Amaral, Clara Charifker, Ana Amélia Oliveira e Tânia Schuambach (arquitetos)

Para essa composição houve um estudo matemático específico. A composição feita com elementos pequenos ( 2 módulos diferentes), onde cada azulejo forma um desenho, e elementos grandes (3 motivos diferentes), que são formados com a junção de quatro azulejos (2×2). 0 artista definiu um princípio de aplicação onde em cada módulo de 10×10, por exemplo, teriam que conter os três elementos grandes e os pequenos, mas não definiu a posição dos elementos. Essa disposição ficou a cargo do operário ou mestre de obra que instalou os azulejos. Resultando, assim, numa composição aleatória, princípio que remete a alguns projetos de Athos Bulcão.
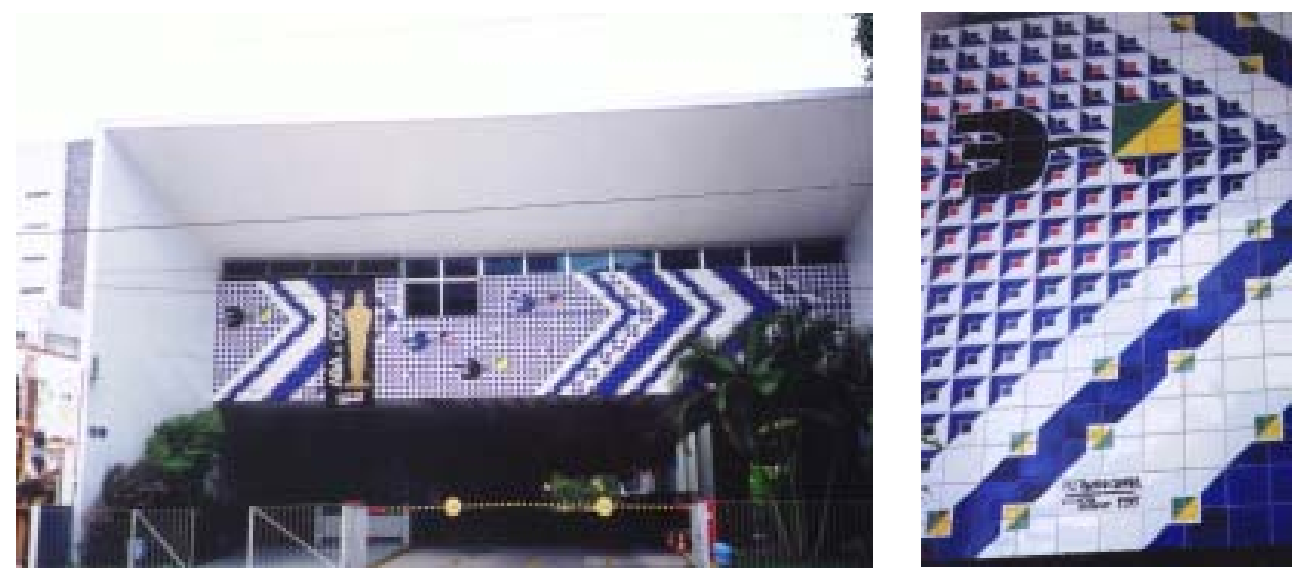

Associação Brasil América (1997)

Av. Rosa e Silva, 1510

Fachadas e paredes de algumas salas internas 
Composição feita por módulos pequenos misturados com desenhos grandes, nas cores das bandeiras do Brasil e dos Estados Unidos. Optou por desenhos geométricos misturados com figurativos representados por pombas e bandeiras, apenas de perto se vê os detalhes do painel.

\section{Rio de Janeiro}
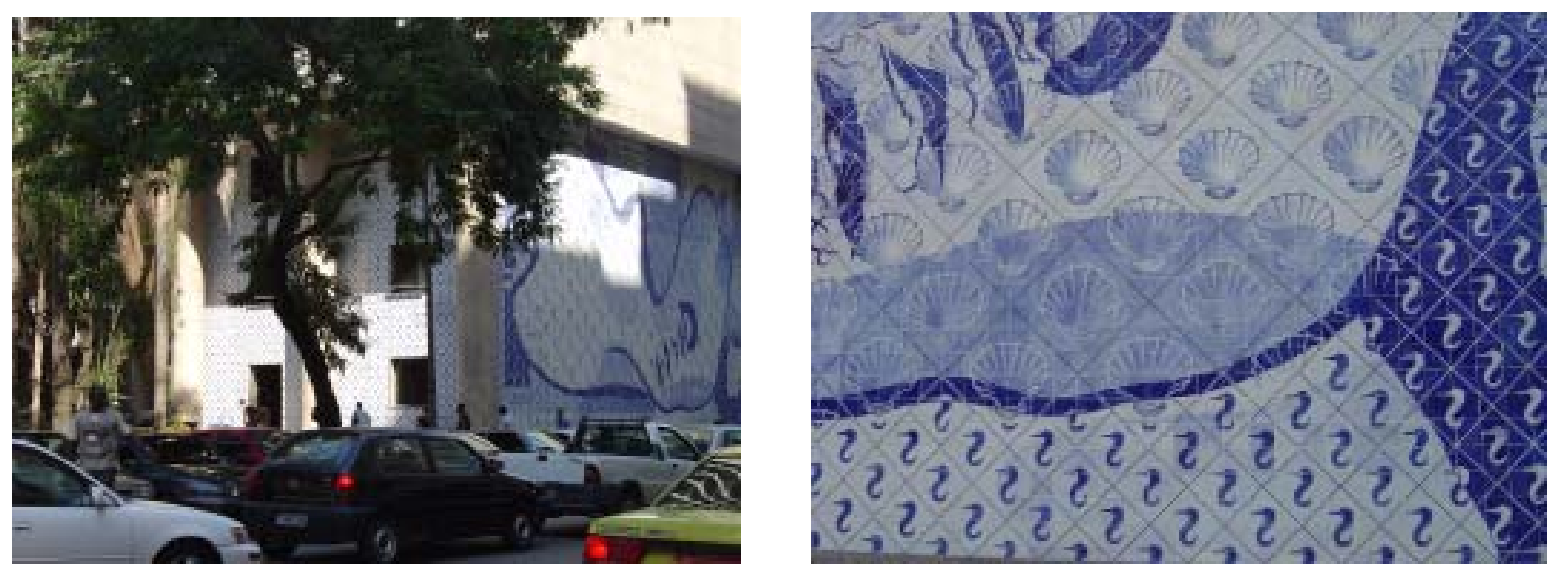

Ministério da Educação e Saúde (1945)

Cinco paredes do térreo

Lúcio Costa, Afonfo Reidy, J. Morreira, C. Leão, Eduardo Vasconcelos e Oscar Niemeyer (arquitetos)

Cinco painéis localizados no térreo, sobre o pilotis. Dois painéis são de Portinari e três são de Paulo Rosi Osir. Todos os painéis são composições em tons de azul sobre fundo branco, com temas marinhos como estrelas do mar, caranguejos, peixes, conchas, sereias, cavalos-marinhos.

\section{Belo Horizonte}
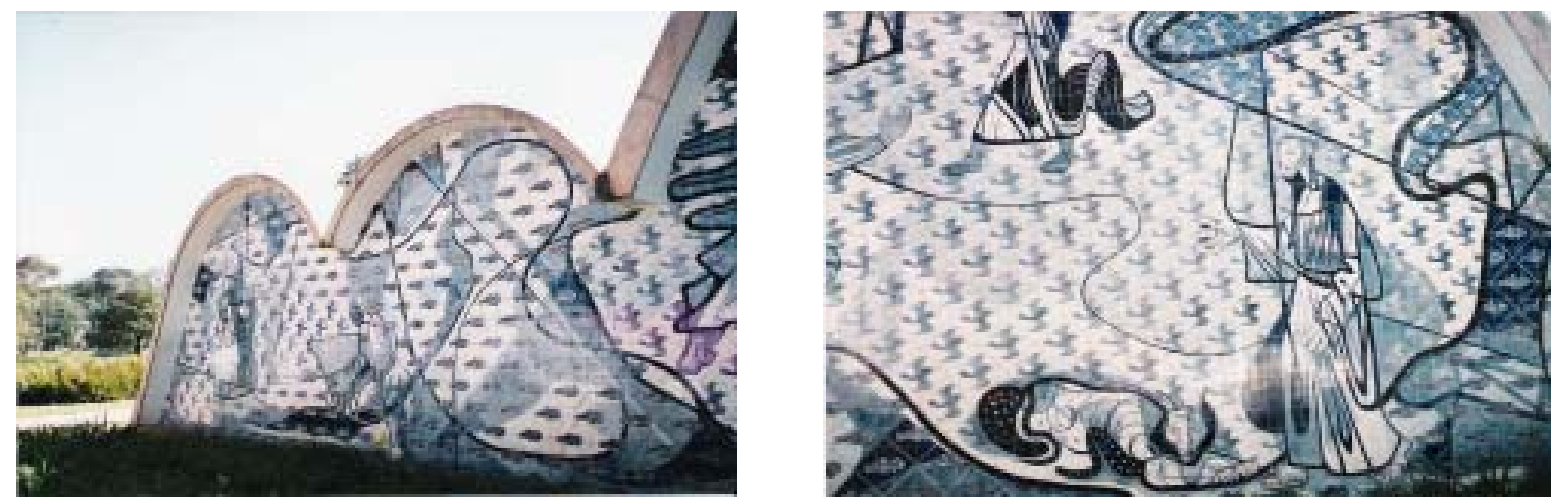

Igreja São Francisco de Assis

Pampulha

Fachada 
Oscar Niemeyer (arquiteto)

Painel de Portinari que retrata a vida de São Francisco de Assis, linguagem figurada e de forte expressão, em tons de azul sobre fundo branco.

\section{Aritiba}
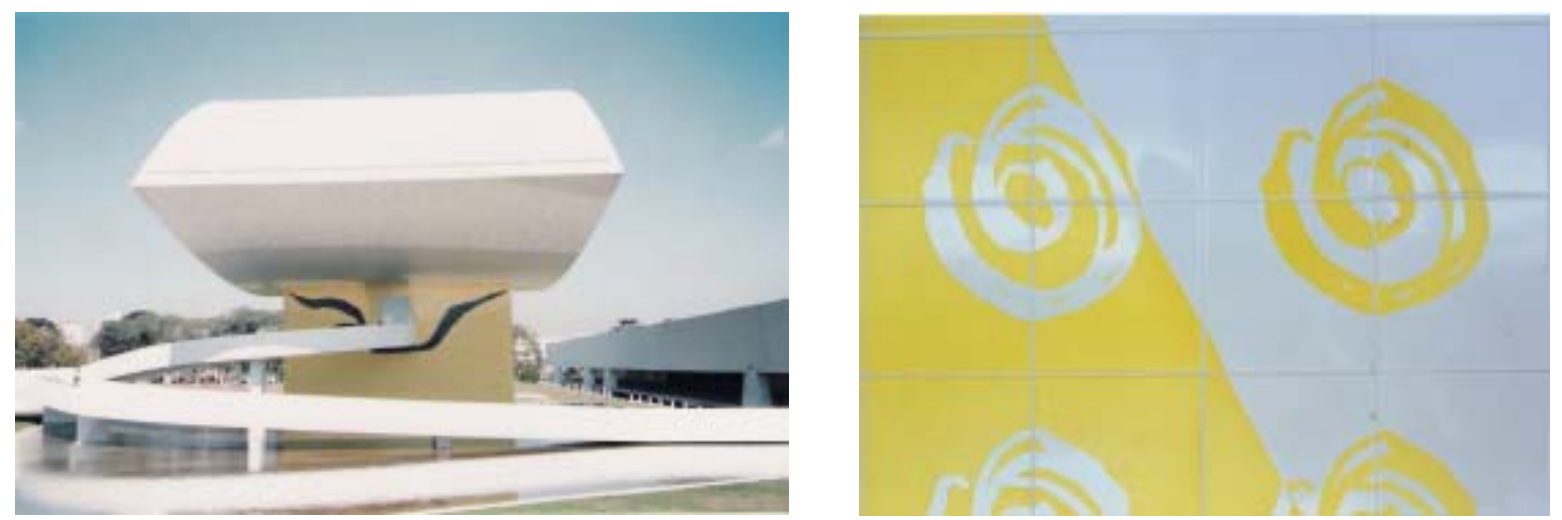

Edifício Castelo Branco e Novo Museu (2002)

Painel na parede do térreo do Edifício Castelo Branco e revestimento externo do prisma do Novo Museu

Oscar Niemeyer e escritório Brasil Arquitetura (arquitetos)

No térreo do edifício, Castelo Branco encontram-se dois painéis de azulejos na cor amarela com fundo branco. São grafismos em forma de um espiral que compõem um jogo de positivo e negativo, sendo cada espiral inserido em quatro azulejos. O painel foi executado em 2002, por Maria Helena Saporiti e Elvo Benito Demo. No Novo Museu, as paredes maiores do prisma retangular, estrutura central que suporta a parte superior em forma de olho, receberam enormes grafismos pretos que lembram folhagens. Todo prisma é revestido com azulejos amarelo vivo. Em uma das paredes menores da lateral do prisma aparece um grafismo com uma silhueta de mulata.

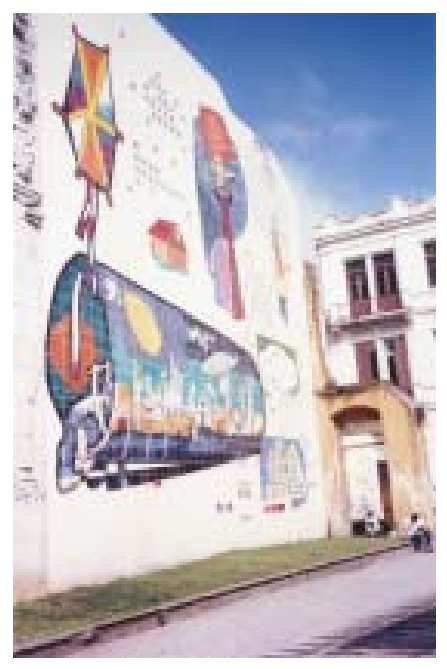

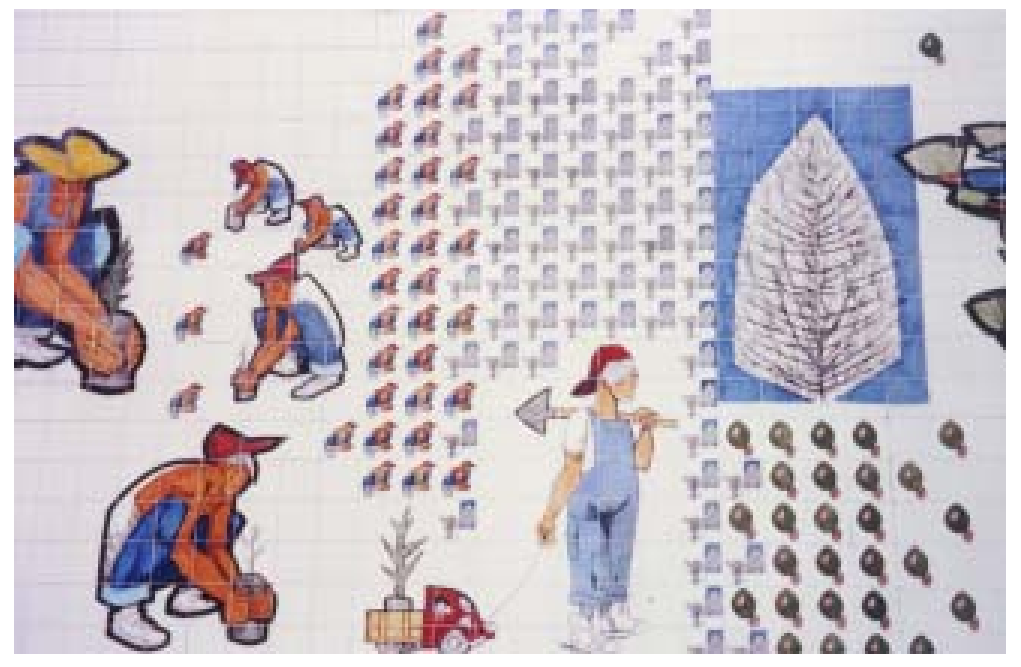

azulejo na arquitetura brasileira: os painéis de athos bulcão 
Murais de Poty Lazzarotto (1996)

Largo da Ordem, centro de Curitiba

Painel figurativo e linguagem narrativa que mostra riquezas, atividades e peculiaridades da região.

\section{São Paulo}
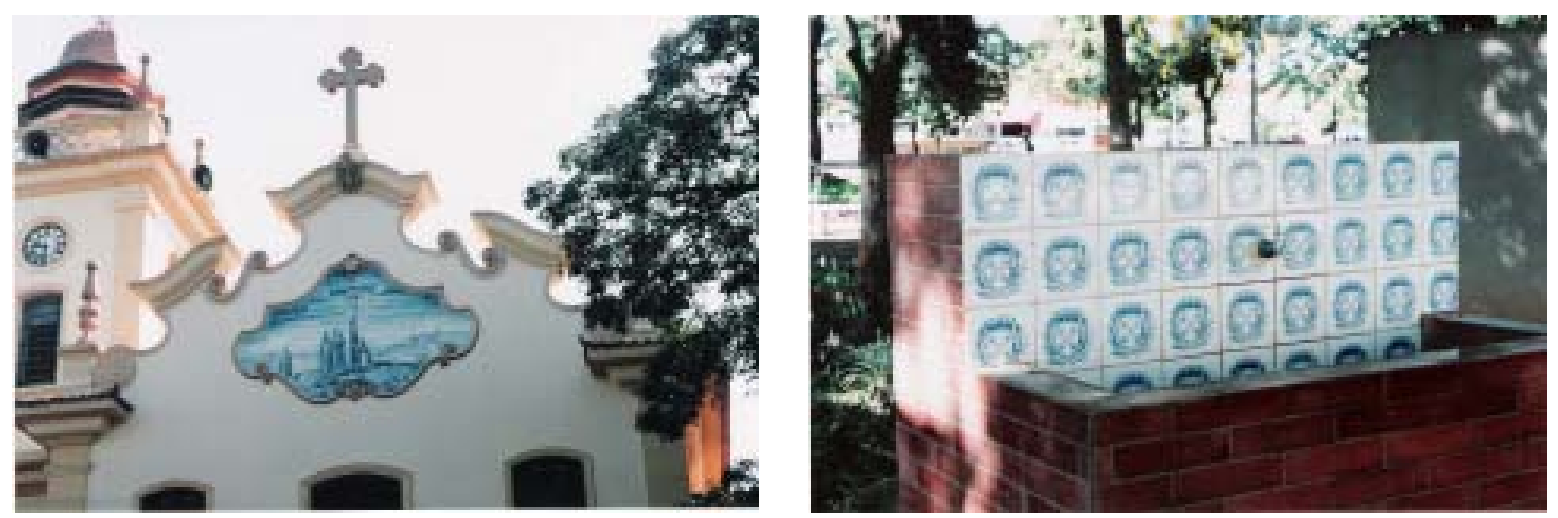

Igreja Jesus Crucificado

Iracemápolis

Fachada e pias na praça

No frontão da fachada principal da Igreja tem um painel com composição figurativa em azul e branco. As pias com torneiras que ficam na praça em frente a Igreja são revestidas com azulejos que contêm o desenho do escudo ou brasão da cidade em azul sobre fundo branco, o que lembra o brasão da cidade de São Paulo no Largo da Memória.

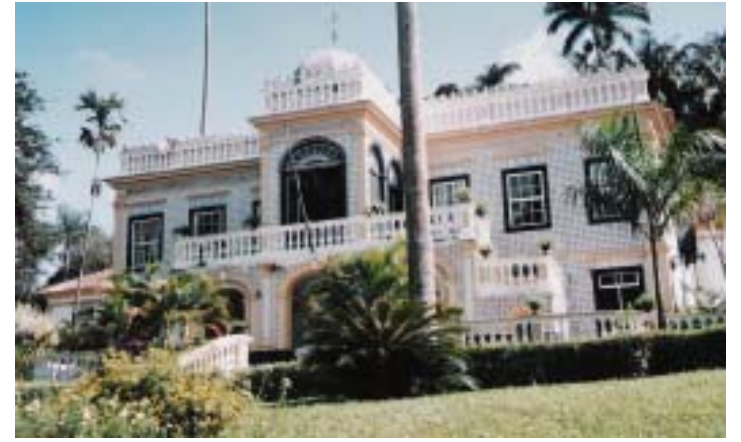

Sede da Fazenda Morro Azul (1868/1877)

Rodovia Limeira, Iracemápolis

Fachada

A fachada é revestida com azulejos portugueses e ingleses em três padrões diferentes
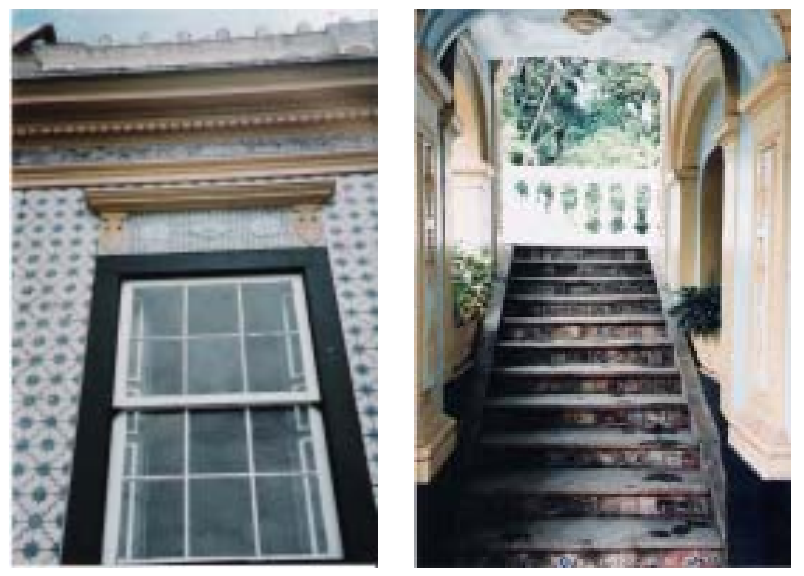

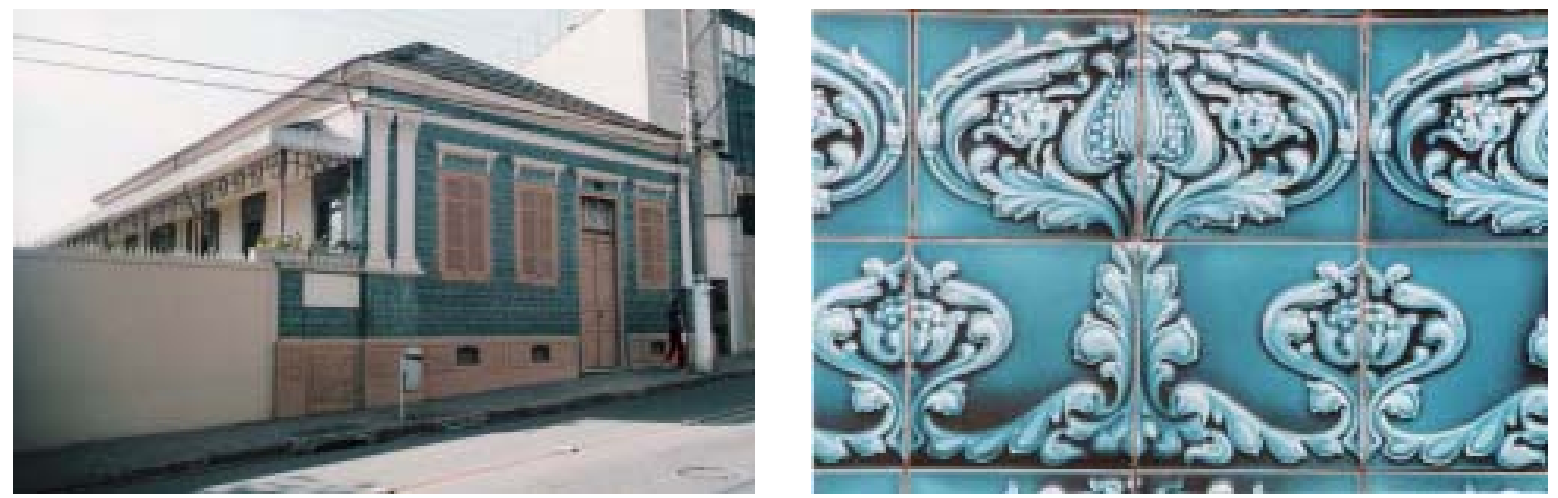

Casa de Azulejo (1889)

Rua, Tiradentes, 211, Limeira

Fachada

A fachada é revestida com azulejos verdes em relevo em dois padrões diferentes cada um com 2 módulos simétricos.
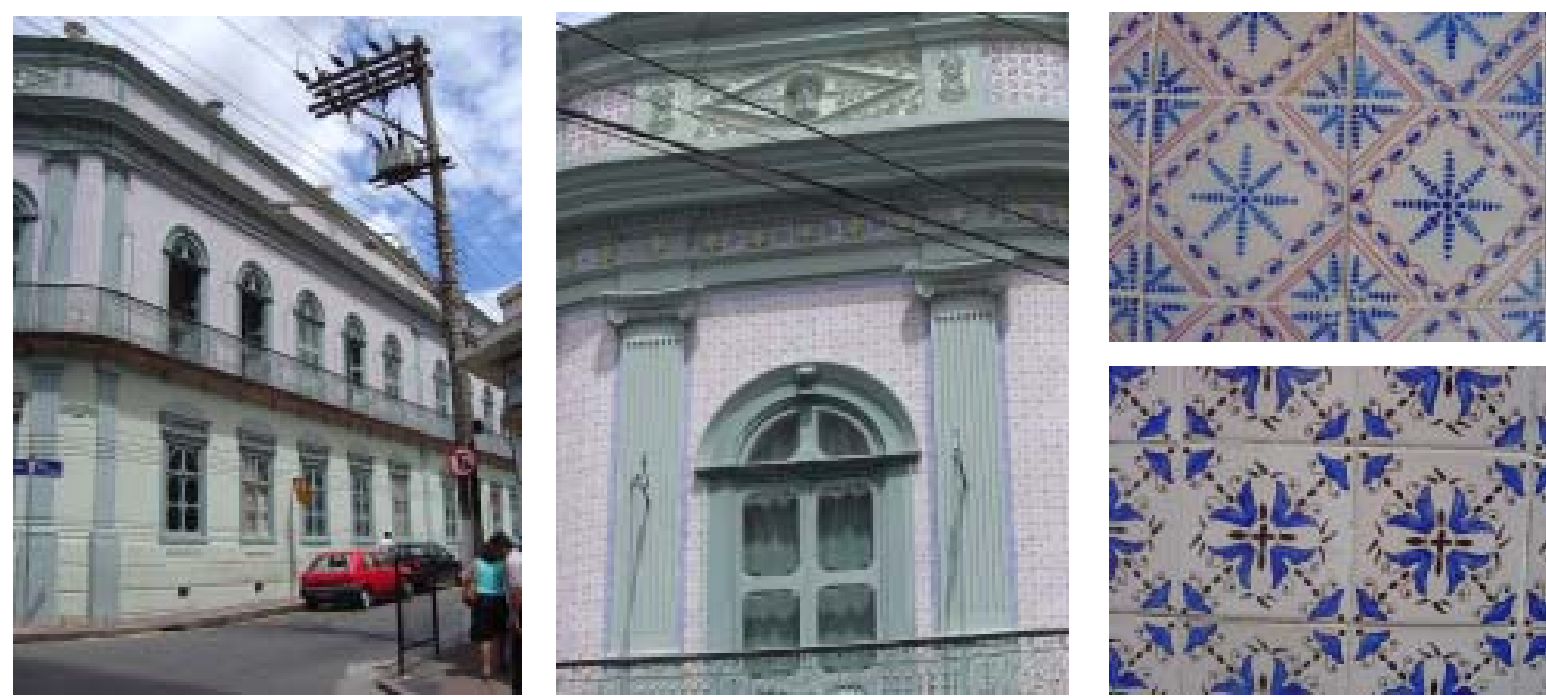

Palácio do Azulejo (1878)

Rua Regente Feijó, no Centro de Campinas

Fachada

As fachadas são revestidas com 2 padrões diferentes de azulejo e um padrão de friso. 0 antigo Solar do Barão de Itatiba (1878), é popularmente conhecido como Palácio dos Azulejos, em razão da fachada revestida de azulejos do Porto, é um dos mais importantes testemunhos da Campinas cafeeira. Caso singular, no século XIX, de duas ricas residências geminadas, 0 edifício foi vendido à Prefeitura de Campinas em 1908, sediando a Sanasa e, atualmente, o Museu da Imagem e do Som. 


\section{apêndice 4 \\ caractarísticas de locais azulejados}

Analisando o levantamento realizado nessa pesquisa foi possível construir o quadro a seguir que pode ser considerado uma amostra onde são relacionados: os tipos de construção onde são usados revestimentos de azulejo, a localização dos azulejos na obra, a variedade de temas, e as cores usadas.

\begin{tabular}{|c|c|c|c|}
\hline tipos de construções & empregos & temas & cores \\
\hline edifícios públicos & $\begin{array}{l}\text { parte da fachada } \\
\text { hall de entrada } \\
\text { muro }\end{array}$ & $\begin{array}{l}\text { específico } \\
\text { com referência a utilização do } \\
\text { edifício (espaço) }\end{array}$ & $\begin{array}{l}\text { azul } \\
\text { branco } \\
\text { várias }\end{array}$ \\
\hline edifícios residenciais & $\begin{array}{l}\text { parte da fachada } \\
\text { hall de entrada }\end{array}$ & $\begin{array}{l}\text { geométricos; } \\
\text { florais; } \\
\text { padrão por módulos }\end{array}$ & $\begin{array}{l}\text { azul } \\
\text { branco } \\
\text { vermelho } \\
\text { amarelo } \\
\text { laranja }\end{array}$ \\
\hline casas & $\begin{array}{l}\text { fachada } \\
\text { parede do terraço }\end{array}$ & $\begin{array}{l}\text { padrão por módulos; } \\
\text { cercaduras; } \\
\text { faixas; } \\
\text { figura avulsa; } \\
\text { geométrico; } \\
\text { floral }\end{array}$ & $\begin{array}{l}\text { azul } \\
\text { branco } \\
\text { vermelho } \\
\text { amarelo } \\
\text { laranja }\end{array}$ \\
\hline igrejas & $\begin{array}{l}\text { frontão da fachada } \\
\text { cobertura de cúpula } \\
\text { altar } \\
\text { paredes laterais }\end{array}$ & $\begin{array}{l}\text { figurativo; } \\
\text { cenas históricas; } \\
\text { cenas do cotidiano }\end{array}$ & $\begin{array}{l}\text { azul } \\
\text { branco }\end{array}$ \\
\hline monumentos & revestimento & $\begin{array}{l}\text { figurativo; } \\
\text { cenas históricas }\end{array}$ & várias \\
\hline fontes públicas & revestimento & $\begin{array}{l}\text { específico } \\
\text { com referência a utilização do } \\
\text { espaço; } \\
\text { brasão }\end{array}$ & $\begin{array}{l}\text { azul } \\
\text { branco }\end{array}$ \\
\hline estações balnearias & revestimento & $\begin{array}{l}\text { específico } \\
\text { com referência a utilização do } \\
\text { espaço }\end{array}$ & $\begin{array}{l}\text { azul } \\
\text { branco }\end{array}$ \\
\hline
\end{tabular}




\section{apêndice 5 glossário}

\section{Azulejo alicatado}

Azulejo hispano-mourisco em que o desenho formado pelo azulejo é englobado na face do ladrilho, dispondo de arestas salientes que impedem a mistura das diferentes cores na cozedura. Revestimento formado por fragmentos de azulejos de diferentes cores, recortados e aplicados em uma composição de arabescos geometrizados, como um mosaico. É o processo mais antigo do azulejo hispano-mourisco. (Fonte: MARCONDES, Luiz Fernado. Dicionário de termos artísticos. Rio de Janeiro: Edições Pinackotheke, 1998.).

\section{Azulejo de aresta ou concha}

Azulejo hispano-mourisco em que o desenho formado pelo azulejo alicatado é englobado na face do ladrilho, dispondo de arestas salientes que impedem a mistura das diferentes cores na cozedura. (Fonte: MARCONDES, Luiz Fernado. Dicionário de termos artísticos. Rio de Janeiro: Edições Pinackotheke, 1998.).

\section{Azulejo de corda seca}

Tipo de azulejo hispano-mourisco, que imita o azulejo alicatado, e no qual as cores são separadas por um filete de pigmento refratário à cozedura, impedindo a sua mistura. (Fonte: MARCONDES, Luiz Fernado. Dicionário de termos artísticos. Rio de Janeiro: Edições Pinackotheke, 1998.).

\section{Azulejo de Tapete}

Tipo de padrão do século XVII, empregado no revestimento monumental da arquitetura religiosa portuguesa e cujo efeito se aproxima daquele obtido com o emprego de tecidos ornamentais. (Fonte: MARCONDES, Luiz Fernado. Dicionário de termos artísticos. Rio de Janeiro: Edições Pinackotheke, 1998.). 


\section{Azulejo de estampilha}

É o azulejo semi-industrial. (Fonte: MARCONDES, Luiz Fernado. Dicionário de termos artísticos. Rio de Janeiro: Edições Pinackotheke, 1998.).

\section{Azulejo de figura avulsa}

Tipo de azulejo que contém uma composição central completa e isolada. (Fonte: MARCONDES, Luiz Fernado. Dicionário de termos artísticos. Rio de Janeiro: Edições Pinackotheke, 1998.).

\section{Azulejo de padrão}

Azulejo com o qual se formam, por multiplicação, figuras repetitivas ligadas. (Fonte: MARCONDES, Luiz Fernado. Dicionário de termos artísticos. Rio de Janeiro: Edições Pinackotheke, 1998.).

\section{Azulejo industrial}

É 0 azulejo fabricado em serie, sendo sua pintura aplicada por processos mecânicos. (Fonte: MARCONDES, Luiz Fernado. Dicionário de termos artísticos. Rio de Janeiro: Edições Pinackotheke, 1998.).

\section{Azulejo semi-industrial}

Azulejo de padrão produzido no século XIX, em que a pintura manual era feita à trincha, através de papel encerado e recortado disposto sobre os azulejos. (Fonte: MARCONDES, Luiz Fernado. Dicionário de termos artísticos. Rio de Janeiro: Edições Pinackotheke, 1998.).

\section{Barra}

Denominação de uma faixa larga pintada. (Fonte: MARCONDES, Luiz Fernado. Dicionário de termos artísticos. Rio de Janeiro: Edições Pinackotheke, 1998.).

\section{Biscoito}

É a peça cerâmica cozida e não vidrada. 


\section{Cercadura}

O mesmo que moldura. Barra que envolve a composição de num mural painel de azulejos, tapeçaria, etc. (Fonte: MARCONDES, Luiz Fernado. Dicionário de termos artísticos. Rio de Janeiro: Edições Pinackotheke, 1998.).

\section{Colorifício}

Fornecedor de matéria-prima cerâmica como fritas, corantes, bases serigráficas, pré-moídos, granilhas, esmaltes e engobes. Além de comercializar estes materiais, oferece aos seus clientes o desenvolvimento de produtos, design e assistência técnica.

\section{Destacamento}

Tipo de patologia que ocorre em revestimentos cerâmicos no qual as peças destacam da superfície. Pode ocorrer em qualquer camada do sistema de revestimento cerâmico, como na alvenaria, chapisco, emboço, argamassa colante ou peça.

Elemento fundente/Fundente. Óxido imprescindível na formulação dos esmaltes. Faz baixar o ponto de fusão de materiais refratários como a sílica que é de $\left(1713^{\circ} \mathrm{C}\right)$ e a alumina. Exceto 0 óxido de chumbo os demais óxidos fundentes funcionam associados com outros da mesma natureza. Cada fundente atua numa determinada faixa de temperatura. Principais fundentes: óxido de sódio, de chumbo, de potássio, de lítio, de cálcio, de zinco, de magnésio, de bário, de boro, de bismuto, de estrôncio. (Fonte: www.ceramicanorio.com).

Elemento opacificador/Opacificante. Material que cria uma barreira impeditiva para a passagem de feixes luminosos. Misturado em esmalte que contenha óxido colorante atua clareando e modificando quase todos os matizes. É sempre uma substância refratária. Principais substâncias opacificantes: óxido de estanho, de zircônio e de titânio. Os óxidos de alumínio, zinco e magnésio atuam como opacificantes se usados em grandes quantidades. O óxido de titânio além de opacificante possui também um caráter colorante podendo produzir tons tostados, amarelados e até azuis. (Fonte: www.ceramicanorio.com). 


\section{Elemento refratário/refratário}

Material com ponto de fusão elevado. (Fonte: www.ceramicanorio.com).

\section{Elemento vítreo}

São os materiais que se fundem durante a queima e, ao se resfriarem, aderem ao corpo cerâmico e dão 0 aspecto brilhante e impermeável do esmalte. A frita (sílica) é um elemento vítreo.

\section{Esmalte}

Vidrado/Glaze. Revestimento impermeabilizante de aspecto semelhante ao vidro resultante da mistura de substâncias minerais que ao se fundirem aderem ao corpo cerâmico de forma definitiva. Podem ser coloridos, transparentes ou opacos. Torna a cerâmica mais resistente. Contém os seguintes elementos básicos: vitrificantes, fundentes, estabilizantes, colorantes e opacificantes. A sílica (quartzo) é o principal material vitrificante e na maioria dos esmaltes chega a constituir, aproximadamente, $50 \%$ da fórmula. Funde em $1710^{\circ} \mathrm{C}$. (Fonte: www.ceramicanorio.com).

Substância vítrea, à base de sílica e de outros óxidos minerais, transparente ou de cores opacas, que é aplicada em superfícies cerâmicas ou metálicas para decoração. (Fonte: MARCONDES, Luiz Fernado. Dicionário de termos artísticos. Rio de Janeiro: Edições Pinackotheke, 1998.).

\section{Estufamento}

Tipo de patologia que ocorre em revestimentos cerâmicos onde as peças, ao aumentarem de tamanho devido à umidade, por exemplo, empurram umas as outras para fora do substrato se desprendendo da superfície.

\section{Friso}

Faixa com ornamentação contínua.

\section{Frita}

Ou vidrado fritado é um vidro moído, fabricado por indústrias especializadas a partir da fusão da mistura de diferentes matérias-primas. É aplicado na superfície do corpo cerâmico que, após a 
queima, adquire aspecto vítreo. Este acabamento tem por finalidade aprimorar a estética, tornar a peça impermeável, aumentar a resistência mecânica e melhorar ou proporcionar outras características.(Fonte: http://www.abceram.org.br).

\section{Gretamento}

Tipo de patologia que ocorre em revestimentos cerâmicos, onde aparecem fissuras (microfissuras parecendo um fio de cabelo, em forma de círculos irregulares ou formando uma teia de aranha) na superfície da peça. Pode ser ocasionada pela má qualidade da peça cerâmica, ou pelas tensões atuantes na peça cerâmica entre base e esmalte após o assentamento, causadas por dilatação térmica ou expansão por umidade.

\section{Lavra}

Procedimento de retirada, extração da matéria-prima natural.

\section{Moagem a úmido}

Processo de moagem onde a matéria-prima é misturada com cerca de $35 \%$ de água, é colocada em moinhos de bolas (seixos) que giram até a obtenção da granulometria e da plasticidade desejada. (Fonte: Sichieri, Eduvaldo.O sistema de revestimento cerâmico.USP/EESC/ArqTeMa).

\section{Moagem a seco}

Processo de moagem realizada em moinhos de martelo com posterior peneiramento.

\section{Moldura}

Tipo de azulejo para dar acabamento nos painéis.

\section{Monoqueima}

Processo em que a peça é queimada uma só vez.

\section{Via seca}

Processo de fabricação de revestimentos cerâmicos que utiliza a moagem a seco. 


\section{Via úmida}

Processo de fabricação de revestimentos cerâmicos que utiliza a moagem a úmido.

\section{Vidrado}

O mesmo que esmalte

Vitrificação. Acontece na queima quando a temperatura atinge o ponto de fusão do esmalte. A superfície da peça fica lisa, impermeável e não porosa. (Fonte: www.ceramicanorio.com). 